\title{
Developing a Biophilic City through Natural Land Transformation Analysis and Geodesign: The case of Purbachal New Town, Bangladesh
}

Udday Shankur Datta

West Virginia University, usd0001@mix.wvu.edu

Follow this and additional works at: https://researchrepository.wvu.edu/etd

Part of the Landscape Architecture Commons, and the Urban, Community and Regional Planning Commons

\section{Recommended Citation}

Datta, Udday Shankur, "Developing a Biophilic City through Natural Land Transformation Analysis and Geodesign: The case of Purbachal New Town, Bangladesh" (2020). Graduate Theses, Dissertations, and Problem Reports. 7697.

https://researchrepository.wvu.edu/etd/7697

This Thesis is protected by copyright and/or related rights. It has been brought to you by the The Research Repository @ WVU with permission from the rights-holder(s). You are free to use this Thesis in any way that is permitted by the copyright and related rights legislation that applies to your use. For other uses you must obtain permission from the rights-holder(s) directly, unless additional rights are indicated by a Creative Commons license in the record and/ or on the work itself. This Thesis has been accepted for inclusion in WVU Graduate Theses, Dissertations, and Problem Reports collection by an authorized administrator of The Research Repository @ WVU. For more information, please contact researchrepository@mail.wvu.edu. 


\section{Developing a Biophilic City through Natural Land Transformation Analysis and Geodesign: The case of Purbachal New Town, Bangladesh}

Udday Shankur Datta

Thesis submitted

To the Davis College of Agriculture, Natural Resources and Design

At West Virginia University

In partial fulfillment of the requirements for the degree of

Master of Landscape Architecture in Landscape Architecture Department

Peter Butler, MLA, Committee Chairperson

Shan Jiang, Ph.D.

Timothy A Warner, Ph.D.

Department of Landscape Architecture

School of Design and Community Development, Division of Resource Management

Morgantown, West Virginia

2020

Keywords: Land transformation, Geodesign, Biophilic design

Copyright 2020 Udday Shankur Datta 


\begin{abstract}
Developing a Biophilic City through Natural Land Transformation Analysis and Geodesign: The case of Purbachal New Town, Bangladesh
\end{abstract}

\author{
Udday Shankur Datta
}

Dhaka, the capital city of Bangladesh is one of the fastest-growing metropolitan regions in the world. To solve the ever-increasing need for housing and to reduce the pressure of the population from the capital city, the Purbachal satellite city was planned. It is the biggest planned township in Bangladesh with an area of over 25 square kilometers. Purbachal is situated at the confluence of the Shitalakhya and Balu rivers. Historically a low-lying wetland, Purbachal has gone through a rapid transformation in past decades. The water bodies around the area have been filled in to create new developable land. Through remote sensing and GIS analysis, this study investigates the transformation of wetland areas in Purbachal New Town.

The study Investigates whether the new developments in the Purbachal New Town followed a natural topography or it was drastically modified from its natural conditions. The study also investigates how these changes in the inherent topographical nature of the area can influence the future of the city. The goal of the study is to explore the complex interrelation of different factors responsible for the growth of a city. The main aim is to formulate a realistic city planning process to synthesize systems city approach with the concept of Biophilic design to create spaces where people will be able to live in harmony with nature. 


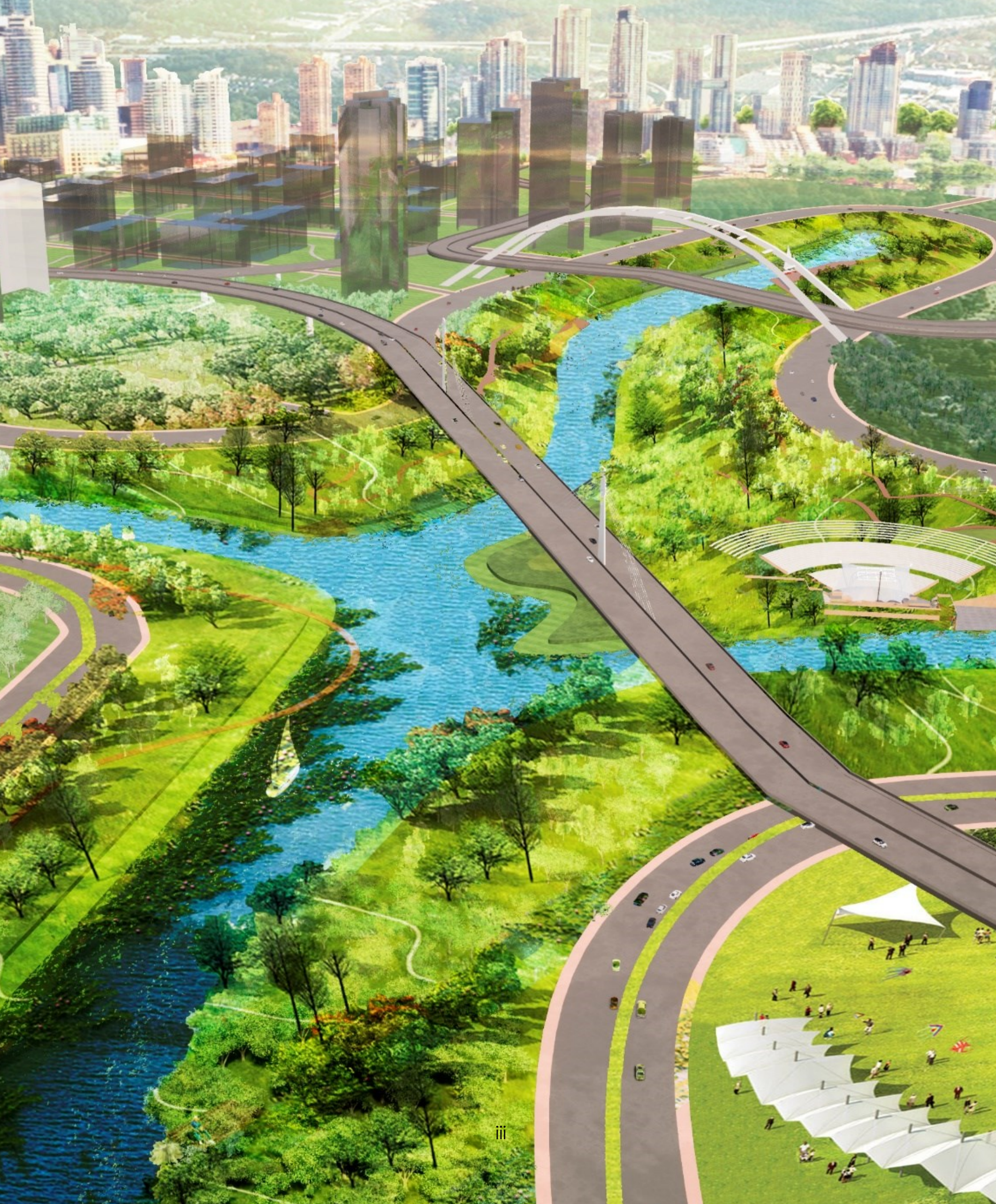




\section{Acknowledgements}

I would like to express my deepest appreciation to my committee members for their advice and support. I would like to extend my deepest gratitude to My advisor and committee chair Peter Butler for believing in me and guiding me in the right direction whenever he thought I needed it.

I am extremely grateful to Dr. Shan Jiang. You were the first person to sit down with me to discuss about my thesis proposal. You raised many valuable points in our discussions and I hope that I have managed to address several of them here. Without your passionate participation and input, the thesis could not have been successfully conducted.

I would like to extend my sincere thanks to Dr. Timothy A Warner for sharing his expertise, and sincere and valuable guidance. You inspired me a lot to gain in-depth knowledge in the field of remote sensing.

I would also like to thank the following people for helping with this research project:

Dr. Michael Strager- For helping me with the analysis process

Dianna Spring- For her motivating words

Ryan Blair and Jesse Jean- For helping me whenever I needed it

A special thanks to my wife Debsree Mandal, who encouraged me to study Landscape Architecture at WVU. Without her motivation, guidance, and relentless sacrifice, I could not even come here and complete my graduation.

Finally, I must express my very profound gratitude to my parents (Alpona Dutta and Uttam Kumar Dutta) for providing me with unfailing support and continuous encouragement throughout my years of study and through the process of researching and writing this thesis. This accomplishment would not have been possible without them. 


\section{Table of Contents}

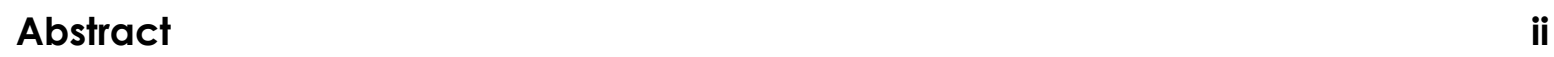

Acknowledgement $\quad$ iv

Table of Contents $\quad$ v

List of Figures $\quad$ vii

$\begin{array}{lll}\text { Chapter } & \text { 1. Introduction } & 1\end{array}$

1.1 Background 1

1.2 Site Location 3

1.3 Scope for New Development 4

1.4 Goals and Objectives 5

1.5 Importance of the Study 6

1.6 Design Concept: Sustainable Urbanism 7

Chapter

2. Research Framework 10

2.1 Research Questions 10

2.2 Methodology 10

2.3 Phases of the Study 11

2.4 Geodesign 13

$\begin{array}{lll}\text { Chapter } & 3 . & \text { Literature Review and Case Studies }\end{array}$

3.1 Literature Review on Remote Sensing 16

3.2 Accuracy assessment 27

3.3 Scope and Limitations of using Remote Sensing 28

3.4 Urban Density/Urban Development 29

3.5 Sustainable Corridor 31

3.6 Sustainable Neighborhood 32

$\begin{array}{lll}3.7 & \text { Biophilia } & 34\end{array}$

$\begin{array}{lll}3.8 & \text { Eco-Urbanism } & 35\end{array}$

3.9 Urban Metabolism 38

3.10 Historical Growth Pattern Analysis 39

3.11 Amsterdam, a Model of City Planning 44

3.12 The development plan for Greater Copenhagen $\quad 47$

3.13 Sustainable planning of Singapore 51 
4. Site Analysis/Geo-analysis 56

4.1 Weather Pattern of Purbachal 56

4.2 Land Transformation of Purbachal 61

4.3 Changing Landform due to Water Level Fluctuation 62

4.4 Unsupervised Classification 63

4.5 Supervised Classification 64

4.6 Water Flow and Watershed Analysis 68

4.7 Digital Elevation Model 69

4.8 Fill DEM $\quad 70$

4.9 Flow Direction 71

4.10 Flow Accumulation 73

4.11 Burn DEM $\quad 75$

4.12 Watershed Map 76

4.13 Results 78

\section{Chapter}

5. Evaluation of Existing Masterplan 80

5.1 Objective of the Existing Masterplan 80

5.2 Major Components of Land Use Plan 80

5.3 Site History and Transformation 83

5.4 Analyzing the Flood Risk 85

5.5 Analyzing Risk from Earthquake 86

5.6 Analysis of Previous Masterplan 87

5.7 Questions for the current development plan 91

5.8 Major drawbacks with the current masterplan 92

Chapter

6. New Masterplan and Design Guideline 94

6.1 Program requirements 94

6.2 Detail Land use plan 97

6.3 Land use Plan Comparison 99

6.4 Design Process 100

6.5 Masterplan Zoning 102

Chapter

7. Detailed Design 104

7.1 Detailed Site Plan 104

7.2 Site 01: Commercial Zone 105

7.3 Site 02: MRT Station 110

7.4 Site 03: Residential Zone 115

Chapter

8. Conclusion 


\section{List of Figures}

Figure

Figure 1.1

Figure 1.2

Figure 1.3

Figure 1.4

Figure 1.5

Figure 1.6

Figure 1.7

Figure 1.8

Figure 1.9

Figure 2.1

Figure 2.2

Figure 2.3

Figure 2.4

Figure 2.5

Figure 3.1

Figure 3.2

Figure 3.3

Figure 3.4

Figure 3.5

Figure 3.6

Figure 3.7

Figure 3.8

Figure 3.9

Figure 3.10

Figure 3.11

Figure 3.12

Figure 3.13

Figure 3.14

Figure 3.15

Figure 3.16

Figure 3.17

Figure 3.18

Figure 3.19

Figure 3.20

Figure 3.21

Figure 3.22
Figure Title

Page

Geographical location of Bangladesh

1

Topography of Dhaka (Source: Google Earth) 2

Chronological development of Dhaka city (Source: Adapted from Urban 3

Planning Department, Dhaka City Corporation, 2007)

Geographical location of Purbachal New Town

4

Land condition of Dhaka metropolitan region (DMR), 2014 (Source: Dhaka 5

structure plan 2016-2035 | Page 159)

Conceptual framework for the research goal 5

Elements of design concept 6

$\begin{array}{ll}\text { Conceptual framework for the research } & 7\end{array}$

Schematic Representation of Design Concepts 8

$\begin{array}{ll}\text { Process diagram } & 10\end{array}$

Conceptual difference between traditional thinking and system thinking 11

$\begin{array}{ll}\text { Flowchart of Research Design } & 12\end{array}$

GeoDesign and planning method (Source: GeoDesign Summit 2011) 13

Geodesign framework (Source: Adopted from Steinitz 2012) 14

Comparison of satellite generations in terms of detail (Kadhim et al., 2016) 28

Adverse effects of automobile-based living community (Source: 29

https://visual.ly/community/Infographics)

Figure 3.3: Comparison between different mode of travel. (Source: 31 http://www.codatu.org)

Sustainability dimensions applied to neighborhoods. (Source: Al-Hagla, 2008) 32

14 Patterns of Biophilic Design 34

Graphic interpretation and summary of Biophilic design elements. 35

(Source: Sayuti et al., 2008)

A Simple Model for Ecological Urbanism. (Source: Living Cities: towards ecological 36 urbanism, Policy Futures Series No. 4/2018)

Shifting City Resource flow. (Source: http://www.iaacblog.com) 38

Historical growth pattern analysis 39

Evolution of a Pre-Industrial City by Karl Gruber $\quad 40$

Modularity from Individual Building to Urban Scale 41

Diagram of Central Place Theory by Walter Christaller 41

Famous Models of Utopian Cities 42

Cellular automata to simulate city growth patterns 42

Stephen Wolfram's A New Kind of Science 43

Patterns of city organization 43

Historic development of Amsterdam $\quad 44$

Connection of Amsterdam with water $\quad 45$

Amsterdam $2040 \quad 46$

Sketch from the first Finger Plan created by the Regional Planning Office in $1947 \quad 48$

Connection of finder plan with water 48

Urban growth of Copenhagen 49 
Figure 3.23

Figure 3.24

Figure 3.25

Figure 4.1

Figure 4.2

Figure 4.3

Figure 4.4

Figure 4.5

Figure 4.6

Figure 4.7

Figure 4.8

Figure 4.9

Figure 4.10

Figure 4.11

Figure 4.12

Figure 4.13

Figure 4.14

Figure 4.15

Figure 4.16

Figure 4.17

Figure 4.18

Figure 4.19

Figure 4.20

Figure 4.21

Figure 4.22

Figure 4.23

Figure 4.24

Figure 4.25

Figure 4.26

Figure 4.27

Figure 4.28

Figure 4.29

Figure 4.30

Figure 4.31
Concept of Copenhagen loop plan

Development concept of Singapore around water catchment zone 52

Land use plan of Singapore 2030

Climatic zones of Bangladesh (Source: Banglapedia, National Encyclopedia of 56 Bangladesh. 2018)

Stereographic Diagram of Purbachal 57

Monthly diurnal average $\quad 57$

Weekly summary of Average Temperature, Direct Solar Radiation, Average 58

Cloud Cover, Average Wind Speed

Prevailing wind in relation with Wind Frequency and Average Relative 59

Humidity

Temperature range chart $\quad 60$

Psychrometric chart $\quad 60$

Land transformation of Purbachal from 2004 to 2019 (image source: LANDSAT, 61

SENTINEL 2)

Transformation of landform due to flooding 62

Area comparison between different types of land form 62

Unsupervised classification of pre-development landform 63

Unsupervised classification of post-development landform 63

Supervised classification of pre-development landform 64

Supervised classification of post-development landform 66

Steps of Watershed Analysis 68

Digital elevation model of Purbachal- $2008 \quad 69$

Digital elevation model of Purbachal- 2015

Concept of Fill sinks (source: https://pro.arcgis.com) 70

Concept of Flow Direction (source: https://pro.arcgis.com) 71

Pre-development flow direction map of Purbachal and surrounding areas $\quad 72$

Post-development flow direction map of Purbachal and surrounding areas $\quad 72$

Concept of Flow Accumulation (source: https://pro.arcgis.com) 73

Pre-development flow accumulation map of Purbachal New Town and 73

surrounding areas

Modified Flow accumulation map of Purbachal New Town and surrounding areas 74

Output of Burn DEM- 2006

Output of Burn DEM- 2015

Watershed boundary (source: https://pro.arcgis.com) 76

The raster representation of the stream network (source: 76 https://pro.arcgis.com)

Pre-development Watershed map of Purbachal New Town and surrounding 77 areas- 2006

Post-development Watershed map of Purbachal New Town and surrounding 77 areas- 2015

Comparison between Pre and Post-development landcover map of 78 Purbachal New Town 
Figure 5.1

Figure 5.2

Figure 5.3

Figure 5.4

Figure 5.5

Figure 5.6

Figure 5.7

Figure 5.8

Figure 5.9

Figure 5.10

Figure 5.11

Figure 5.12

Figure 5.13

Figure 6.1

Figure 6.2

Figure 6.3

Figure 6.4

Figure 6.5

Figure 6.6

Figure 7.1

Figure 7.2

Figure 7.3

Figure 7.4

Figure 7.5

Figure 7.6

Figure 7.7

Figure 7.8

Figure 7.9

Figure 7.10

Figure 7.11

Figure 7.12

Figure 7.13

Figure 7.14

Figure 7.15

Figure 8.1

Landuse plan of Purbachal, 2012 (Source: www.rajuk.gov.bd)

81

Location of open space and waterbodies in the landuse plan of Purbachal, 201282 (Source: www.rajuk.gov.bd)

Geomorphologic map of greater Dhaka city (Source: Geological Survey of 83 Bangladesh, 2014)

Transformation of Purbachal (Google Earth, 2003-2010) 84

Natural topography and current masterplan comparison 84

Inundated Areas in 1998, 2002 and 2004 Floods, Source: (Deveroy S B, 2008.) 85

River flow direction and flood hazard map of greater Dhaka 85

Soil liquefaction susceptibility map of Dhaka (Source: Bangladesh Urban 86 Earthquake Resilience Project)

The Master Plan for Dhaka, 1959 (Source: Adapted from Kabir et al. 2012)

87

Alternatives of Growth Strategy for Urban Expansion in DMAIUDP (Source: Dacca 88

Metropolitan Area Integrated Urban Development Project, 1981)

Dhaka Metropolitan Development Plan 1995-2015 (Source: Prepared by the DHUTS, based on Structure Plan of DMDP, 1995)

Dhaka Structure Plan 2016-2035 (Source: Dhaka structure plan 2016-2035)

89

Range of services and connectivity for strategic centers, (Source: Dhaka structure

plan 2016-2035 | Page 52)

Elements of Biophilic design $\quad 95$

Comparison of Existing and Proposed Masterplan Land Use 98

Land use Plan Comparison 99

$\begin{array}{ll}\text { Design development process } & 100\end{array}$

$\begin{array}{ll}\text { Road network and public transportation } & 101\end{array}$

$\begin{array}{lr}\text { Proposed Masterplan } & 102\end{array}$

$\begin{array}{lr}\text { Detailed Site Plan (1.5 km diameter) } & 104\end{array}$

$\begin{array}{ll}\text { Site 01: Commercial Zone Plan } & 105\end{array}$

$\begin{array}{ll}\text { Site 01: Sections } & 106\end{array}$

$\begin{array}{ll}\text { Relationship of water with urban environment } & 107\end{array}$

$\begin{array}{ll}\text { Characteristics of internal road layout } & 108\end{array}$

$\begin{array}{ll}\text { Cultural hub with open-air amphitheater } & 109\end{array}$

$\begin{array}{ll}\text { Site 02: MRT Station Area Plan } & 110\end{array}$

$\begin{array}{ll}\text { Site 02: Sections } & 111\end{array}$

$\begin{array}{ll}\text { Different modes of transportation } & 112\end{array}$

$\begin{array}{ll}\text { Different modes of transportation } & 113\end{array}$

$\begin{array}{ll}\text { Primary Road detail } & 114\end{array}$

$\begin{array}{ll}\text { Site 03: Residential Zone Plan } & 115\end{array}$

$\begin{array}{ll}\text { Site 03: Sections } & 116\end{array}$

$\begin{array}{ll}\text { Greenery intertwined with the residential zone } & 117\end{array}$

$\begin{array}{ll}\text { High-speed vehicular transportation is discouraged in internal roads } & 118\end{array}$

$\begin{array}{ll}\text { Development with natural harmony } & 120\end{array}$ 


\section{$\alpha 5$}




\section{Chapter 1 Introduction}

\subsection{Background}

Bangladesh is a country in South-Asia located east of India on the Bay of Bengal. Bangladesh is bordered by the Indian states of West Bengal to the west and north, Assam to the north, Meghalaya to the north and northeast, and Tripura and Mizoram to the east, Myanmar to the south east and Bay of Bengal to south. Roughly two-thirds of the country is constituted of deltaic plain of the Padma (Ganges [Ganga]) and Jamuna (Brahmaputra) rivers. The landscape is mostly flat plain surface of recent alluvium, except for small higher areas in the Barind and the Madhupur Tract, respectively. Most of the landscape have a gentle slope with an average elevation of generally less than 30 feet (9 metres) above sea level.

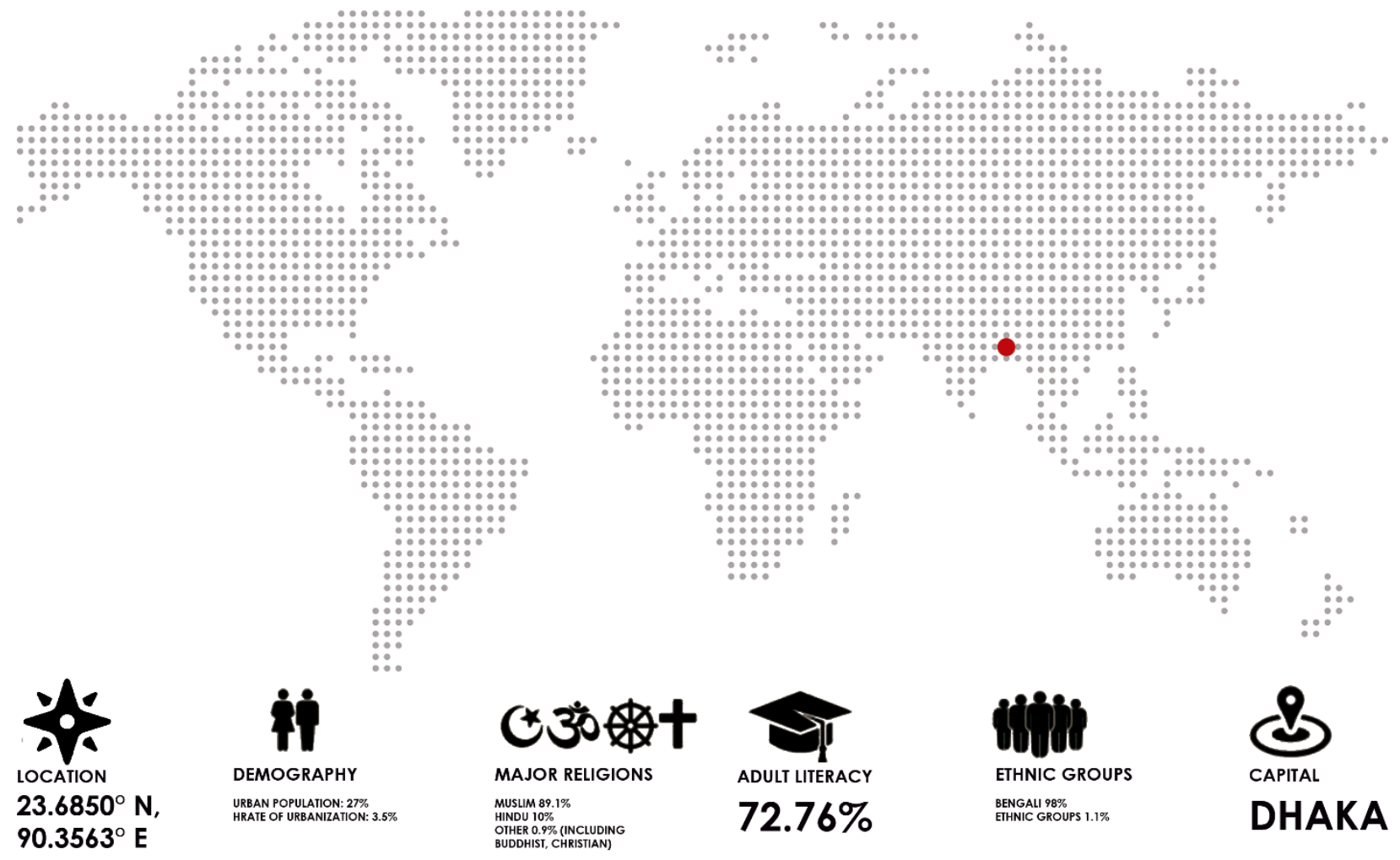

Figure 1.1: Geographical location of Bangladesh (Data Source: BBS 2019)

The riverine country of Bangladesh is the eighth most populated country and one of the most densely populated countries in the world. The people of Bangladesh are predominantly Muslim with Hindu, Buddhist and Christian among major religions practiced in the country. 
The capital city of Bangladesh is Dhaka, one of the fastest-growing metropolitan regions in the world. From a provincial headquarters during the 14th century, Dhaka has gone through a major transformation to become the economic center of Bangladesh. The physical and environmental features largely contributed to the growth of the city (Khan, 2000). But due to the rapid urbanization, human-induced changes have transformed the natural landscape of the city adversely.

The development of Dhaka can be traced back to the 12th century AD (Mowla, 2012). Due to the strategical location to command water routes, the first urbanization of Dhaka started in the Old Natural Levees due to its suitable land elevation (Khan, 2000). In the later period, Dhaka developed gradually. But after independence, rapid unplanned urbanization was followed that resulted in the interruption of the natural drainage system of the city. Being situated on a flat plane, most of the urban areas of Dhaka has an elevation between 6-8m above sea level. Being situated in a subtropical monsoon climate, Dhaka receives around $2,000 \mathrm{~mm}$ of annual rainfall.

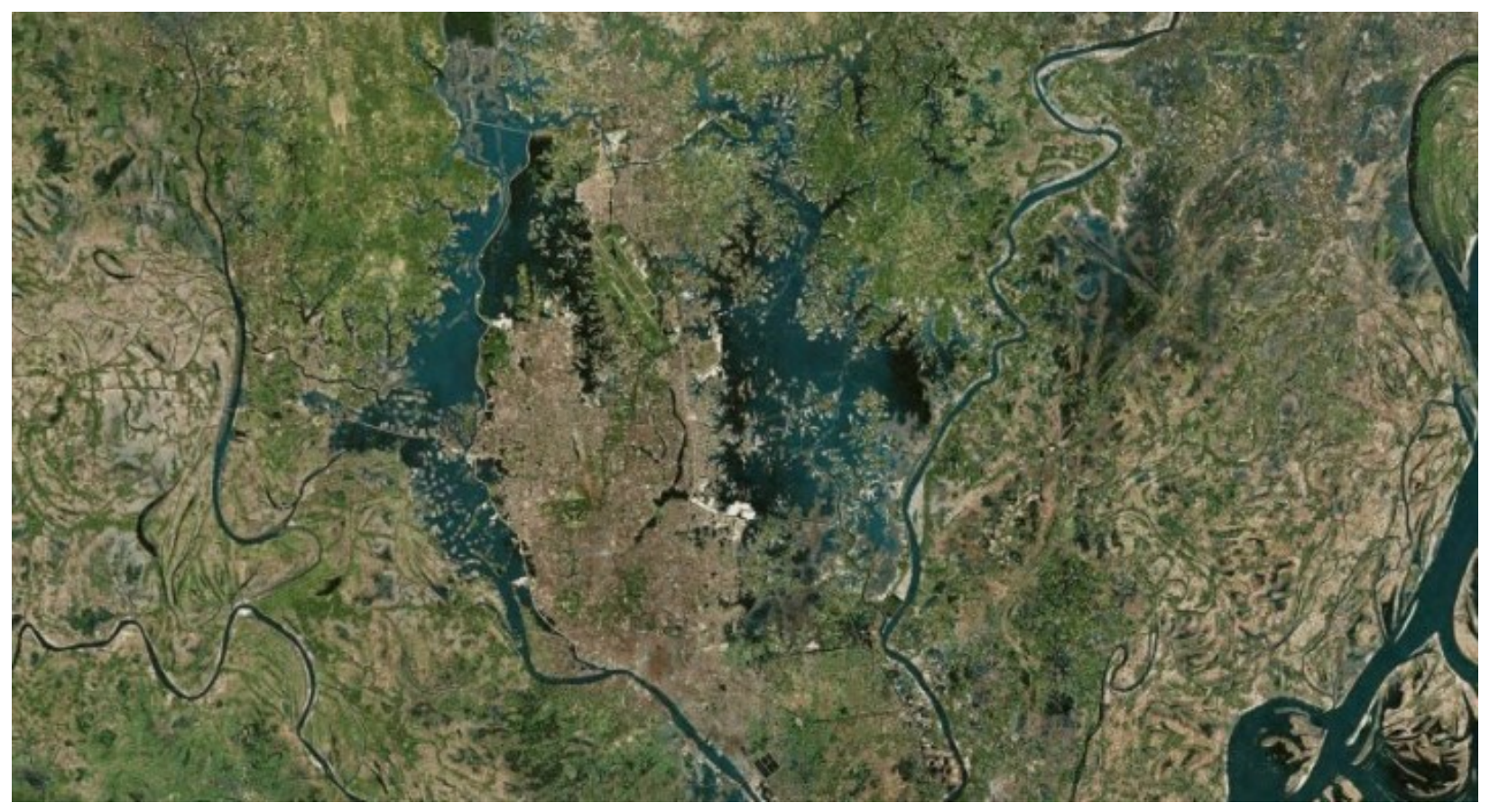

Figure 1.2: Topography of Dhaka (Source: Google Earth)

The rivers, canals, and water bodies used to play a vital role in everyday urban life throughout history (Mowla, 2008). But in recent years the uncontrolled urban development taking place in the low-lying areas made the city vulnerable to urban flooding. Moreover, due to the changing pattern of climate, the chances of extreme rainfall events have increased (Datta et al. 2014). This resulted in a reduced storm lag time and consequently increasing flood peaks (Khan, 2000). 
Dhaka is a low-lying area is surrounded by rivers and flood plains, the amount of developable land in Dhaka city was limited. During the '90s, the city ran out of the land that is suitable for future development. Infill and growth of residential neighborhoods put several infrastructural constrains.

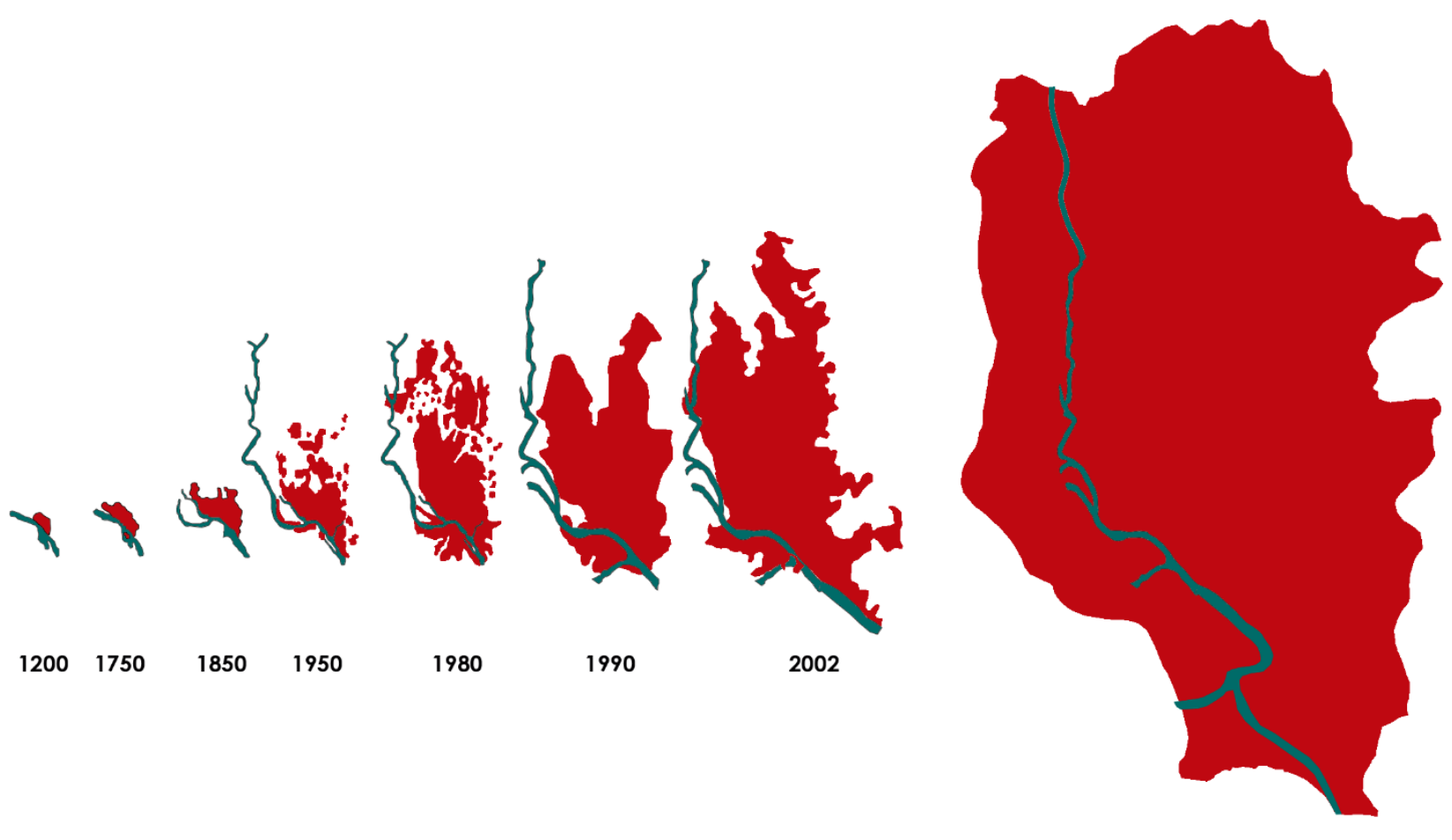

Projected Growth of Dhaka Metropolitan in 2050

Figure 1.3: Chronological development of Dhaka city (Source: Adapted from Urban Planning Department, Dhaka City Corporation, 2007)

To house the ever-increasing population, city authorities started searching solutions in the fringe areas. RAJUK, the Capital Development Authority, was mainly in charge of planning and designing for the satellite towns. In 1995, the plan to develop the largest satellite town in Bangladesh was undertaken. The location was selected at Rupgonj Thana of Narayangonj District and Kaligonj Thana of Gazipur District. The 6150 acres project area was divided into 30 sectors with the 300-meter-wide highway to ensure fast connectivity with the capital city Dhaka. Soon the area once dominated by agricultural landscape started to transform rapidly.

\subsection{Site Location}

Purbachal New Town, is located between $23^{\circ} 49^{\prime} 45.53^{\prime \prime}-23^{\circ} 52^{\prime} 30.72^{\prime \prime} \mathrm{N}$ and $90^{\circ} 28^{\prime}$ $20.18^{\prime \prime}-90^{\circ} 32^{\prime} 43.26^{\prime \prime} \mathrm{E}$. It is around $18 \mathrm{~km}$ away from Dhaka situated in Rupganj Upazila of Narayanganj District and Kaliganj Upazila of Gazipur District. Purbachal New Town is in three administrative districts, Dhaka, Narayanganj and Gazipur. 
Bangladesh is a riverine country and all the major cities, towns and commercial centers are located on the bank of rivers. Purbachal is also not an exception. The area is in eastern-central Bangladesh between large floodplains of Brahmaputra and terraces. The Balu and Sitalakkhya Rivers are on the west and east sides of the new town.

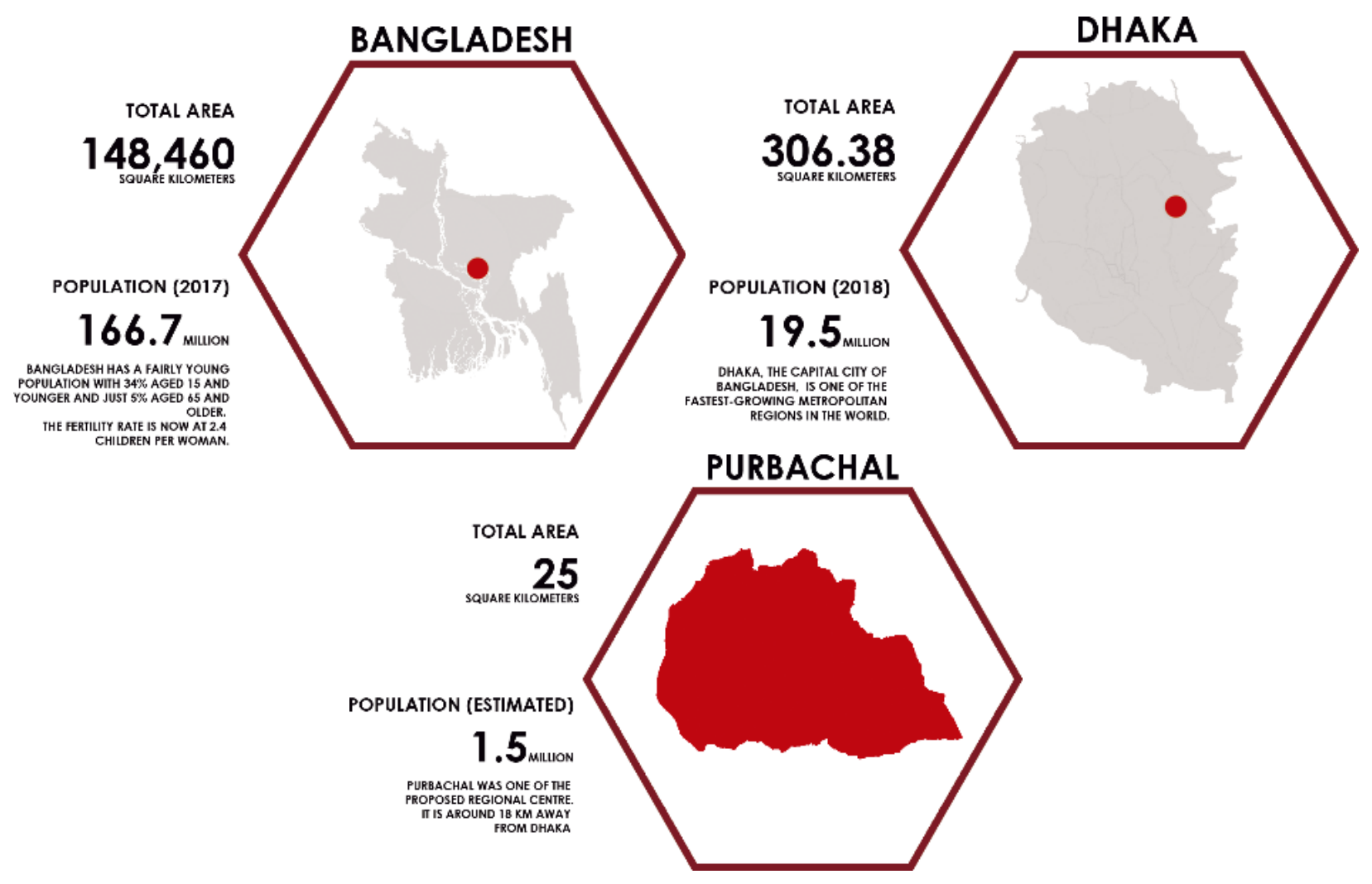

Figure 1.4: Geographical location of Purbachal New Town (Data Source: BBS 2019, www.rajuk.gov.bd)

\subsection{Scope for new development}

Despite being surrounded by low-lying areas, there are lands that can be potentially developed for commercial and residential purposes in Purbachal. From the cross-section elevation of the greater Dhaka region, it can be seen that there are patches of high lands in the Purbachal area where the lands are relatively free from annual flooding and have stable Madhupur Clay where infrastructure will be relatively safe even under the circumstances of an earthquake.

Instead of implementing a superimposed grid system that requires extensive cut and fills to dramatically modify the existing landform, the new town plan should have followed the natural topography by creating a harmonious design that maximizes the use of floodfree lands for residential districts and housing infrastructure, commercial, and administrative districts. Natural low-lying area can server as a buffer to protect the city from annual and major flooding events. 
This type of planning strategy can protect the city from potential flooding as well as preserve the flood flow areas to minimize the flood hazard of Dhaka city which is further downstream. By minimizing cut and fill, the risk of soil liquefaction can also be minimized.

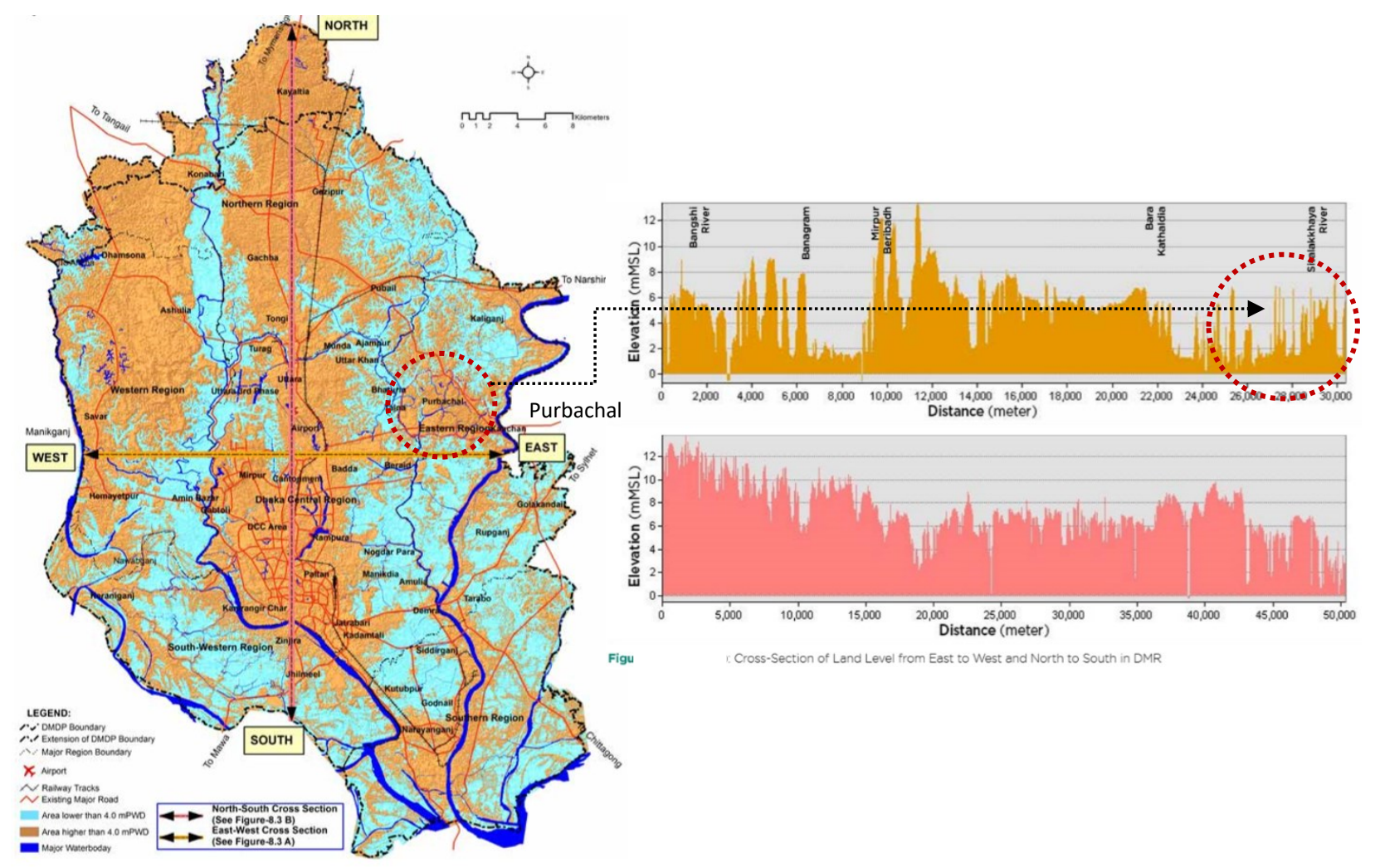

Figure 1.5: Land condition of Dhaka metropolitan region (DMR), 2014 (Source: Dhaka structure plan 2016-2035 | Page 159)

\subsection{Goals and Objectives}

The design aims to create a development plan to that will enhance the economic growth while ensuring the protection of environment to create a sustainable society.

Social improvement:

1. Walkability 2. Connectivity 3. Mixed-use and diversity

Economic improvement:

4. Mixed housing 5. Quality architecture and urban design, 6. Increased density

Environmental improvement:

7. Traditional neighborhood structure 8. Green transportation 9. Sustainability 10. Quality of Life

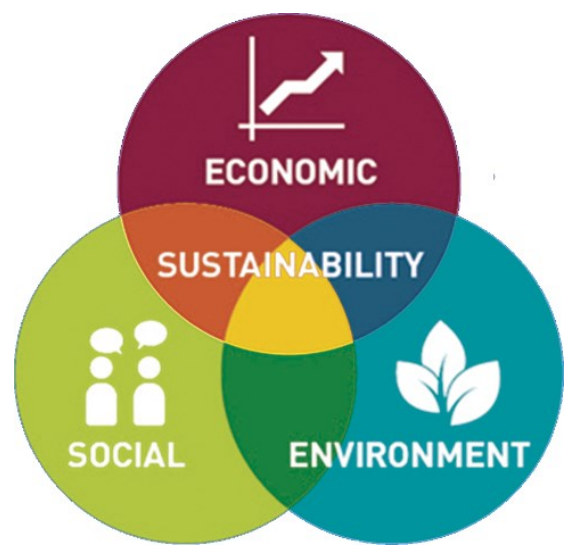

Figure 1.6: Conceptual framework for the research goal 
Objective 1: Identification of natural land transformation pattern

Objective 2: Analyze the impact of anthropogenic disturbance of natural landscape

Objective 3: Development of a matrix in accordance with natural landform to guide development strategies

Objective 4: Propose new urban green infrastructures to promote Biophilic design

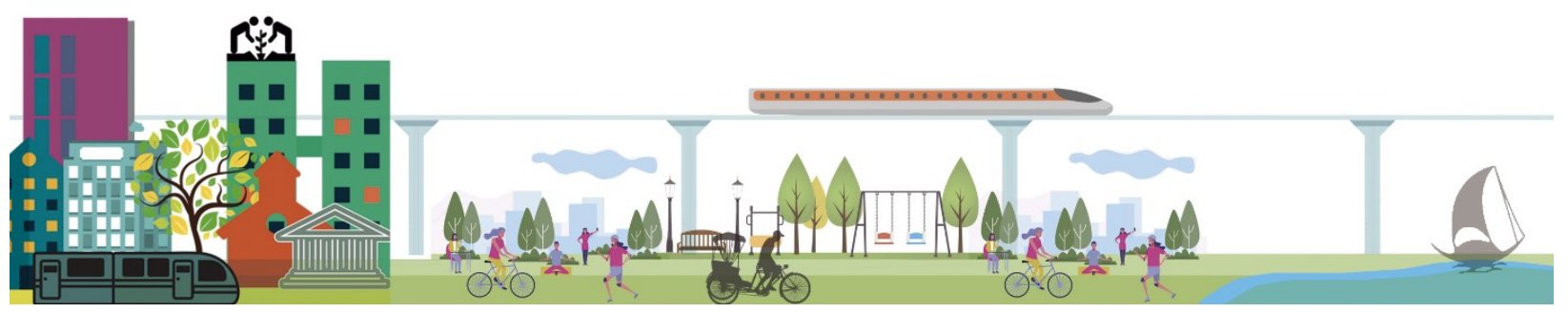

Figure 1.7: Elements of design concept

\subsection{Importance of The Research}

More than half of the world's population now live in cities, making humanity a predominantly urban species for the first time in its history. Today, over 4 billion people around the world - more than half the global population - live in cities. This trend is expected to continue. By 2050, with the urban population more than doubling its current size, nearly 7 of 10 people in the world will live in cities (Cohen, 2003). As the urban population expected to grow in the upcoming years, it is important to develop sustainable development strategies to make the future cities an environment friendly setting. The impact of cities on the world's resources is, in fact, disproportionate to their share of the population. Urban activities are estimated to account for some $67 \%$ of total energy consumption, and $70 \%$ of greenhouse gas emissions (OECD/IEA 2008).

Similar dominance of the global demand for resources can be observed in urban consumption of freshwater, wood and other raw materials. Cities around the world are struggling to provide resources to sustain the huge influx of urban population. Therefore, cities should develop sustainable planning strategies to meet this ever-growing demand of resources. This is much more important in the case of developing countries like Bangladesh. So, it is vital to develop planning strategies based on the understanding of natural landscape patterns. By integrating natural ecosystem with urban planning, the future cities will be able better equipped to face the challenges of climate change. The future cities should not fight with the natural adversaries to survive, but it should generate a collaborative understanding with natural elements. 


\subsection{Design Concept: Sustainable Urbanism}

- To increase the percentage of the green area by promoting green building concept.

- To ensure a fair percentage of greenery is present in the newly developed areas.

- To develop a detailed Landscape master plan integrated with the Utilities Master Plan and Transportation Master plans.

- To develop a detailed framework of the transportation prioritizing public transport with a bicycle lane and pedestrian-friendly road network.

- To develop design guidelines to keep the river at both sides of the Purbachal New Town pollution free.

- Planning for vertical development rather high-density horizontal development.

- Promotes connections with natural elements to create a biophilic city.

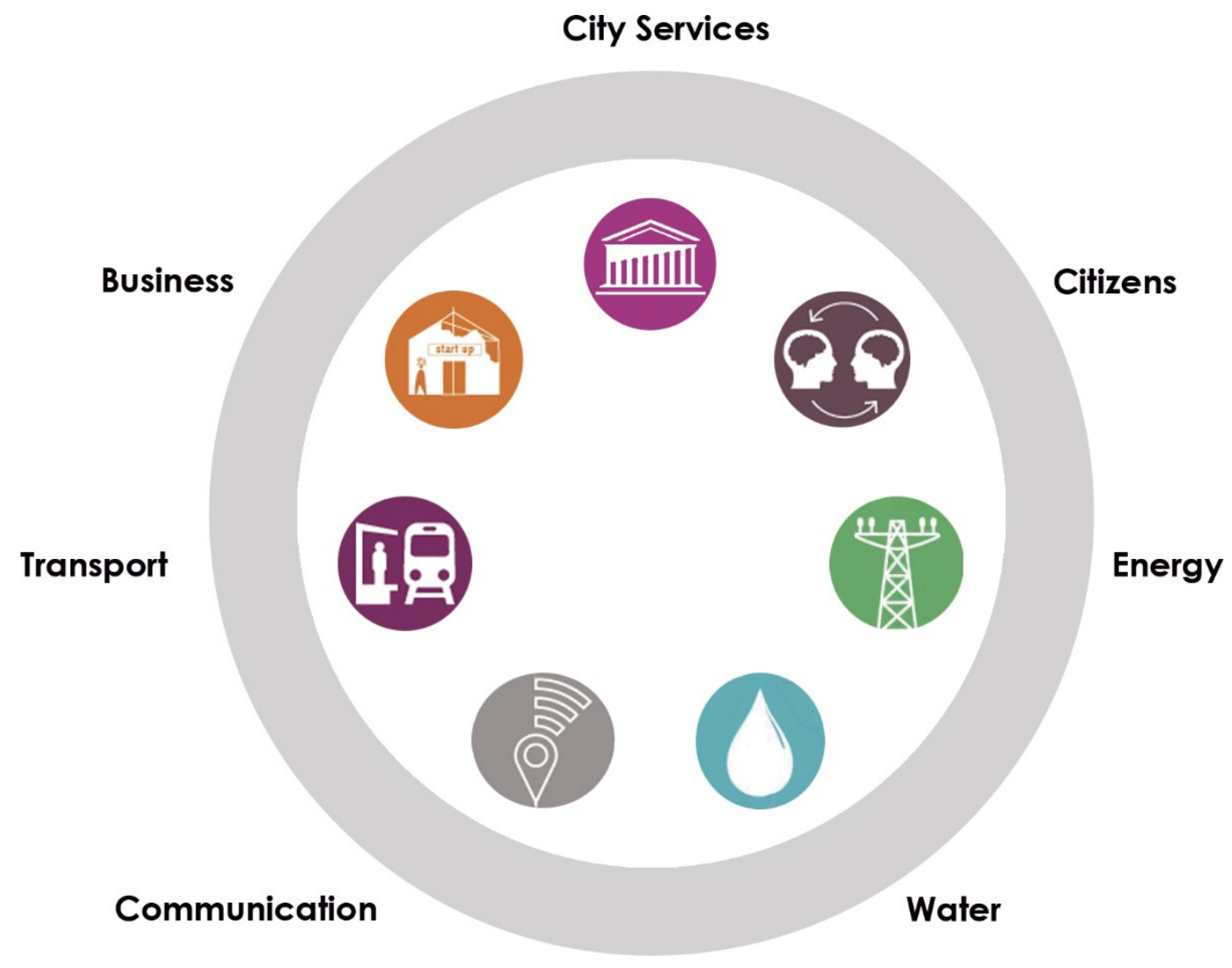

Figure 1.8: Conceptual framework for the research 
The development plan comprises the following strategies:

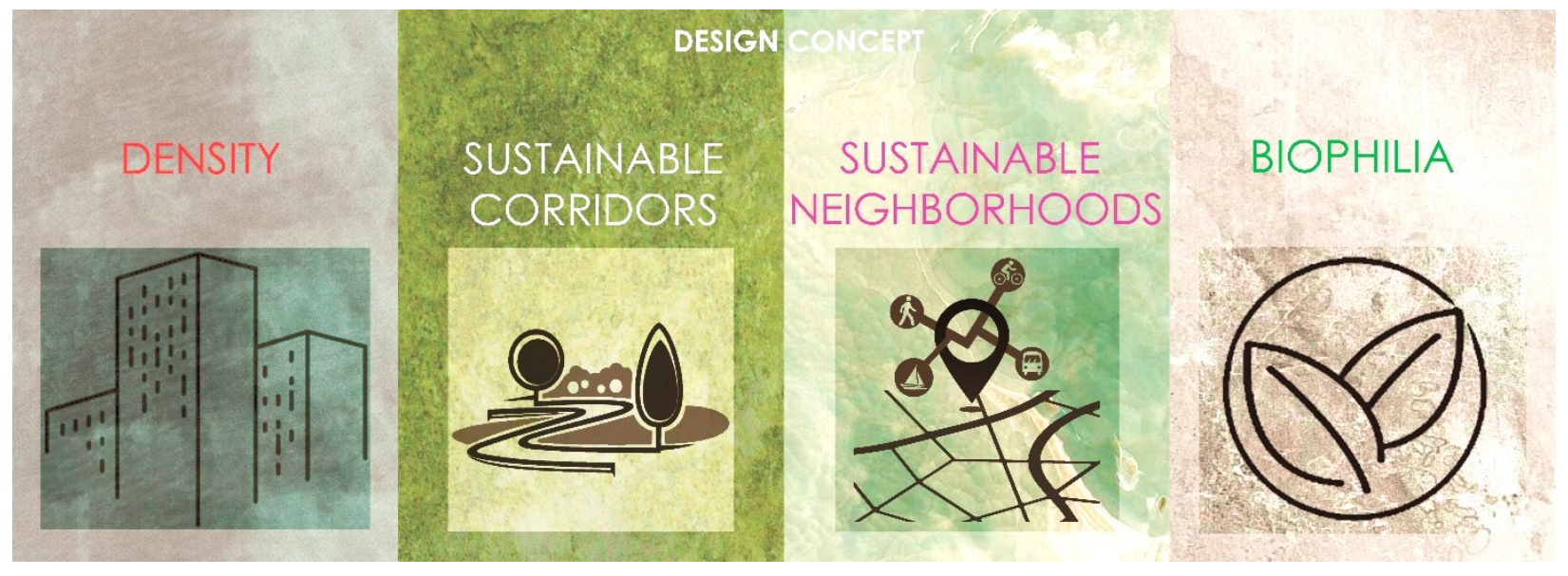

Figure 1.9: Schematic Representation of Design Concepts

\section{DENSITY}

To reduce energy consumption and increase transportation efficiency, the Masterplan proposed new dense urban development strategies prioritizing vertical development rather than high-density horizontal development.

\section{SUSTAINABLE CORRIDORS}

The project develops a detailed Landscape plan integrated with the Utilities Master Plan and Transportation Master plans. To discourage the use of the automobile, small scale plazas were designed around the transit hubs. To increase the percentage of the green area, the design implemented the green building concept to ensure the percentage of per capita greenery remains between 9.6 to $4.6 \mathrm{~m} 2$ present in the newly developed areas.

\section{SUSTAINABLE NEIGHBORHOODS}

To ensure a high-quality lifestyle for the city dwellers, the new plan prioritized cyclists and pedestrians by providing less space for motorized traffic within the city. To mitigate the impact of global warming and minimize the risk of urban flooding, the plan included a network of canals placed throughout the city. Using green roofs would act as a rainwater collector to prevent localized or widespread flooding.

\section{BIOPHILIA}

The design promotes connections with natural elements to create a biophilic city. Water has been an intricate part of the life of the people of Bangladesh. The plan proposes to incorporate greenery intertwined with the vast networks of the waterway and make them accessible for recreational purposes. The wetland will support an incredible range of flora and fauna and create a natural habitat for local species. 



\section{Chapter 2 Research Framework}

\subsection{Research Questions}

1. To what extent the new masterplan has modified the area and the surroundings from its natural conditions?

2. How the modified landscape will shape the future urban growth pattern?

3. How will changing the relationship between natural factors affect the future urban environment of Purbachal?

4. Is there a way to develop the area without hampering the natural landform pattern?

5. Is it possible to re-establish the deep structures inherent in the landscape to strengthen the relationship between the natural factors?

\subsection{Methodology}

To study the adverse effect of human-induced land transformation, many researchers have used Remote Sensing (RS) techniques to trace the transformation pattern of a city from pre-urbanization periods to the current situation.

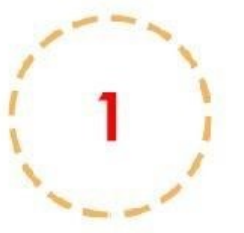

Remote sensing

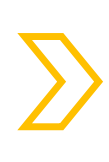

Impact assessment

a. Flood assessment

b.Slope analysis

c.Watershed analysis

d.Permeability analysis

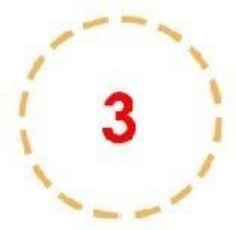

\section{Strategy development}

a. System Thinking

b. Land transformation

c. Biophilic design

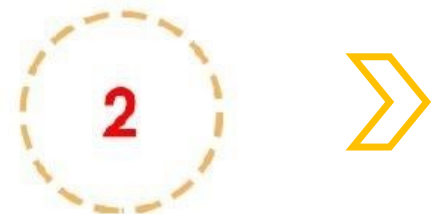

a. Data accusation

b. Classification

d. Accuracy test

Figure 2.1: Process diagram 
Every city has a deep structure or enduring context. As we modify and change the ecosystem, the natural state of the landscape is altered to a hybrid state. The success or failure of any city can be traced back to the alternating pattern of this inherent structure. This research aims to study the complex "network structure" that plays a vital role in the development and growth of a city and to promote human interactions in urban ecosystems. The study will try to find this connection and create a development strategy that will be interlinked with the natural processes of the landscape.

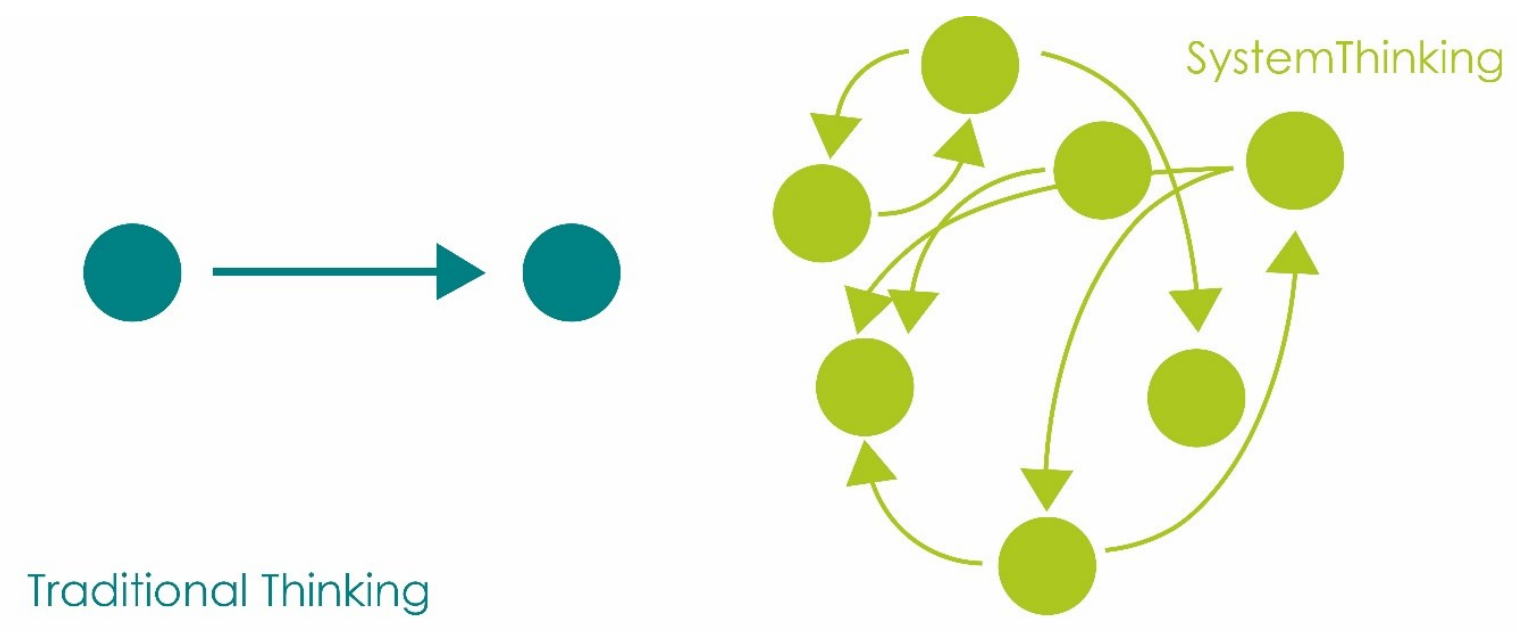

Figure 2.2: Conceptual difference between traditional thinking and system thinking

\subsection{Phases of the Study}

The study aims to develop a comprehensive design strategy that uses Geodesign tools with the concept of Biophilia to create a resilient city. Geodesign provides the framework for exploring issues from an interdisciplinary point of view. While Biophilic design strategies address the innate biological connection with nature for humankind. The project combines these two concepts to develop a framework for intelligent, holistic geospatial design.

The study was divided into four main phases:

1. Geo-analysis: In the first phase, the changing urban land use and land cover (LULC) conditions of the region was analyzed to understand the geo-spatial structure of the region.

2. Evaluation of existing masterplan: In the second phase, performance of existing masterplan of Purbachal was evaluated and potential consequences of the intervention was discussed.

3. Developing guidelines for new masterplan: In the third stage, new design guidelines were developed based on the Geo-analysis to create a holistic design strategy.

4. Site design and details: Finally, detailed design solutions for different section of the masterplan was developed. 


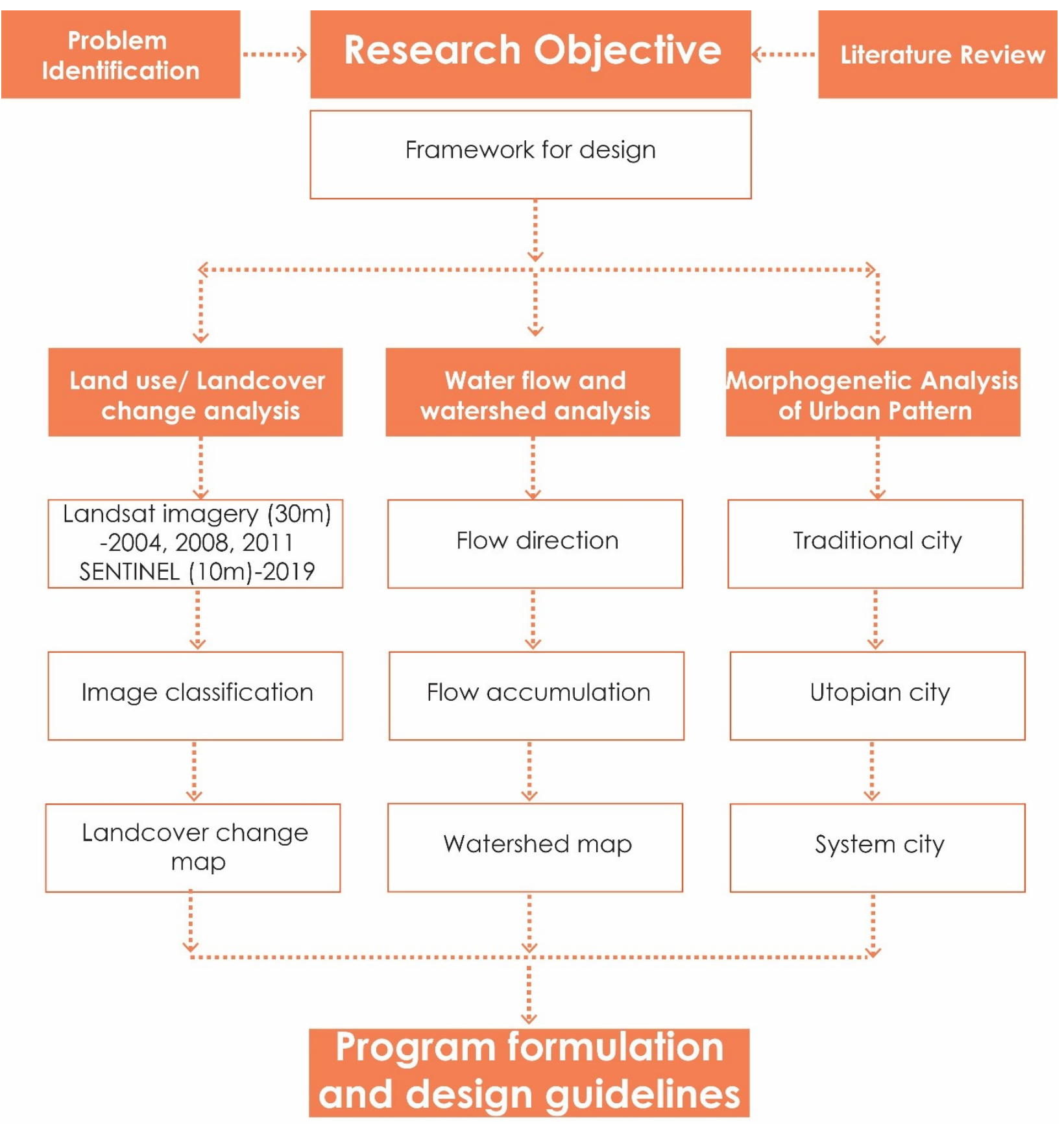

Figure 2.3: Flowchart of Research Design

The flowchart (Figure 2.3) summarizes the process of developing the new design. Through remote sensing, the pre and post-development character of the landscape will be analyzed. Image classification techniques will be used to produce land cover maps to compare the changes that took place during the last 20 years. These maps will be useful to identify the areas that remain flood free during a major flood event and can be developed in the future. 
In the next phase, the hydrology of the area will be analyzed. Using the Digital Elevation Model (DEM), the flow of water stream was analyzed to create pre and postdevelopment watershed map to see how the land modification altered the natural hydrology.

In the third stage, the morphogenic analysis was conducted to find out the growth characteristics of cities and how cities have evolved in different ages. The study then focused on three specific cities to see how the planning process of these cities was guided by the natural features. The study also focused on how the concept of biophilia and Transit-Oriented Development were incorporated with the design process.

\subsection{Geodesign}

\section{"Design is the thought process comprising the creation of an entity" (Miller 2005).}

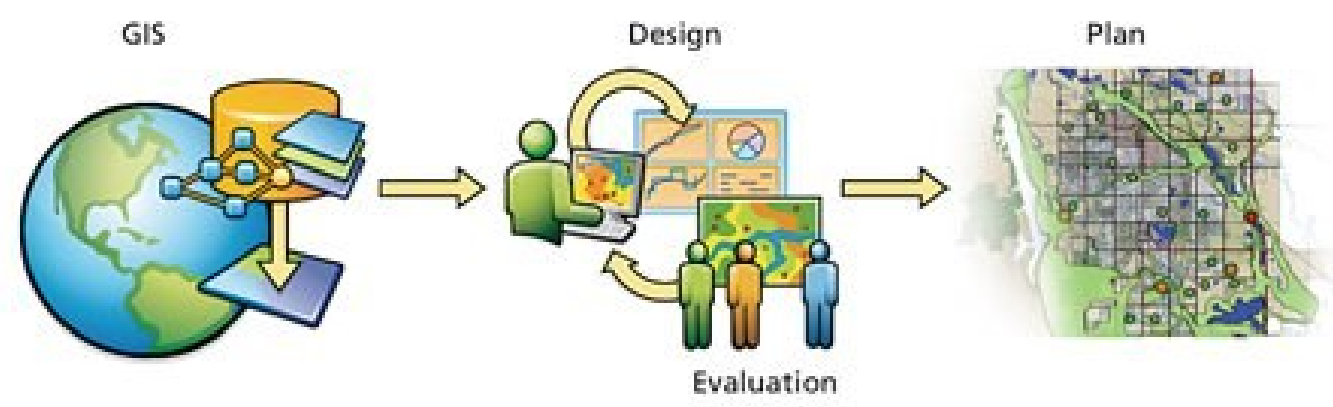

Figure 2.4: GeoDesign and planning method (Source: GeoDesign Summit 2011)

The concept underpinning Geodesign derives from the study of Patrick Geddes and Ian McHarg in the early half of the 20th century. They advocated a layered approach to site design, landscape and urban design. McHarg arranged these layers as translucent overlays. Through the study of Jack Dangermond, Carl Steinitz, Henk Scholten and others, Geographical Information System (GIS) was developed. Geodesign combines geography with design by providing designers with robust tools that support the rapid evaluation of design alternatives against the impacts of those designs.

The Geodesign process combines a process that uses geographical information to guide towards a smart design. By combining geospatial modeling with impact simulation, Geodesign process creates a feedback process that facilitates holistic design. Through contextual analysis, Geodesign can evaluate future possible outcomes for different design strategies and guide the designer towards a sustainable solution. By brings geographic analysis into any design process, Geodesign can follow the natural systems closely to generate design solution that is harmonious with nature. 
Carl Steinitz developed a complete conceptual framework, design strategies, and procedural techniques for doing Geodesign that can be applied to regional landscape studies. The Geodesign framework uses six models to describe the Geodesign planning process.

The first three models comprise the assessment process. These models analyze the existing conditions within the geographic context. The potential consequences of the intervention process are analyzed by the last three models. These processes determine whether the context should be modified or kept same as the existing condition.

This planning strategy can protect the city from potential flooding and preserve the flood flow areas to minimize the flood hazard of Dhaka city, which is further downstream. By minimizing cut and fill, the risk of soil liquefaction can also be minimized.

1 How should the landscape be described?

How does the landscape
operate?

3 Is the landscape working well?

\section{How might the landscape be altered?}

\section{What differences might the changes cause?}

\section{Should the landscape 0 be changed?}

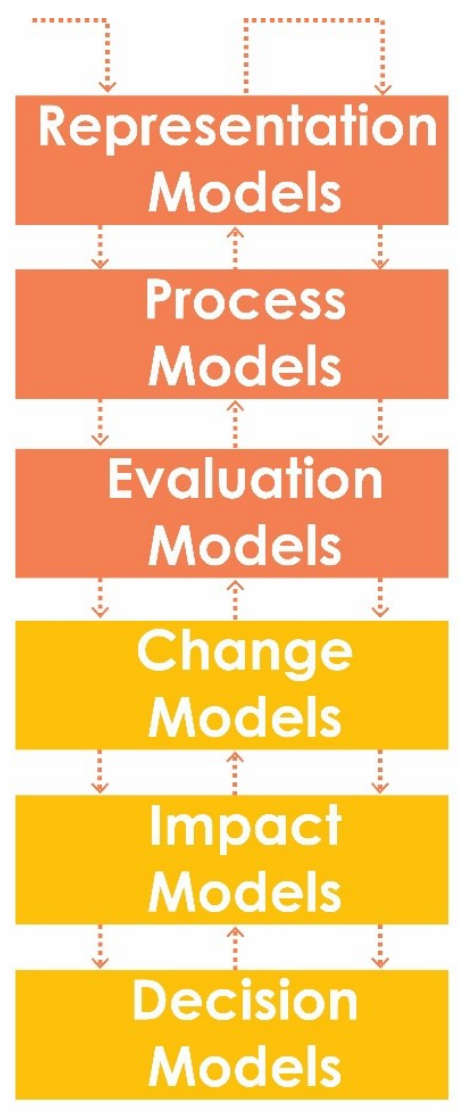

Data

Information

Knowledge

Data

Information

Knowledge

Figure 2.5: Geodesign framework (Source: Adopted from Steinitz 2012)

The project aims to develop a comprehensive design strategy that uses Geodesign tools with the concept of Biophilia to create a resilient city. Geodesign provides the framework for exploring issues from an interdisciplinary point of view. While Biophilic design strategies address the innate biological connection with nature for humankind. The project combines these two concepts to develop a framework for intelligent, holistic geospatial design. 


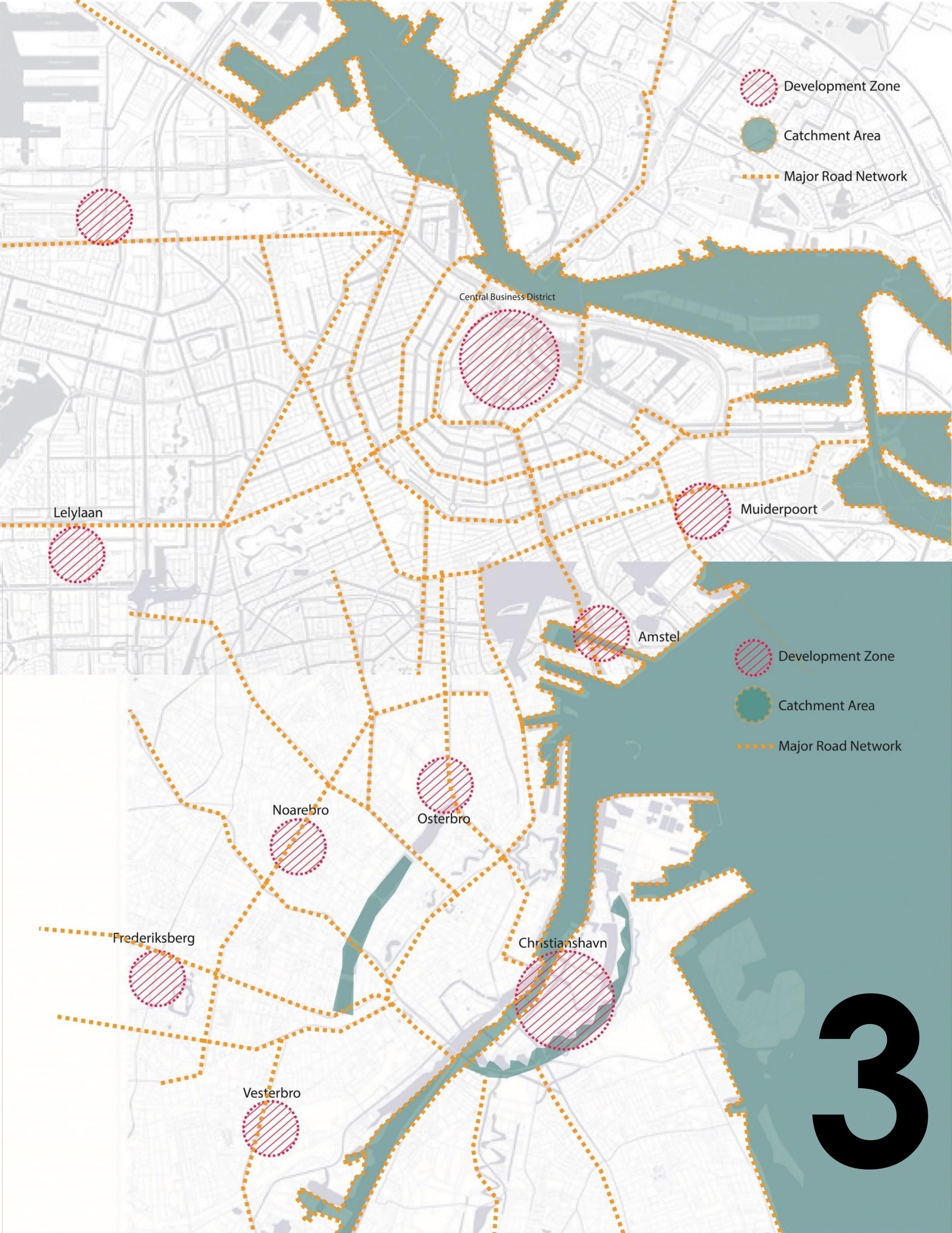




\section{Chapter 3 Literature Review and Case Studies}

\subsection{Literature Review on Remote Sensing}

\section{1-1 Derivation of Land Cover Maps}

The main source used in producing land use map was Landsat images. Ahmed et al. (2013) mainly used Landsat images acquired from 1989, 1999, and 2009. On the other hand, Dewan \& Yamaguchi (2009) and Khan (2000) used a combination of Landsat images with SPOT and aerial photography to compare pre and post land development typologies. Landsat MMS band 7 (0.8-1.1 um) is found particularly useful to analyze the flood delineation, but some studies also suggested using TM band 7 with Band 4 in combination (Dewan \& Yamaguchi 2009).

Zhu et al (2012) test the effectiveness of combining radar and optical data to map different land cover categories. The hypothesis behind the study is although the nonparametric classification methods have improved the level of accuracy in remote sensing classification, the accuracy is still low for urban environment when compared with forest and grasslands. To improve the accuracy of landcover classification, the researchers combined multi-season Landsat Enhanced Thematic Mapper Plus (ETM+), single-season Advanced Land Observing Satellite (ALOS) and Phased Array type L-band Synthetic Aperture Radar (PALSAR) data and mapped 17 land cover categories of the Greater Boston area for urban and pre-urban environment and analyze how the process changed the overall map accuracy.

For the study, a 12,404 km2 area with diverse land cover types on the eastern side of Massachusetts was selected. Mainly 3 types of the dataset were used for the study, Landsat data, PALSAR data and Ground reference data. Four Landsat ETM+ images from four seasons (autumn, winter, spring, and summer) between 2000-2002 were used as multitemporal inputs. Atmosphere correction tools were used to reduce the atmospheric effects and pixels containing clouds or shadows were excluded. The PALSAR data used were of Fine Beam Dual (FBD) mode acquired from American ALOS data node and processed with the Woods Hole Image Processing System (WHIPS). A final mosaic of 24bit GEO TIFF image was created with nine ALOS PALSAR scenes from June and July 2007 with a $15 \mathrm{~m}$ pixel resolution. With the aerial photographs and fieldwork done between 20052007, a Ground data set were created with a resolution of approximately $45 \mathrm{~cm}$. To 
test the influence of different input variables, land cover maps of the study area were created. A Random Forest Classifier (RFC) was used for mapping to reduce the complexity as there are only two input parameters. Among all data used, $80 \%$ were randomly selected to train the classifier and the remaining $20 \%$ data were used to assess map accuracy. A total of 8 different scenarios were tested to find how each process changed the level of accuracy. The process was repeated 50 times for a different combination of input data and results were plotted on a confusion matrix for all 17 land cover categories.

The results from the confusion matrix indicate that the inclusion of more dimensions of input data and more sensors that complement each other improved the land cover classification accuracy. Although the addition of PALSAR data increased the accuracy only by $1.1 \%$ (mostly improving the three urban land cover types), it was a statically significant increase as the overall map accuracy of $93.82 \%$ was achieved by this combination of PALSAR and Landsat data. After evaluating different dimensions of the input data, it was determined that additional spatial dimensions of PALSAR data improved the overall classification accuracy.

By combining Lidar and PALSAR data a higher accuracy level can be achieved in urban land cover classification especially in urban conditions. However, as the researchers indicated, the level of accuracy varies with the number of variables and different dimensions of input data. The study area for the research by Zhu et al (2012) was relatively a flat terrain, it will be interesting to see how the results differ if the same techniques were applied in the context of flat terrains and climatic conditions of Bangladesh.

\section{1-2 Data classification}

The statistical characterizations were followed by Digitization of the training sites (Ahmed et al. 2013). Maximum likelihood classification method was commonly used. Dewan \& Yamaguchi used supervised Maximum likelihood classification method. No training data used had pixel size less than 280 and the greatest pixel size used was 7800 . Mixed pixel was faced as a common problem due to the heterogenous nature of the urban land cover.

In the study by Weng (2012) finds the effectiveness of different method of digital remote sensing to extract and estimate information regarding impervious surface. For every type of urban development and resource management project, it is vital to have impervious surface data. In the field of water management and water quality analysis, imperviousness surface data is important to determine the amount of direct water runoff, source of pollutants and toxic contamination. The ever-increasing amount of impervious surface is directly influencing in-stream and riparian habitats and has been linked to the loss of some critical aquatic habitat. Therefore, it is crucial to estimate and map impervious surface to assess the impact of human-environment interaction. Impact of 
major types of approach like pixel-based, sub-pixel based, object-oriented algorithms and artificial natural methods were analyzed through literature review related to impervious surface identification. The author discusses about the major techniques of impervious surface classification and how the integration of hyperspectral image and LiDAR data is changing the research trends. For the study, the author mainly focused on three techniques of impervious surface detection, data/image fusion, expert system and contextual classification methods. Yearly publication trend related to each trend was analyzed from 1991 to 2000 indexed by Scopus. A total number of 184 articles including journal articles were reviewed. The publications were analyzed for the types of data used for the study and to find out the trends in impervious surface identification techniques.

The results show that existing literatures have regarded impervious surface mostly as a type of material, land cover or land use. There has been a great interest for mapping urban landscape in various scales. On the other hand, research interest to find out about the spectral, geometrical and temporal properties of impervious surface has been relatively low. A major reason behind this trend has been the type of data used for the research as a major part of the reviewed literature used imagery of medium resolution (10-100 m). The author also points out how the research trend has been different among the scholars in Europe, Asia and North America. The author also finds important change in trend with the use of high-resolution satellite imagery in research. Due to the availability of a wide range of data from LiDAR, the use of feature extraction methods was widely applied when they were used for the research instead of medium resolution imagery.

Because most of the past remote sensing studies related to impervious surface have used medium resolution images, the research methods, models and research interest was greatly influenced by the image resolution. With the advent of high spatial images like LiDAR, new models and algorithms have been generated to make the best use of this valuable data. As a result, new trends like attribute analysis and information extraction by ANN models, object-based image analysis and enhanced urban mapping via data and image fusion has been on the rise. Several new studies combining contextual texture and spatial information have been observed with the integration of high spatial images.

The availability of new tools and techniques always plays vital role to change the trend specially in the field of research and studies. With the availability of high spatial images like LiDAR, the research related to impervious surface has seen a major shift in terms of subject topic and methodology used for the study. However, as the author points out, research in different part of the world has shown different trends, perhaps since many nations in Asia or Africa do not have the same level of access to high spatial images sources. As the use of high spatial images becomes more common, we can hope that many more new trends and collaborative study patterns will immerge from the integration of this powerful research tool. If high spatial images or LiDAR data can be obtained for the Purbachal New Town, the data classification can be improved a lot. 


\section{1-3 Data Analysis}

Wilson et al (2003) tests how satellite imagery can contribute to evaluate environmental impacts of different zoning in urban areas. To control the extent of development in urban areas, planners use zoning laws to impose restriction on variables such as building height, density etc. The relationship of zoning and its impact on urban environment plays crucial role in urban planning. By evaluating the existing zoning conditions can provide valuable insights for the future decision making. The researchers used moderate spatial resolution satellite images to evaluate the influence of zoning on Normalized Difference Vegetation Index (NDVI) and Radiant Surface Temperature (Ts) in the city of Indianapolis, USA.

The study was conducted in three phases. The first phase how NVDI and Ts measurements can be used to differentiate between different types of zoning was examined. Secondly, the relationship between NVDI and Ts values for the city and within different zoning categories was analyzed. And finally, how zoning rules influenced the local environment were analyzed. Landsat 7 ETM+ images from path 021, row 032 from June 2000 was used for the study purpose. As the primary data source used for the study was radiant surface temperature and vegetation, only the images under relatively clear sky condition were acquired. With the US Geological Survey's Earth Resource Observation Systems (EROS) Data Center the acquired images were processed to make corrections for radiometric and geometric distortions. The images were georeferenced to Universal Transverse Mercator coordinate system, Zone 16 North. Then additional spatial data depicting spatial attributes of different zones were added by using GIS polygon layers. The zoning attributes were combined into two broader categories: general zoning categories and detailed categories.

The analysis was carried out in four stages. First the visual interpretation of NVDI and Ts imagery was conducted. Then the relationship between NVDI and Ts values for different in the study region was categorized according to zones. Then how different zoning categories were differentiated by comparing relationship of NVDI and Ts data by multiple comparisons of means. And finally, the relationship between NVDI and Ts was recorded in a scatter plot for 6462 zoning polygons in the study regions. The result suggests an inverse relationship between Ts and NVDI in the study area. Different types of zoning showed significantly different effects on radiant surface temperature.

The study was conducted by using moderate spatial resolution satellite images which had a major impact on the result. A higher resolution imagery could have been more useful to study specific urban regions with greater details. The study method used can be implemented to evaluate other forms of landscape and urban design considerations. The research is particularly useful to measure environmental consequences of existing zoning policies in order to develop strategies for future development. 
Shao et al (2003) explores the effects of impervious surface in altering urban hydro environment. Due to rapid urbanization, growth of impervious surface area (ISA) has become the main reason behind increased rate of urban flooding around the world. New development strategies like Low Impact Development (LID) has been developed to manage urban storm water by mimicking the pre-development hydrologic condition. Two major challenges have been identified by the researchers in current research and application of urban hydrological research. The first is hydrological models being developed by following multi-level administrative units rather than watersheds. Another problem is urban watersheds system not being studied dynamically by considering adjacent watersheds. To address these issues, researchers proposed a multi-level watersheds runoff monitoring model that explore the impervious surface changes by using Landsat images with Google Earth Engine (GEE).

The results show direct relationship between larger peak discharge and increase of impervious surface ratio. But in some watersheds, the runoff was less than the expected rate even when the ISA ratios for those watershed areas were between $60-90 \%$. This establishes the hypothesis that runoff is not only related to the proportion of the impervious surface but also related to the area.

The study puts emphasis on the fact that urban hydrological modeling should be addressed differently than conventional method. As the city has different factors influencing the nature of water discharge and water flow, a multi-level watersheds runoff monitoring model can provide a better understanding of the water dynamics which can be useful in analyzing urban hydrology.

The methodology used in these studies by Wilson et al (2003) was very interesting as this method can be useful for other urban design evaluation. The main limitation of the study was it calculated the impact of Radiant Surface Temperature therefore the study is limited only to temperate and tropical climates. Perhaps now with better resolution image and new data from Landsat 8, the relationship between design strategies and resulted environmental impact can be studied more precisely.

The study by Shao et al (2003) takes a new look on the process of urban hydrological evaluation. It was interesting to see how dynamics of urban environment can influence urban hydrology. The paper however does not describe the city layout and topographical features in detail which could have provided a better explanation behind the water runoff changes. It will be interesting to see the process being implemented in different context to find out about the effectiveness of the method. 


\section{1-4 Data Analysis in the context of Bangladesh}

Dewan et al (2009) assesses impact of rapid urbanization on land use/cover changes in the Greater Dhaka region of Bangladesh. Anthropogenic causes have been the main driving factor for natural habitat destructions around the world. With the increasing population and rapid urbanization, cities in developing world are facing the worst impact of changes in urban land use and land cover (LULC). With the use of Geographic Information System (GIS) and Remote Sensing (RS), the researchers developed an algorithm to evaluate the spatial and temporal dynamics of LULC.

The capital city of Bangladesh, Dhaka was selected as the study area. The city is going through rapid urbanization process and is expected to become the third largest city in the world by 2020. To support huge influx of migrating people, the city has grown exponentially by infilling low-lying areas and clearing vegetation. To assess the changing LULC conditions of Greater Dhaka region, Landsat data (MSS, TM and ETM+) images from 1975 to 2003 were analyzed. With fieldwork data collected from 200 reference points by using a global positioning system (GPS), a ground truth map was prepared. A supervised maximum likelihood classification (MLC) algorithm was used for satellite image classification. Due to lack of high-resolution images, mixed pixilation was a common problem faced by the researchers. Rule-based techniques using thematic information and GIS data were used to improve the accuracy of MLC. The accuracy of LULC data derived from Landsat was between $85-90 \%$. In addition, land survey data and SPOT Pan images and socio-economic data acquired during 1973-2003 were used to develop pre and post development maps. With the rule-based post-classification refinements the map accuracy was further improved.

With the LULC change pattern analysis, it was observed that housing development has been the major driving force in the development of Dhaka. Most of the development were done on ad hoc basis without any major plan. Connectivity played an important role in the growth pattern as the construction of bridge and new roads accelerated urban expansion. GIS analysis revealed that water bodies and wetlands have been the main victim of rapid urbanization. The overall built-up area increased rapidly by $37.9 \%$ between 1992 to 2003. The study suggest that physical settings and topography had main influence in growth pattern. Location of four major rivers and low lands were the first target of expanding housing sectors which resulted in rapid loss of urban wetland and waterbodies in the city. The study has a limitation in detailed analysis as high-resolution data was not available. The researchers have shown how the remote sensing techniques can play vital role in understanding the dynamics of rapid urbanization in developing world. It also gives a relative low-cost alternative for the planners and policy maker who wants to create future planning for an ever-changing city and wat to get a better understanding of the dynamics of LULC. 


\section{1-5 Predicting the future urban growth pattern}

Ahmed et al (2012) in their research predicts the future urban growth pattern of Dhaka, the capital city of Bangladesh by analyzing Landsat satellite images. Dhaka has seen a rapid urban development due to exponential population growth in recent years. Most of this rapid urbanization has been the result of spontaneous developments to house the huge influx of population migrating from rural areas. The main objective of the paper is to predict the future growth pattern of the city by developing a Multi-Layer Perceptron Markov (MLP_Markov) model.

The study mainly consists of two parts, developing a base map by following a fisher supervised classification and simulating different models to come up with the best suited model for the prediction. Landsat satellite images from Path 137 Row 44 for the year 1989, 1999 and 2009 were used to develop a base map with five types of landcover.

Google earth images and the detail land use map (2009) of Dhaka were also used to further verify the classification. To generalize the fisher classified land cover, $3 \times 3$ mode filter was applied to remove isolated pixels. Accuracy Assessment were done of the land cover maps for the year 1989, 1999 and 2009 and an overall accuracy of $85.20 \%, 86.80 \%$ and $91.60 \%$ respectively was observed. The errors in the maps were $14.8 \%, 13.2 \%$ and $8.4 \%$ for 1989, 1999 and 2009 which was not much greater than the amount of land cover change during those years.

Based on the land cover maps, Stochastic Markov (St_Markov) Model, Cellular Automata Markov (CA_Markov) Model and Multi-Layer Perceptron Markov (MLP_Markov) Model were developed. After comparing the results, MLP_Markov 2009 model showed the lowest percentages of disagreement (28.066\%) and highest percentages of agreement components $(71.934 \%)$ and therefore selected as the model to predict the land cover map for the year of 2019 of Dhaka City.

The results showed that $58 \%$ of the total study area will be converted to built-up area and the water body (6\%) and fallow land (11\%) showed the greatest amount of decrease. The error in the base map preparation stage was greater than the apparent change in land cover which can be developed further to generate a more accurate future prediction. The researchers expected that this process can be followed to develop sustainable urban development strategies in future.

As with many RS studies conducted for this region, availability of high-resolution data was a major problem. Images with higher spatial resolution from IKONOS, QuickBird or other satellite might have played vital role in improving the study model. 


\section{1-6 Analyzing the anthropogenic transformation}

Khan, N. I. (2000) used the temporal map and database to analyze the anthropogenic transformation of the Dhaka Metropolitan Area (DMA). The city has gone through a high rate of human-induced land transformation due to unplanned urbanization which in turn obstructed the natural drainage system by reducing water caring capacity. The author combined temporal mapping techniques using Geographic Information System (GIS) and combined it with Remote Sensing (RS) data to create a database showing the transformation of DMA from 1608 to 1996.

The historic maps and dataset were analyzed using visual and automated interpretation techniques to identify built-up areas. Aerial photograph from 1955,1975 and 1983 was used with SPOT PAN, TM (FCC) and IRS-1C PAN images to examine the impact of urbanization on the surface water system. GIS was used to combine maps from 1955 to 1996. The study used Linear regression technique was used to predict future urban landform transformation pattern.

The results show that due to the strategical location to command water routes, the first urbanization of Dhaka started in the Old Natural Levees due to its suitable land elevation. In the later period, Dhaka developed gradually. Due to its high elevation, most of the urbanization took place in the flood free Madhupur Terrace. But after independence, rapid unplanned urbanization was followed that resulted in the deterioration of the natural drainage system of the city. As most of the urban growth was horizontal development, the city started to expand towards depressed areas and abandoned channels surrounding the Madhupur Terrace. These low-lying areas were not geologically suitable for urbanization. But in recent years the uncontrolled urban development taking place in the low-lying areas made the city vulnerable to urban flooding. This resulted in a reduced storm lag time and consequently increasing flood peaks.

By combining historic maps with recent satellite images, the study showed the urban development trends of the DMA. The study provided insight into future development and can be used to develop predictive modeling techniques to analyze future growth patterns.

With historical maps, the author mainly used visual interpretation techniques to analyze the maps. However, the process of integrating the historical map with GIS is not well explained. The study was more focused on the obtained results rather than the process which will be a limitation in using this study in other areas. Although the study mainly focused on quantifying the data, the idea of combining historical maps with aerial imagery and satellite image can be developed further to use it in other contexts. 


\section{1-7 Classifying and mapping recent land cover changes}

Isunju et al (2016) in their research classified and mapped recent land cover changes in the Nakivubo wetland from 2002 to 2014 . The research used very high-resolution aerial photos with satellite imagery to analyze the reasons of wetland encroachment. The negative impact on the local communities resulted from wetland encroachment was also analyzed and provided guidelines to protect the wetland and the communities depended on the wetland.

The study site was Nakivubo wetland which is the central wastewater drainage system for Kampala, the capital city of Uganda. The $5.29 \mathrm{~km} 2$ wetland serves as a catchment area of over $50 \mathrm{~km} 2$. The wetland is located within the equatorial belt zone characterized by a bi-annual rainy season. As a result, only part of the wetland remains permanently inundated. The seasonal dry areas are naturally dominated by grassland which has gone through major transformation in past decades. Due to rapid urbanization in the surrounding areas, the wetland is getting converted into crop fields. To map the transformation, high resolution $(0.50 \mathrm{~m})$ aerial photographs, Quickbird images $(0.62 \mathrm{~m})$ and Pleiades image $(0.50 \mathrm{~m})$ were used. The image data was complemented with key informant interviews (Klls) with stakeholders and focus group discussions (FGDs). All satellite images were pan-sharpened, and terrain corrected. Object based classification method was used to identify seven prominent landcover types in the study area. Each image was segmented in eCognition 9.0 to correspond to unique image features. Support vector machine (SVM) classifier was used with Normalized Difference Vegetation Index (NDVI). Confusion matrix was generated for each classification. The results showed above $83 \%$ of overall accuracy with Kappa statistics between 0.89-0.80. The total areas of different land cover class were later calculated by using ArcGIS.

The results showed the wetland vegetation decreased by $62 \%$ between the year 20022014 mainly due to crop cultivation. The researchers predicted that the loss of wetland vegetation will have adverse effect on the water quality. The increased human activity also increased the risk of flooding. The researchers proposed to clearly identify the wetland areas to protect them from encroachments to restrict increasing agricultural activities to protect the wetland-dependent communities.

The paper gives a different perspective of how wetlands are facing threats from agricultural conversion. It also gives insights on how quickly the wetlands are getting converted into different types of land use. One major limitation of the study was the aerial photographs and satellite images were not from same season which affected the mapping of certain land covers. As the aerial photographs did not had Near Infrared (NIR) band, NDVI could not be calculated from those photographs. The study has put a lot of emphasis on generating accuracy statement which can be useful for my future studies. 


\section{1-8 Assessing flood hazard conditions}

Dewan et al (2007) in their research assessed the flood hazard conditions of Dhaka, the capital city of Bangladesh by using Synthetic Aperture Radar (SAR) data in combination with GIS data. From multi-date SAR imageries, the researchers assessed the flood hazard by using the ranking matrix in three-dimensional multiplication mode. The new flood hazard map developed by the researchers aim to provide a comprehensive guideline for developing future flood prevention plan for the city.

The Six RADARSAT SAR (Narrow and Wide Beam mode) images from the flood season of the year 1998 were used for the study. The SAR images were suppressed and geometrically corrected by using a referenced Landsat image of the year 1999. After applying a second-order polynomial fit, new resampled pixel values were obtained where the ground resolution was $50 \mathrm{~m}$ for narrow and $100 \mathrm{~m}$ for wide beam mode. A digital elevation model (DEM) obtained from the Institute of Water Modelling (IWM) was used to generate an elevation map. All topographic and land cover maps were integrated with geometrically corrected SAR images within a GIS system. With the data, flood-affected frequency map with four flood frequency categories was developed to identify the inundated areas during the 1998 flood. To estimate the depth of floodwater during this time, Multi-temporal SAR images were used by following a technique suggested by Islam and Sado (2000) for the greater Dhaka. The developed maps were compared with related studies conducted by IWM to check for accuracy.

The Flood-affected frequency and floodwater depth maps were superimposed by using ERDAS IMAGINE software. With the help of land cover data and elevation height, percentage of flood-affected areas were calculated. A weighted score was assigned to the different typed of flood depth for each land cover category. By using a linear interpolation method, flood hazard scores between 0 to 10 were assigned to different areas. The resulting map was reclassified according to the intensity of hazards. The resulted maps show that $28.70 \%$ of the area was under very high hazards and $26.56 \%$ area was under high hazard zones in the city. Due to the high-density development in the lowlands and river banks, the city is highly susceptible to flooding.

The study predicted that many areas within the moderate to very high hazard zone are the fringe areas that will be urbanized in near future. These areas will be more vulnerable for future flooding and flood remediation plans should be developed for these areas to minimize the impact of any future flooding.

Although the process described in the study is not widely used to produce flood hazard maps, the use of RS in flood hazard assessment has a lot of potentials. Urban planners and policymakers can get useful information for developing future development plans with this process. The availability of DEM and SAR image is a major factor for the successful implementation of this technique in any future studies. 


\section{1-9 Performance evaluation of different hydraulic models}

Ali et al (2015) made comparisons of different 1-D hydraulic models developed from various digital elevation models (DEM) sources. The study evaluated the performance of the hydraulic models in simulating flood water levels to demonstrate how using different DEMs can influence the results. The researchers also performed an uncertainty analysis to explore the sensitivity of different hydraulic models to different DEMs.

For any flood modeling, topographic data such as DEMs are a crucial element. Researchers can collect the data from various sources such as through remote sensing (RS) techniques or ground-based surveys. Depending on the source, the precision and accuracy of a DEM can differ a lot. For example, low-cost DEMs from satellite imagery like ASTER and SRTM have a coarse resolution between 30-90 m, while more expensive techniques like Lidar can generate $1 \mathrm{~m}$ resolution DEM which is very high resolution. Through a ground survey, more accurate data can be generated, but it is more time consuming compared to other sources. The researchers used different DEMs to predict the flood water level of Johor River, in Malaysia to analyze the impact of various DEMs on the predicted outcome.

For the study, the researchers used model code HEC-RAS for Flood inundation modeling developed by the Hydrologic Engineering Center (HEC), USA. The study used eight digital elevation models from $1 \mathrm{~m}$ to $90 \mathrm{~m}$ resolution as topographical input. To calibrate and validate the models, flood data of e Johor River in 2006 and 2007 were used.

From the results, it was observed that $1 \mathrm{~m}$ DEM from Lidar Data produced the most accurate model. When the model used lower resolution DEMs produced from deducting the resolution of lidar DEMs (from 1 to $90 \mathrm{~m}$ ), the model still performed relatively well. But when other sources of coarse DEM were used for the model, the percentage of errors increased. It was concluded that the model based on ASTER data completely failed because of inaccuracies of the DEM, on the other hand, DEMs from SRTM data and topographic contour maps gave an acceptable result.

The outcome of the study was not counterintuitive as the DEM having the highest spatial resolution produced the best model. But it was also interesting to see how the different resolutions changed the outcome of the model. Although, lower resolution DEMs had more errors, but the model produced from $30 \mathrm{~m}$ DEM produced a relatively accurate result ( $1 \mathrm{~m}$ DEM model had an accuracy of $96.6 \%$ while $1 \mathrm{~m}$ DEM model had an accuracy of $92.2 \%$ ), therefore DEMs from SRTM data and topographic contour maps gives an acceptable result when used in largescale flood modeling. 


\subsection{Accuracy assessment}

Accuracy assessment is perhaps the most important part to validate the results. The basics of error evaluation is to use an independent source to check the validity of the classification for each of the classes chosen for the study. The basic rules for the classification are-

1. The accuracy evaluation should be carried out with testing data that is not the same as those used to train the classifier.

2. There should be many test pixels - ideally several hundred.

3. The test pixels should be randomly placed.

4. Each class should have a minimum number of test pixels.

5. The ground reference data should be obtained independently from the data used for classification.

Typically, in remote sensing, two different types of accuracy are used: user's accuracy and producer's accuracy.

\section{2-1 User's Accuracy}

The user's accuracy is used to assess the reliability of the maps produced in the study. It predicts the chances of what is shown in the map can be accurately found in the real condition. The user's accuracy is used to establish the level of trust one can have to a class designated on the map.

Errors of commission (if expressed as a percentage) $=100 \%$ - User's Accuracy

\section{2-2 Producer's Accuracy}

The producer's accuracy is used to assess what proportion of class has been identified correctly in the classification. It describes the chances of a pixel in image belonging to a class is labeled in that class or not. The user's accuracy is used to establish the level of trust that areas on the map that are NOT labeled a certain class, are indeed not that class.

Errors of omission (if expressed as a percentage) $=100 \%$ - Producer's accuracy

\section{2-3 Kappa Statistics}

The kappa statistics are used to explain whether the results obtained in the study are the outcome of a random chance or not. Kappa penalizes for guessing and always reduces the overall accuracy. All the reviewed studies conducted accuracy assessments. In most of the cases the MSS images produced were least accurate due to the core's spatial resolution (Dewan \& Yamaguchi 2009). The mapping accuracy ranged between $85-90 \%$ with kappa statistics around 0.80 (Ahmed et al. 2013). 


\subsection{Scope and Limitations of using Remote Sensing}

The combination of using RS with GIS can play a vital role in development of future planning strategies. Using RS is comparatively cost-effective method instead of using ground based traditional survey methods (Ahmed et al. 2013). For research carried out in developing nations like Bangladesh, RS techniques are particularly useful. With RS, it is relatively easy to collect data and analyze them for a vast area within a short period of time (Dewan \& Yamaguchi 2009). This may result in taking decisions faster to come up with the changing environment.

On the other hand, RS has its problems too. The main problem related with using RS is availability of data and the difference in type of data. In many places of the world, high resolution images might not be available. In most of the studies, data from many different source and scale were used which can create lots of problems in the analysis phase.

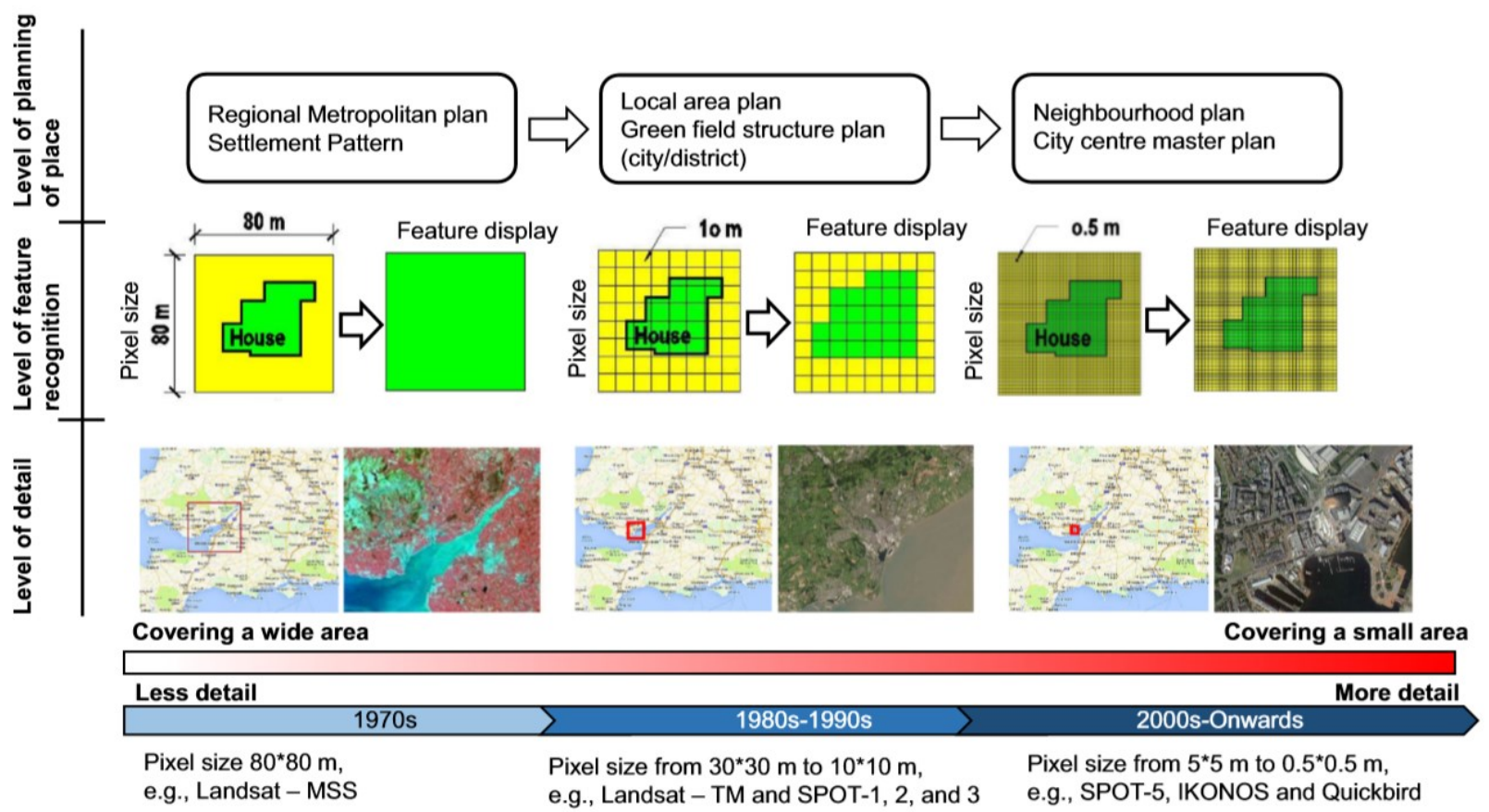

Figure 3.1: Comparison of satellite generations in terms of detail (Kadhim et al., 2016)

For the classification, due to the heterogenous nature of the urban surface, mixed pixels were a common problem while working with Landsat Data. Wetland class easily gets merged with low land class due to the similar reflectance properties. Wetland and low land categories also got mixed up with cultivated lads (Dewan \& Yamaguchi 2009). But despite these problems, the accuracy of the maps was satisfactory in all the studies reviewed and accuracy of RS classification can be further improved by using rule-based techniques and combining with GIS tools. 


\subsection{Urban Density/Urban Development}

The world's population is continuing to grow and so as the urban population. Before this century, city planners and social reformer thought it is good to reduce density to improve the overcrowded industrial city but later, since the 1970s it is proved that higher densities bring positive impacts on various social and economic sustainability, include efficient public service and infrastructure making a lower environmental impact and make a more vibrant urban community. The modern trend of urban planning emphasizes mixedused planning rather than urban sprawl. Urban sprawl is that kind of development that creates a network among multiple localities at different scales and creates separate zoning. This kind of development increases the automobile-based living community which effects on increasing of overweight and energy consumption (Figure 3.2).

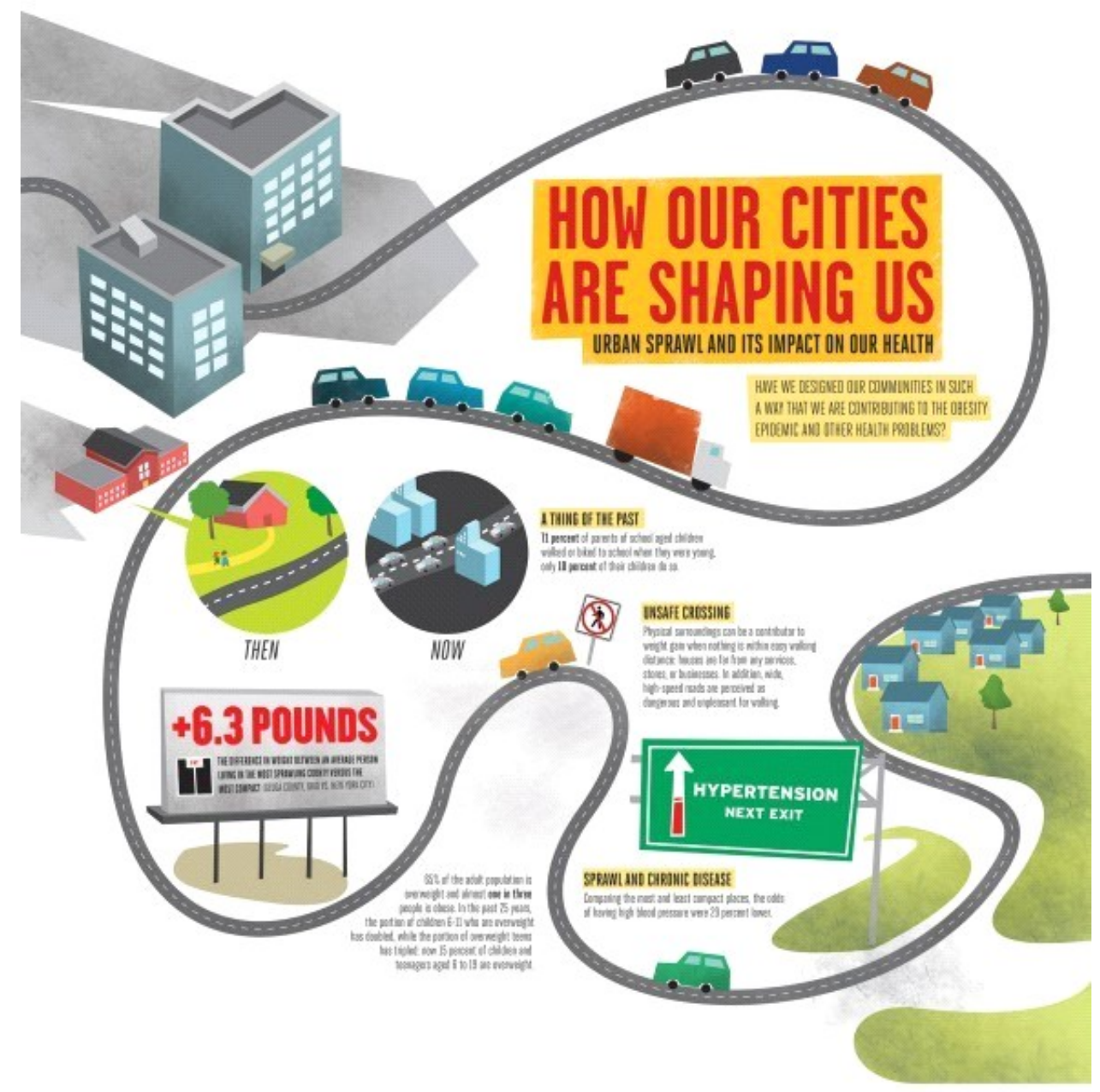

Figure 3.2: Adverse effects of automobile-based living community (Source: https://visual.ly/community/Infographics) 
No less than 63 percent of the American population is overweight today and which is fueled by the development of an ongoing automobile-based community (Mostafavi 2016). The number of overweight children age 6-11 is increased doubled in the past 25 years and it is tripled in the case of overweight teens. So, to give importance to densify and design more compact cities, making closure collaboration between public and private sectors is now time demands.

The benefits of higher-density development according to research are:

\section{Reduced automobile dependence:}

Higher density works against urban sprawl where dwelling unit density increases for a region, so distance traveled by car is decreased and includes the provision in favor of walking, cycling, and public transit (Miller \& Shalaby, 2000; Cervero, 1998: ch. 3; Newman \& Kenworthy, 1999: ch. 3).

2. Increased safety, social cohesion, commercial dynamism, and pedestrian access to amenities:

Higher density ensures different types of public gathering in one place which can promote safer and economically dynamic urban environments (Jacobs, 1961). Different types of community facilities like parks, libraries, schools, street shopping areas are evolved to fulfill the demand of urban crowed (Churchman, 1999).

\section{Less consumption of rural land and greater environmental sustainability:}

Higher density of new development ensures to lower the consumption of rural land converted to urban use and greater the opportunity to preserve agriculture land, wetlands, and environmental areas. Patterns of higher-density development can make less impact on the natural environment (Berke et al., 2003; Gordon \& Tamminga, 2002).

\section{More efficient infrastructure use at a lower cost:}

High density can reduce the cost of infrastructure per capita. As high urban density reduces the travel distance so, it shortens the distance for the pipe and wires of distribution system like water, sewer, electricity generation plants, and other utility services. (IBI Group, 1990). 


\subsection{Sustainable Corridor}

Corridor especially urban corridors are the main type of land use for transportation concepts. The road network which emphasizes efficiency, safety, comfortability, easy accessibility, economic friendly is called Sustainable corridors. They allow people to pass from their immediate proximity to another without relying on cars or other wasteful and inefficient products. Sustainable corridor introduces pedestrian mode, bike lane, public transportation, and transit-oriented development. The image shows the necessity of increasing public transport mode to develop a sustainable corridor.

\section{5 persons...}

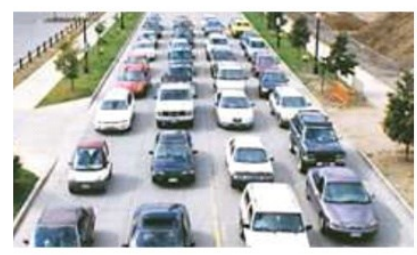

... in individual cars

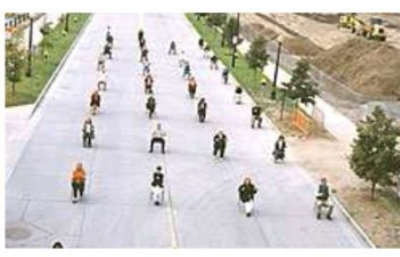

... without their cars
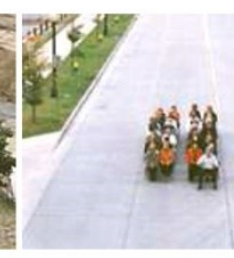

$\ldots$ in a bus

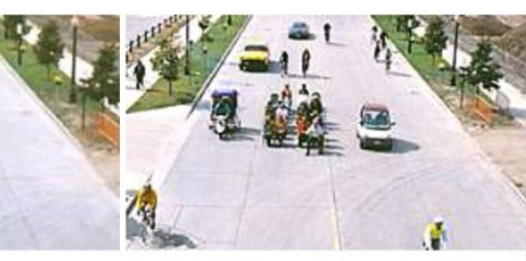

... with other users of the road

Figure 3.3: Comparison between different mode of travel. (Source: http://www.codatu.org)

The sustainable corridor also allows animals to move around which means it includes biodiversity corridors so that animals may still live in and around cities. (Douglas, 2008).

So, in urban planning, the sustainable corridor must have at least three parts: habitat corridor, transportation corridor, and utility corridor.

According to the Institute for Transportation and Development Policy, there are 8 Principles of the Transit-Oriented Development (TOD) standard for designing better streets and better cities:

- WALK: Develop neighborhoods that promote walking

- CYCLE: Prioritize non-motorized transport networks

- CONNECT: Create dense networks of streets and paths

- TRANSIT: Locate development near high-quality public transport

- MIX: Plan for mixed-use

- DENSIFY: Optimize density and transit capacity

- COMPACT: Create regions with short commutes

- SHIFT: Increase mobility by regulating parking and road use 


\subsection{Sustainable Neighborhood}

The theory of sustainable urban neighborhoods emerged in the UK in the 1990s. Neighborhoods are where changes take place, development decisions are made, and where residents experience the city environments. Sustainable neighborhoods are the blocks of sustainable cities. Sustainability starts in the neighborhood.

There are various approaches to sustainability in the neighborhood. Among those, two are very different but very integrated with each other. One is the social perspective, and another is the ecological perspective. There are 7 components from the social perspective for the sustainable neighborhood:

- governance;

- transport and connectivity;

- services;

- environment;

- economy;

- housing and the built environment;

- sociology and culture

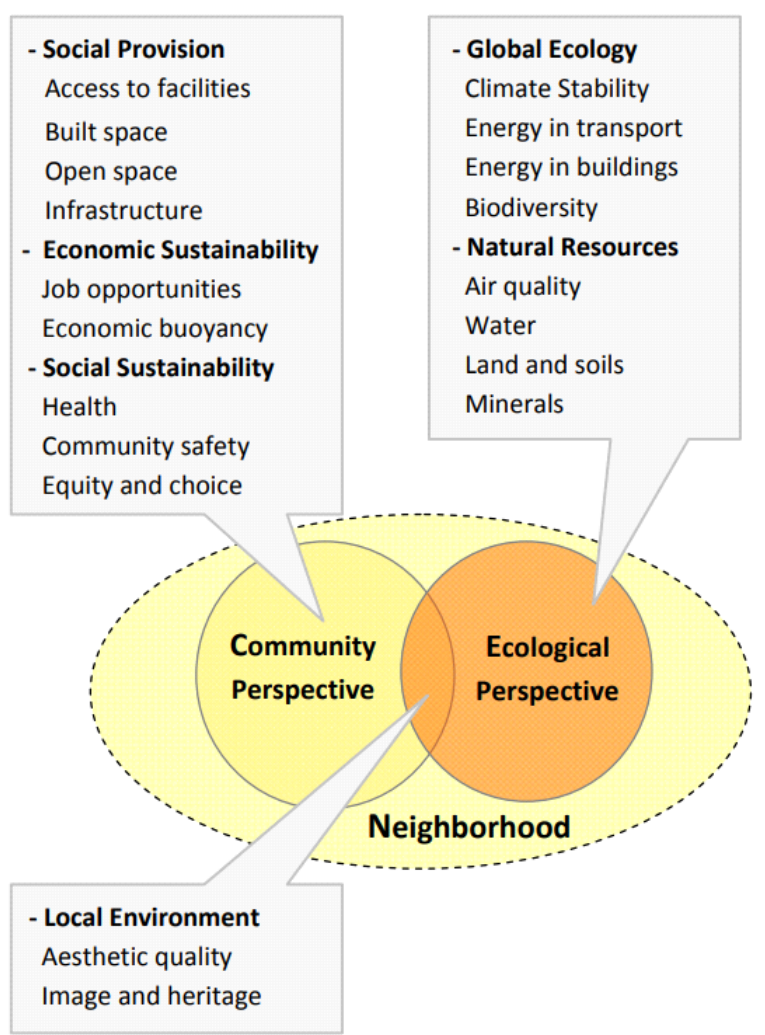

Figure 3.4: Sustainability dimensions applied to neighborhoods. (Source: Al-Hagla, 2008) 
From ecological point of perspective, the neighborhood seems to an ecosystem which provides comfort and sustenance to its humans and creates microclimate conditions which improve air and water condition, reduce land and soil erosion and increase natural minerals in soil as well as local aesthetic quality.

There are four pillars of urban sustainability.

1. Energy: A sustainable neighborhood will focus on and shares ownership of renewable energy technologies. The dwellers should live in passive energy-saving multi-dwelling buildings. There should be an innovative solution to manage resources and stimulate recycling.

2. Socio-economic balance: In a sustainable neighborhood, there should be local and organic food cooperatives that should run by neighborhood residents. This creates a strong social and ecological balance that influences the local trade system and provides a strong impact on the local economy.

3. Sustainable transport: A sustainable neighborhood will have an efficient public transport system with the provision of cycling and walking. Travel distance should be minimized with a compact building layout.

4. Urban design elements: Multipurpose community space, central plazas, green spaces, public spaces, pedestrian street, bike trails, etc. are the elements of urban design and planning which can promote social activities, people can meet here to promote not only their health practice but also to be social.

An example of a sustainable neighborhood is the Western harbor in Malmö, Scandinavia. This formerly contaminated industrial land has been redesigned as a new neighborhood with good public transport links and pedestrian and cycleways to discourage dependence on a car. Buildings are mix-used located around a square, where people can gather. There are systems for managing waste and water sustainably. 


\subsection{Biophilia}

The term biophilia was used by German-born American psychoanalyst Erich Fromm in The Heart of Man (1964), which described biophilia as "the passionate love of life and of all that is alive." Later American biologist Edward O. Wilson used this term in his work Biophilia (1984), which proposed that the tendency of humans to focus on and to affiliate with nature and other life-forms has, in part, a genetic basis."

Evidence suggests that humans are attracted to nature. Humans like the appearance of nature. They use nature in their language such as "blind as a bat", they search for a spiritual experience in nature or from nature and search for emotional connections with nature and animals.

The design discipline which connects human with nature calls biophilic design. It reduces stress and improves well-being, cognitive function, and creativity. It is the innate biological connection with nature for humankind. Good biophilic design respect the mind-body system of the health of human and the well-being for context which is appropriate for the locality. Biophilic design can be organized into three categories in terms of incorporation into the built environment:

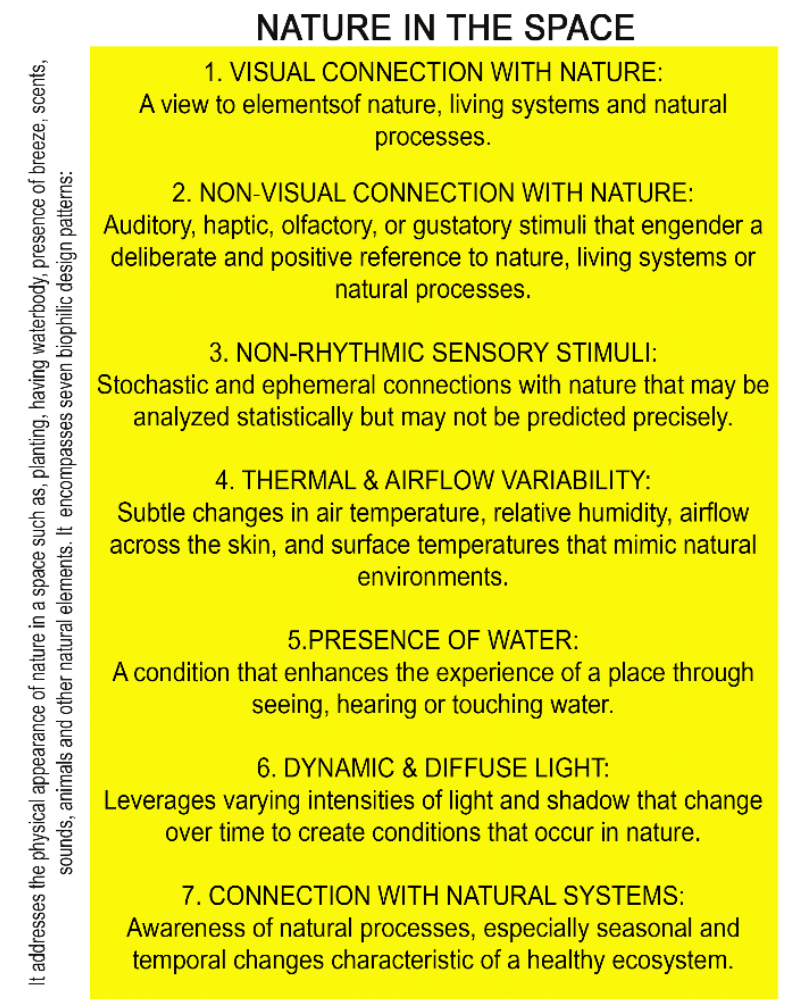

Figure 3.5: 14 Patterns of Biophilic Design

\section{NATURAL ANALOGUES}

1. BIOMORPHIC FORMS \& PATTERNS:

Symbolic references to contoured, patterned, textured or numerical arrangements that persist in nature.

2. MATERIAL CONNECTION WITH NATURE:

Materials and elements from nature that, through minimal

processing, reflect the local ecology or geology and create a distinct sense of place.

3. COMPLEXITY \& ORDER:

Rich sensory information that adheres to a spatial hierarchy similar to those encountered in nature.

\section{PROSPECT:}

An unimpeded view over a distance, for surveillance and planning.

2. REFUGE:

A place for withdrawal from environmental conditions or the main flow of activity, in which the individual is protected from behind and overhead.

\section{MYSTER:}

The promise of more information, achieved through partially obscured views or other sensory devices that entice the individual to travel deeper into the environment.

4. RISK/PERIL:

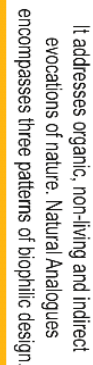

An identifiable threat coupled with a reliable safeguard.

\section{NATURE OF THE SPACE}


Kellert et al. (2008, p7 -15) have divided biophilic design into six design elements. These elements can guide designers and researchers to bring nature closer to people.

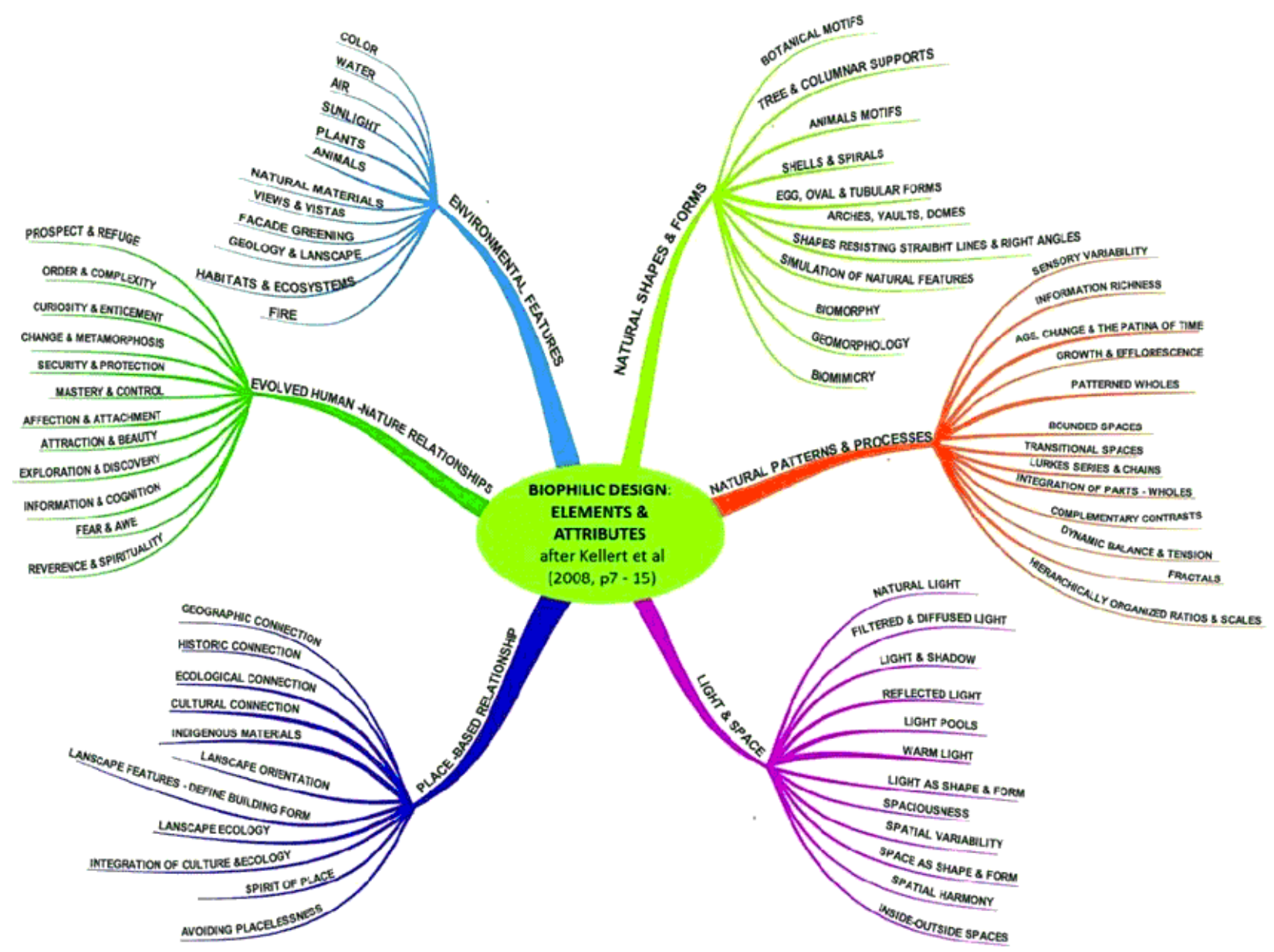

Figure 3.6: Graphic interpretation and summary of Biophilic design elements. (Source: Sayuti et al., 2008)

\subsection{Eco-Urbanism}

Urban design is the synchronization of the quantitative and qualitative process of working. it is the stage of understanding of the dialectic of space, culture, and time. Space is defined by its behavior, need, and function. Space works as a living system, which should follow an ecological design process. Here comes the Eco urbanism. Culture is an umbrella term that is a summation of community behavior and understanding. The culture of Bangladesh was always full of activities of the ecological process. Time provides history, knowledge, past and presents emerging patterns (Ron Kasprisin, 2019). 
The basis of the ecological process is to see nature as a resource for satisfying human needs (Mostafavi et al. 2016). This attitude is not new, rather it is as old as Vitruvius recommendations on-site location, orientation, and natural lighting.

The ecological process leads to sustainable development. "Sustainable development is a development that meets the needs of the present generation without compromising the ability of future generations to meet their own needs" (Mostafavi et al. 2016).

Sustainable development is the basis of Eco urbanism. It generates multidimensional sustainable human communities that should be harmonious and balanced with the environment. It is now the base concept of urban planning of the 21 st century (Mostafavi et al. 2016).

Eco urbanism is a new discipline. It evolves multiple and miscellaneous variables to approach for a systematic urban design which is different from conventional planning. In this discipline, the development which sustains the ecology must be accelerated. Eco urbanism brings a balance between humans and nature.
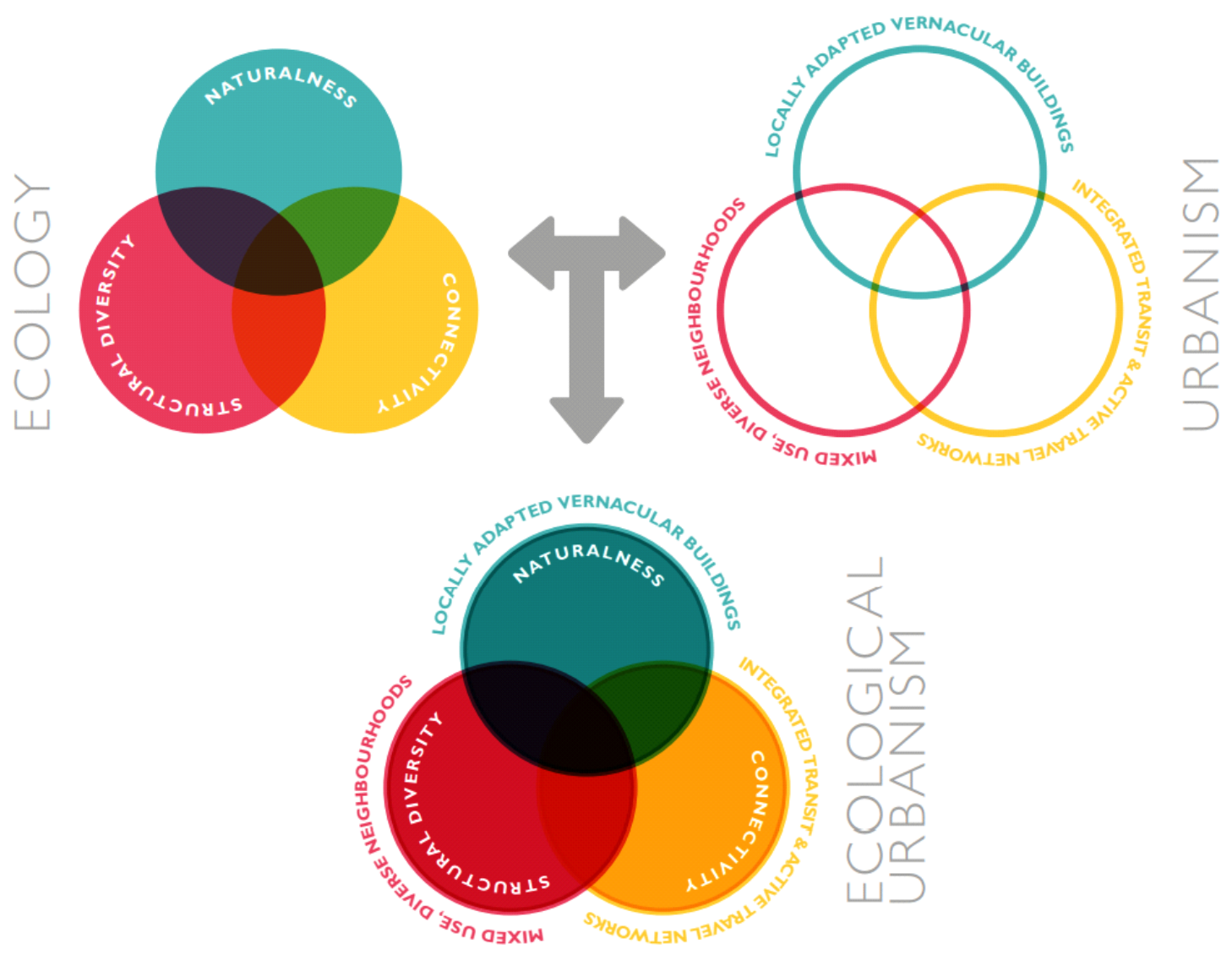

Figure 3.7: A Simple Model for Ecological Urbanism.

(Source: Living Cities: towards ecological urbanism, Policy Futures Series No. 4/2018) 
Ecological urbanism is not limited to a set of rules, it is a broad philosophy. The concepts of Ecological urbanism combine many fundamental ecological principles with fundamental urbanism principles. For example, architect and urban designer Peter Calthorpe pioneered a new urban design movement which promotes environmentally friendly habits (Calthorpe, 2010). This concept is known as New urbanism. New urbanism focuses on human-scaled urban design and is defined by 10 principles:

\section{Walkability}

2. Connectivity

3. Mixed-use and diversity

4. Mixed housing

5. Quality architecture and urban design

6. Traditional neighborhood structure

7. Increased density

8. Green transportation

9. Sustainability

10. Quality of Life

These principles are closely related with 'sustainable urbanism' principles. In Felix Guattari's 'The Three ecologies', he listed three registers for his concept of 'ecosophy' (Félix et al., 2000):

\section{Environmental Ecology - Environment}

2. Social Ecology - Social Relations

\section{Mental Ecology - Human Subjectivity}

Mohsen proposed eight directions of ecological urbanism:

\section{Sensibilities and Practices to urban development}

2. Multi-Scalar Design Strategy

3. Sustainability \& Connectivity

4. Imagination

5. Locality

6. Flexibility

7. Political \& Politics

8. Disagreement

Extending from Guattari's points, Mohsen wanted to establish a cross-disciplinary and collaborative approach to further integrating the concept of Ecological urbanism with urban development. All these principles and concepts can be brought together under Eco-Urbanism to develop an urban realm existing in harmony with natural elements. 


\subsection{Urban Metabolism}

Cities around the world are going through an exponential rate of energy use trends. Currently, more than half of the population around the world lives in urban areas and the number is increasing every day. Cities need natural resources to develop and sustain this huge population. The natural resources any city uses can be calculated through its net carbon footprint. Most of the cities around the world have many times larger carbon footprint as cities are harvesting the resources at a tremendous speed. This creates a linear flow of natural resources as modern society has developed a tendency to produce, consume, and discard. To preserve our scares natural resources and create a sustainable future, the cities need to move from a linear resource flow system to a circular one.

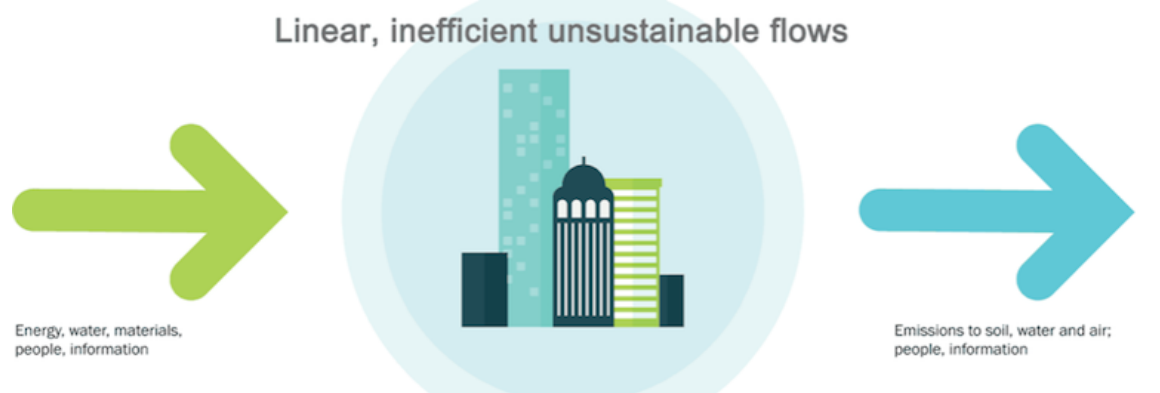

Circular, more sustainable flows

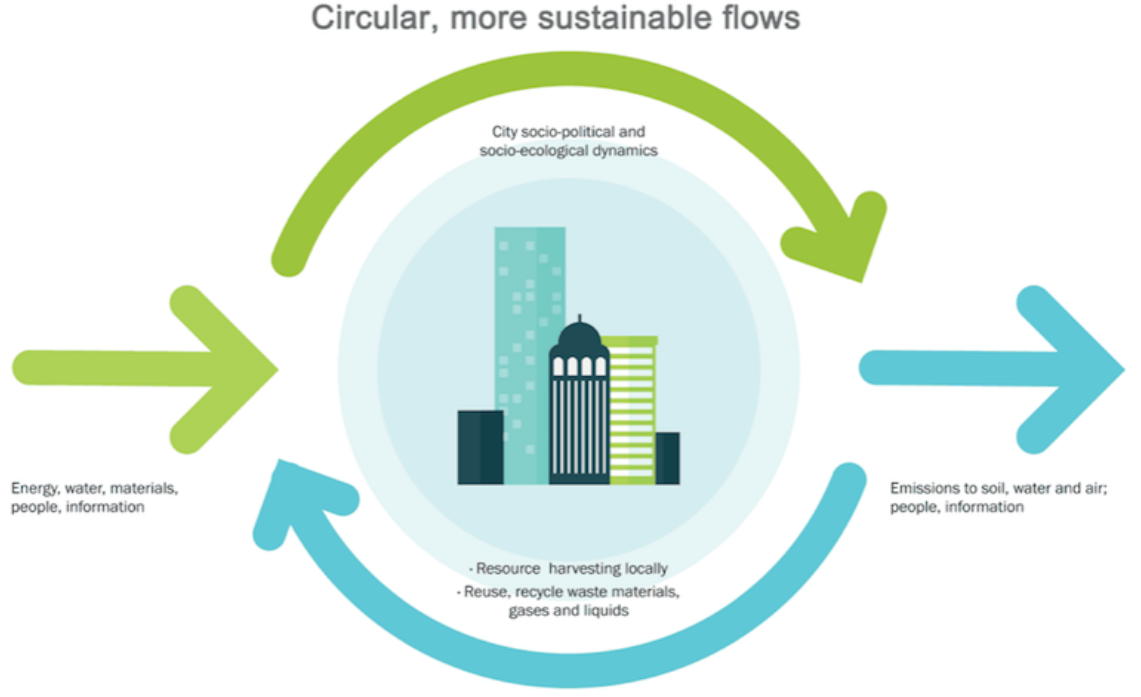

Figure 3.8: Shifting City Resource flow. (Source: http://www.iaacblog.com)

Cities can be compared with living organisms. Like any living cell, cities need external resources for their survival, cities transform these resources to produce consumable products and simultaneously produce waste materials as it consumes them (Duvigneaud, 1977). Like living organisms, cities adapt to their surroundings and grow when the conditions are favorable. By promoting the practice of Recycle, Reduce, and Reuse in every step of city metabolism, we can create a circular recourse flow within the city. The cities of the future must incorporate these circular strategies within the design. 


\subsection{Historical Growth Pattern Analysis}

Cities around the world has its unique growth characteristics. The history and growth of a city can be traced back by analyzing its urban fabric. Many cities may have evolved slowly with little overt direction, a product of the interaction of the defense perimeter, the subdivision and development of individual properties, and the needs of collective institutions.

By contrast, preconceived designs were likely to be imposed when cities were rebuilt after a war or when new cities were founded as colonies or military outposts.
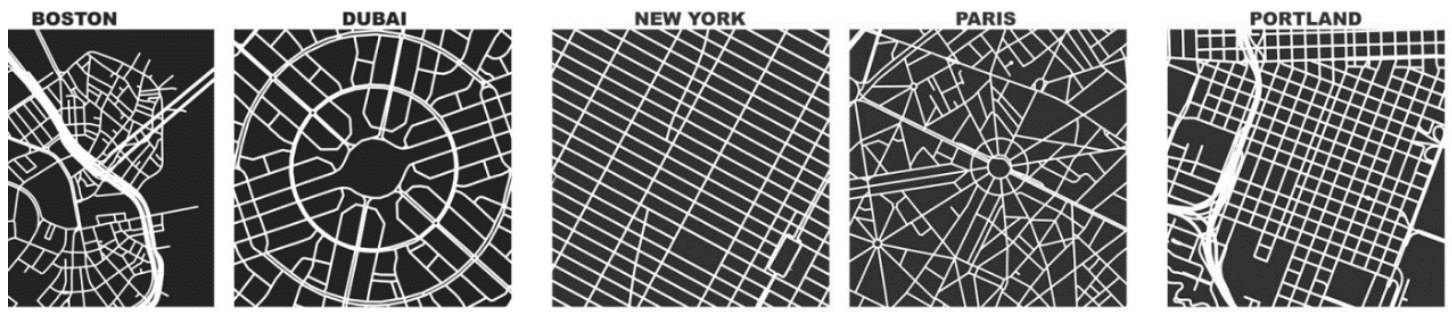

SAN FRANCISC
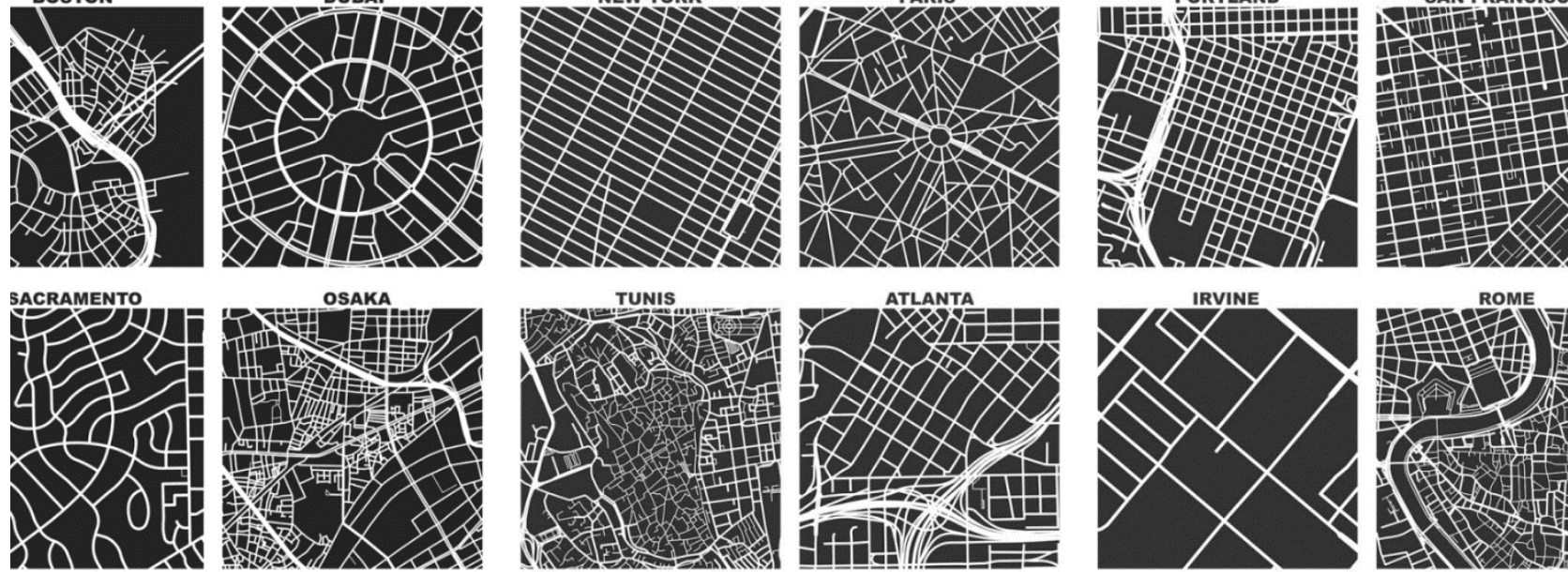

Figure 3.9: Historical growth pattern analysis (Source: Boeing 2017)

\section{Pre-Industrial City Design System}

The cities in the pre-industrial era were mostly self-contained and have a relatively slow growth rate. The location of a city was determined by presence of natural resources like easy access to water, higher elevation from surrounding to protect from flooding. The city boundary was often marked by surrounding fortification walls and city center had royal palaces or structures with religious significance. German architect and city planner, Karl Gruber published a series of drawings in 1914, describing the evolution of a hypothetical German city from the twelfth century to the eighteenth.

The three drawings (1180, 1350 and 1580) in Karl Gruber's sequence illustrates the relatively slow development of cities. Four hundred years have passed, the city has grown on the south bank of the river, the fortifications have been improved and the castle and cathedral are rebuilt but it is still recognizably the same place. 

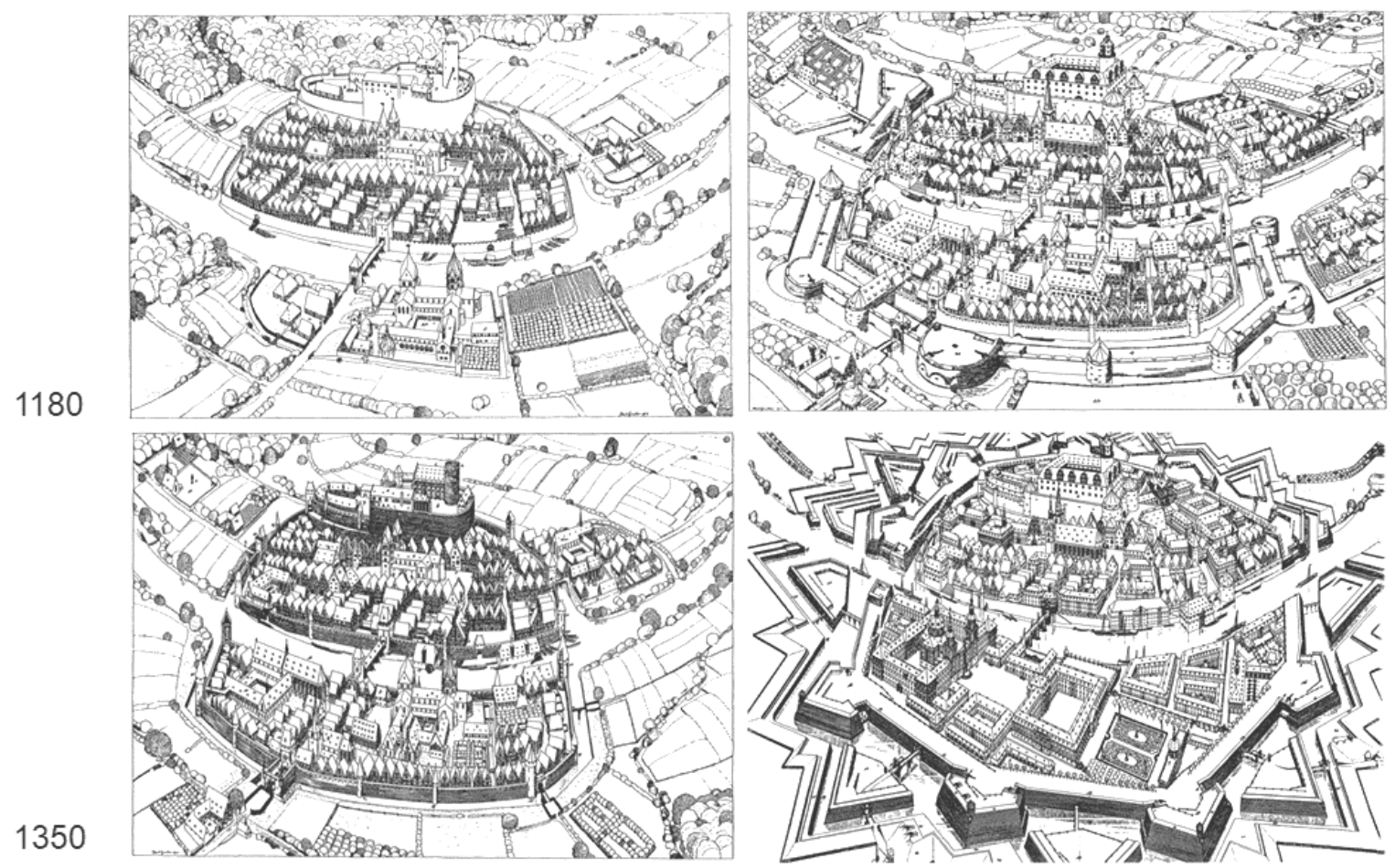

Figure 3.10: Evolution of a Pre-Industrial City by Karl Gruber (Source: Barnett 2016)

The fourth Gruber drawing, showing the same city in 1750, illustrating the effect of the Thirty Years War on urban fortifications and the new Renaissance concepts of city design that have reorganized and transformed the city. However, it is still recognizably a preindustrial city, with the same systems organization that it had some six centuries before.

\section{Urban Systems After the Industrial Revolution}

One of the changes set in motion by the French Revolution was the adoption of a new system of standardized weights and measures, the metric system. The standardization of building components, which had produced the cast-iron and later, steel rails that made train travel possible, also created the building systems which allowed urban development to achieve the new densities enabled by trains.

After the industrial revolution, cities started growing rapidly to house huge number of populations working in mills and factories. The grid pattern provided quick and easy solution to plan these expanding cities as if the modularity of building system transformed into city scale.

In USA, almost all newly established cities embraced a grid layout plan with different hierarchy of space organization. Philadelphia was one of the first cities in North America to use a grid system and later other well-known cities like New York City, Washington, D.C. etc. also developed following grid layout. 

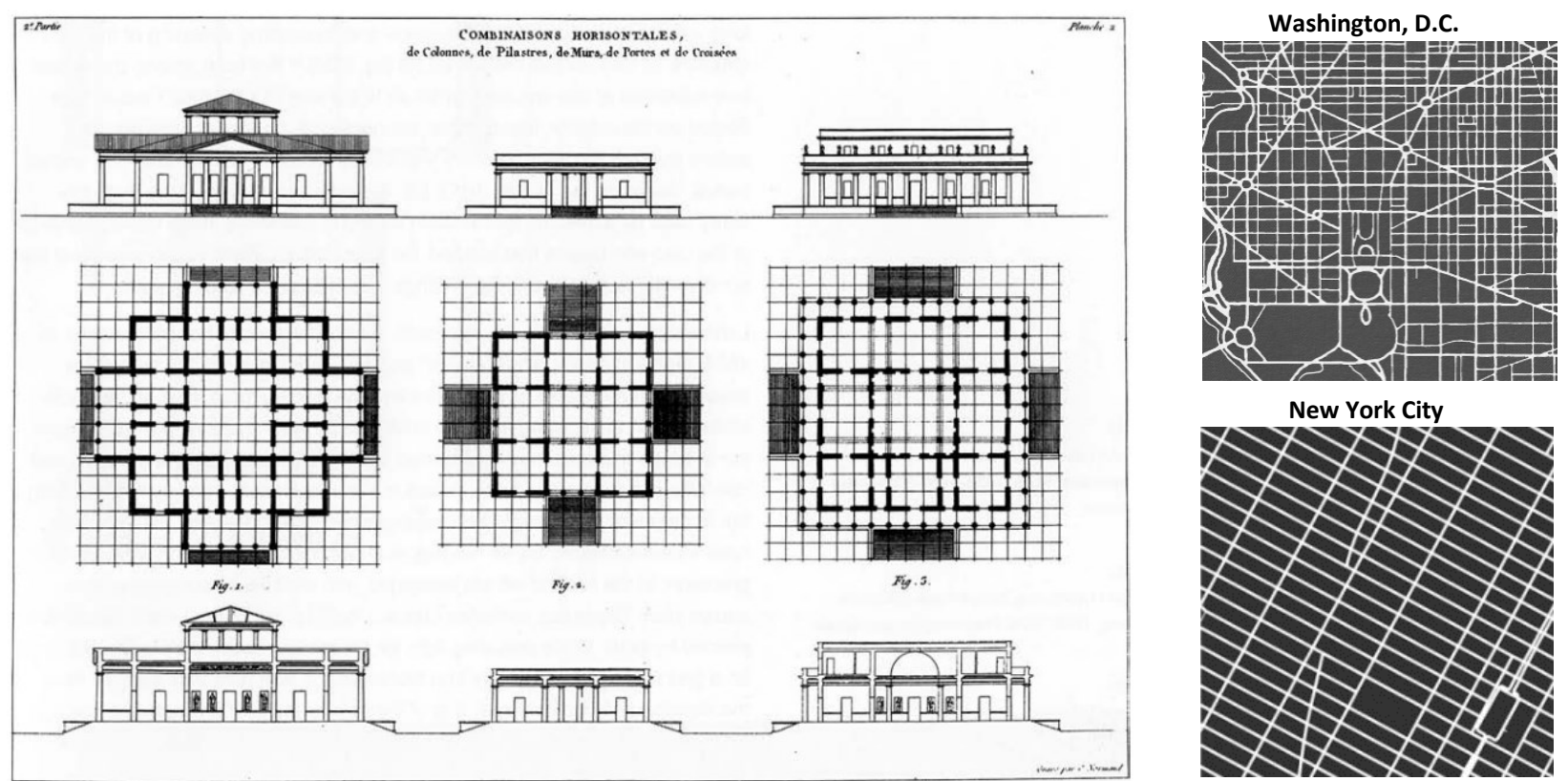

Figure 3.1 1: Modularity from Individual Building to Urban Scale (Source: Picon 2000, An illustration by J-.N-.L)

6

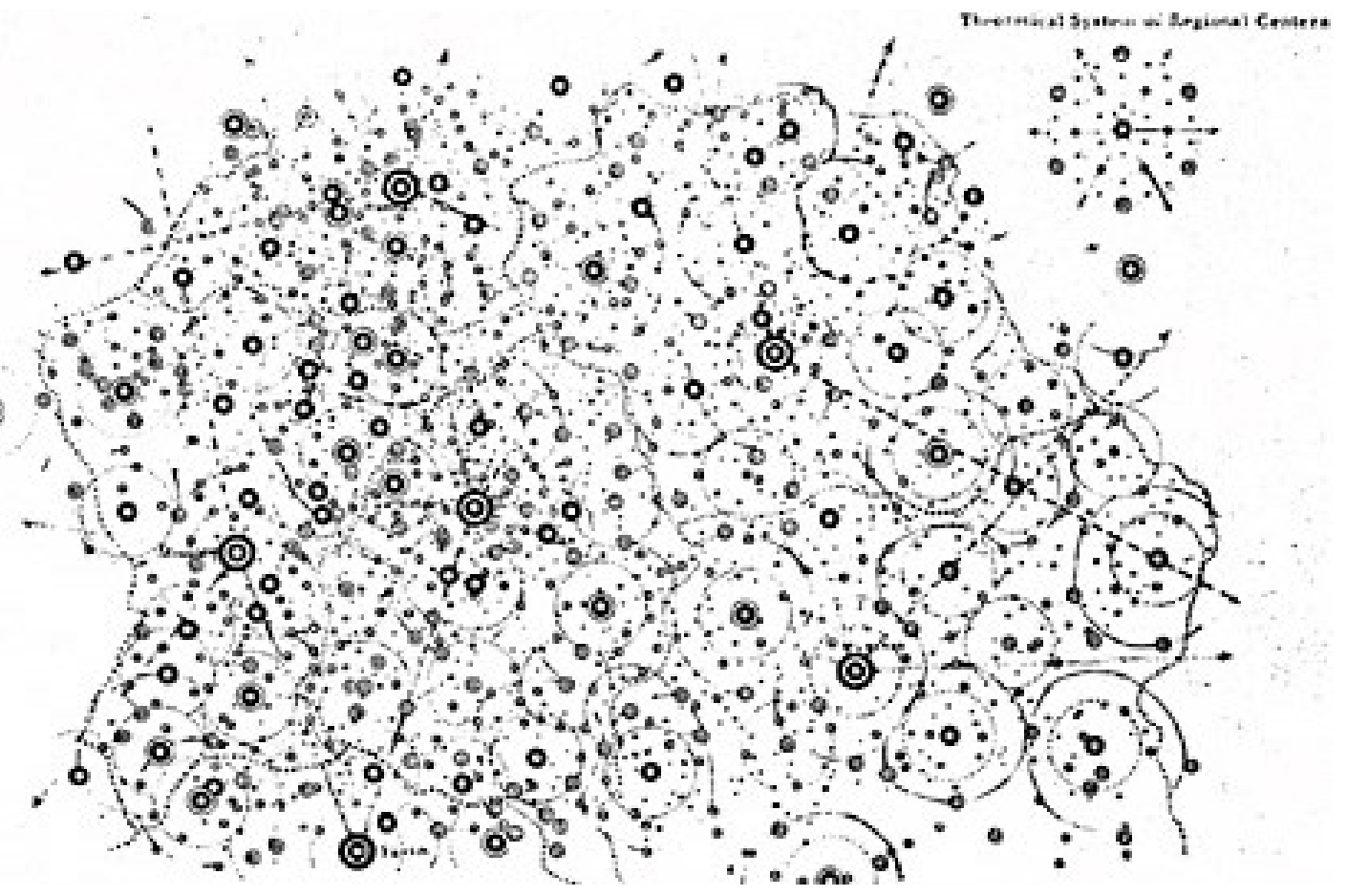

Figure 3.12: Diagram of Central Place Theory by Walter Christaller (Source: Barnett 2016)

With the development of transportation network, cities which were previously isolated got connected with each other. This created a hierarchy of different types of city from regional centers to large metropolitan. Diagram of Walter Christaller's Central Place Theory shows the hierarchical grouping of urban areas determined by railroad systems. 


\section{Utopian cities}

What should be the Utopian visions of a total environment in which man would live in peace with his fellow man and in harmony with nature? Between 1890 and 1930 three designers/planners, Ebenezer Howard, Frank Lloyd Wright, and Le Corbusier, tried to answer that question.

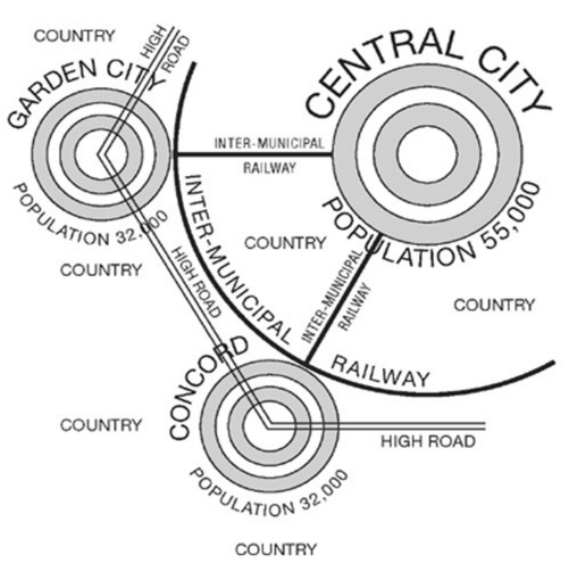

A

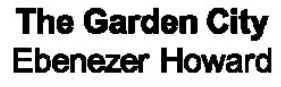

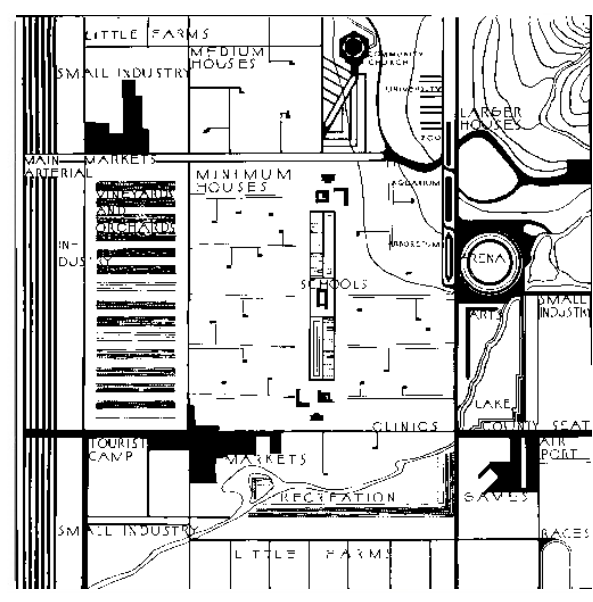

Broadacre City Frank Lloyd Wright

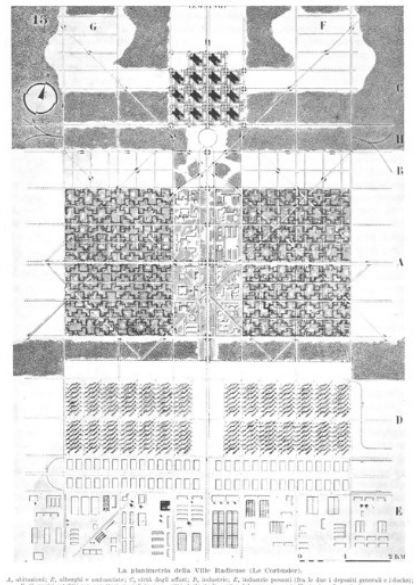

C Radlant Clty

Figure 3.13: Famous Models of Utopian Cities (Source: A. Ebenezer Howard 1898, B. Frank Lloyd Wright 1940, C. Le Corbusier 1924)

\section{Systems City}
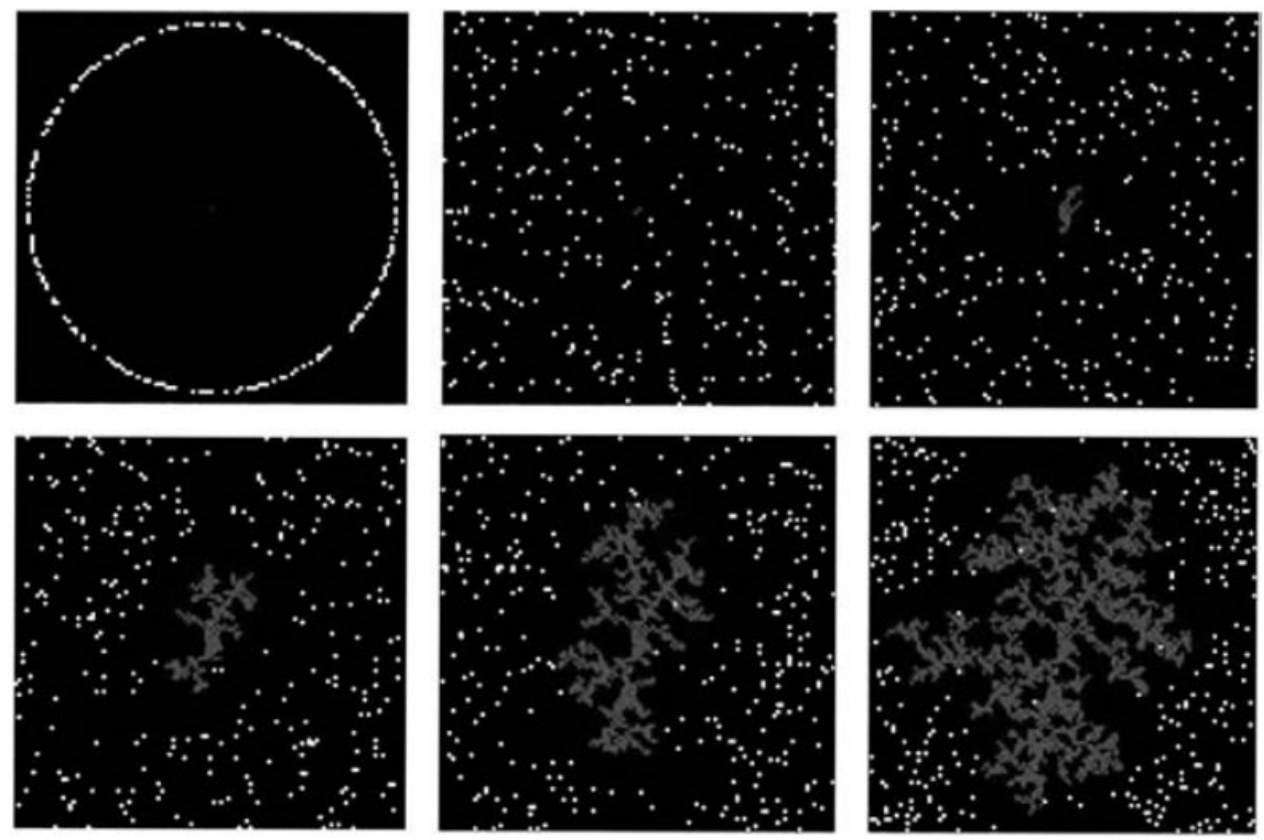

Figure 3.14: Cellular automata to simulate city growth patterns (Source: Batty 2007). 
Experiments by Michael Batty using cellular automata to simulate city growth patterns where the overall development takes its form from a series of local decisions.

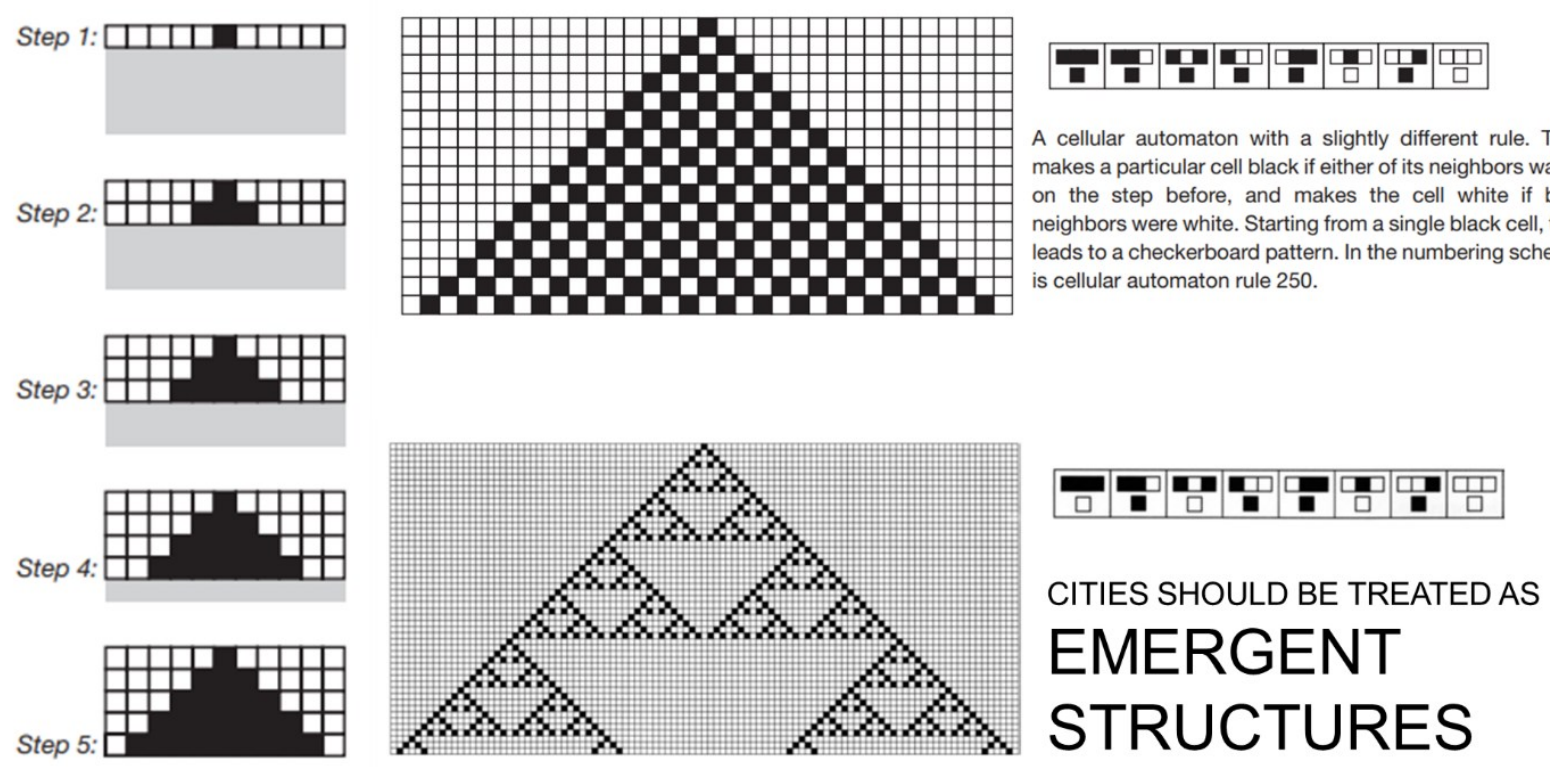

Figure 3.15: Stephen Wolfram's A New Kind of Science (Source: Wolfram 2002)

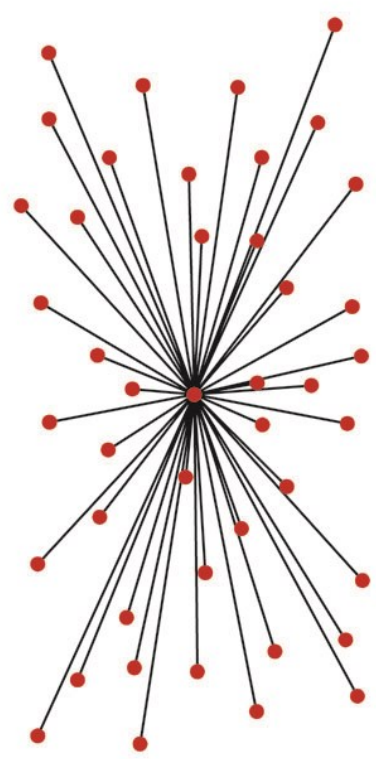

Centralized

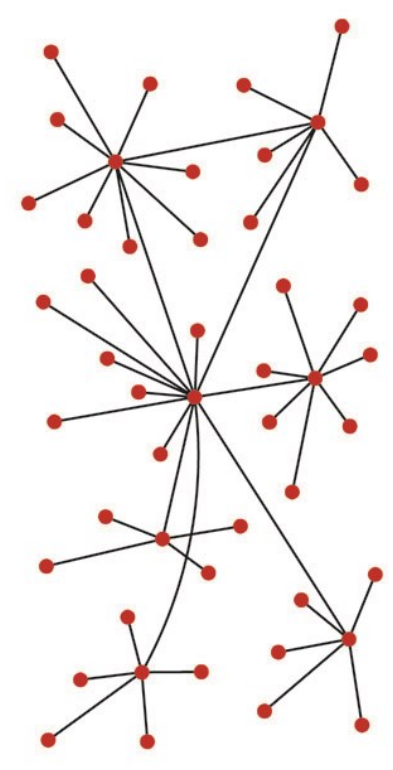

Decentralized

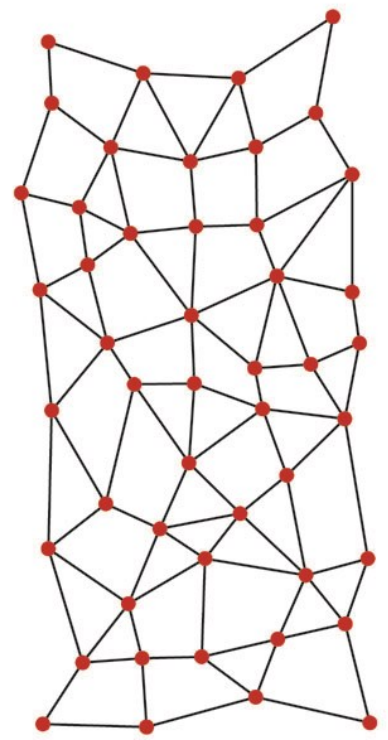

Distributed

Figure 3.16: Patterns of city organization (Source: Baran 1964)

One way to study the emergence of complex behavior from agents acting independently is to create computer programs that set simple rules from which patterns emerge of increasing complexity. 


\subsection{Amsterdam, a Model of City Planning}

Amsterdam is the capital of the Netherlands and is in the province of Noord-Holland. The city elevation is mostly below sea level. Around the year 1000 Amstelland (the area along the river Amstel in the Netherlands) where Amsterdam city stands now was barren countryside. In the 12th century, huge floods swamped much of the countryside. So, in around twelve hundred, the people living in Holland started building dams and dikes.

These formed a protection against the ever-present threat from the waters of the sea. Soon the small town was expanding rapidly. It consisted of many waterways crisscrossed with streets. Originally designed as a defense city, Amsterdam was composed of semicircles that create tiny islands linked by bridges.
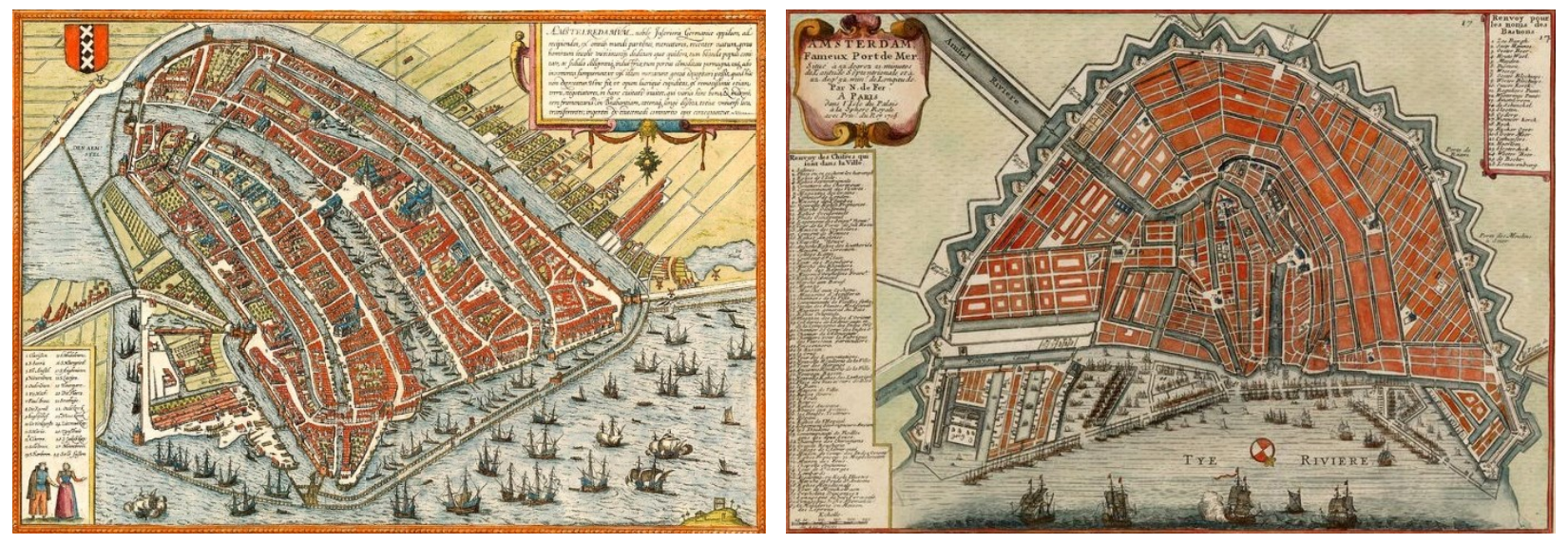

Figure 3.17: Historic development of Amsterdam (Source: http://historic-cities.huji.ac.il)

The city continued to grow during the 19th century. In 1875, Jan Kalf proposed a plan for the city expansion. The plan consisted of a ring of development around the historic cluster. The plan broke the radio centric form by incorporating an orthogonal system based on two directions.

After the devastating North Sea flood of 1953, the new Delta plan would shorten the Dutch coastline by 700 kilometers by closing the primary inlets in four locations. This would drastically reduce the length of levees and dikes that needed to be inspected, maintained and thus decreasing the chances of weak points, jeopardizing the safety of the Dutch people. This huge flood control system eventually added more developable land reclaimed from the sea. The city is still growing and work on its most recent new suburb called lceberg was begun in the 1990s with the actual creation of new land to carry Amsterdam's growth into yet another century. 
Currently experiencing a population boom, Amsterdam is expanding urban development beyond the charming canals. Since July 2008, all tiers of Government in the Netherlands started working on the on the development of the city of Amsterdam to 2040. The plan includes new proposals for the downtown core into communities like North Amsterdam and the Zuidas business district in the south to grow the city smartly.

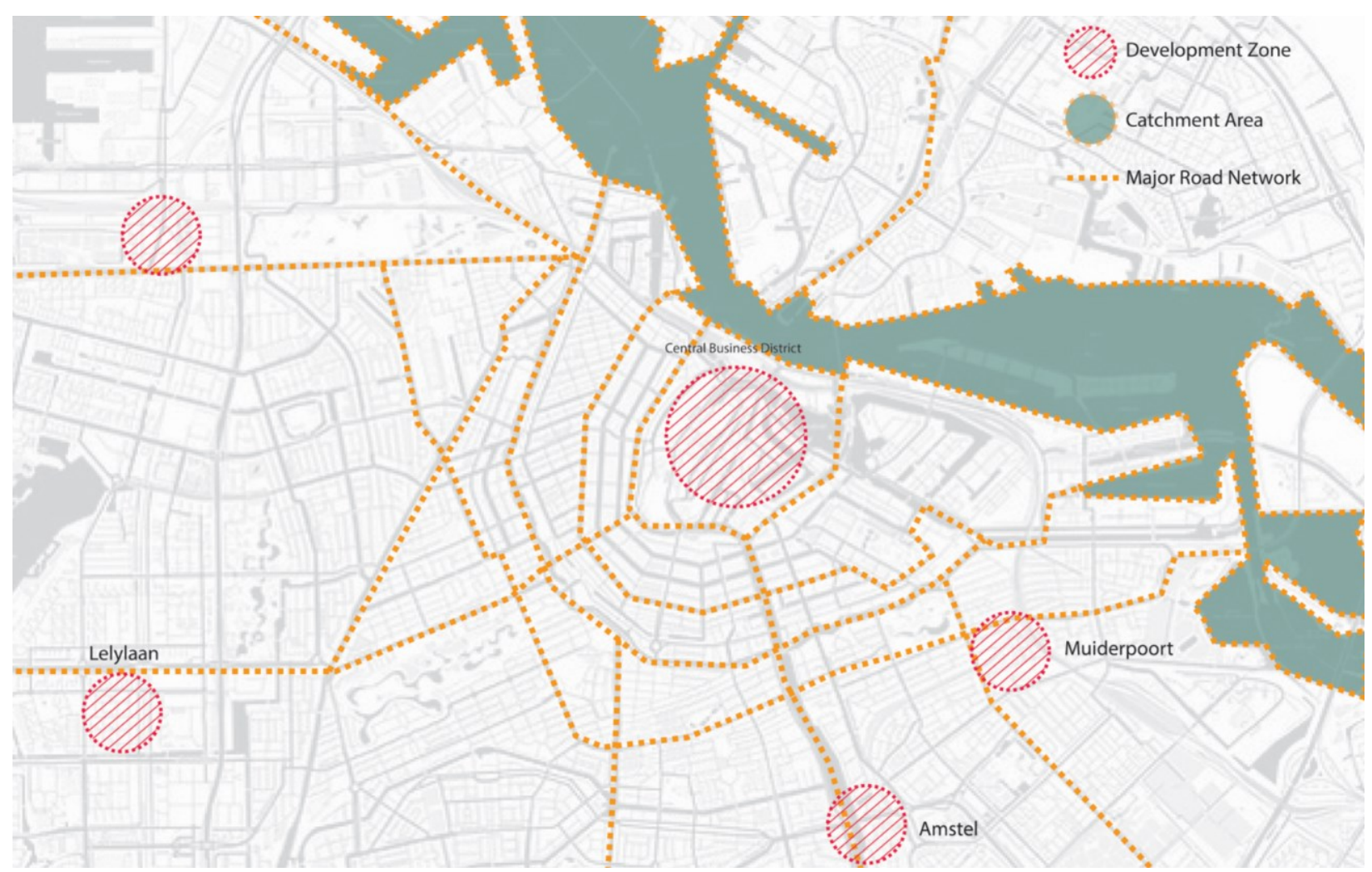

Figure 3.18: Connection of Amsterdam with water (Source: Author)

\section{The structural vision Amsterdam 2040}

The Amsterdam City Council introduced the structural vision Amsterdam 2040 plan on March 2011 . It includes developing office parks into mixed-use residential communities, redeveloping industrial riverfront and building more high rises, windfarms and public transport networks. The plan also incorporates urban design options to host the 2028 Summer Olympics.

Complementing that, Amsterdam smart city initiative is a collaboration of local municipalities businesses residents and academic institutions partnering on over 75 smart city projects. They range from rejuvenating the former industrial neighborhood in North Amsterdam to producing the world's first 3D printed canal house. Four major trends drive the development proposals. 


\section{These four major thrusts are:}

\section{The roll-out of the city center}

2. The interweaving of the metropolitan landscape and the city

\section{The rediscovery of the waterfront}

\section{The internationalization of the city's southern flank}

If Amsterdam can expand its metropolitan footprint while improving its waterways with sustainable design projects, it will become a global beacon for smart urban growth.

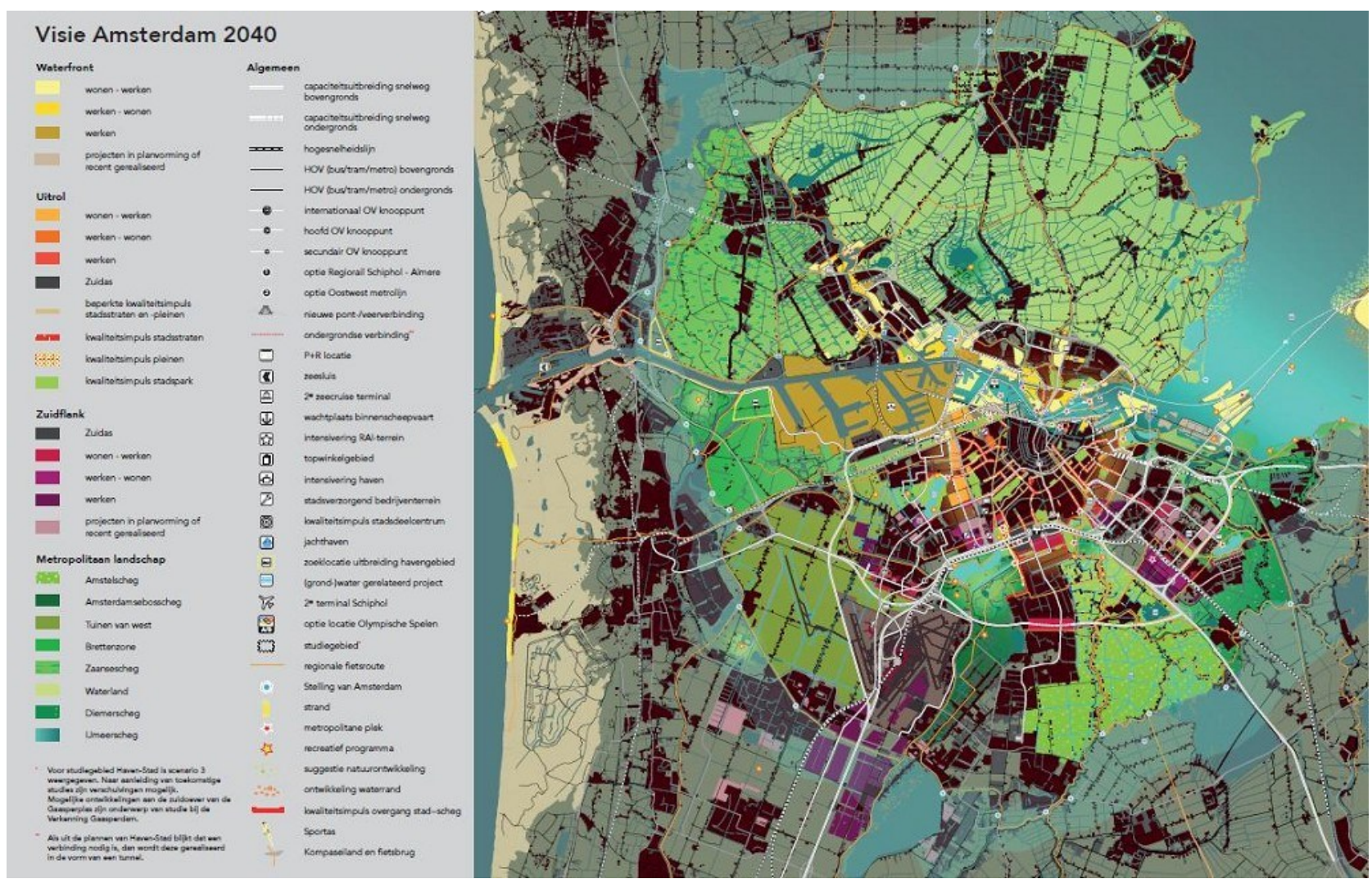

Figure 3.19: Amsterdam 2040 (Source: Economically strong and sustainable Structural Vision: Amsterdam 2040)

Within the vision Amsterdam 2040 plan, the framework contained the following themes and aspects:

Density: To reduce energy consumption and increase transportation efficiency, the Amsterdam 2040 plan proposed new dense urban development strategies. The plan proposed 70,000 new dwelling units to be constructed by the year 2040. To maximize the use of available land, high-rise development and below ground infrastructures were prioritized. These new residential developments will be located near public transportation hubs to promote the use of public transportation. 
Transform: In the new plan, the conversion of single-use business parks into a mixture of residential and business use was proposed. The mixed-use characteristic of the city can promote business by ensuring a better connection with basic amenities.

Public transport on a regional scale: The Amsterdam 2040 plan aims to aims to incorporate regional train, metro and rapid bus transportation for the city. The plan will connect the missing linkage points within the existing transportation network as well as create new infrastructures to ensure a seamless transfer between car and public transport.

High-quality layout of public space: To ensure a high-quality lifestyle for the city dwellers, the new plan prioritized cyclists and pedestrians by providing less space for motorized traffic within the city. The streets where the majority of amenities are concentrated will act as high streets.

Invest in the recreational use of green space and water: Water has been an intricate part of the life of citizens of Amsterdam. The plan proposes to incorporate greenery intertwined with the vast networks of the waterway and make them accessible for recreational purposes.

Converting to sustainable energy: The plan calls for minimizing the energy uses of Amsterdam to make it more energy efficient. By retrofitting the existing buildings with solar panels, developing a closed heat transfer system and installing wind turbines, Amsterdam plans to invest more in sustainable energy.

Olympic Games: Amsterdam 2028: The Netherlands plan to host the 2028 summer Olympic games. Therefore, the plan provided space for the Olympic stadiums and Olympic village.

The Structural Vision: Amsterdam 2040 is a continuation of previous plans for Amsterdam. Perhaps the most unique characteristic of this plan was how it was developed by following a bottom-up developed strategy. The process ensured the participation of every section of society and engaged the people from a multitude of sectors.

\subsection{The development plan for Greater Copenhagen}

The plan was produced by the Danish Town Planning Institute in 1947. The plan allocated five linear development zones radiating from the historic center of Greater Copenhagen and therefore was named "Egnsplan" (finger plan). This Finger plan offered a broad idea for how urbanization of the Copenhagen metropolitan region should be in the future. The linear urban corridors had in between forested zones which created a harmony of the 
natural and built environment. The residential areas were separated by green wedges. The protected public green area between these corridors allows residents access to get connected with natural elements. This finger program has guided the development of Copenhagen for more than 60 years.

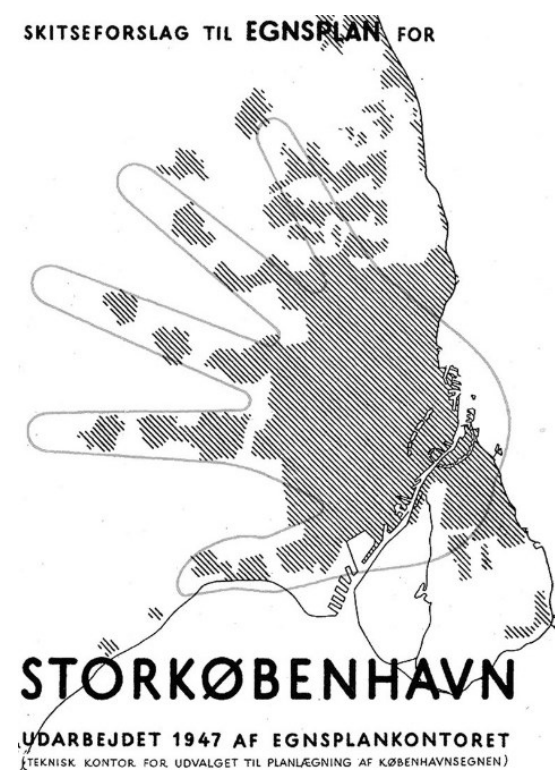

Figure 3.20: Sketch from the first Finger Plan (Source: The Regional Planning Office 1947)

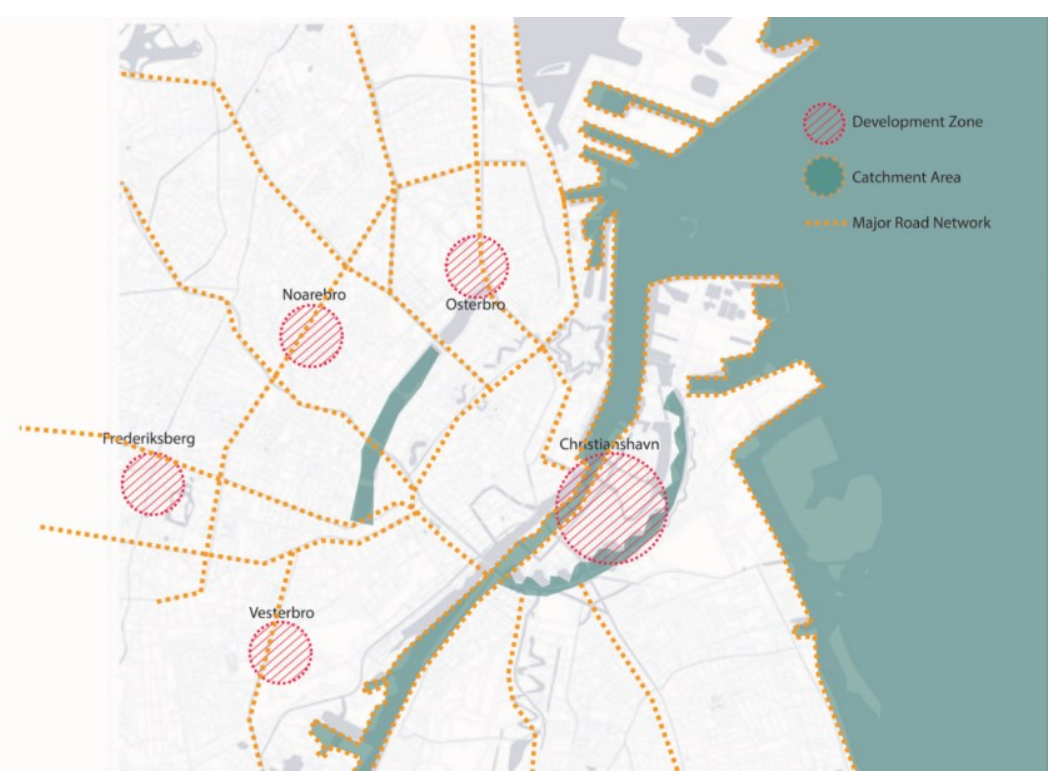

Figure 3.21: Connection of finder plan with water (Source: Author)

These protected green wedges simultaneously prevent further urban growth of the corridors. The development of corridors was connected by transit. The transportation (primarily railway) offers residents easy access to the city area.

The cluster of regional communication axes for trains and automobiles going outwards from the city center along five fingers created the guiding structure for urban development. This finger plan has guided the development of Copenhagen for more than 60 years by turning the city one of the sustainable cities in the world. The main aspects of the plan were:

\section{Urbanization will develop in slender fingers}

Green wedges of undeveloped land will remain between fingers

Finger development will follow public transport (esp. railways)

Suburbs will develop like pearls on a string

Inhabitants will live near green spaces 


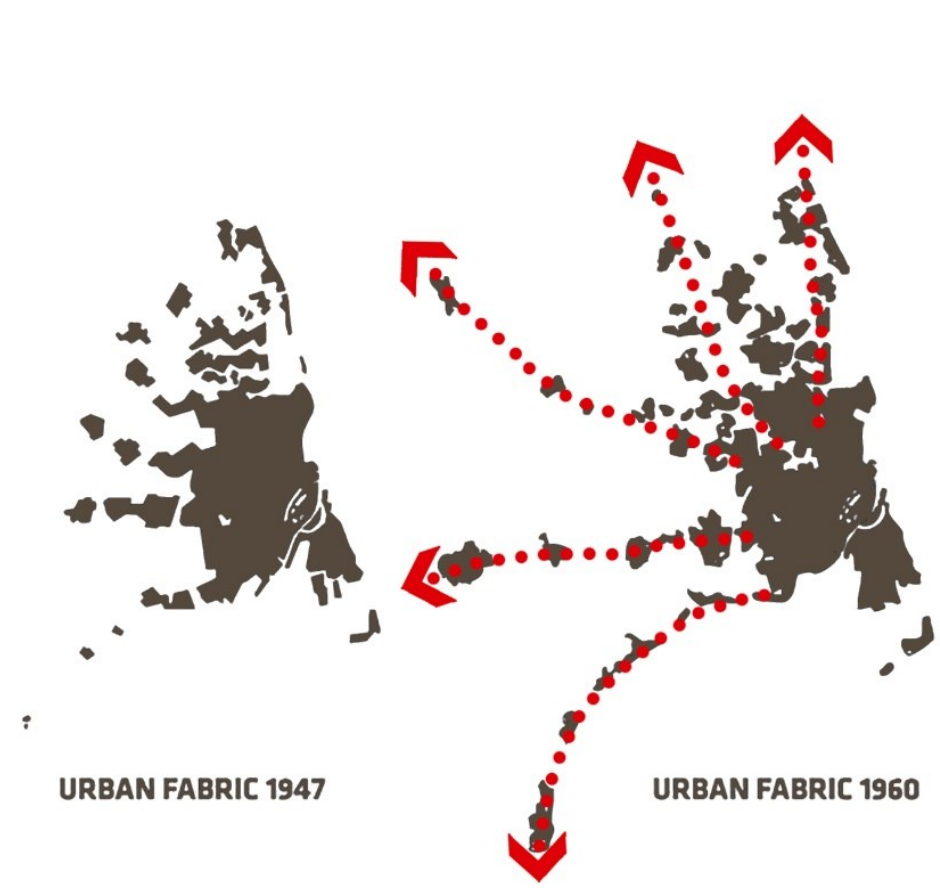

Figure 3.22: Urban growth of Copenhagen http://flash.big.dk/projects/loop)

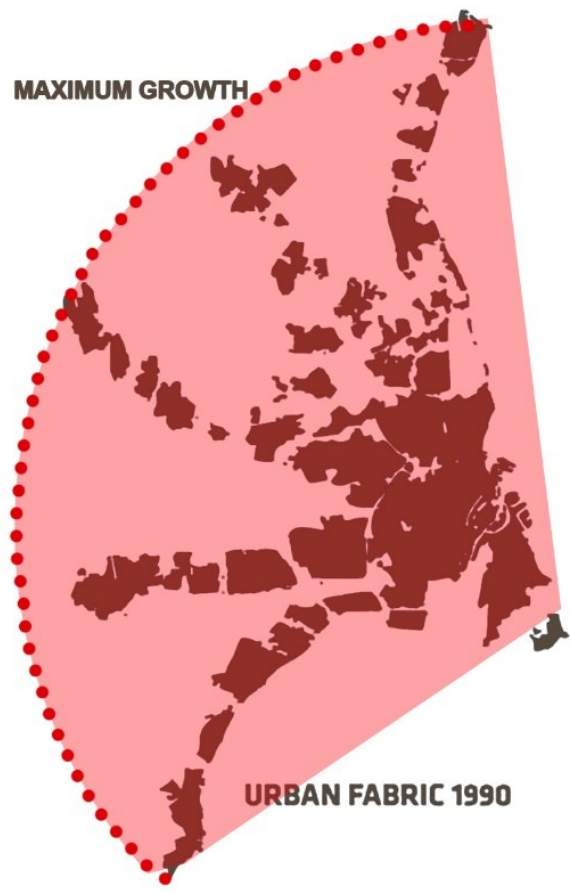

(Source: Adapted from:

In later years, the city saw a higher than the anticipated growth rate. As a result, the Finger plan faced a lot of challenges from recent developments. The plan was periodically updated to provide incorporate current requirements, adjusting the original plan to changing circumstances. The bottom-up grassroots planning strategies integrated with natural elements were the major factors driving the successful formulation and execution of the Finger plan.
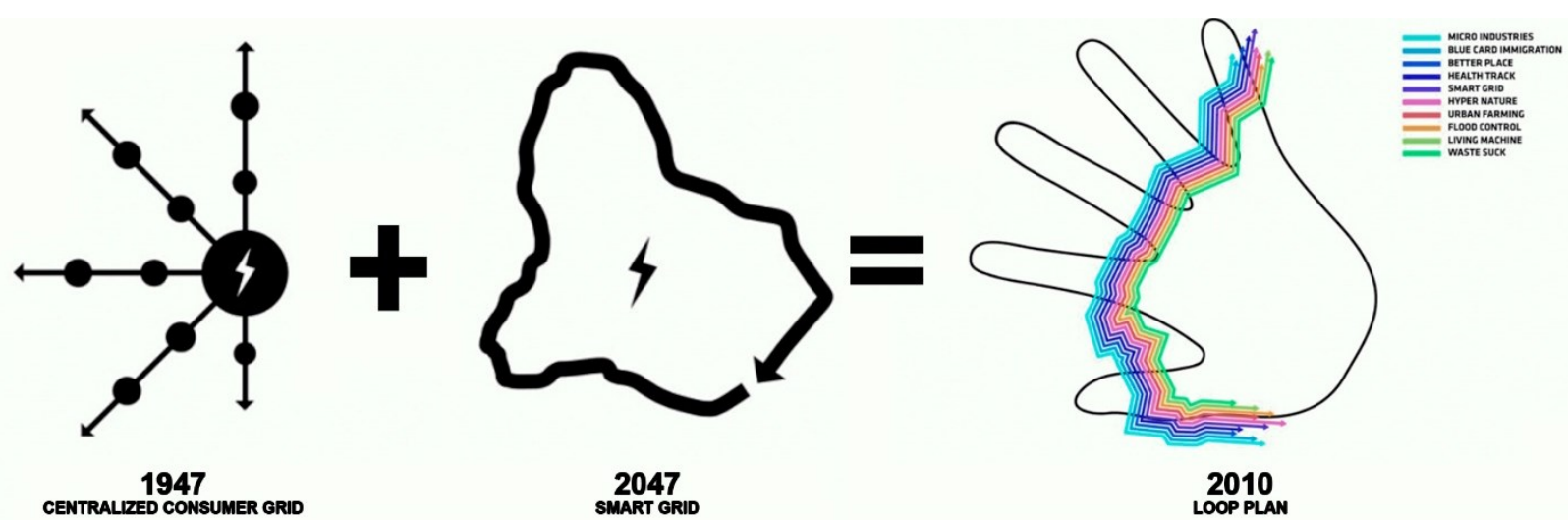

Figure 3.23: Concept of Copenhagen loop plan (Source: Adapted from: http://flash.big.dk/projects/loop)

But during the 1990s, growth in the city had stretched to the maximum limit and it was realized that the finger plan could not sustain itself much longer. The Loop City Masterplan was developed by Copenhagen's renowned architecture and urban design firm Bjarke 
Ingels Group (BIG) to unite the city under one master plan that addresses the needs of the 21 stcentury.

Loop City is a regional master plan for the entire Øresund region which would connect Copenhagen with other regional cities like the cities of Helsingborg and Malmö in Sweden. The plan identifies 10 new challenges faced by Copenhagen with reasons for the challenges and proposes a solution to those problems.

Mobility: Betfer Place- The plan opted for creating a network of electric cars to increase the mobility. Charging station was proposed for these electric cars at rail stations and transit hubs for ease of accessibility. These electric car charging stations will be operated entirely on renewable energy.

Energy: Smart Grid- Loop City promoted the use of renewable energy in order to create a smart grid system. The plan included the use of solar collecting paving, wind farm, and solar panels to create a smart grid. With the use of smart appliances and proper demand management, the city plans to utilize both on-site and off-site produced energy efficiently.

Waste: Waste Suck- An underground network of waste collecting systems was proposed as an alternative to currently used garbage bin-based system. The "waste suck" will collect waste, sort the organic waste and use it for generating electricity. This electricity will be added to the smart grid and be used to charge electric cars.

Water: Living Machine- The plan integrates a wastewater cleaning system to turn wastewater into clean potable water. By creating a "living machine" with constructed wetlands, stormwater runoff will be naturally and attractively filtered. These wetlands will support a wide variety of local wildlife and plants creating a diverse ecosystem.

Global Climate Change: Flood Control- To mitigate the impact of global warming and minimize the risk of urban flooding, the plan included a network of canals placed throughout the city. The use of green roofs would act as a rainwater collector to prevent localized or widespread flooding.

Biodiversity: Hyper Nature- To promote biodiversity, the masterplan integrated a network of artificial swamps, wetlands, and marshes in the masterplan with the stormwater management system. The wetland will support an incredible range of flora and fauna and create a natural habitat for local species.

Industrialization: Micro Industries- There are many industrial buildings around the city representing the declining large-scale manufacturing sector. The plan proposed repurposing old industrial buildings into architectural attractions. To promote micro industries based on CNC and 3D printing technology, the plan integrated these cleantech industries within the city. 
Health: Health Track- Copenhagen has a great bicycling culture and excellent infrastructure that encourages walking and bicycle use. The Loop Plan further improves on the existing situation by integrating "smart" bike systems, bike-share services and bicycle storage facilities in the design. To discourage the use of the automobile, small scale plazas were designed around the transit hubs. By expanding public transit networks, people were encouraged to use public transportation rather than driving.

Food: Urban Farming- Loop City proposes small-scale urban farming to reduce the dependency on large scale food production. The urban farming will create new activities within the community and generate working spaces in the green strip. Food markets were proposed under the metro stations to unitize space. Organic wastes from urban farming will be used to generate biogas and electricity.

Migration: Regional Infrastructure- The masterplan will connect the entirety of the Øresund region by creating physical structures to link the cities of Denmark and Sweden within the region. This improved connectivity will promote ease of access between the two countries creating a regional transportation network.

The plan has two stages. The first stage will be implemented only within the city of Copenhagen. In the later phase, the plan proposes to provide a physical connection with the entirety of the Øresund region by connecting Malmö with Copenhagen. If implemented, the plan will be a great example of how new innovative technologies can be integrated to face the challenges of new millennia.

\subsection{Sustainable planning of Singapore}

The future of the world lies in its urban environment. More than half of the world population currently lives in cities and the number is ever-growing. This rapid influx of people creates possibilities, but it also creates new challenges. To create sustainable and manageable human spaces for the ever-growing city, the Urban Redevelopment Authority (URA) of Singapore came with the Singapore 2030 plan to ensure the thriving future of the city.

One of the greatest challenges Singapore faced was to ensure a constant safe supply of potable water. Singapore currently uses 2 billion liters of water daily. The most efficient source of freshwater is rain.

To capitalize on this resource, Singapore has created an extensive network of rivers and canal that channel rainwater to the 17 water reservoirs of the city. About 2/3 of the city is designated as a water catchment area which is around 400 square $\mathrm{km}$. Water that falls 
into a catchment area gets collected through this vast network of drainage lines, canals and rivers to ultimately get stored in a reservoir.

By prioritizing the water catchment system in the planning process, Singapore has ensured the preservation of its wetlands. With the changing weather pattern, it has become ever more important to manage the water retention areas properly to maximize the available rainwater.

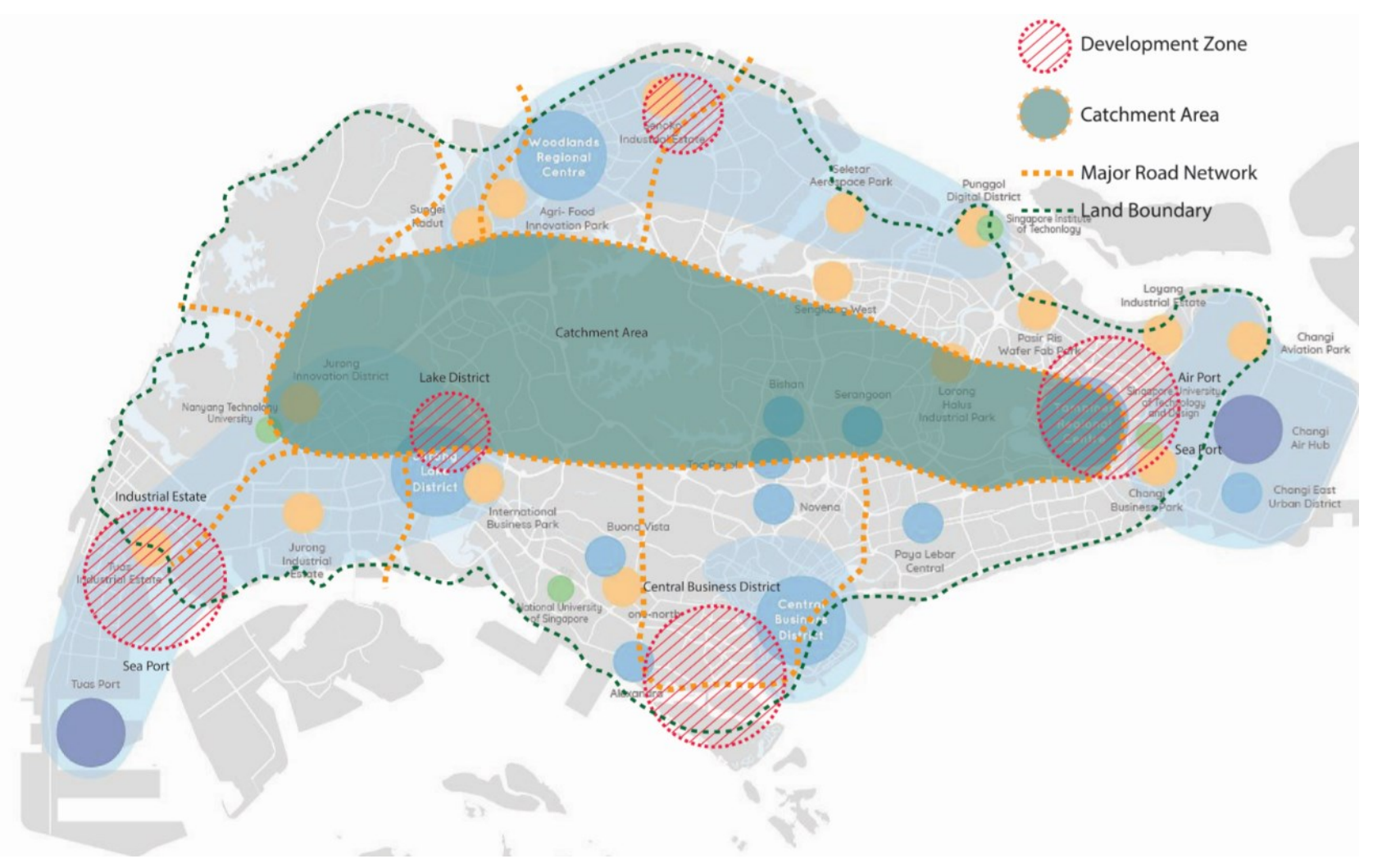

Figure 3.24: Development concept of Singapore around water catchment zone (Source: Author)

As a result, Singapore is one of the top livable cities in the world. Since becoming an independent country, Singapore prioritized long term comprehensive plans to ensure all future development needs. A series of strategies were developed to guide the sustainable development of Singapore. The main objectives of these plans were:

Economic: Sustain a robust and vibrant economy

Social: Provide a good quality of living and a sense of well-being for all

Environmental: Develop in an environmentally responsible manner

Land and sea: Optimize the limited land and sea space 


\section{Master plan of Singapore 2030}

Singapore came up with sustainable planning policies to ensure a livable environment for millions of people. Inspired by visionary plans and guided by advancements in technology, singapore dives deep into the latest innovations and technology being created and implemented to blaze a path into the City of the Future.

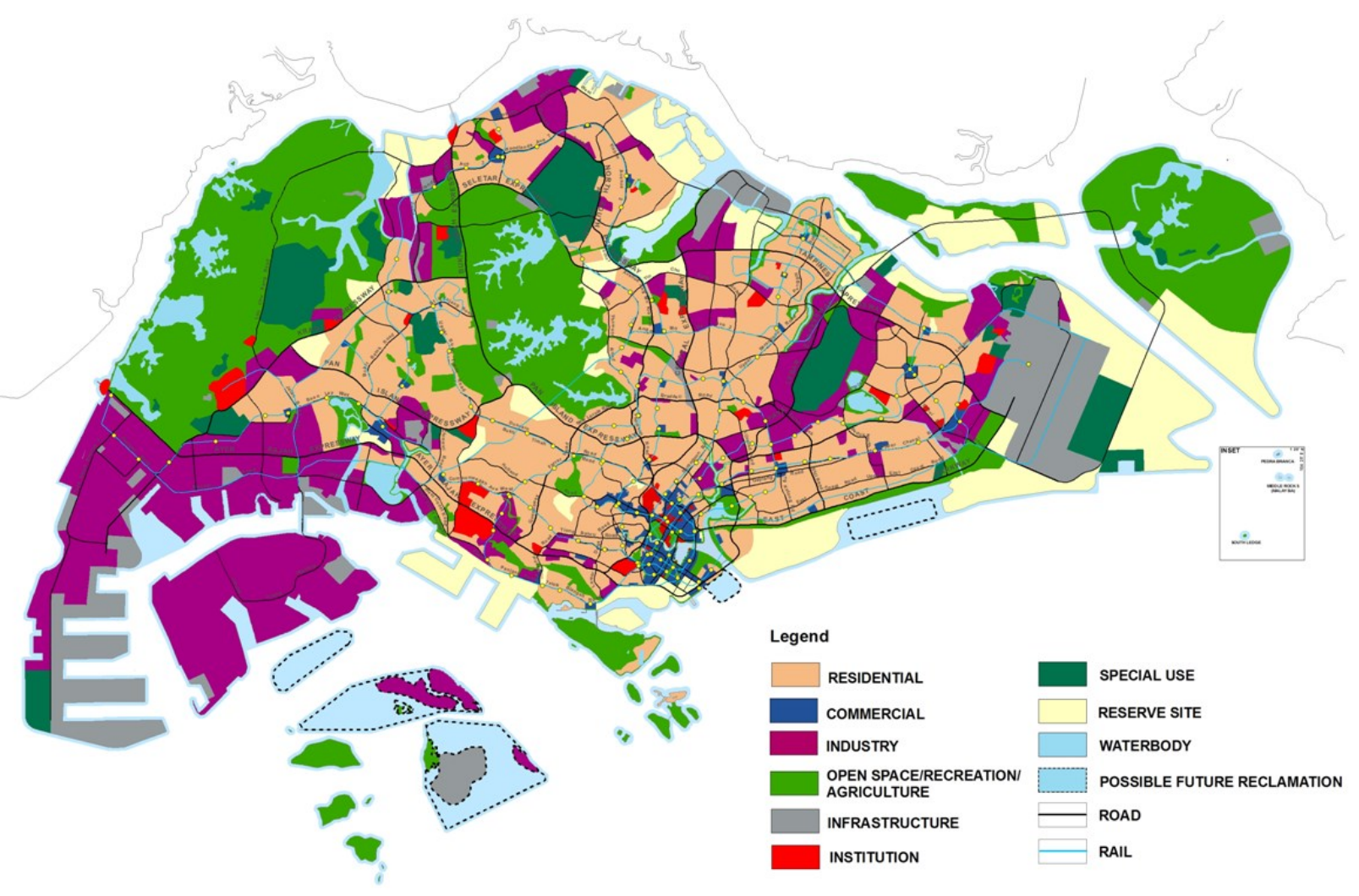

Figure 3.25: Land use plan of Singapore 2030 (Source: URA 2008)

The plan outlined the strategies to support the projected population and economic growth while ensuring a high-quality living environment for all Singaporeans. The main components of Singapore 2030 Master plan are:

Compact City: The compact planning strategy ensures the best utilization of available land in Singapore. Homes and amenities are designed around public transportation hubs to minimize the need for long-distance travel.

Housing for all: The Singapore housing development board plan to create more than 10,000 high rise housing units to provide affordable housing to all citizens of Singapore. By prioritizing high rise residential development, the city aims to create more ground-level open space and parks to integrate nature within the city environment. 
Quality living: By designing integrated parks, childcare centers, healthcare facilities and recreational spots within the housing block, the new development plan aims to make sure all basic amenities are easily accessible. The plan aims to improve public transport and road network and bring offices nearer to homes to reduce commuting.

Sustaining growth: Anticipating the need for critical infrastructures, the plan sets aside enough lands for future development. To maintain economic growth, the plan includes strategies for creating growth corridors and improve the seaports and airport.

Decentralization: The 1991 concept plan introduced regional centers to decentralize the city. By creating three new hubs to support the growing demand for commercial, retail and entertainment needs, the new plan proposes further decentralizing the city.

Going public: The plan aims to make Singapore a 45 min city by 2040. The land transport authority of Singapore proposes a more effective environment-friendly transportation system. The plan expands the bicycling network to promote active travel and minimize the carbon footprint of the city.

Play options: The city plans to provide access to greenery and parks within $400 \mathrm{~m}$ from every residence. To achieve this, the plan proposed to link up existing parks to make them bigger by creating an extensive green network within and around the city. The promenades, boardwalks, and bridges will create recreational opportunities and make the life of Singaporeans active and appealing.

Identity: To preserve the unique identity of Singapore, the masterplan proposes the policy of retention, restoration and careful repair of historic buildings around the city. By conserving different architectural styles from different periods, the plan aims to create a balance between heritage and development.

Resources: To strive towards creating a more livable city, the plan promotes the use of renewable energy while improving energy efficiency. The plan proposes to recycle $70 \%$ of the waste produced by the city and to reduce daily water consumption from 153 liters to 140 liters by 2030.

Climate change: Being a low lying densely populated city, Singapore is at high risk from the changing climatic conditions. To make the city more resilient to the impact of climate change, the masterplan proposes 0.8 ha of green park space for every 1000 citizens. By increasing green roofs in Highrise buildings to 50 ha, the city will be able to use the rainwater more efficiently. The plan also incorporated 900 ha of water reservoirs and 100 $\mathrm{km}$ recreational waterway to increase water resiliency and promote biodiversity.

Living Lab: To address new challenges of future cities, Singapore plans to emerge as a living laboratory by becoming the cradle of new ideas, pioneering technologies, and smart solutions. 


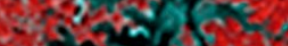

- 450

Hing

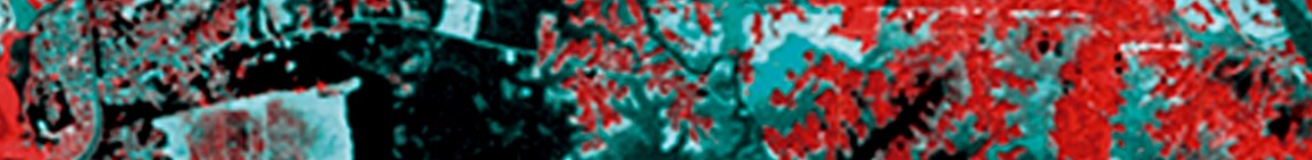

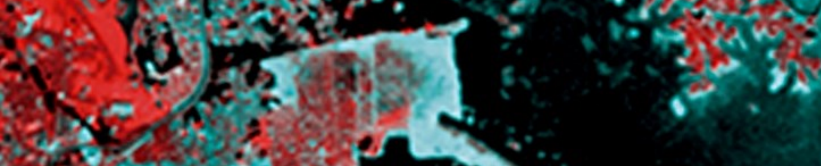
inces

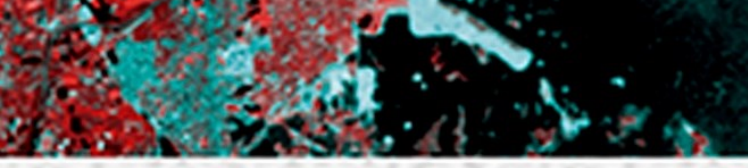

k
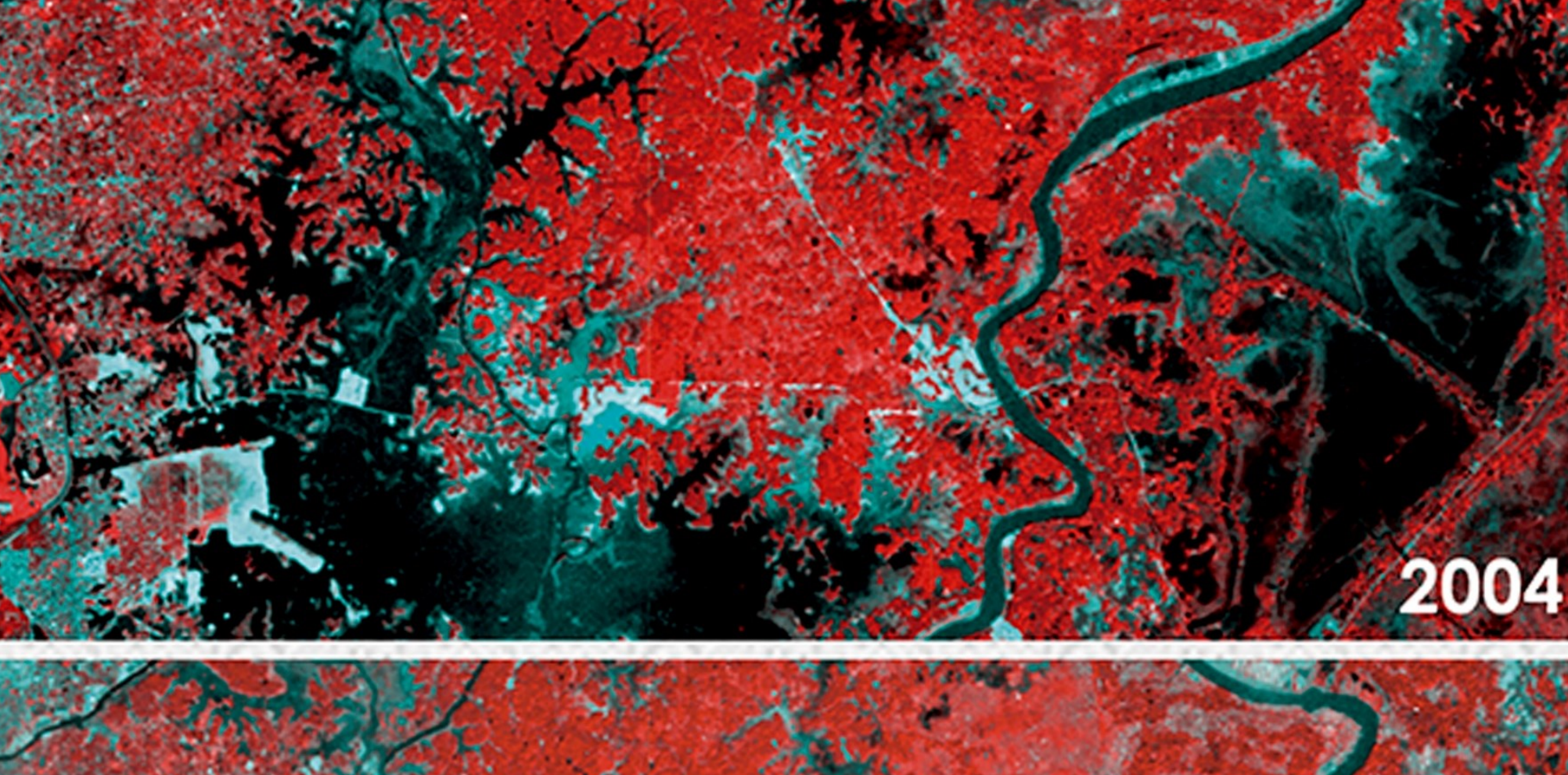

3.18

icis

Sxit:

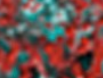
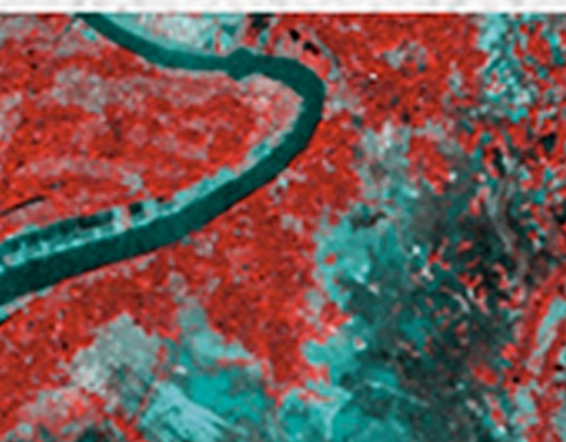

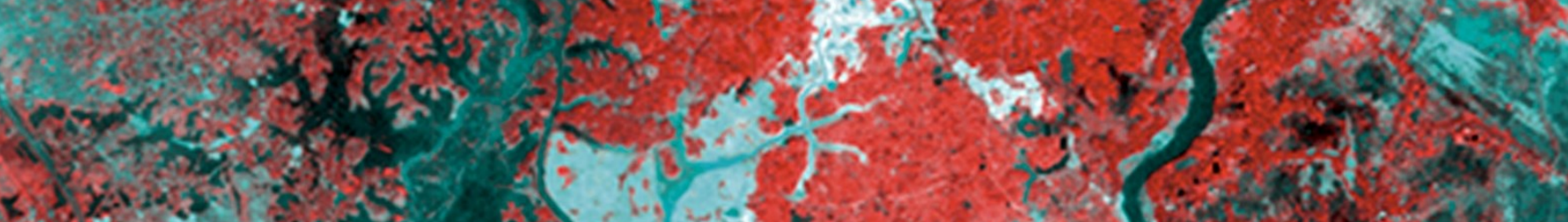

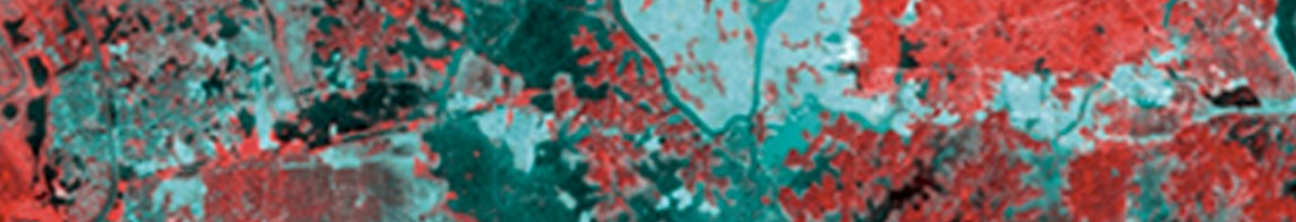

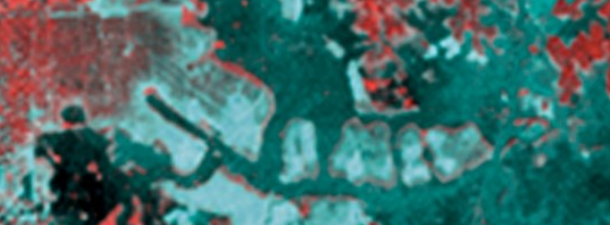

(4) 18

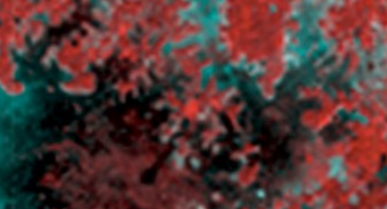

Tesa

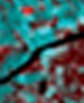

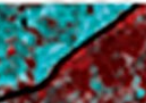

a) 3

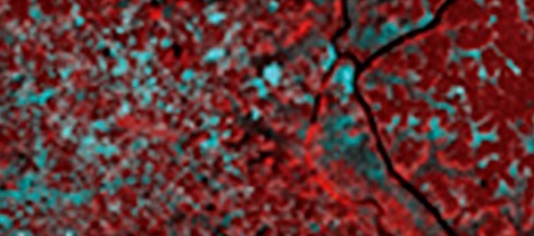

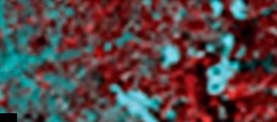

$\frac{2}{3}$

(3)

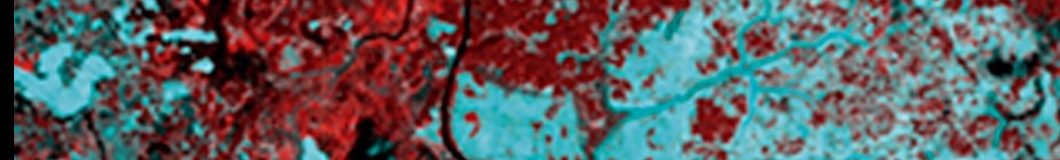

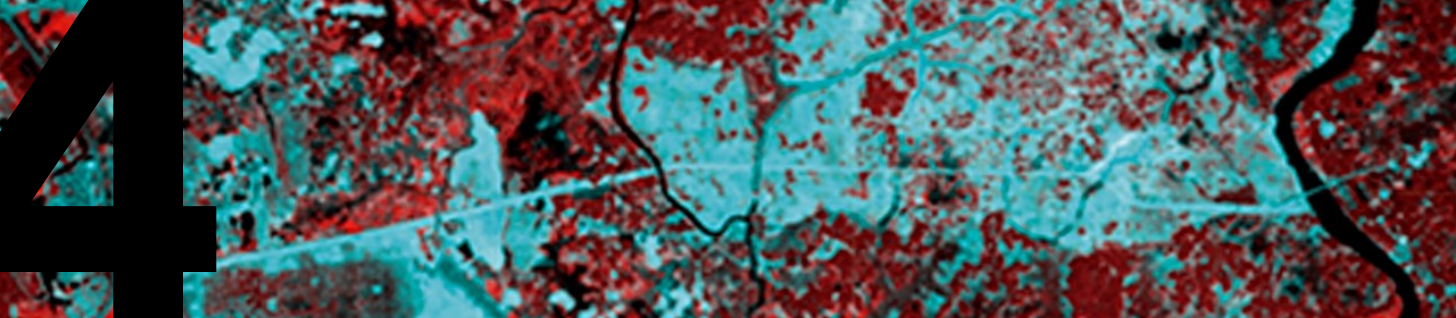

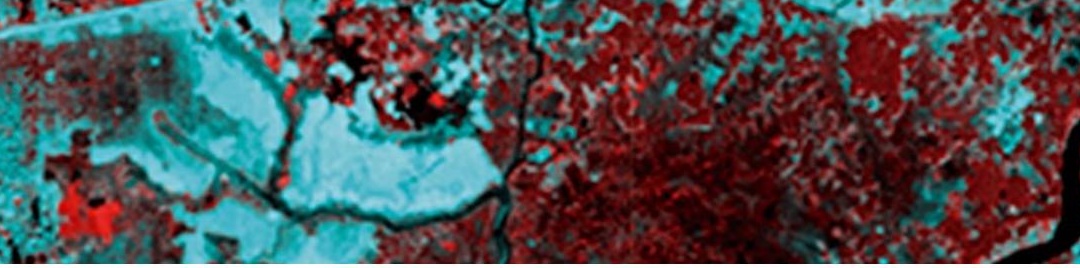

2008

- ㄴ:

.

2011 


\section{Chapter 4 Site Analysis/Geo-analysis}

\subsection{Weather Pattern of Purbachal}

The climate of Bangladesh can be characterized as a tropical savanna climate or tropical wet and dry climate that corresponds to the Köppen climate classification categories Aw (for a dry winter) and As (for a dry summer) (Hess et al. 2011). The region has seasonal fluctuations in precipitation, higher temperatures and humidity. According to regional climatic conditions, Bangladesh can be divided into seven distinct climatic zones. Purbachal is within the mid-south region (Figure 4.1), a transitory zone between the South-eastern, North-western and South-western.

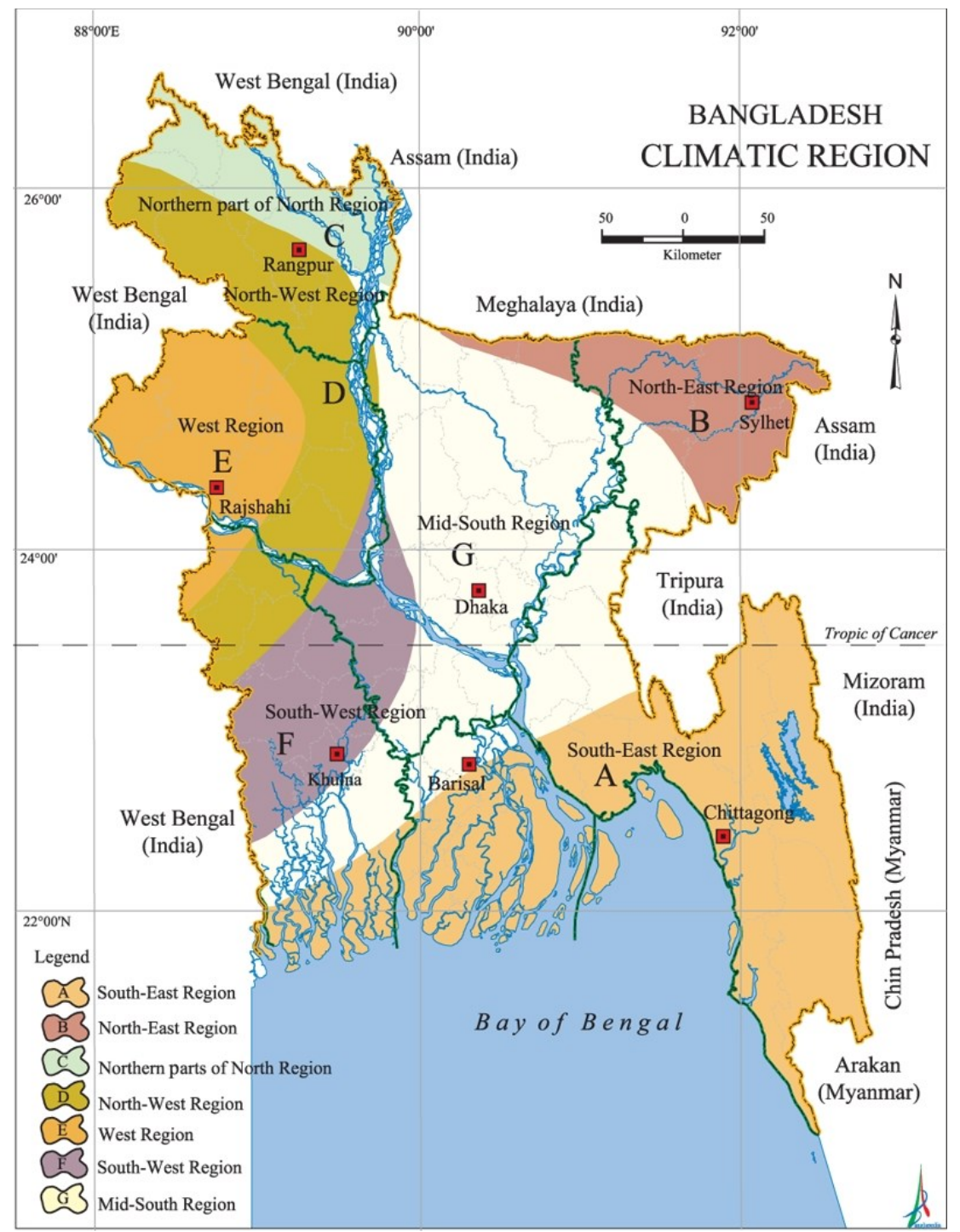

Figure 4.1: Climatic zones of Bangladesh (Source: Banglapedia, National Encyclopedia of Bangladesh. 2018) 
Purbachal and adjacent region having a tropical savanna climate tends to either see less rainfall than a tropical monsoon climate. As a result, the region has more pronounced dry season. But during rainy season, the rainfall is abundant, being above $1900 \mathrm{~mm}$, which can cause prolonged flooding.

The Stereographic Diagram illustrates the variation in the sun's movement in relation to latitude. The relative position of the sun act as a major factor in the temperature experienced. From the diagram, it is observed that the sun position is at the highest point during the month of June giving rise to higher temperature (Figure 4.2).

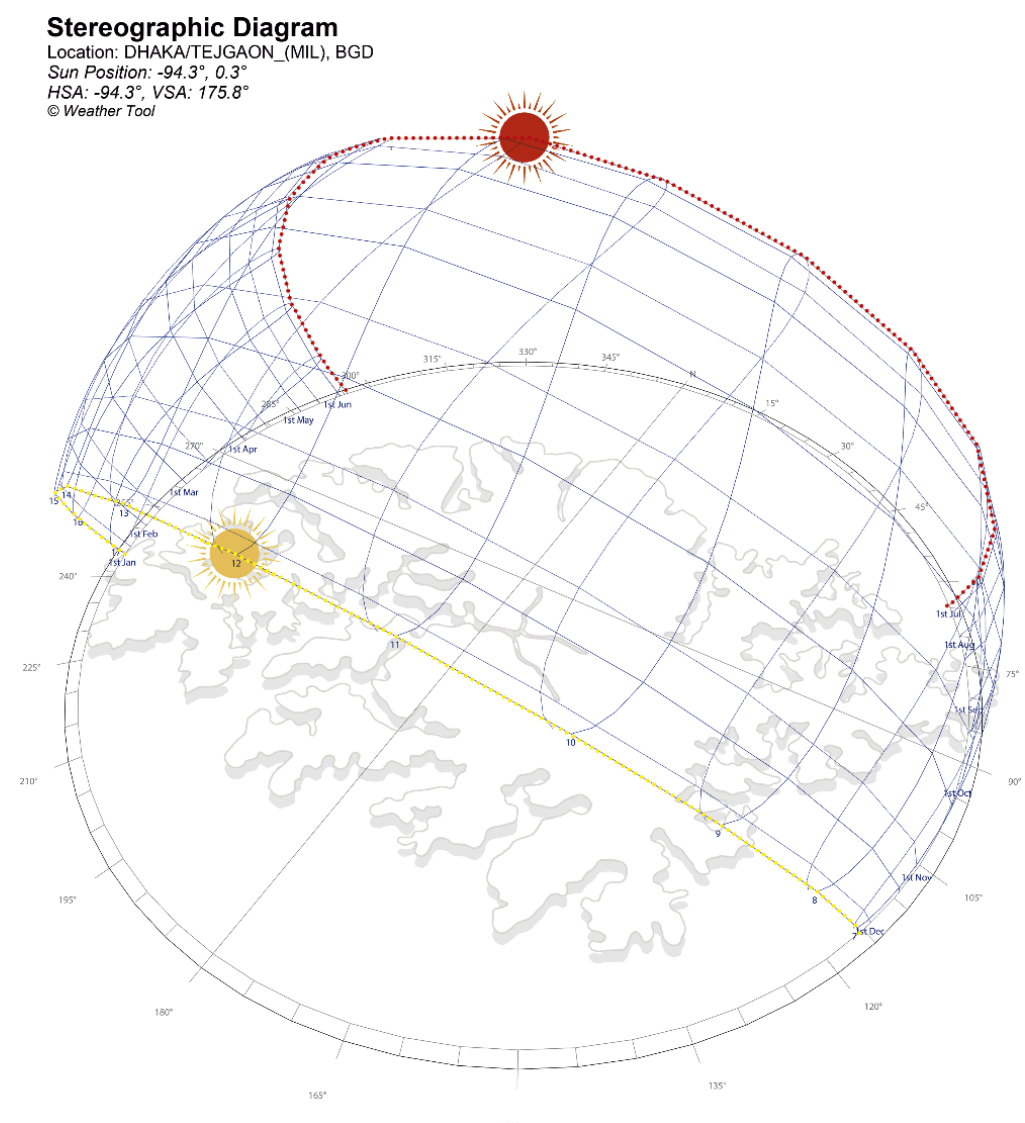

Figure 4.2: Stereographic Diagram of Purbachal

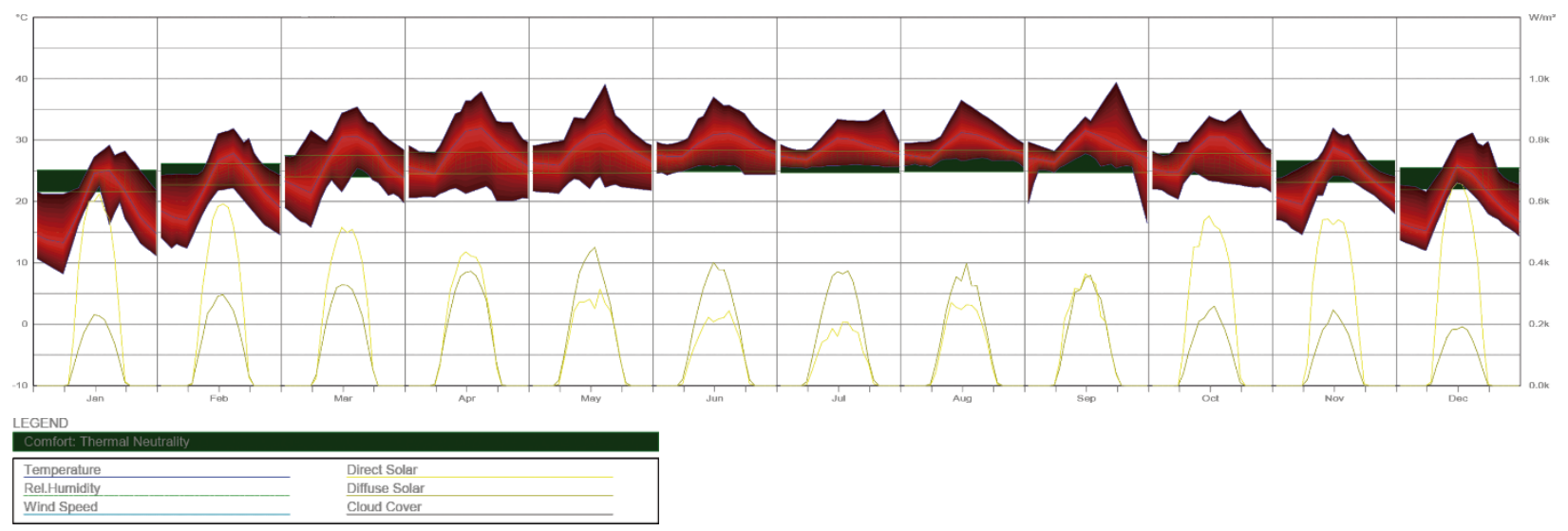

Figure 4.3: Monthly diurnal average 
There are three different seasons in the region. The dry season lasts from October to March. January is the coldest month, when the normal temperature for most of the country is around $10^{\circ} \mathrm{C}$ (BBS, 2016). The warm, wet season lasts from March to June. As the winter season progresses into the pre-monsoon hot season, temperature rises, reaching the maximum in April between $30^{\circ} \mathrm{C}$ and $40^{\circ} \mathrm{C}$ (Figure 4.3). April is this warmest month in most parts of this region. The cold, wet rain season from starts from June to October.

\section{Weekly Summary}

Location: DHAKA/TEJGAON_(MIL), BGD $\left(23.8^{\circ}, 90.4^{\circ}\right)$

Average Temperature $\left({ }^{\circ} \mathrm{C}\right)$

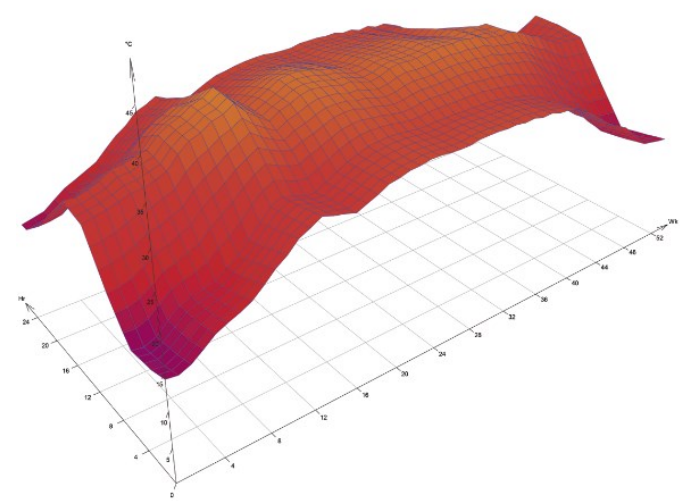

\section{Average Cloud Cover (\%)}

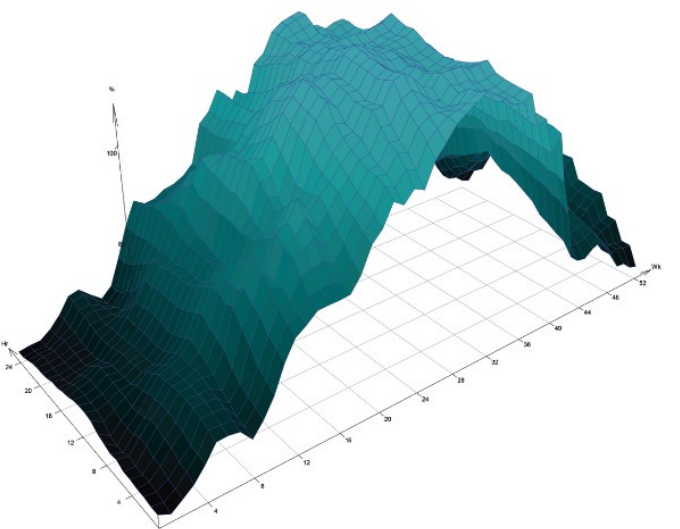

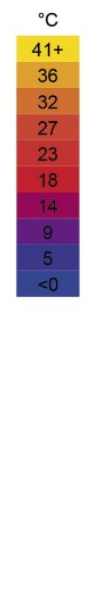
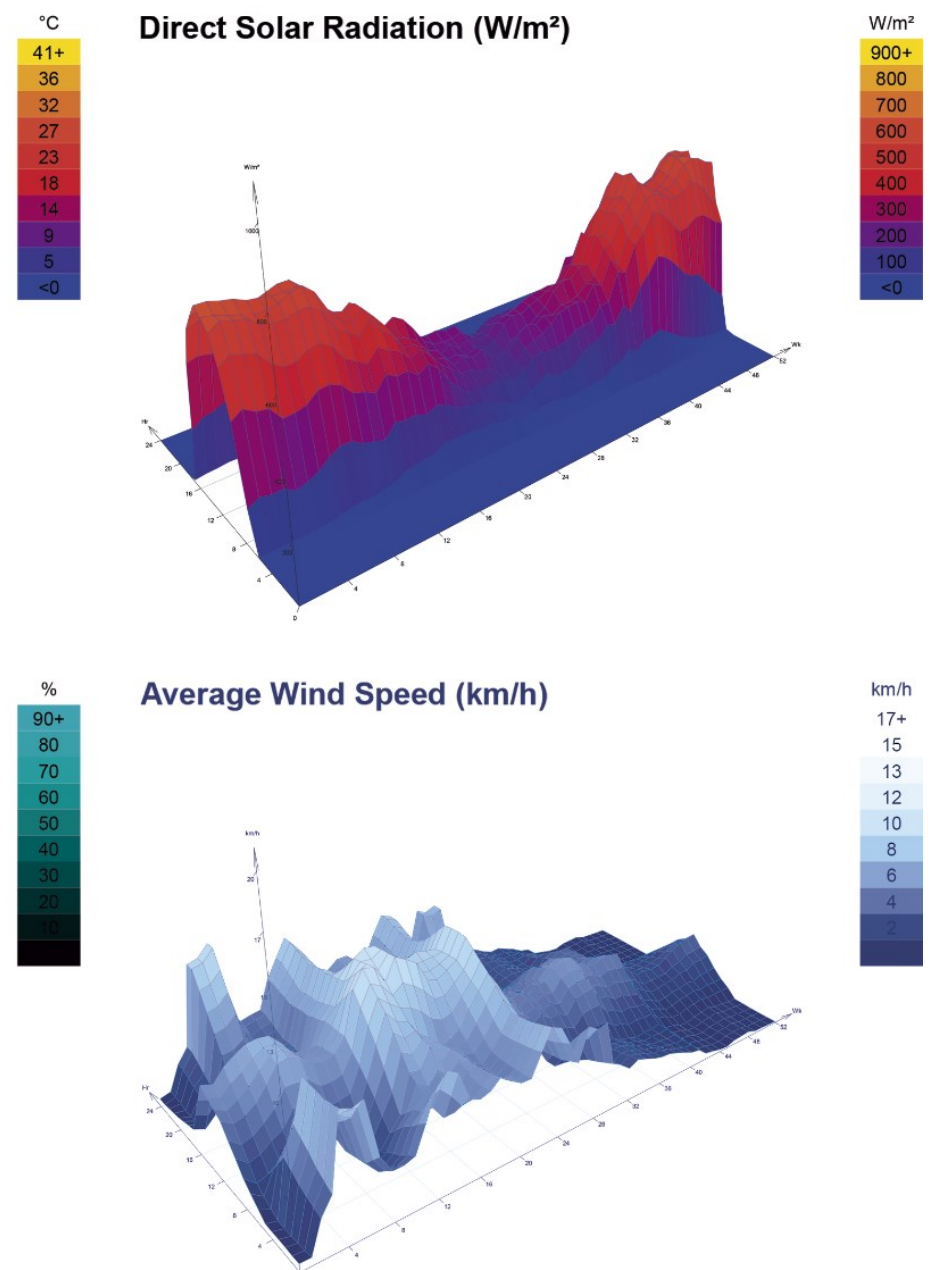

Figure 4.4: Weekly summary of Average Temperature, Direct Solar Radiation, Average Cloud Cover, Average Wind Speed

The region sees a higher cloud coverage during the month of June to October. Due to the cloud cover, the direct solar radiation decreases during this period, but the average temperature remains high creating a moist, hot and humid conditions (Figure 4.4).

Most of the overall yearly rain, nearly $80 \%$ of around $1900 \mathrm{~mm}$ occurs between June to September (Ahammed et al. 2014). Rainfall is the single most dominant element climate of this region. As a result, the region frequently suffers from seasonal flooding. 
The geographical location and its geomorphic conditions have made the region easily vulnerable to natural disasters seasonal floods, norwesters, and river bank erosion (Ali 1996). During any major flood, two-thirds of land can be submerged with floodwater, and many settlements can be drowned. The monsoon arrives between late May and early June, starting from the south-east. It brings more compact cloudiness, high humidity even during the day (Figure 4.5). Due to frequent rains, the temperature decreases to $30-32^{\circ} \mathrm{C}$ $\left(86-90^{\circ} \mathrm{F}\right)$ during the day, but remains high at night, about $25^{\circ} \mathrm{C}\left(77^{\circ} \mathrm{F}\right)$ due to heavy cloud cover.

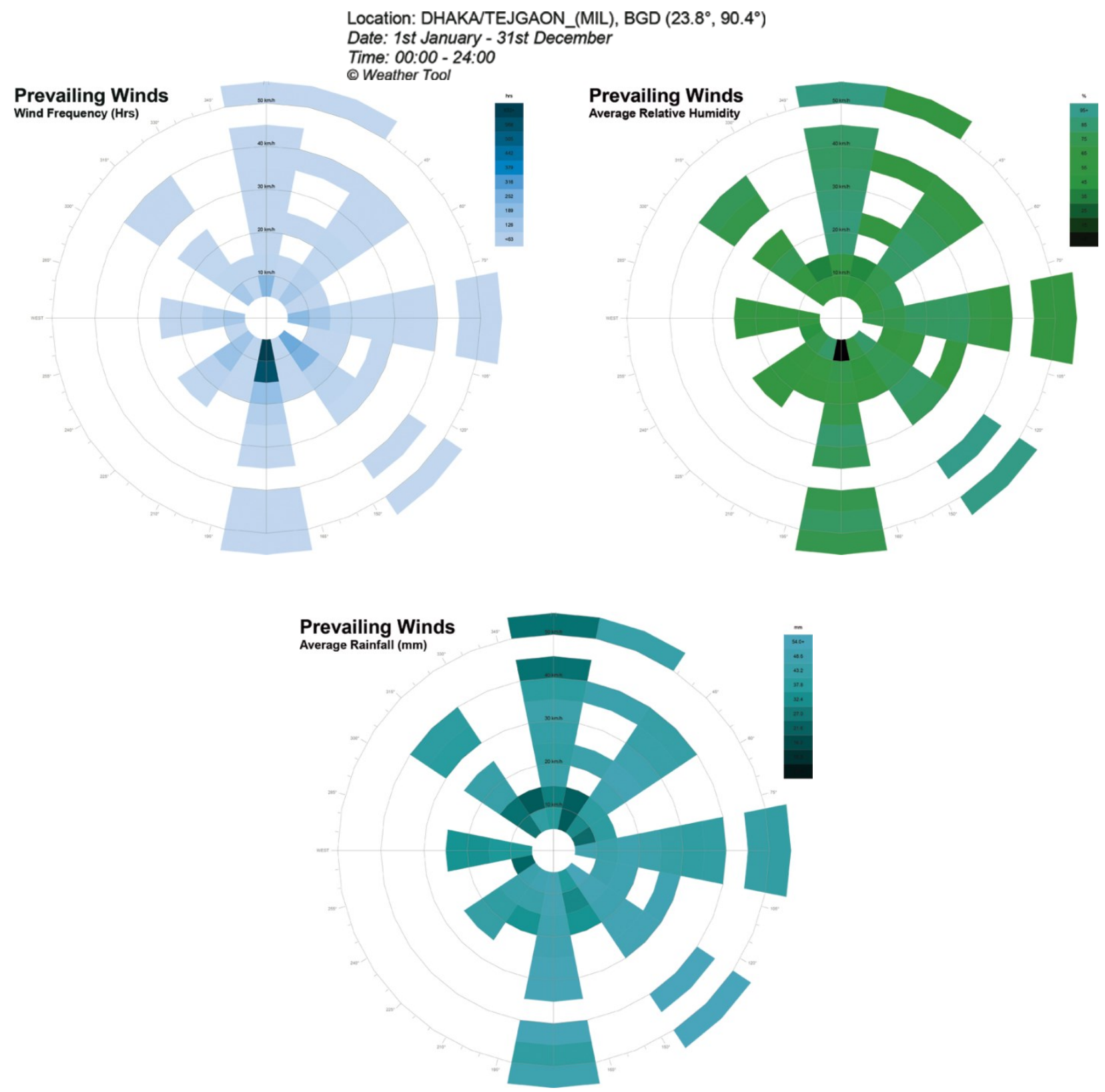

Figure 4.5: Prevailing wind in relation with Wind Frequency and Average Relative Humidity 


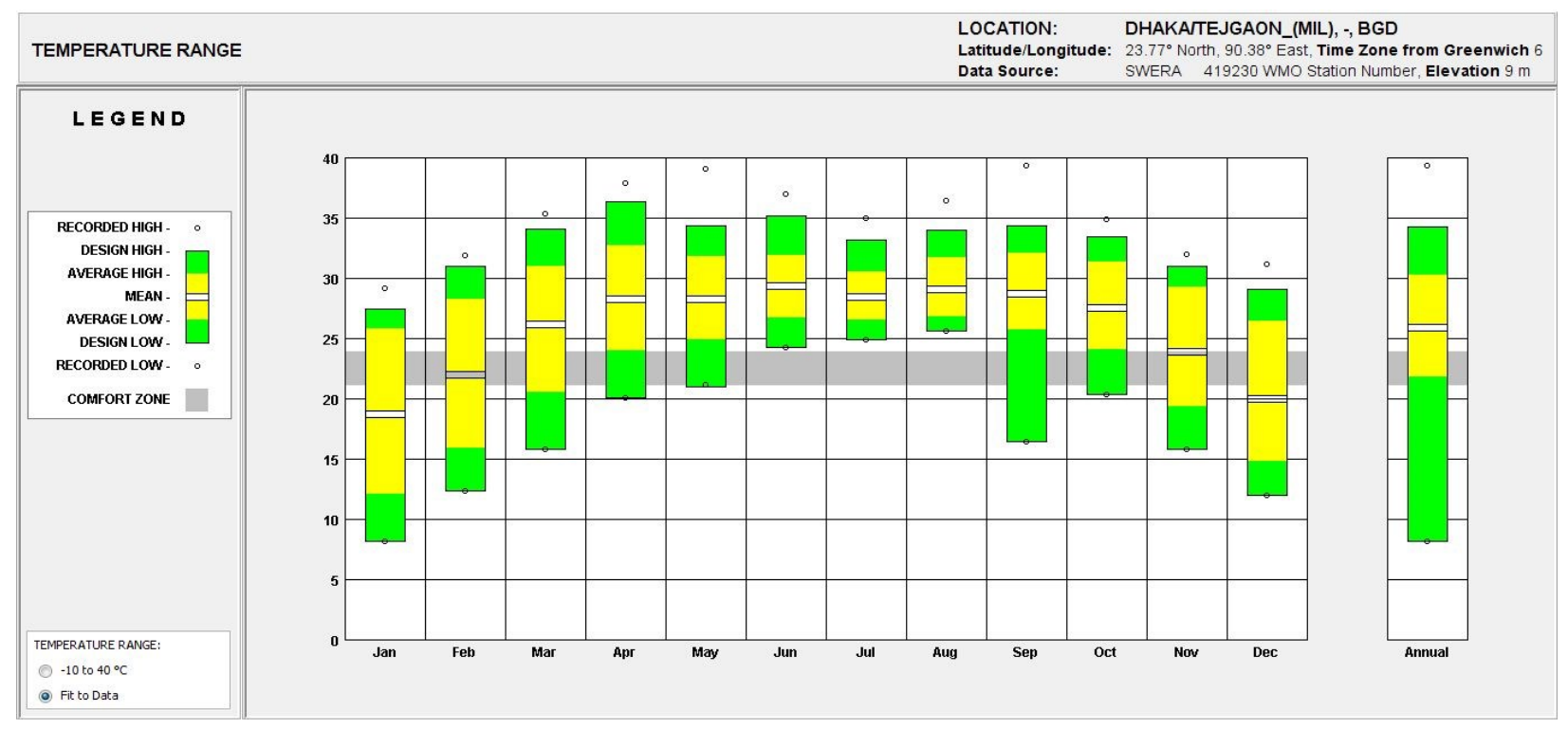

Figure 4.6: Temperature range chart

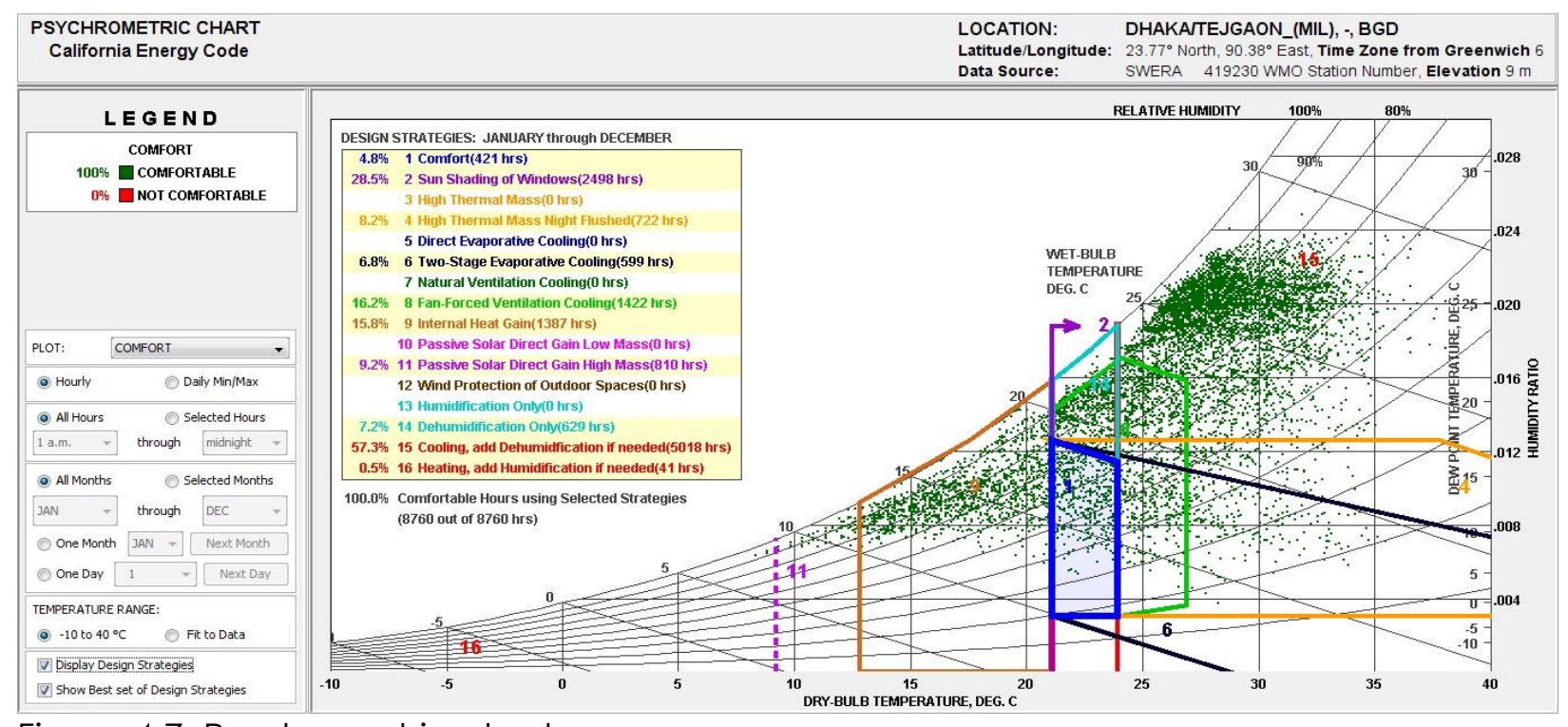

Figure 4.7: Psychrometric chart

The physical and thermodynamic properties of the region is presented through the Psychrometric chart (Figure 4.7). The chart graphically represents weather elements such as wind direction, wind velocity, dry and wet bulb temperature, humidity, rainfall etc. of an area and how these elements impact the human comfort.

The Psychrometric chart serves as a guideline for designing the area according to its climatic needs. Being situated in the warm humid temperature zone, it is observed that $57.3 \%$ time of a year is needed cooling and dehumidification for designing any public space. $28.5 \%$ time of a year needs shade in outdoor place to provide protection from direct sunlight. Therefore, maximizing the use of prevailing wind and creating shaded space can be major strategies to make outdoor spaces comfortable. By providing natural water body and using indigenous plants, urban microclimate can be modified to create a more comfortable outdoor experience. 


\subsection{Land Transformation of Purbachal}
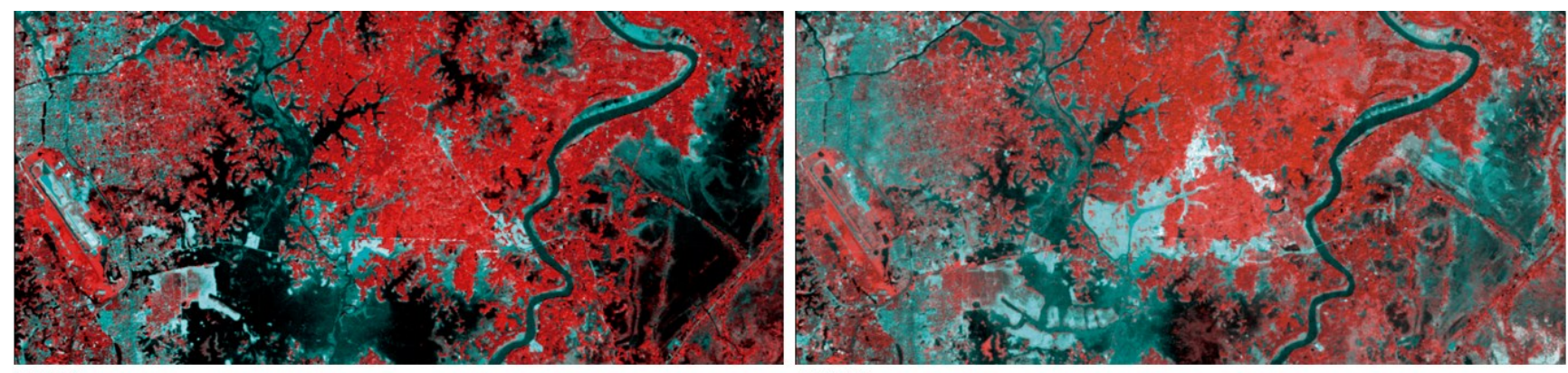

2004

2008
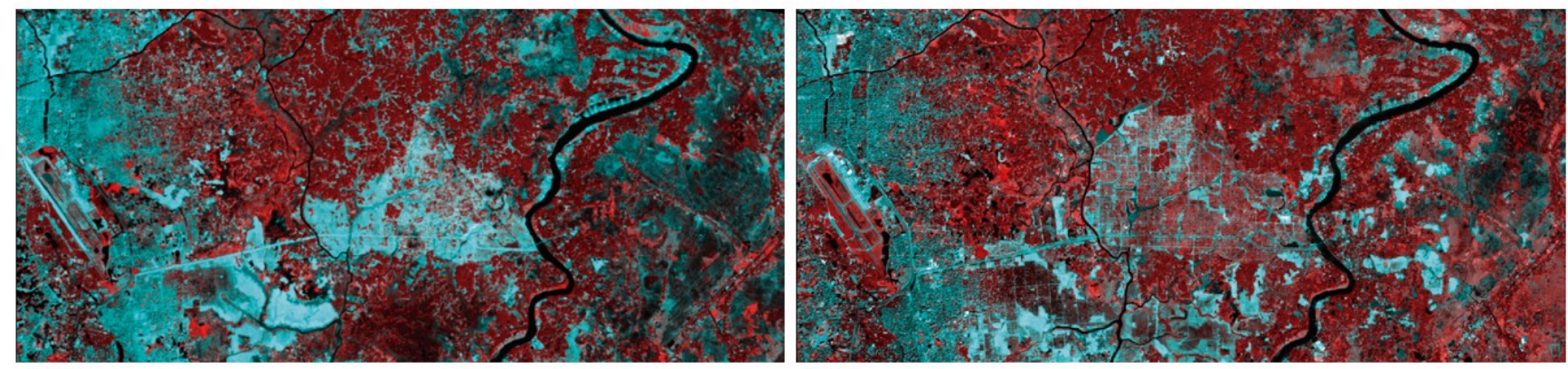

2011

2019

Figure 4.8: Land transformation of Purbachal from 2004 to 2019 (image source: LANDSAT, SENTINEL 2)

To assess the changing urban land use and land cover (LULC) conditions of the region, LANDSAT TM collections land surface reflectance (MSS, TM and ETM+) and SENTINEL 2 WMS images from path 021, row 032 between the year 2004 to 2020 were analyzed. As the primary purpose of the study was to analyze the land cover transformation pattern, only the images under relatively clear sky condition were acquired.

With the US Geological Survey's Earth Resource Observation Systems (EROS) Data Center the acquired images were processed to make corrections for radiometric and geometric distortions. The images were georeferenced to Universal Transverse Mercator coordinate system, Zone 16 North. Then additional spatial data depicting spatial attributes of different zones were added by using GIS polygon layers.

The study was conducted in three phases. The first phase false color composition images from 2004 to 2019 was compared to highlight the changes in urban land use and land cover (LULC). The seasonal land transformation due to flood was further analyzed to estimate the areas of wetland, semi-wetland and flood free zones. Secondly, the satellite images from 2004 and 2020 was analyzed to classify different types of land use. For this purpose, supervised and unsupervised classification methods were used. The results were compared with reference images and it was observed that supervised classification provided better results in identifying different types of landcovers. And finally, the accuracy statement of the resulted land classification images was conducted. 


\subsection{Changing Landform due to Water Level Fluctuation}

The satellite images from 2004 was analyzed to identify the land transformation pattern during a major flood event. The amount of flood free land was calculated to assume probable developable area.

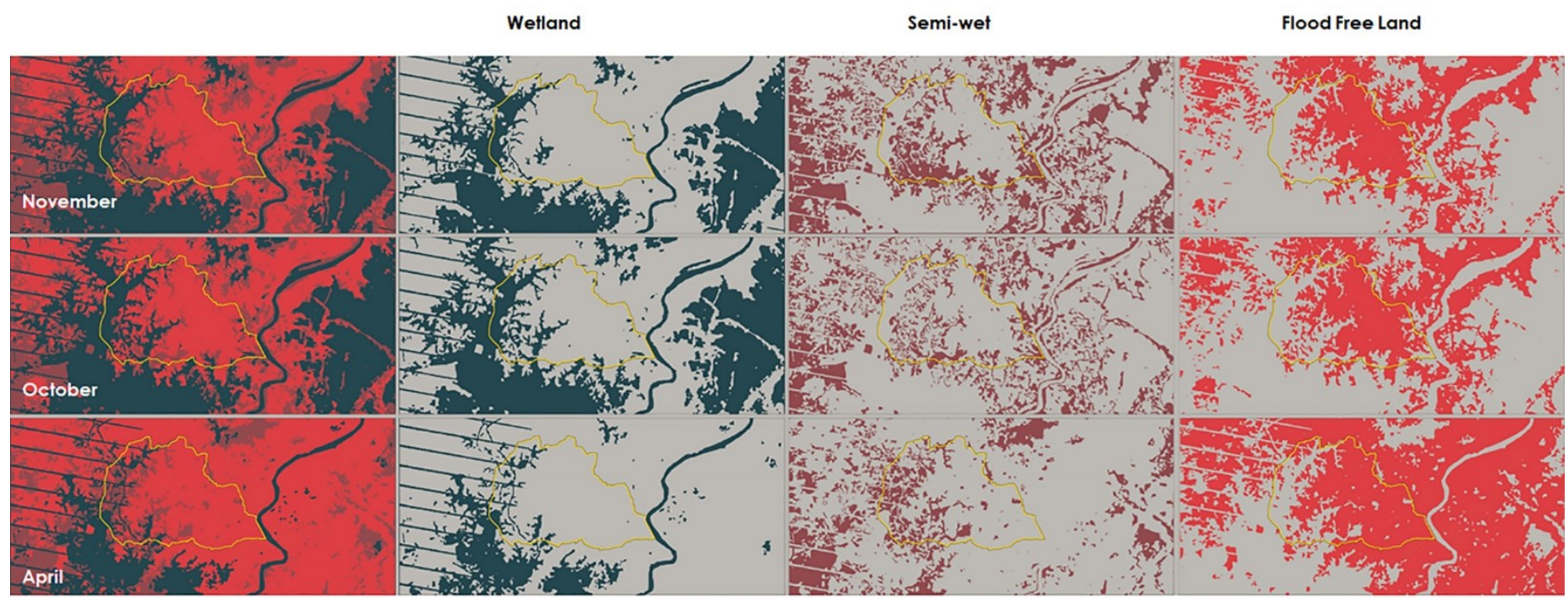

Figure 4.9: Transformation of landform due to flooding

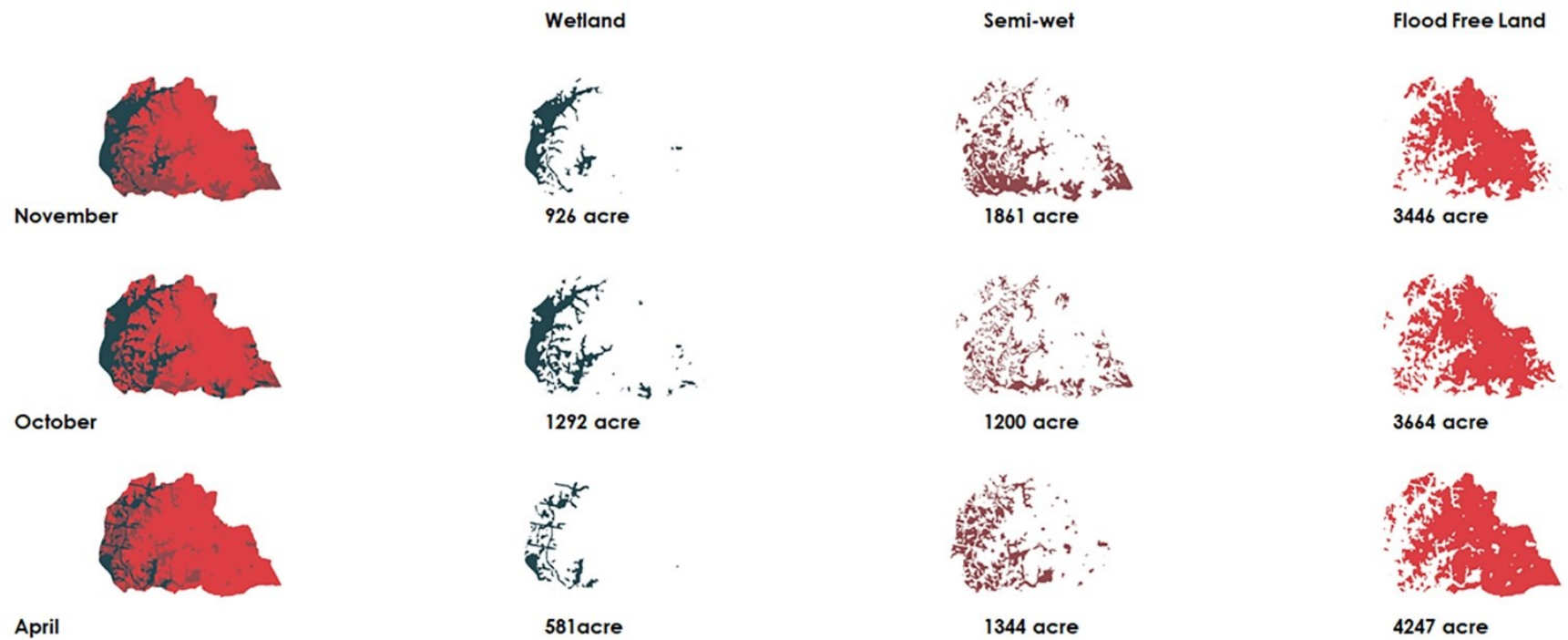

Figure 4.10: Area comparison between different types of land form 


\subsection{Unsupervised Classification}

In the next phase, unsupervised classification was carried out to highlight the changes in

land cover from pre-development to post development phase.

\section{Unsupervised classification-2004}

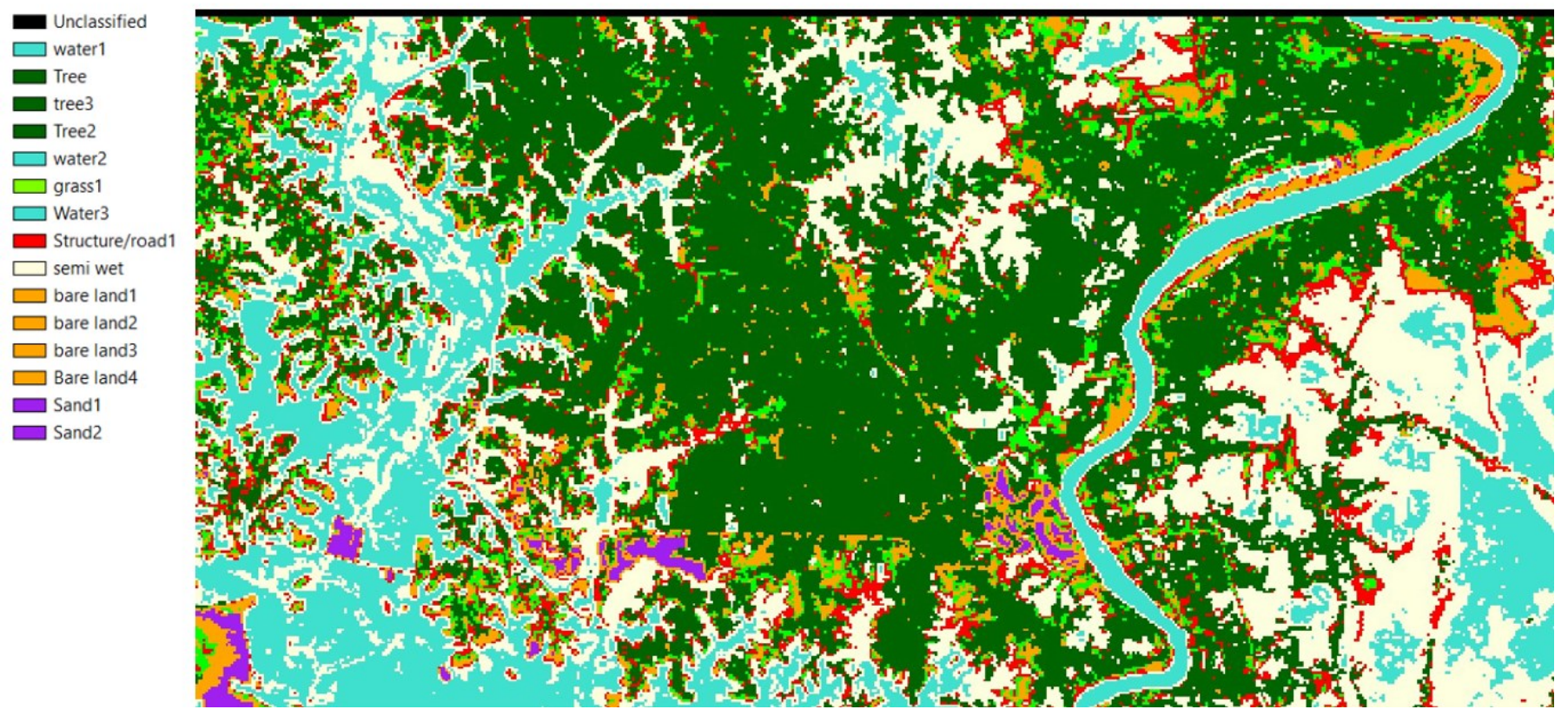

Figure 4.11: Unsupervised classification of pre-development landform

\section{Unsupervised classification-2020}
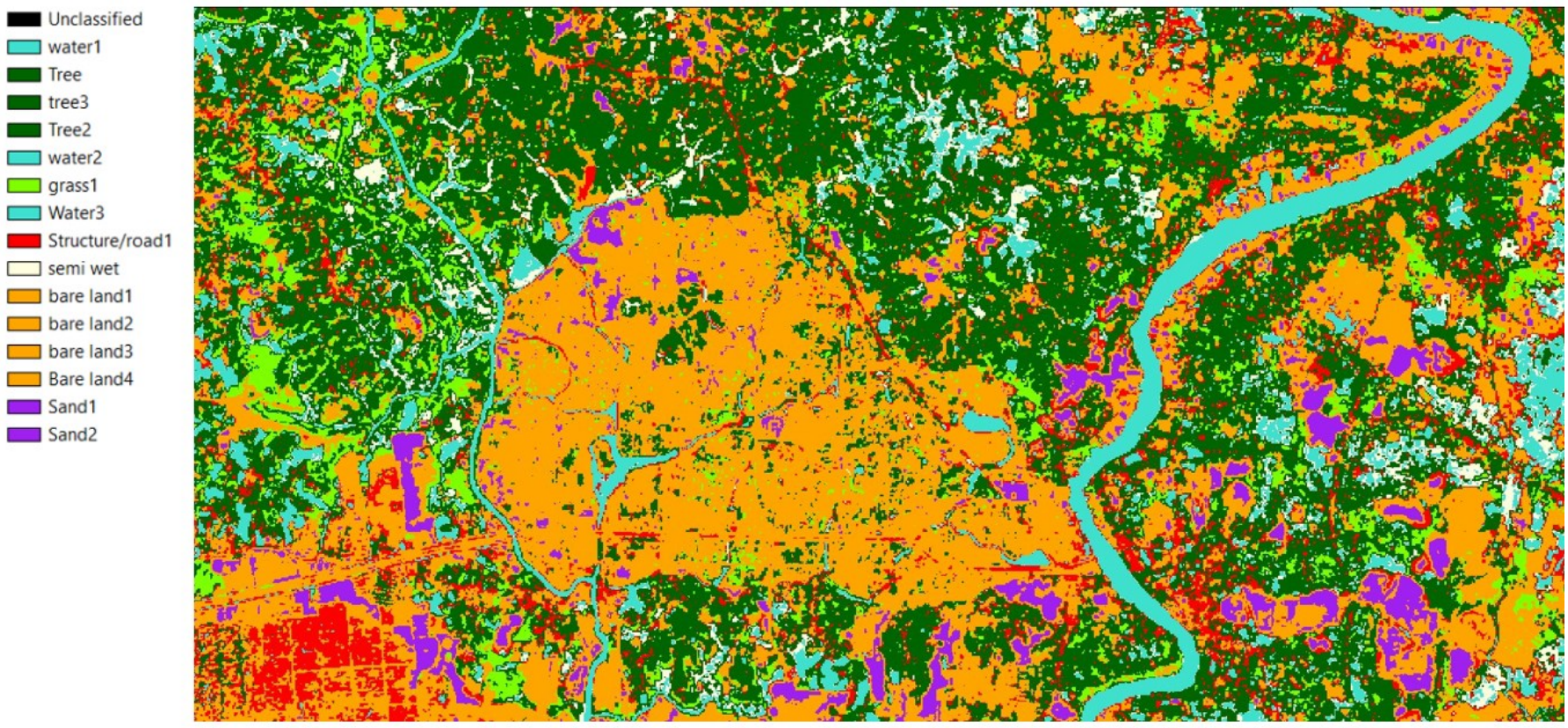

Figure 4.12: Unsupervised classification of post-development landform 


\subsection{Supervised Classification}

The results of unsupervised classification overestimated the amount of structural and bare land cover and failed to properly identify the sand filled areas. To create a more accurate land cover map, supervised classification was carried out.

Supervised classification-2004

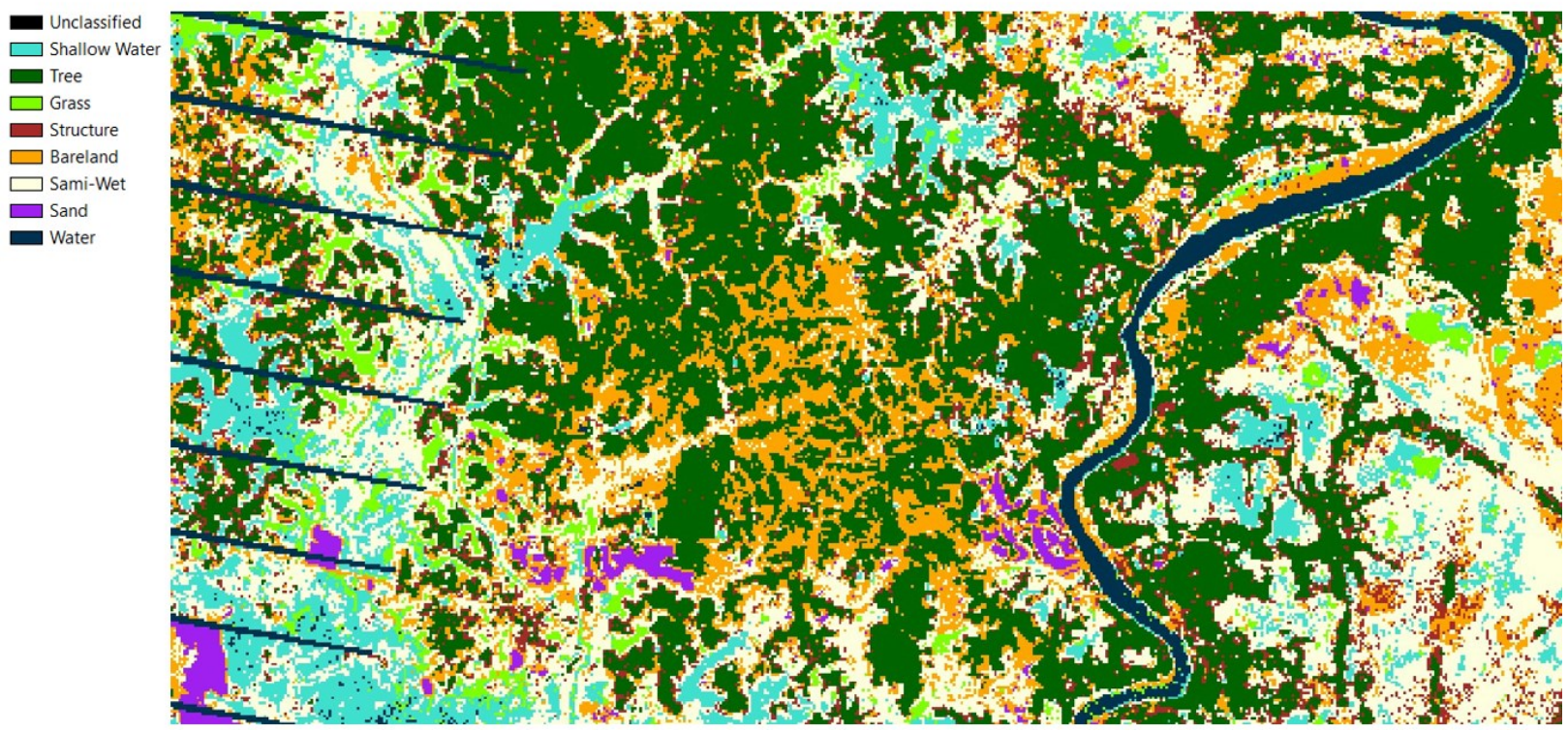

Figure 4.13: Supervised classification of pre-development landform

\section{Accuracy Statement of Supervised classification-2004}

Sample size based on multinomial distribution:

\begin{tabular}{|c|c|c|c|c|c|c|}
\hline & \multicolumn{3}{|c|}{ Enter parameters in these columns } & & \multicolumn{2}{|c|}{ Calculatio Result } \\
\hline & $\begin{array}{l}\text { Number of } \\
\text { Classes }\end{array}$ & $\begin{array}{l}\text { Largest } \\
\text { Proportion of } \\
\text { Class } i\end{array}$ & $\begin{array}{l}\text { Confiden } \\
\text { ce level }\end{array}$ & Precision & $x^{2}$ & $\begin{array}{l}\text { Sample } \\
\text { Size }\end{array}$ \\
\hline & k & $\Pi \mathrm{i}$ & \% (e.g., 95 & bi (e.g., 5\%) & $B$ & \\
\hline 2004 & & $35 \%$ & $90 \%$ & $10 \%$ & 6.238533 & 142 \\
\hline
\end{tabular}

\begin{tabular}{|c|c|c|c|c|c|c|c|c|c|}
\hline & & & Reference Data & & & & & & \\
\hline Classified Data & Shallow Water & Tree & Grass & Structure & Bareland & Sami-Wet & Sand & Water & \\
\hline 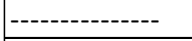 & ---------- & |---------- & ---------- & ---------- & ---------- & ---------- & ---------- & ---------- & \\
\hline Shallow Water & 14 & 0 & 0 & 0 & 0 & 0 & 0 & 0 & 14 \\
\hline \begin{tabular}{|l} 
Tree \\
\end{tabular} & 0 & 56 & 0 & 0 & 0 & 0 & 0 & 0 & 56 \\
\hline Grass & 1 & 0 & 4 & 0 & 0 & 3 & 0 & 1 & 9 \\
\hline \begin{tabular}{|l|} 
Structure \\
\end{tabular} & 0 & 0 & 0 & 2 & 0 & 2 & 0 & 0 & 4 \\
\hline Bareland & 0 & 2 & 3 & 0 & 11 & 2 & 1 & 0 & 19 \\
\hline Sami-Wet & 0 & 0 & 1 & 0 & 0 & 27 & 1 & 0 & 29 \\
\hline Sand & 0 & 0 & 0 & 0 & 0 & 0 & 3 & 0 & 3 \\
\hline Water & 0 & 0 & 0 & 0 & 0 & 0 & 0 & 8 & 8 \\
\hline Total & 15 & 58 & 8 & 2 & 11 & 34 & 5 & 9 & 142 \\
\hline
\end{tabular}


For the accuracy statement, the number of samples needed to evaluate the classification accuracy for a classification of 5 classes, $90 \%$ confidence and $10 \%$ precision was estimated. Multinomial distribution method was followed to calculate the sample size (Jensen, 2016). By using Equalized Random distribution parameters, 142 points were generated. Next, the points were interpreted for their land class and an accuracy report was generated. From the confusion matrix, it can be observed that the land cover class 'Grass' and 'Structure' was wrongly classified in some cases, and therefore had a lower user's accuracy.

\begin{tabular}{|l|r|l|l|r|}
\hline Producer's Accuracy: & Percentage & & User's Accuracy: & Percentage \\
\hline Shallow water & $93.3 \%$ & & Shallow water & $100.0 \%$ \\
\hline Tree & $96.6 \%$ & & Tree & $100.0 \%$ \\
\hline Grass & $50.0 \%$ & & Grass & $44.4 \%$ \\
\hline Structure & $100.0 \%$ & & Structure & $50.0 \%$ \\
\hline Semi wet & $100.0 \%$ & & Semi wet & $57.9 \%$ \\
\hline Bare land & $79.4 \%$ & & Bare land & $93.1 \%$ \\
\hline Sand & $60.0 \%$ & & Sand & $100.0 \%$ \\
\hline Water & $88.9 \%$ & & Water & $100.0 \%$ \\
\hline
\end{tabular}

\begin{tabular}{|l|l|l|l|l|r|}
\hline $\mathrm{N}=$ & 142 & & Landform & Area (ha) & Percentage \\
\hline $\mathrm{d}=$ & 125 & & Shallow Water & 1101.24 & $8.2 \%$ \\
\hline $\mathrm{q}=$ & 4820 & & Tree & 4729.14 & $35.3 \%$ \\
\hline & & & Grass & 435.15 & $3.2 \%$ \\
\hline Kappa Estimation & $84.3 \%$ & & Structure & 905.13 & $6.8 \%$ \\
\hline & & & Sami-Wet & 3555.45 & $26.6 \%$ \\
\hline & & & Bare land & 1981.35 & $14.8 \%$ \\
\hline Overall accuracy & $88.0 \%$ & & Sand & 194.67 & $1.5 \%$ \\
\hline & & & Water & 487.62 & $3.6 \%$ \\
\hline Foody 1992 statistic & $65.8 \%$ & & Total & 13389.75 & $100 \%$ \\
\hline
\end{tabular}

Table 1: Accuracy Statement of pre-development landform Supervised classification

From the accuracy statement, it is observed that the classification worked well in most of land form. The kappa statistics was 84.3 which suggested that the map was not a result of random classification. The overall map accuracy was 88 . The map performed quite well in identifying the trees and bare land and differentiated between areas of shallow water and water. 


\section{Supervised classification-2020}
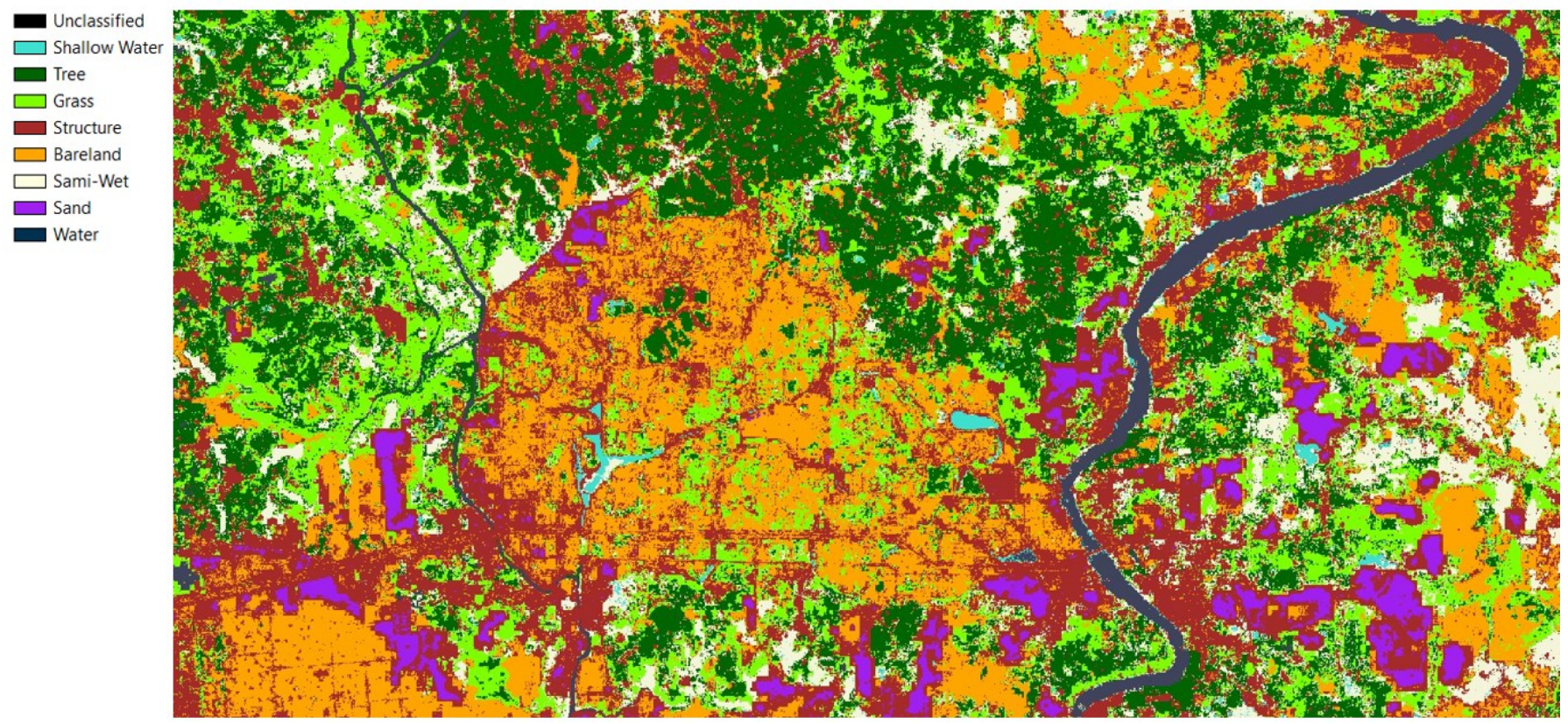

Figure 4.14: Supervised classification of post-development landform

\section{Accuracy Statement of Supervised classification-2020}

Sample size based on multinomial distribution:

\begin{tabular}{|c|c|c|c|c|c|c|}
\hline & \multicolumn{3}{|c|}{ Enter parameters in these columns } & & \multicolumn{2}{|c|}{ Calculatio| Result } \\
\hline & $\begin{array}{l}\text { Number of } \\
\text { Classes }\end{array}$ & $\begin{array}{l}\text { Largest } \\
\text { Proportion of } \\
\text { Class } i\end{array}$ & $\begin{array}{l}\text { Confiden } \\
\text { ce level }\end{array}$ & Precision & $x^{2}$ & $\begin{array}{l}\text { Sample } \\
\text { Size }\end{array}$ \\
\hline & $\mathbf{k}$ & $\Pi \mathrm{i}$ & $\%$ (e.g., 95 & bi (e.g., 5\%) & $B$ & $\mathbf{N}$ \\
\hline 2020 & & $26 \%$ & $90 \%$ & $10 \%$ & 6.238533 & 120 \\
\hline
\end{tabular}

\begin{tabular}{|c|c|c|c|c|c|c|c|c|c|}
\hline & & & & Reference & Data & & & & \\
\hline Classified Data & Shallow water & Tree & Grass & Structure & Semi wet & Bare land & Sand & water & \\
\hline - & |--------- & |-------- & --------- & |--------- & |--------- & |-------- & |------- & 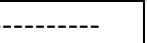 & \\
\hline Shallow water & 9 & 0 & 2 & 0 & 2 & 0 & 0 & 0 & 13 \\
\hline Tree & 0 & 13 & 1 & 0 & 1 & 0 & 0 & 2 & 17 \\
\hline Grass & 0 & 3 & 8 & 1 & 1 & 2 & 0 & 0 & 15 \\
\hline Structure & 1 & 0 & 1 & 8 & 1 & 3 & 1 & 0 & 15 \\
\hline Semi wet & 0 & 0 & 0 & 0 & 15 & 0 & 0 & 0 & 15 \\
\hline Bare land & 0 & 0 & 0 & 0 & 0 & 15 & 0 & 0 & 15 \\
\hline Sand & 0 & 0 & 0 & 0 & 0 & 0 & 15 & 0 & 15 \\
\hline Water & 0 & 0 & 0 & 0 & 0 & 0 & 0 & 15 & 15 \\
\hline Total & 10 & 16 & 12 & 9 & 20 & 20 & 16 & 17 & 120 \\
\hline
\end{tabular}


For the accuracy statement, the number of samples needed to evaluate the classification accuracy for a classification of 5 classes, $90 \%$ confidence and $10 \%$ precision was estimated. Multinomial distribution method was followed to calculate the sample size (Jensen, 2016). By using Equalized Random distribution parameters, 120 points were generated. Next, the points were interpreted for their land class and an accuracy report was generated. From the confusion matrix, it can be observed that like the predevelopment map, the land cover class 'Grass' and 'Structure' was wrongly classified in some cases, and therefore had a lower user's accuracy.

\begin{tabular}{|l|r|l|l|r|}
\hline Producer's Accuracy: & Percentage & & User's Accuracy: & Percentage \\
\hline Shallow water & $90.0 \%$ & & Shallow water & $69.2 \%$ \\
\hline Tree & $81.3 \%$ & & Tree & $76.5 \%$ \\
\hline Grass & $66.7 \%$ & & Grass & $53.3 \%$ \\
\hline Structure & $88.9 \%$ & & Structure & $53.3 \%$ \\
\hline Semi wet & $75.0 \%$ & & Semi wet & $100.0 \%$ \\
\hline Bare land & $75.0 \%$ & & Bare land & $100.0 \%$ \\
\hline Sand & $93.8 \%$ & & Sand & $100.0 \%$ \\
\hline Water & $88.2 \%$ & & Water & $100.0 \%$ \\
\hline
\end{tabular}

\begin{tabular}{|l|l|l|l|l|r|}
\hline $\mathrm{N}=$ & 120 & & Landform & Area (ha) & Percentage \\
\hline $\mathrm{d}=$ & 98 & & Shallow Water & 86.44 & $0.6 \%$ \\
\hline $\mathrm{q}=$ & 1812 & & Tree & 3084.57 & $22.7 \%$ \\
\hline & & & Grass & 2487.47 & $18.3 \%$ \\
\hline Kappa Estimation & $79.0 \%$ & & Structure & 3549.98 & $26.1 \%$ \\
\hline & & & Sami-Wet & 1280.94 & $9.4 \%$ \\
\hline & & & Bare land & 2439.44 & $17.9 \%$ \\
\hline Overall accuracy & $81.7 \%$ & & Sand & 339.07 & $2.5 \%$ \\
\hline & & & Water & 331.69 & $2.4 \%$ \\
\hline Foody 1992 statistic & $61.1 \%$ & & Total & 13599.6 & $100 \%$ \\
\hline
\end{tabular}

Table2: Accuracy Statement of pre-development landform Supervised classification

From the accuracy statement, it is observed that the classification worked well in most of land form. The kappa statistics was 79.0 which suggested that the map was not a result of random classification. The overall map accuracy was 81.7. The post-development map had a lower level of accuracy and a lower kappa value, but still performed quite well in identifying semi-wetland areas, trees and bare land. 


\subsection{Water Flow and Watershed Analysis}

Watershed is the part of the land within which water flows down through streams or canals and drains into a larger water body like river, lake or sea. Watershed edges are derived from the topography of an area. This chapter will discuss the steps of watershed analysis that were done to identify the water flow characteristics and watershed boundaries of the surrounding areas of Purbachal New Town.

For this purpose, GIS-based analysis tools were used. A geographic information system (GIS) applies geographic science with various tools to collect data and map them in a systematic way in order to create analysis and represent the spatial or geographic information of an area. GIS applications are tools that allow users to create queries regarding the topographical characteristics of an area, analyze spatial information to generate hydrological context, edit data in maps and present the results of all these operations as water flow paths and watershed boundaries. The watershed analysis offers an understanding of the watershed environment which plays an important role to guide the design decision-making process. Understanding the water flow mechanism of an area helps to identify possible locations that are suitable for future development and categorizes areas that might be susceptible to different levels of flooding. Results from the watershed analysis can be crucial to develop ecologically sustainable planning guidelines by determining environmental needs to assist ecosystem functions. Through watershed analysis of the Purbachal New Town and surrounding areas, different areas ware classified bases on their inherent watershed characteristics.

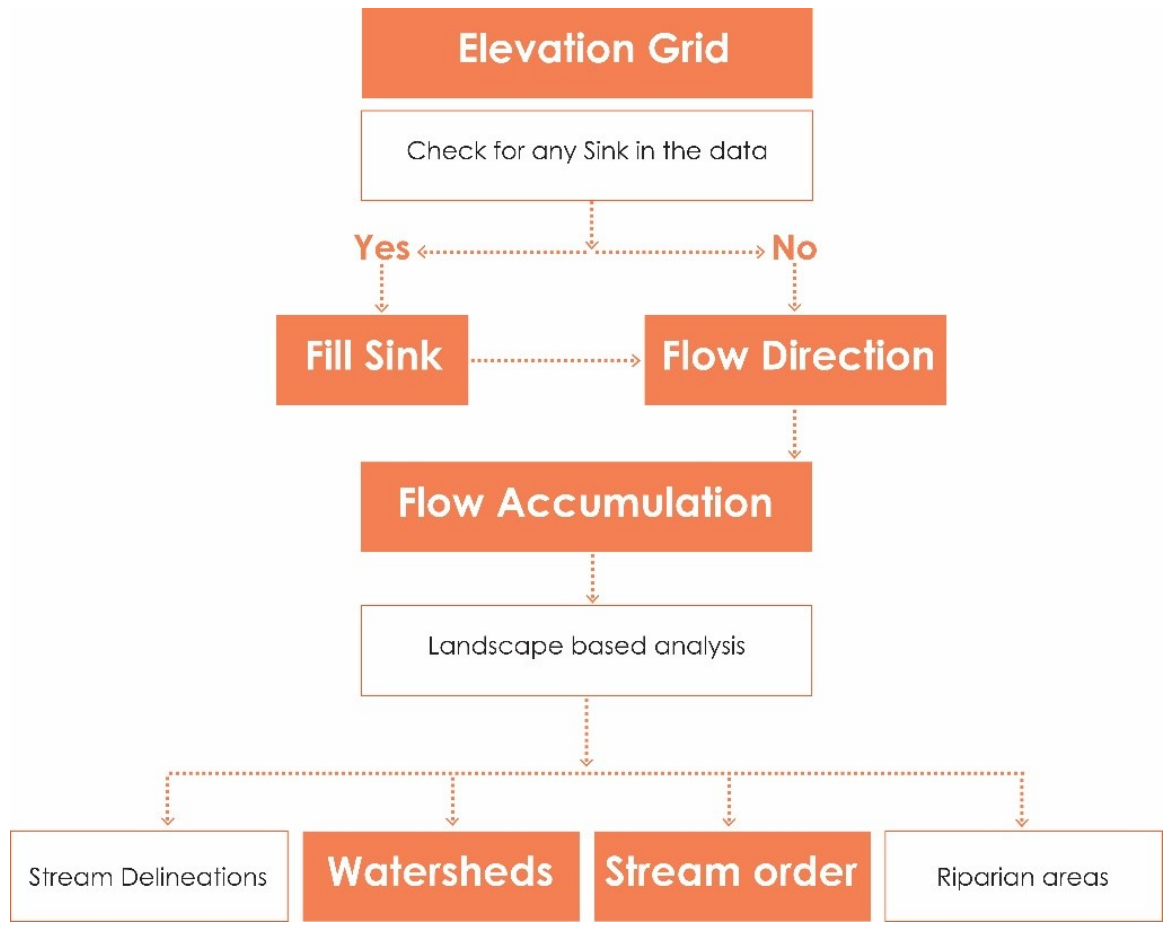

Figure 4.15: Steps of Watershed Analysis 


\subsection{Digital Elevation Model}

To understand the water flow dynamics of the area, it is important to denote watersheds by stream segments. For this purpose, Digital Elevation Model (DEM) of the study area was acquired. The Advanced Land Observing Satellite (ALOS) data from 2006-2015 was collected. It is very important to have a good elevation dataset to start the hydrological analysis. The cell size resolution and temporal properties should match the planning scale. For city-level planning, a 10-meter elevation grid is a good elevation grade cell size to use which corresponds with the 1 to 24,000 scale data.

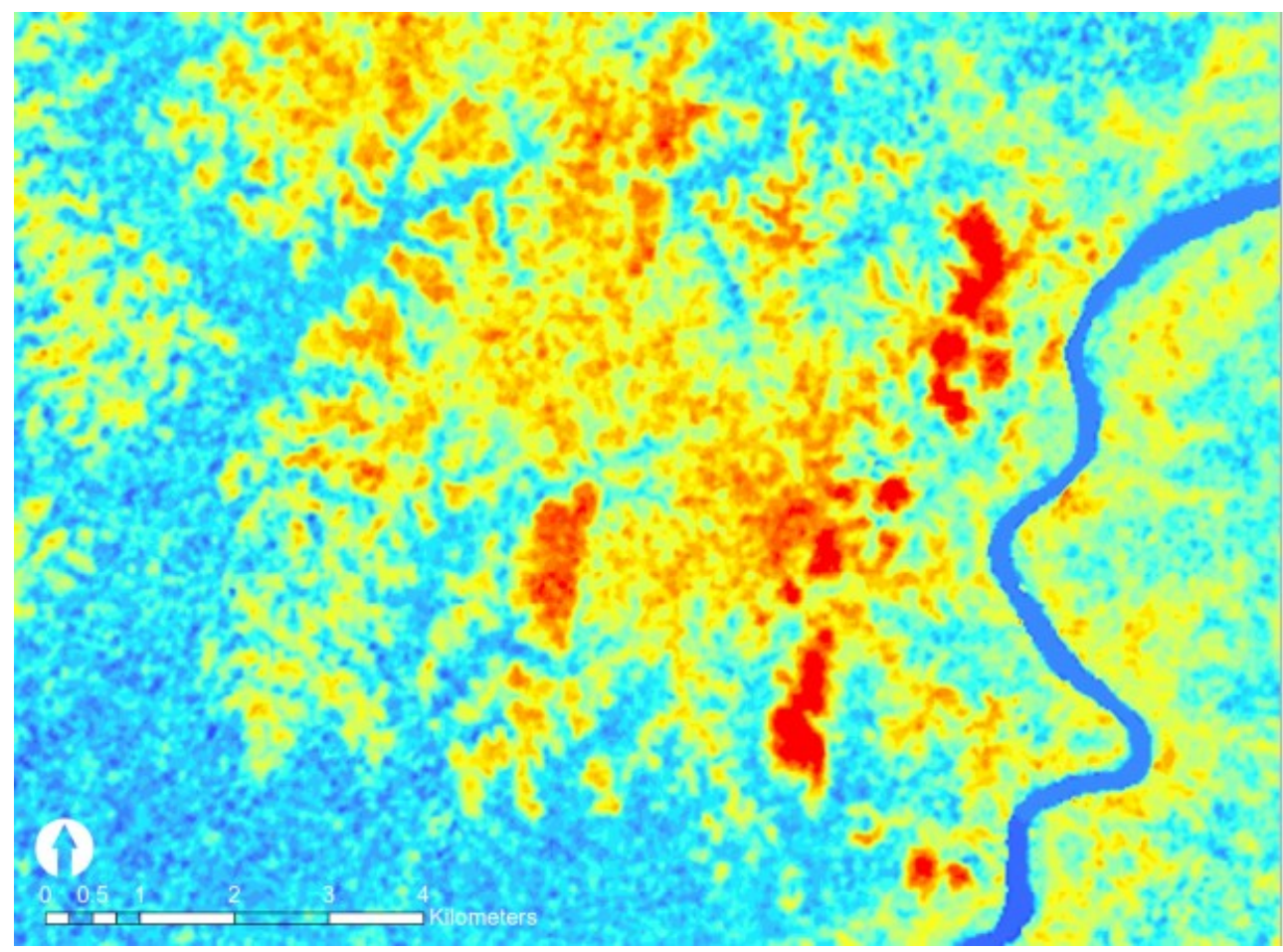

Digital elevation model- Dataset: (c) JAXA/METI ALOS PALSAR L1.0 2008. Accessed through ASF DAAC 21 February 2020

Beam Mode - FBSmore

Path $\cdot 502$ more

Frame $\cdot 460$ more

Flight Direction - ASCENDING more Polarization $\cdot \mathrm{HH}$ more

Off Nadir Angle $\cdot 34.3$

Faraday Rotation - 1.172113

Absolute Orbit +11489

Matching Frames $\cdot 18$

Data courtesy of JAXAMMETI

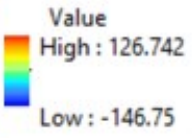

Figure 4.16: Digital elevation model of Purbachal- 2008

For analyzing the pre-development hydrological characteristics of the Purbachal New Town and surrounding areas, ALOS PALSAR DEM with spatial resolution of $12.5 \mathrm{~m}$ was collected from Alaska Satellite Facility Distributed Active Archive Center (ASF DAAC) (Dataset: (c) JAXA/METI ALOS PALSAR L1.0 2008. Accessed through ASF DAAC 21 February 2020).

The DEM data provides a better understanding of the pre-development topography of Purbachal. Most of the area is part of a larger wetland system. The main waterbody around the site is the Shitalakshya River on the east side. There are patches of Pleistocene era high land terrace which creates a landscape intertwined with water. As season changes, the area surrounding these patches of high land gets flooded creating braided chains of land. 


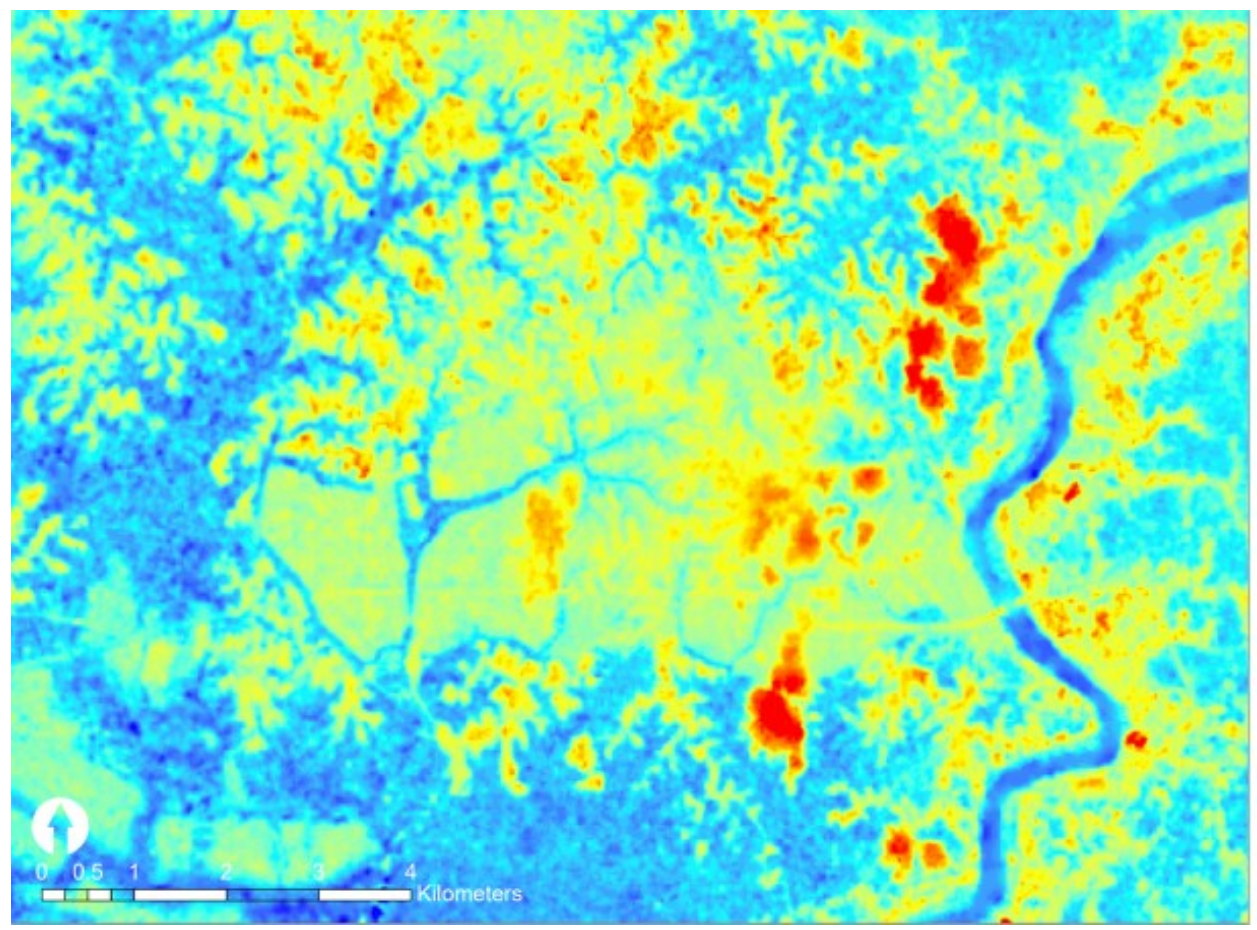

\section{Digital elevation} model- Dataset:ASF DAAC 2015, ALOS PALSAR_Radiometric_Ter rain_Corrected_low_res: Includes Material () JAXA/METI 2007.

Accessed through ASF

DAAC 21 February 2020

DOI: $10.5067 / \mathrm{JBYK} 3 \mathrm{~J} 6 \mathrm{HF}$

SVF

Figure 4.17: Digital elevation model of Purbachal- 2015

To compare the modified hydrology of the area with pre-development scenario, ALOS PALSAR DEM with spatial resolution of $30 \mathrm{~m}$ was collected from JAXA Global ALOS portal (Dataset: ASF DAAC 2015, ALOS PALSAR Radiometric Terrain Corrected low res; Includes Material (c) JAXA/METI 2007. Accessed through ASF DAAC 21 February 2020.DOI: 10.5067/JBYK3 J6HFSVF). The spatial resolution was converted to $12.5 \mathrm{~m}$, so it is easily comparable with the predevelopment conditions.

\subsection{Fill DEM}

The raw DEM needs to be processed before caring out hydrological analysis. Each cell is part of a three by three grid network and for flow direction analysis, the elevation of surrounding cells needs to be considered. In the DEM, there might be cells where all surrounding cells from a cell have higher elevation values. This is called a sink, in this situation, the water will pour out from the pour point on the boundary cell for the contributing area of a sink when the sink is filled.

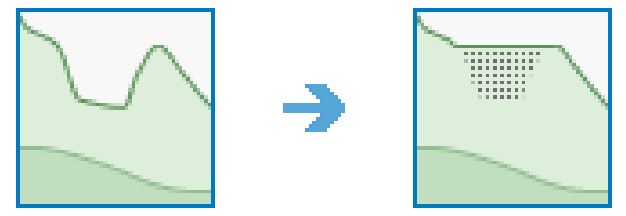

Figure 4.18: Concept of Fill sinks (source: https://pro.arcgis.com) 
To fix the DEM and correct these issues and problems with overland flow across the landscape, Fill DEM command is used. Fill DEM is a basic hydro command for processing an elevation surface which eliminates sinks or depressions in the DEM where water can get trapped.

The fill command raises the lowest cell of the sink to the highest one adjacent to it. The one lowest cell in the center goes to the next highest elevation point of the eight different cells around it. In a relatively flat landscape like Bangladesh, water does not always flow, rather it can sit around to create natural open water wetland or forested wetland. The fill command assumes these still water bodies out of the equation to get overland flow across the landscape.

\subsection{Flow Direction}

After converting the elevation data, the filled DEM raster is generated. The filled DEM becomes the input for the Flow Direction. This process creates a raster of flow direction from each cell to its downslope neighboring cells. The values for each direction from the center are the following:

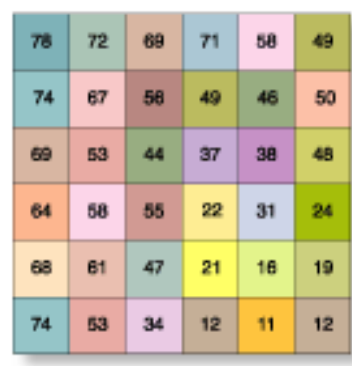

Elev_Ras

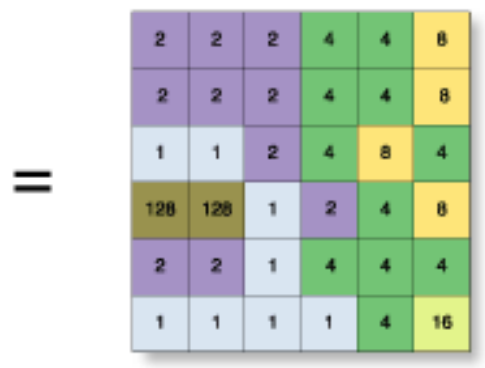

Flow_Dir

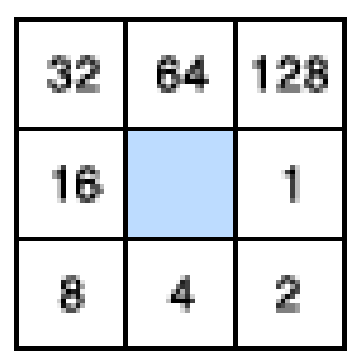

Figure 4.19: Concept of Flow Direction (source: https://pro.arcgis.com)

The eight cardinal directions are represented by eight numbers. So, for example, if water flows from a cell to south direction, the flow direction would be coded as 64. For the southeast direction, it gets a value of 2 if it goes to the north and west Direction it's a value of 32 and so on.

According to Qin et al. (2007), The Multiple Flow Direction (MFD) algorithm, partitions flow from a cell to all downslope neighboring cells. A flow-partition exponent is derived from an adaptive approach based on local topography conditions. This method is used to determine the fraction of flow draining to all downslope neighbors. By choosing to 'force all edge cells to flow outward' in the flow direction command, it was assured that the process is creating a path from every cell to another cell. So, all cells at the edge of the surface raster will flow outward from that surface raster.

The flow direction grid created from the filled elevation surface provides One Directional values which are assigned based upon the path that water would likely to take based upon the elevation values in eight different directions from that cell. 


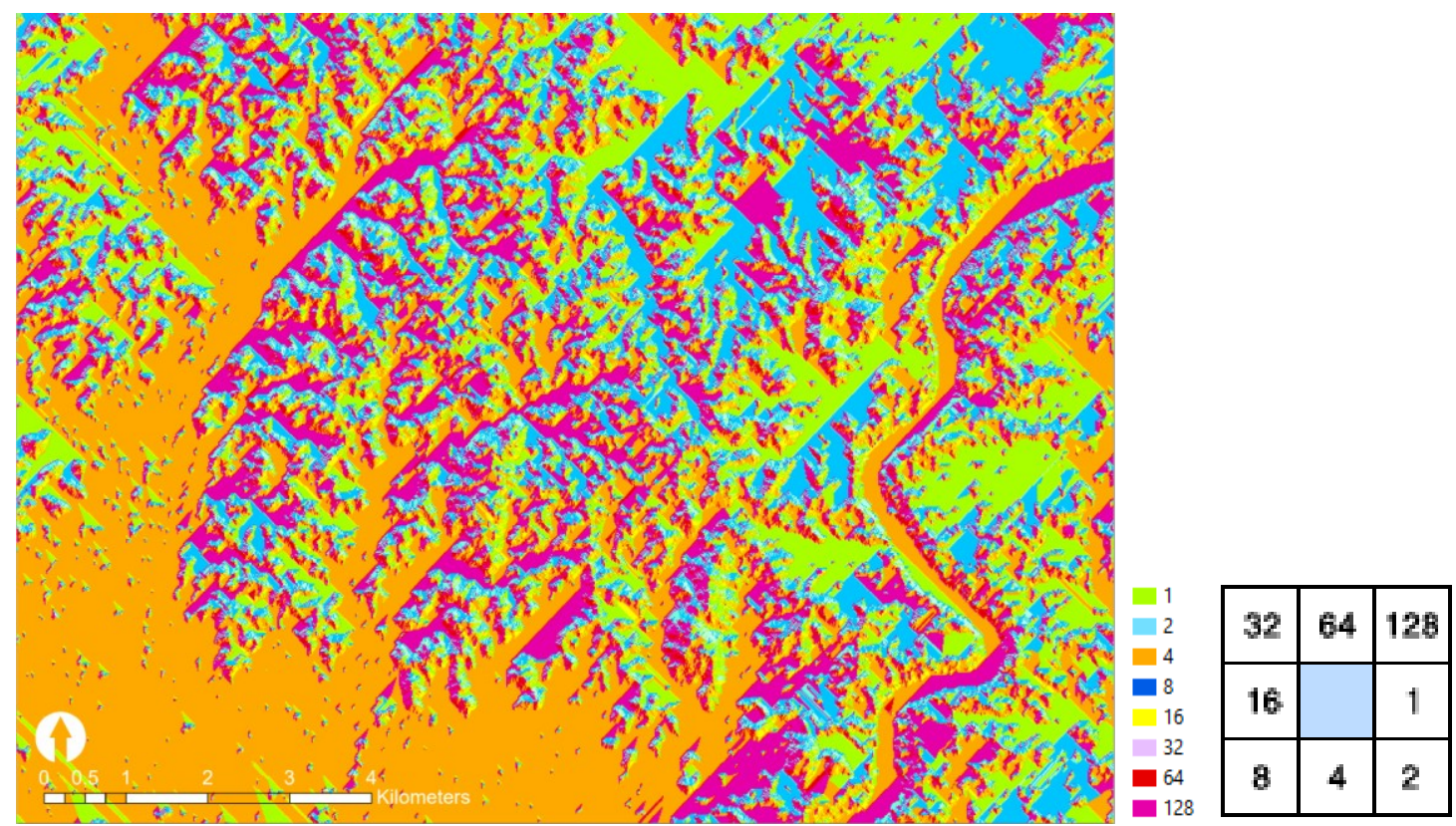

Figure 4.20: Pre-development flow direction map of Purbachal and surrounding areas

By analyzing the pre-development flow direction map, the western part of the site has a large area where water is flowing towards south. The water flows from the patches of relatively higher ground to the adjacent river on the east or towards the wetland on the west and the general flow direction is towards the south.

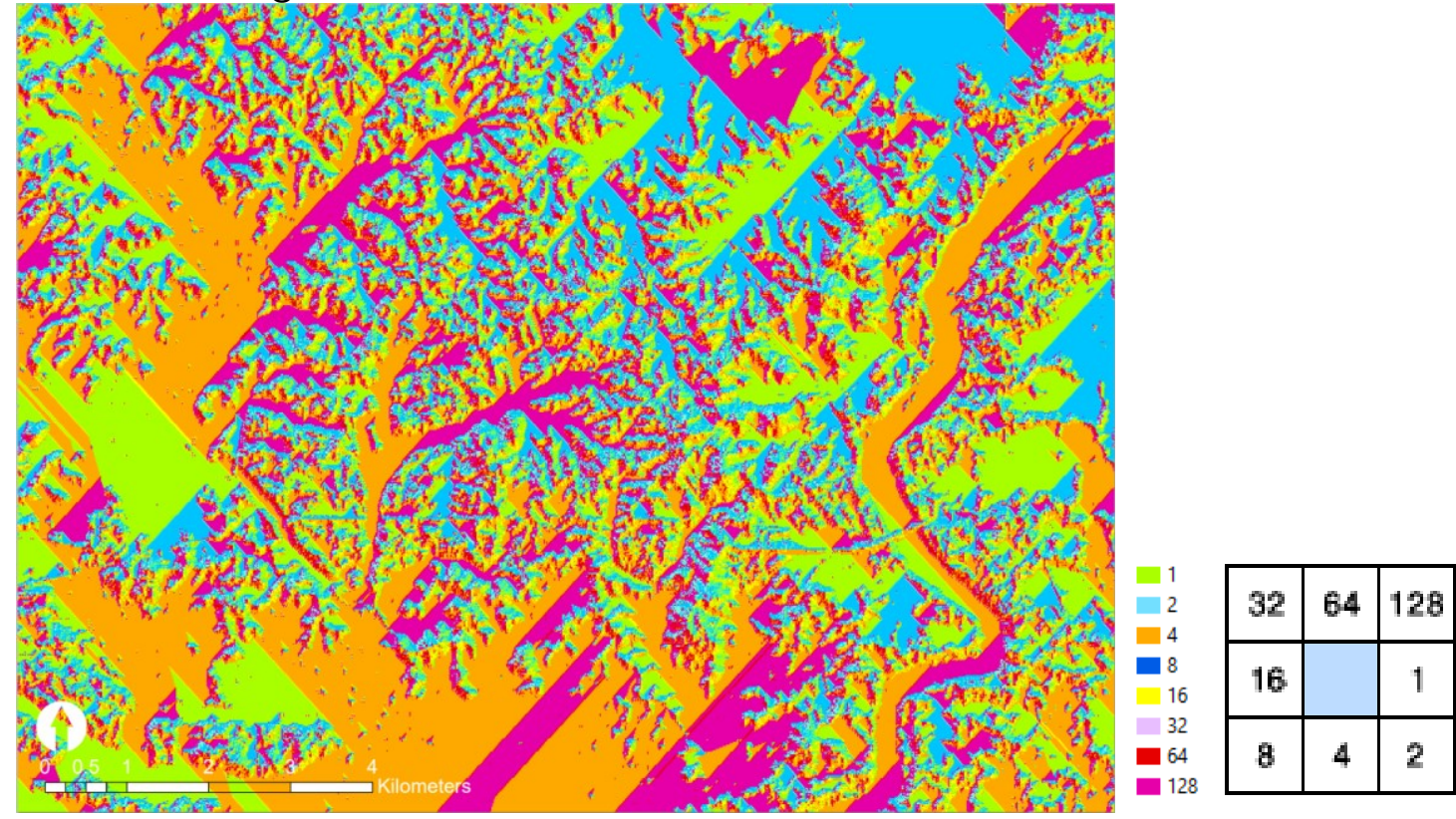

Figure 4.21: Post-development flow direction map of Purbachal and surrounding areas

In contrast, the post-development flow direction map clearly shows the drastic change in water flow pattern. The area on the western side of the site has been filled up which is interrupting the natural flow direction. As a result of this, water is diverted into different directions causing flood risk for new developed areas as well as existing eastern part of Dhaka city. 


\subsection{Flow Accumulation}

Flow Accumulation creates a raster of accumulated flow into each cell by using a flow Direction grid as an input. The flow accumulation is based upon the number of cells that flow from one site to another. This process calculates or tallies up the number of cells from the flow direction grid.

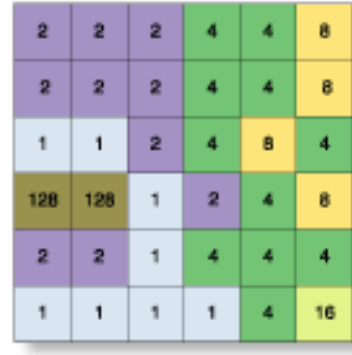

Flow_Dir

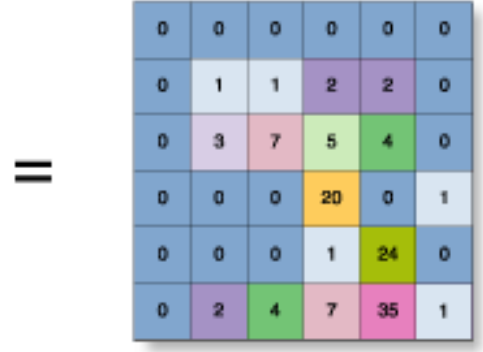

Flow_Acc

Figure 4.22: Concept of Flow Accumulation (source: https://pro.arcgis.com)

By accumulating the number of total or a portion of cells that flows into each cell in the output raster, the accumulated flow is developed. If the cell is on a ridgeline, a value of zero will be assigned to that cell because there are no cells that flow to this cell. The higher value on a cell suggests that there is a lot of cells above that cell from which water is flowing to this higher value cell. The output cells where the flow is concentrated have a high flow accumulation which can be used to identify water streams. This essentially creates a drainage network which is topography driven as it counts the number of cells that flow to a location.

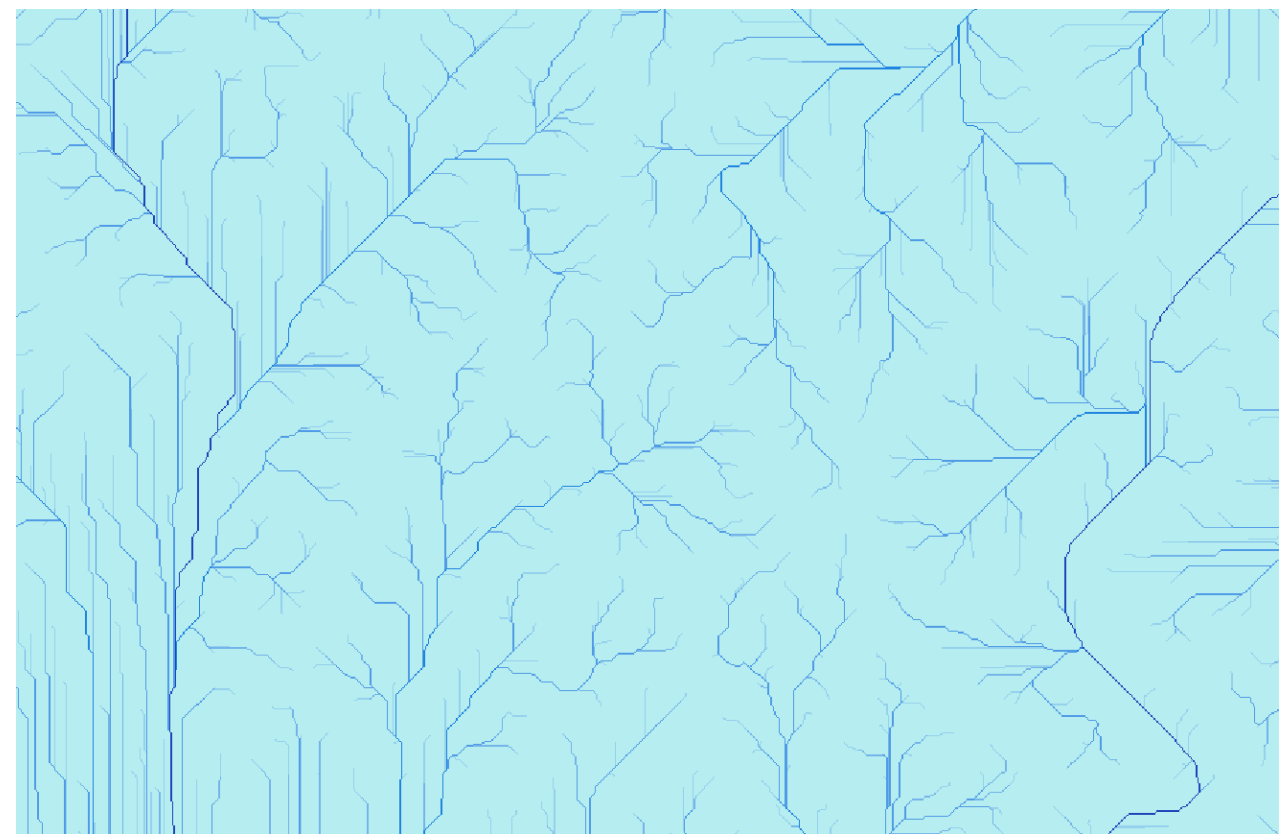

$\square 0-250$

$\square 250.0000001-500$

$\square 500.0000001-1,000$

$\square 1,000.000001-10,000$

- 10,000.00001 - 100,000

- 100,000.0001 - 500,000

- $500,000.0001-2,500,000$

- 2,500,000.001- 5,000,000

- 5,000,000.001-13,406,847

Figure 4.23: Pre-development flow accumulation map of Purbachal New Town and surrounding areas 
The output map was changed to Natural breaks. The darker color represents more flow accumulation. This can identify small tributary flowing to another location as compared to the main stem which has higher flow accumulation cells.

From the flow accumulation grid, we can query individual cells and those pixel values as well. The stretched value that corresponding here is related to the number of cells that flow to that location.

So, if there are 1,000 cells that flow to a location and each cell is $12.5 \mathrm{~m}$ by $12.5 \mathrm{~m}$ in size $(156.25 \mathrm{~m} 2)$, then the total drainage area is $(1,000) *(156.25)=156,250 \mathrm{~m} 2$

Or

$\left(156,250 \mathrm{~m}^{2} \times 0.0001\right)=15.625$ hectares $(38.6$ acres $)$

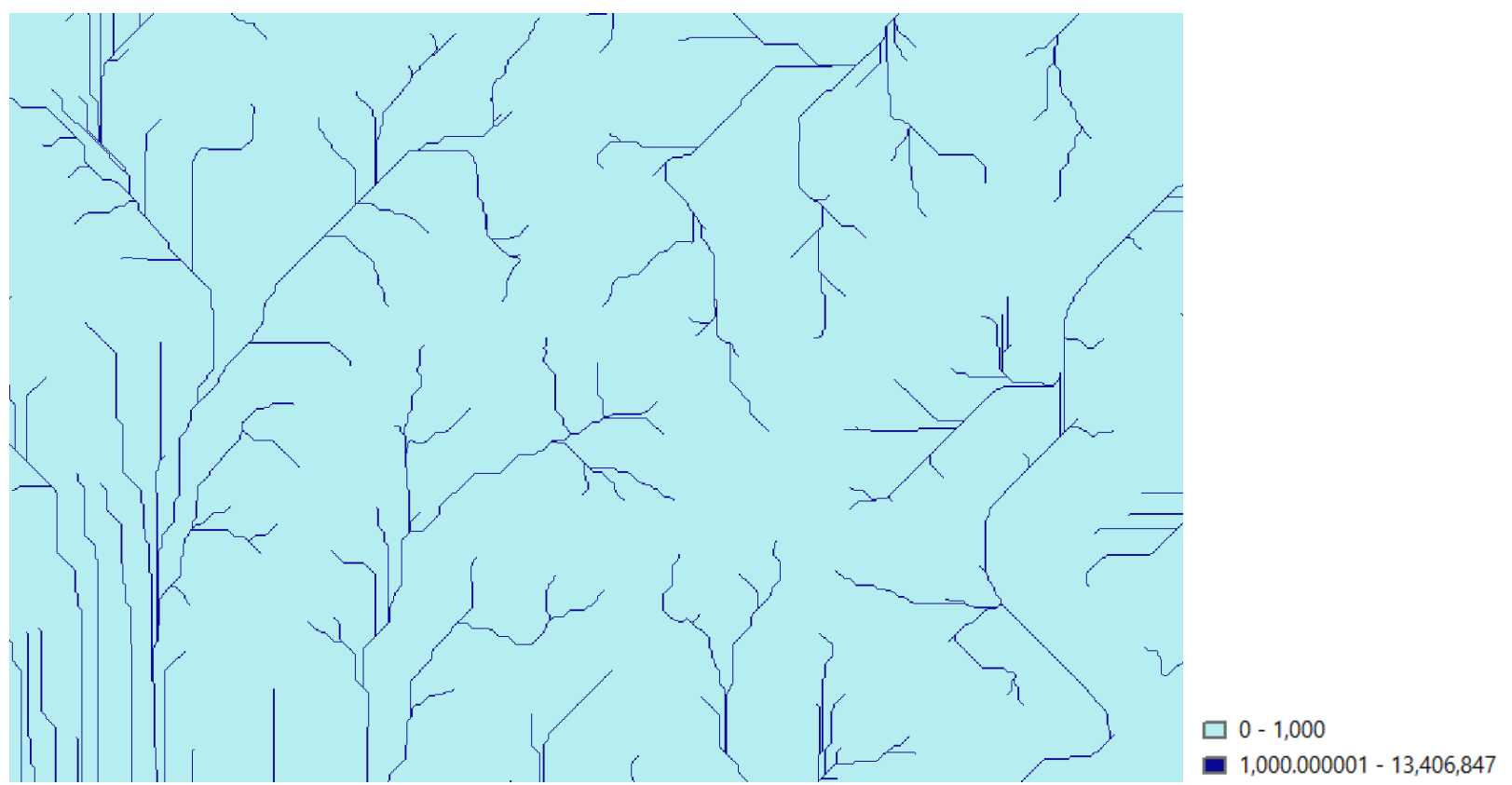

Figure 4.24: Modified Flow accumulation map of Purbachal New Town and surrounding areas

Therefore, if a cell value is above 1000, it is working as a drainage point for around 40 acres of land. By changing the legend properties again from 9 classes to 2, and based upon that breakpoint value of 1000, the locations that drain at least 1000 flow accumulation units or more are identified. By this process, all the major flow networks are highlighted.

From this output grid, stream grid dataset was created which consist of all the stream network that drain areas at least 40 acres in size. Then the thin command was used to thin the streams. Using this thin stream layer as the bottom of the drainage pattern and using all the elevation values above the overland flow across the landscape is generated. 


\subsection{Burn DEM}

To correct surface drainage patterns derived from digital elevation models (DEM) Stream Burning is used as a flow enforcement technique. The 'Burn DEM' process assures that the output elevation raster consists of all major stream patterns of the thin grid as the lowest elevation of cells around them. From the 'Thin Stream' raster, a Water Grid raster file is generated. By using the Fill DEM raster as input, a new raster (DEM +100) was created which has a hundred meters added to it. The focal statistics command was used to calculate the focal Min. Then the water grid and focal minimum values were used to generate stream elevation.

Using 'Is null' command, a 'No data' stream cell was created. This was multiplied with the DEM +100. The 'No data' output, stream elevation and DEM +100 are used to complete the burn process. The burn process shows the deepest area for the stream.

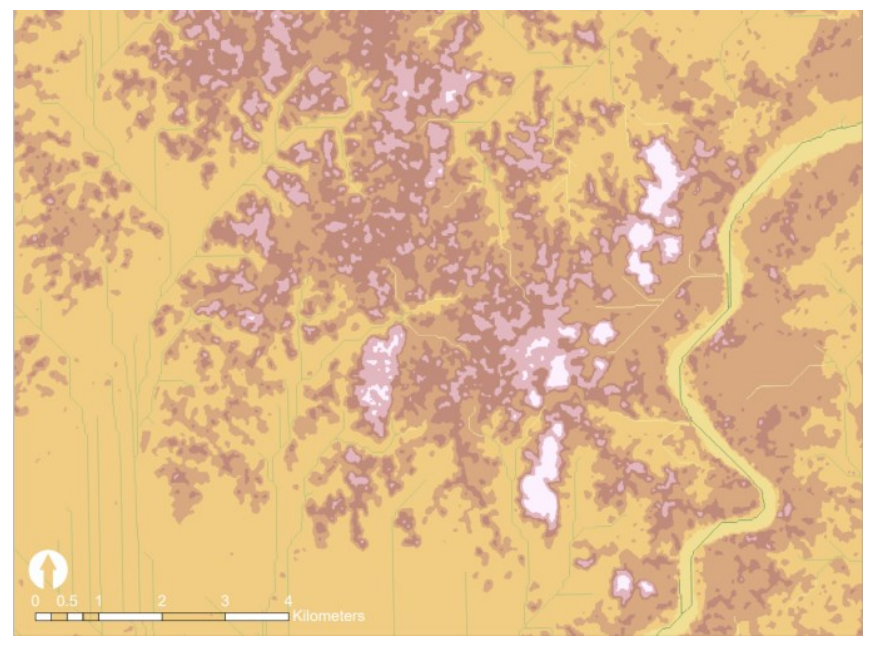

Figure 4.25: Output of Burn DEM- 2006

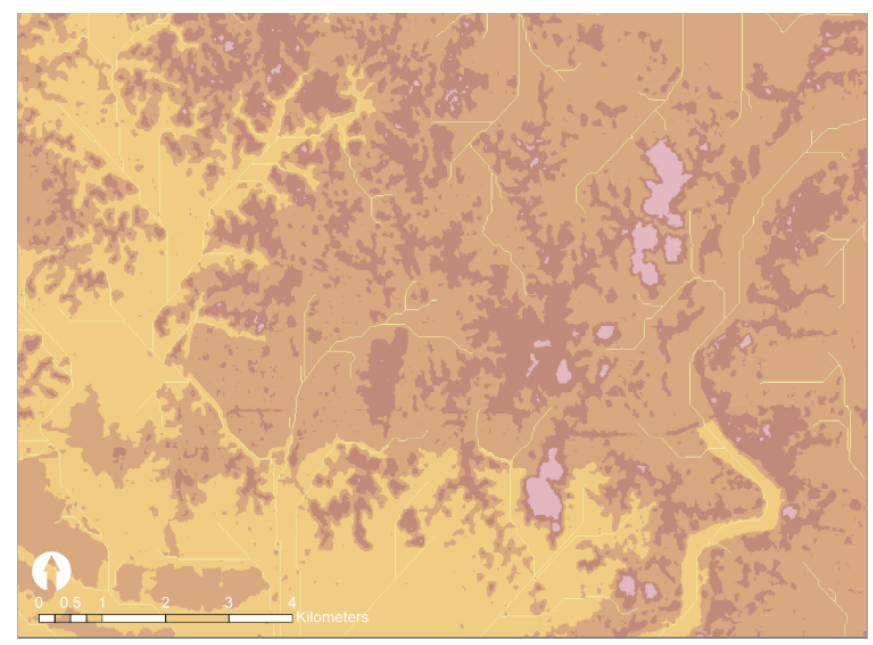

Figure 4.26: Output of Burn DEM- 2015

The Burn DEM has the actual stream values and everything outside of it has an elevation plus 100 creating a trench or "burn-in" effect. This is a relative grid that will be used in later phases.

This process adjusts the elevations of grid cells that are coincident with the features of a vector hydrography layer. Therefore, by using the Burn DEM as input will generate a more accurate hydrological analysis. Using Burn DEM as the first input, Fill DEM. Flow Direction, Flow Accumulation, and Water Grid raster sets are again generated. 


\subsection{Watershed Map}

Developing the delineated watershed is the final step of the watershed analysis. There are three main procedures to create the watershed. These are-

- Targeted areas in a stream as pour points

- Watersheds by stream segment and

- Off-stream delineation

For this study, Watersheds by stream segment method was used. This method uses a stream network to generate corresponding watershed boundaries. The number and size of watersheds depend on the density of the stream network. For example, a denser stream network will result in many small watershed boundaries.
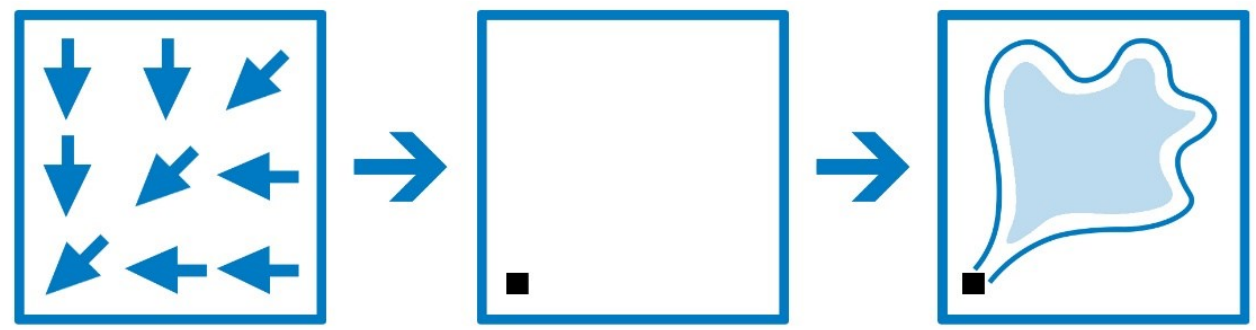

Figure 4.27: Watershed boundary (source: https://pro.arcgis.com)

The first step is to create a stream link grid that gives a unique identifier to each stream segment where a segment is defined as the water flow on a single line between junctions. The Stream Link command creates a one to one relationship between each stream segment a catchment with it. This assigns unique values to each of the raster sections.
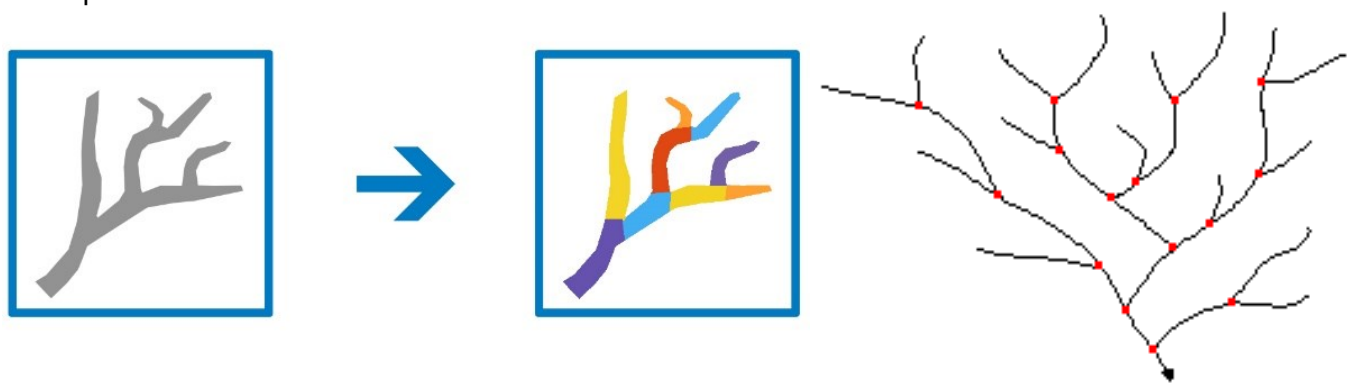

- Links
- Junctions

Figure 4.28: The raster representation of the stream network (source: https://pro.arcgis.com)

Next, the flow direction raster is used as the input for the Watershed command. From the one to one relationship between the stream segments, Watershed boundaries were identified. The result of this analysis is watersheds that correspond with each of the stream segments.

By moving the segment Watersheds below the stream link grid and changing their display properties to the unique categorical legend, pre and post development watershed boundaries of Purbachal New Town was generated. 


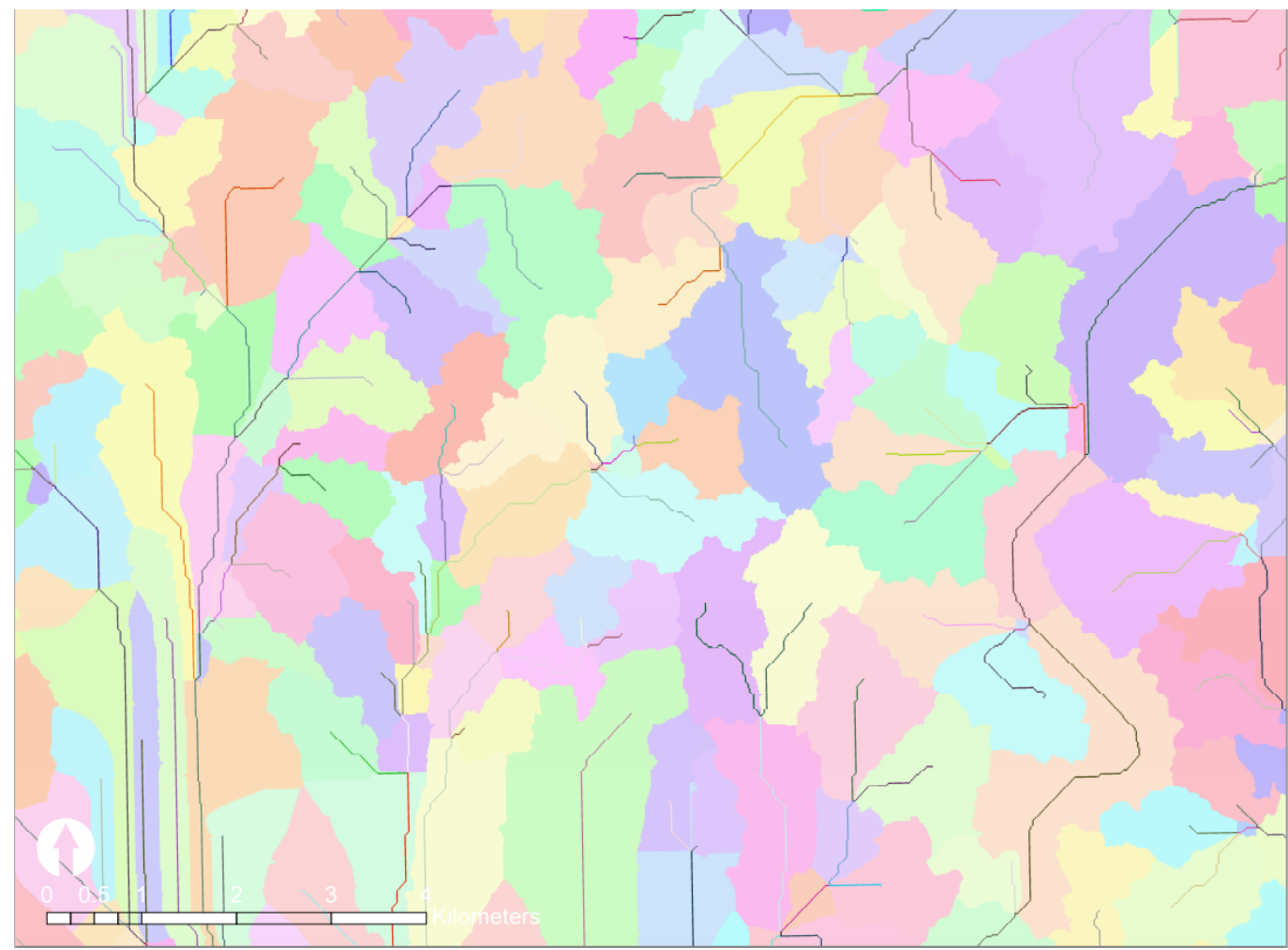

Figure 4.29: Pre-development Watershed map of Purbachal New Town and surrounding areas- 2006

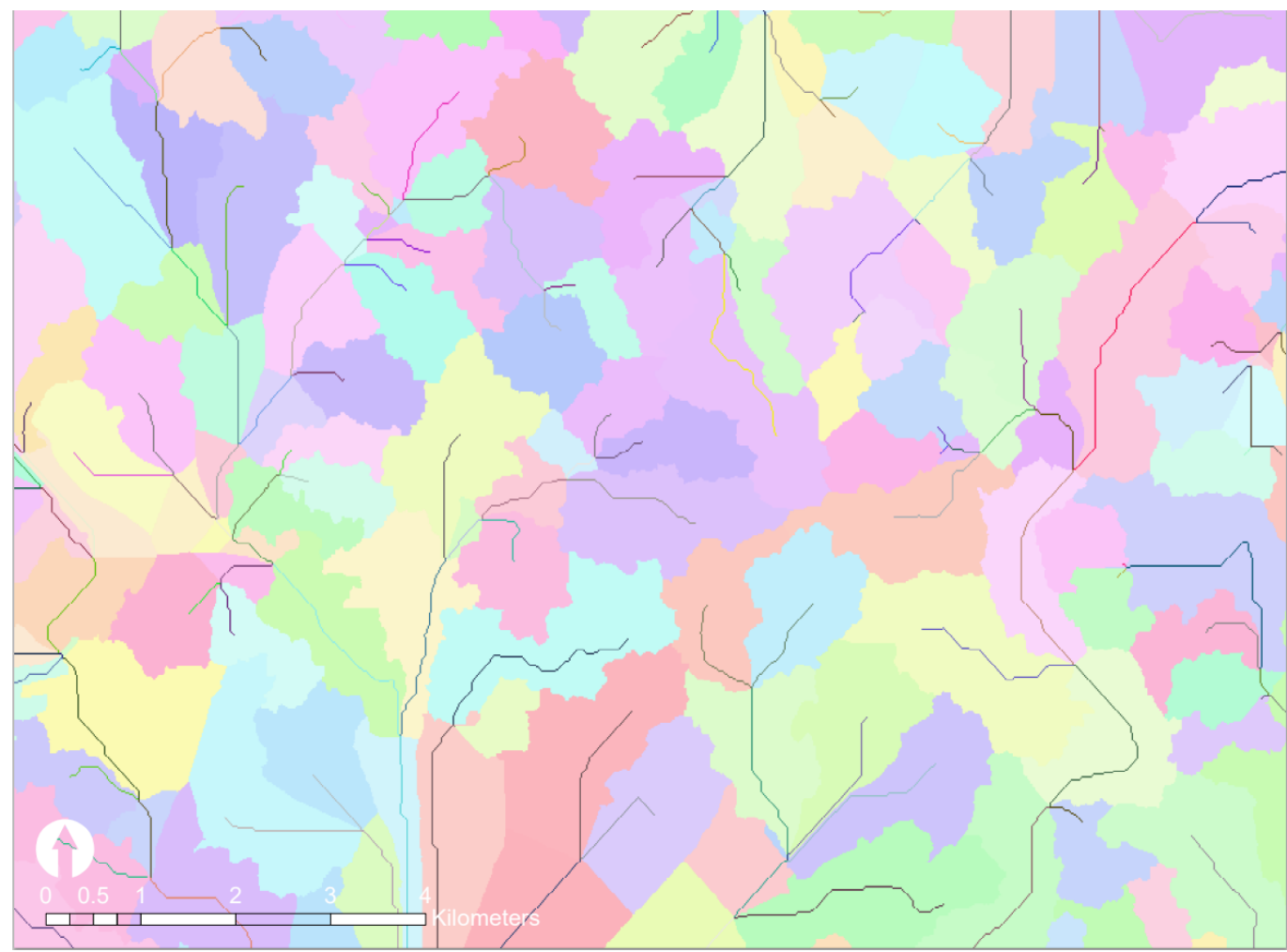

Figure 4.30: Post-development Watershed map of Purbachal New Town and surrounding areas- 2015 


\subsection{Results}

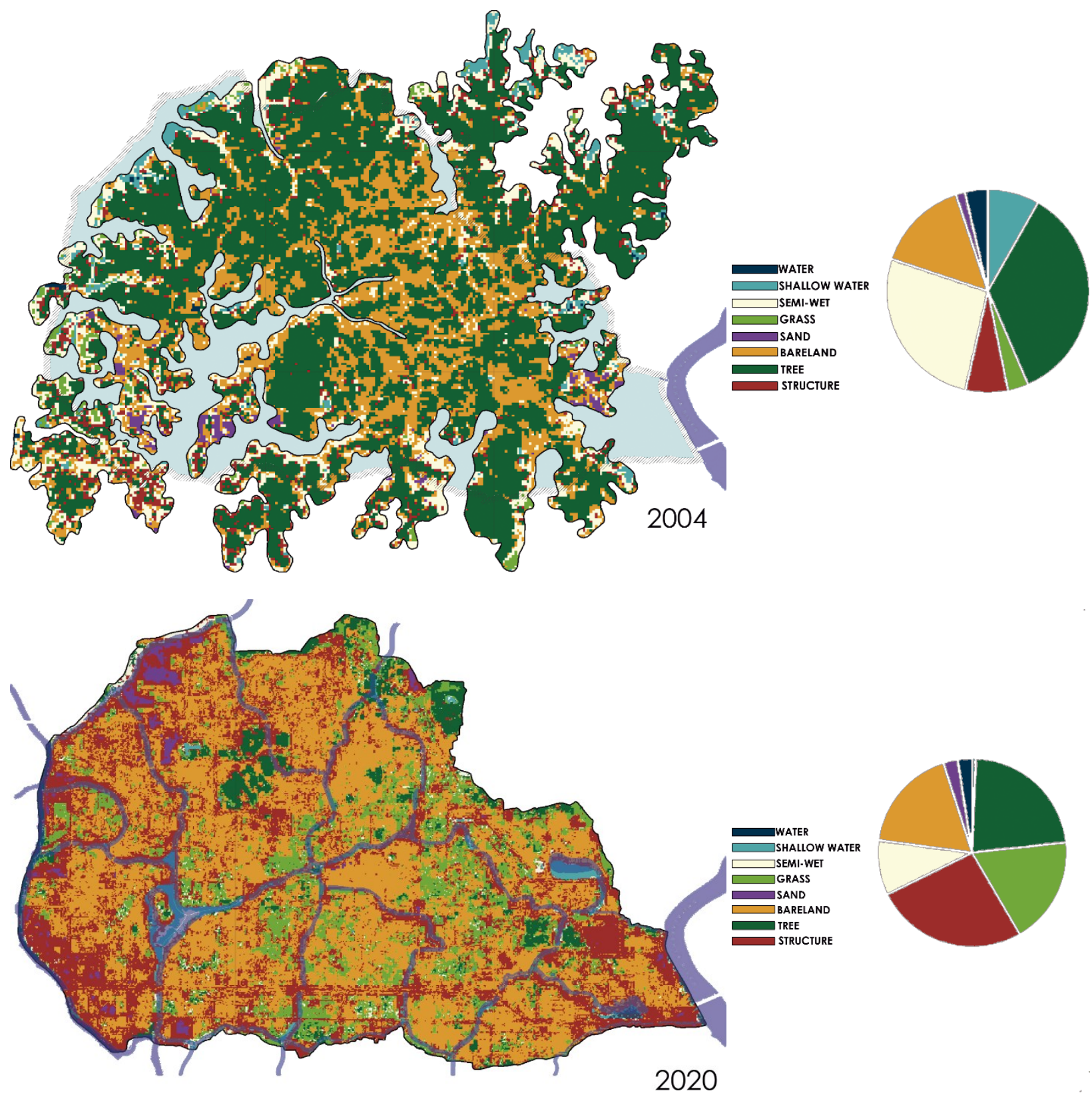

Figure 4.31: Comparison between Pre and Post-development landcover map of Purbachal New Town

By analyzing the watershed boundaries of Purbachal New Town, a major change in the watershed can be observed. Due to filling up low lands, the post-development flow direction map clearly shows the drastic change in the water flow pattern. The area on the western side of the site has been filled up which interrupted the natural flow direction. This can create flood risk for newly developed areas as well as the existing eastern part of Dhaka city 


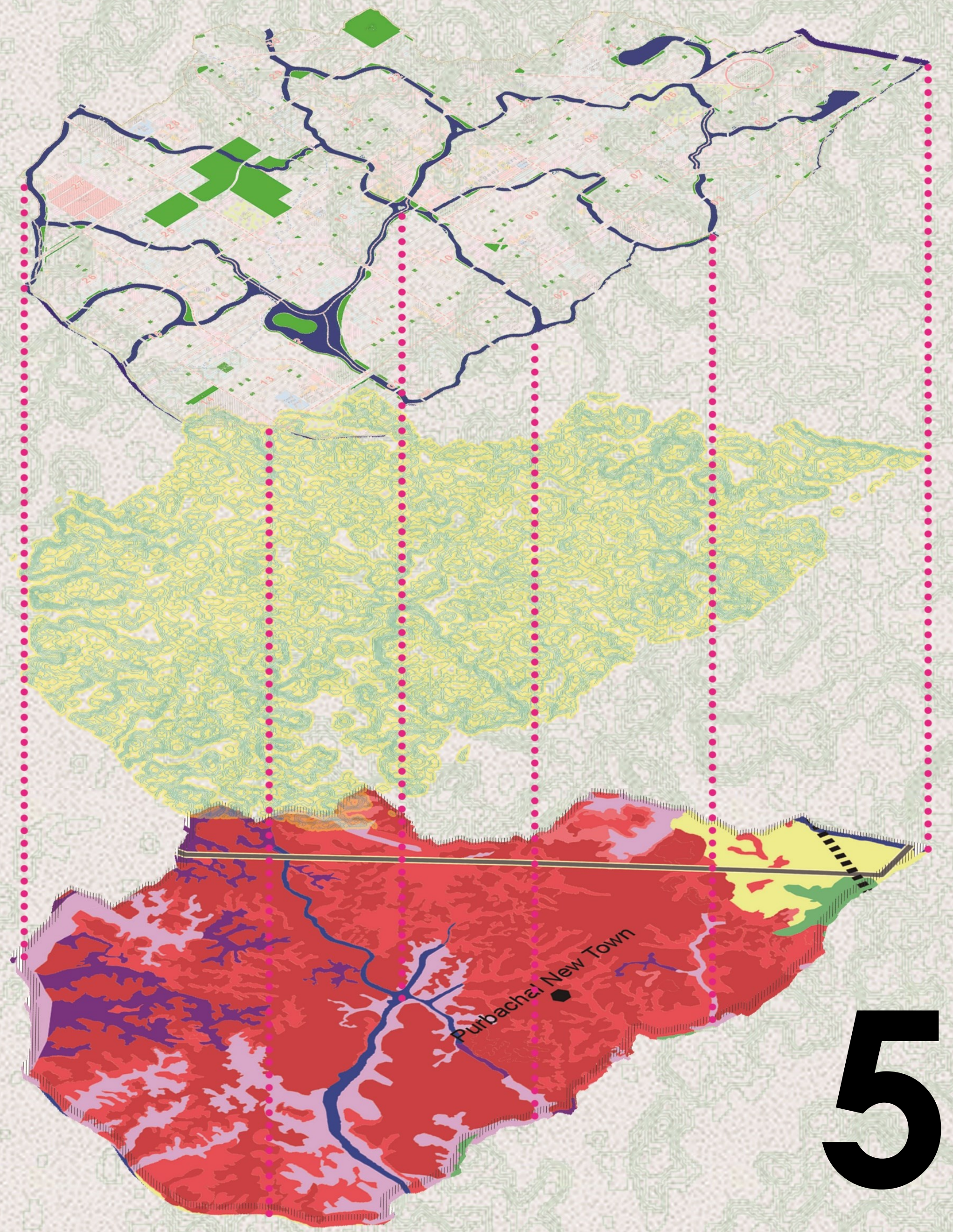




\section{Chapter 5 Evaluation of Existing Masterplan}

\subsection{Objective of the Existing Masterplan}

The tremendous pressure for accommodating the ever-increasing population of Dhaka, it was necessary to establish new satellite towns. Dhaka metropolitan development plan (DMDP) adapted policies to establish a series of new towns in the surrounding areas of Dhaka. Six major regions, each with an existing or potentially dominant urban place as its center was proposed. Purbachal is one of the proposed Regional Centre. The main objectives of the new development are:

- To reduce the pressure of the population in Dhaka city by creating opportunities to accommodate the city dwellers in the vicinity of the city.

- To create environment-friendly and sustainable strategies to balance urbanization and environmental protection.

- To reduce the existing acute problem of housing and mitigate future housing demand.

- To expand civic facilities by urbanization to the nearby and surrounding areas gradually.

- Development of new township and to expand economic facilities.

\subsection{Major Components of Land Use Plan}

- Residential Plots - $38.7 \%$

- Road network-25.8\%

- Physical \& social infrastructure $-3.1 \%$

- Lake- $7.2 \%$

- Administrative and commercial plots $-6.0 \%$

- Education \& institution $-5.7 \%$

- Forest and Eco-park -2.8\%

- Urban green-3.8\%

The main design objective for developing the satellite city was to create an environmentfriendly and sustainable plan that balanced urbanization and environmental ecology/sustainability. But the existing land-use plan ignored this by prioritizing and maximizing the land use for residential and commercial purposes. Only $2.8 \%$ of the land use were designated to forests and eco-parks, and only $3.8 \%$ of land as Urban green. The plan also ignored the expansion of civic facilities since only $3.1 \%$ of the land were designated for physical and social infrastructures. The land-use plan also ignored the inherent connection between the land and water by allocating only $7.2 \%$ of the total areas as designated waterbodies, which consist of mainly manmade canals rather than natural waterbodies. 


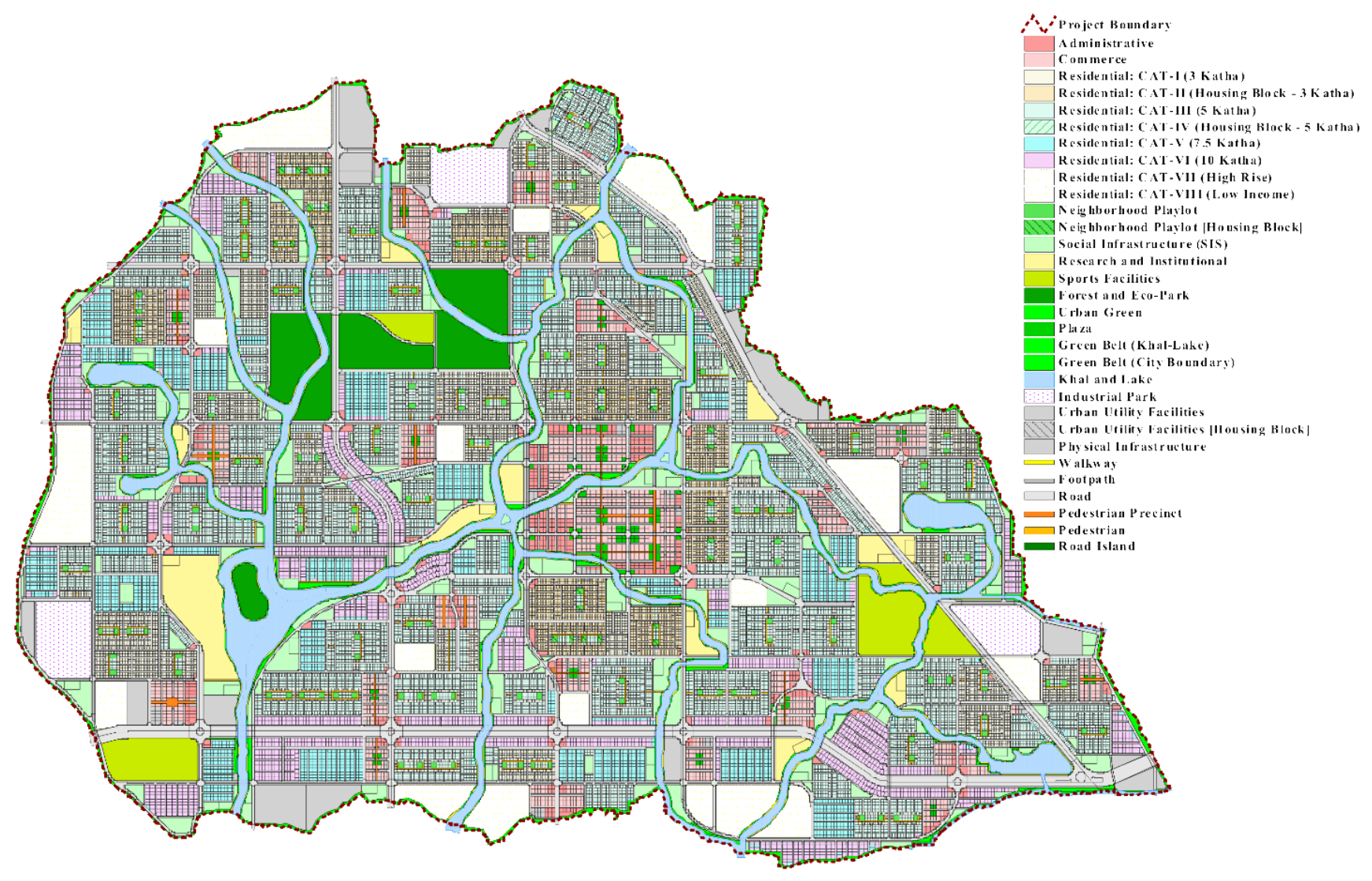

Figure 5.1: Landuse plan of Purbachal, 2012 (Source: www.rajuk.gov.bd)

The Purbachal new town land-use plan also failed to meet the per-capita open space requirements. The World Health Organization (WHO) recommends $9 \mathrm{~m}^{2}$ of open space per person. In Purbachal, the amount of open space per person is $2.3 \mathrm{~m}^{2}$. The other main cities in Bangladesh lags far behind the required amount (marked by the red circle in table 3). It may seem that the Purbachal new town land-use plan is an improvement on the existing conditions, but it is not enough to ensure a sustainable and healthy living condition.

Further analysis of the land-use plan points out other important aspects related to the planning decisions. Although the amount of open space provided in the masterplan is more than other major cities in Bangladesh, the open spaces are not provided evenly throughout the land-use plan. Most of the open spaces are clustered in one block and only a small amount of open spaces is provided within the residential blocks (Figure 5.2) in the form of play fiends. This approach of planning resulted in a potential concrete jungle detached from any connection with natural elements. The lakes and waterbodies are also not designed to be on the property frontage. Therefore, risks remain that the lakes in the future will become a backside feature due to the lack of proper maintenance as it happened before in other the waterbodies in Dhaka. 


\begin{tabular}{|c|c|c|c|c|c|c|}
\hline & City and Country & $\begin{array}{l}\text { Total Population } \\
\text { (Million) }\end{array}$ & $\begin{array}{l}\text { Urban Population } \\
\text { (Million) }\end{array}$ & $\begin{array}{l}\text { City Area } \\
\text { (Sq. Km) }\end{array}$ & $\begin{array}{l}\text { Density/ } \\
\text { Sq. Km }\end{array}$ & $\begin{array}{l}\text { Open Space/ } \\
\text { Capita }\left(\mathrm{m}^{2}\right)\end{array}$ \\
\hline \multirow{2}{*}{ Europe } & Istanbul, Turkey & 15.02 & $14.79^{1}$ & $1539^{1}$ & $2813^{1}$ & $6.4^{2}$ \\
\hline & Barcelona, Spain & 5.47 & $1.6^{3}$ & $101.9^{3}$ & $16,000^{3}$ & $5.6^{4}$ \\
\hline \multirow{3}{*}{ America } & Colima, Mexico & 7.11 & $1.7^{5}$ & $5627^{5}$ & $130^{5}$ & $6.2^{4}$ \\
\hline & Mexico City & 20.9 & $8.91^{6}$ & $1485^{6}$ & $6000^{6}$ & $3.5^{4}$ \\
\hline & Buenos Aires & 13.59 & $2.89^{7}$ & $203^{7}$ & $14,237^{7}$ & $1.90^{2}$ \\
\hline \multirow{5}{*}{ Asia } & Tokyo & 38.30 & $13.61^{8}$ & $2188^{8}$ & $6224^{8}$ & $3.00^{2}$ \\
\hline & Kuala Lumpur & 7.2 & $1.79^{9}$ & $243^{9}$ & $6890^{9}$ & $6.5^{10}$ \\
\hline & Mumbai & 20.74 & $12.3^{11}$ & $603^{11}$ & $21,000^{11}$ & $1.1^{12}$ \\
\hline & Shanghai & $24.1^{13}$ & $22.2^{13}$ & $4000^{14}$ & $3800^{13}$ & $6.1^{15}$ \\
\hline & Hong Kong & - & $7.40^{16}$ & $2754^{16}$ & $6777^{16}$ & \\
\hline \multirow{2}{*}{ Bangladesh } & Dhaka & 18.89 & 14.39 & 306.38 & 28.410 & $0.16^{18}$ \\
\hline & Chittagong & 5.2 & 4.1 & 168.1 & 14,200 & 0.18 \\
\hline
\end{tabular}

Table3: Open space in cities below the WHO recommended standards (Source: Jafrin et al. 2018)

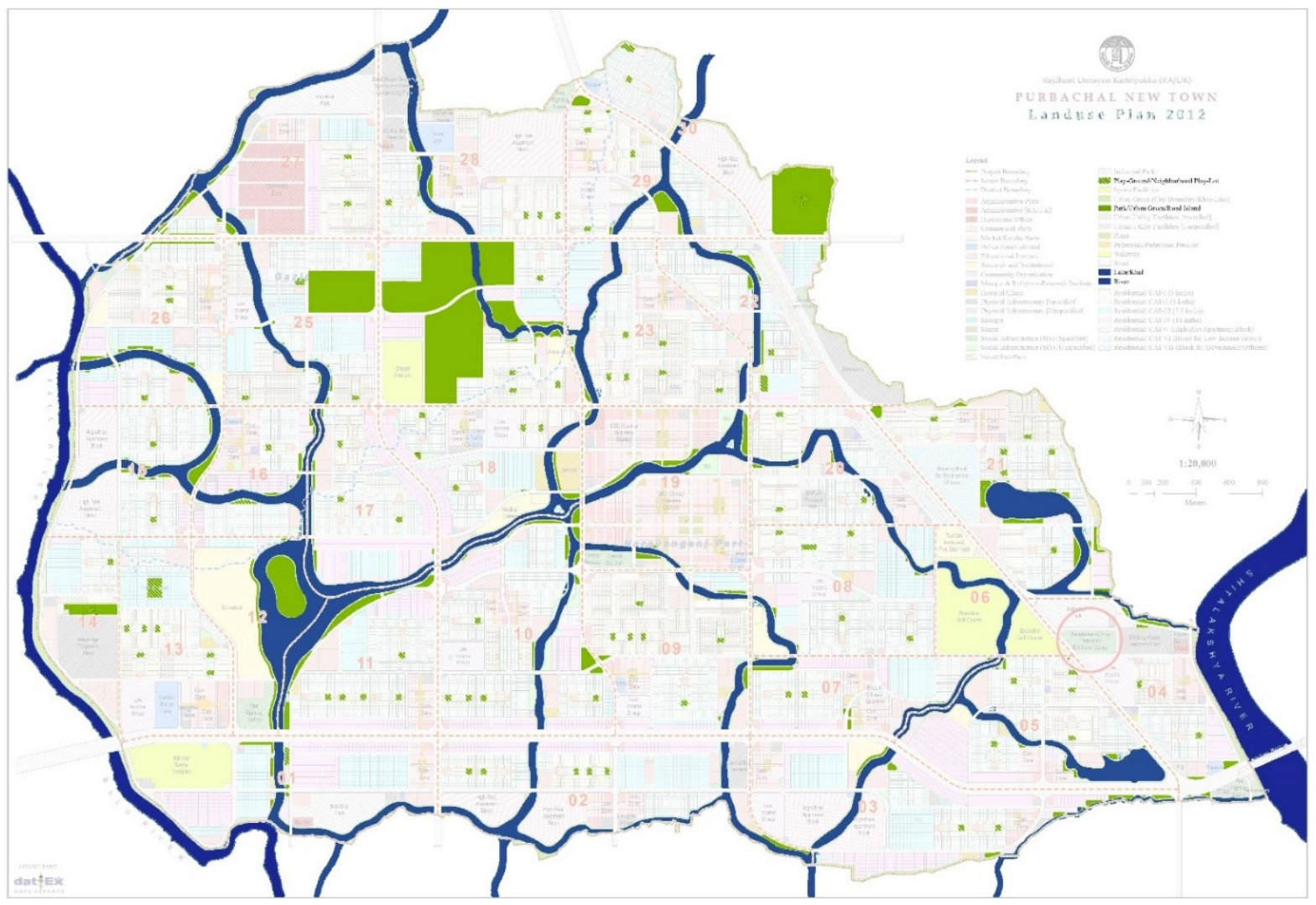

Figure 5.2: Location of open space and waterbodies in the landuse plan of Purbachal, 2012 (Source: www.rajuk.gov.bd)

To assess the performance of these water bodies, it will be necessary to perform water flow and watershed analysis to check whether the water bodies followed the natural drainage pattern of the area. As most of the proposed waterbodies are manmade, these waterbodies must follow the natural drainage pattern of the area or provisions have been taken to ensure the natural flow is not interrupted. 


\subsection{Site History and Transformation}

The development plan of the Purbachal New Town started during started during the mid90's. Even till the late 90's the surrounding areas were mainly flood plains mostly occupied by agricultural lands, small brick factories and semi-rural settlements. Most of the area was part of main flood flow area for the Dhaka city and acted as a water retention area during the heavy monsoon season. The landscapes are characterized by patches of high Madhupur Terrace land (flattened and low dissected part of Madhupur terrace) with Narrow and wide Valley surrounded by Marshy Land and Floodplain. The Geological Survey of Bangladesh (GSB) in collaboration with German Federal Institute for Geosciences and Natural Resources (BGR) for the project "Building ground information system, Dhaka City, Bangladesh" developed a Geomorphologic Map to serves as a base for the Urban Geology Map for urban planning. From the Geomorphologic Map, the geological characteristic of Purbachal can be observed.

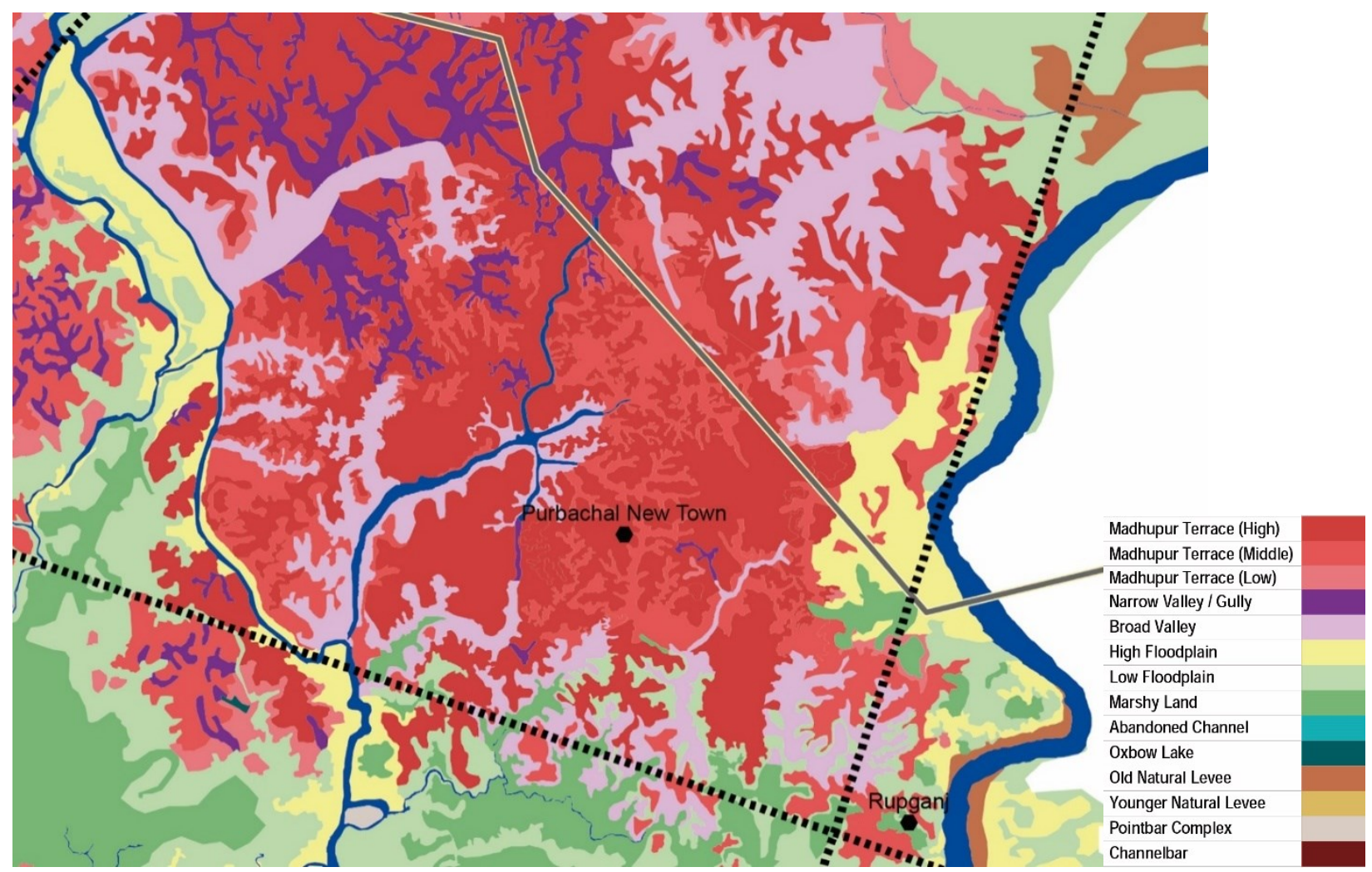

Figure 5.3: Geomorphologic map of greater Dhaka city (Source: Geological Survey of Bangladesh, 2014)

This map provides valuable geological information for the future land development. From the map, it is observed that there is a continuous area of Madhupur Terrace where Madhupur Clay is exposed. This landform is on an average $6 \mathrm{~m}$ above from mean sea level. Due to the high elevation, the area remains flood free and suitable for 4 - 6 story infrastructures with a foundation depth of up to $3 \mathrm{~m}$ (GSB \& BGR, 2014). Large and tall infrastructures can also be built in this area supported with the pile foundation. 
However, the existing masterplan proposed intensive development on the high floodplains, as well as in the broad valley areas, without proper consideration of the natural topography of the area. As a result, a huge portion of marshy land and floodplain was filled which transformed the natural geological characteristic of the area.
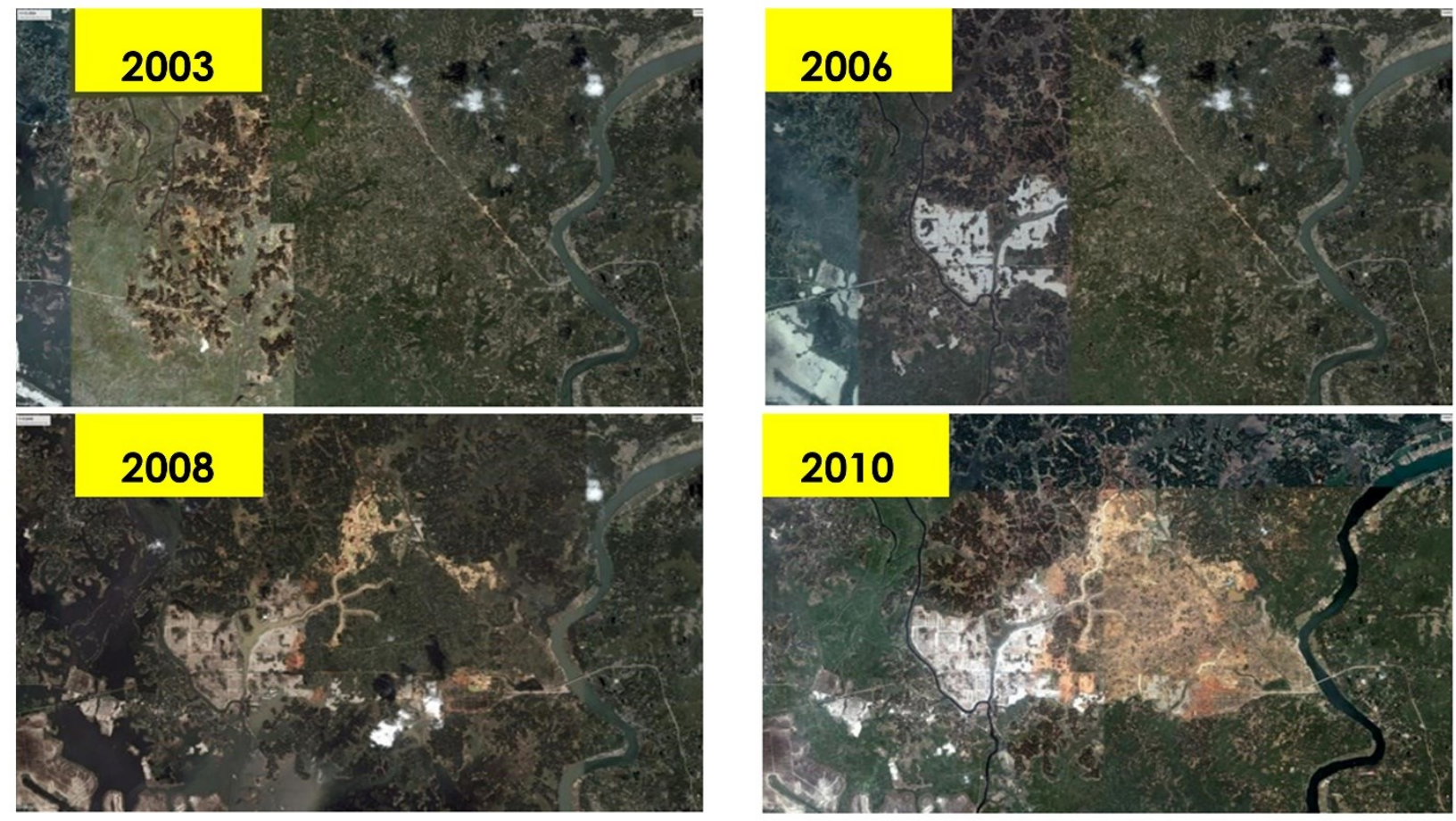

Figure 5.4: Transformation of Purbachal (Google Earth, 2003-2010)

The natural landscape of the selected area was completely changed within the five years since the development started. The low-lying flood plains were filled with sand to create a level foundation. Instead of the free-flowing natural landscape of high and low lands, a formal grid pattern was superimposed as a masterplan for the satellite city.

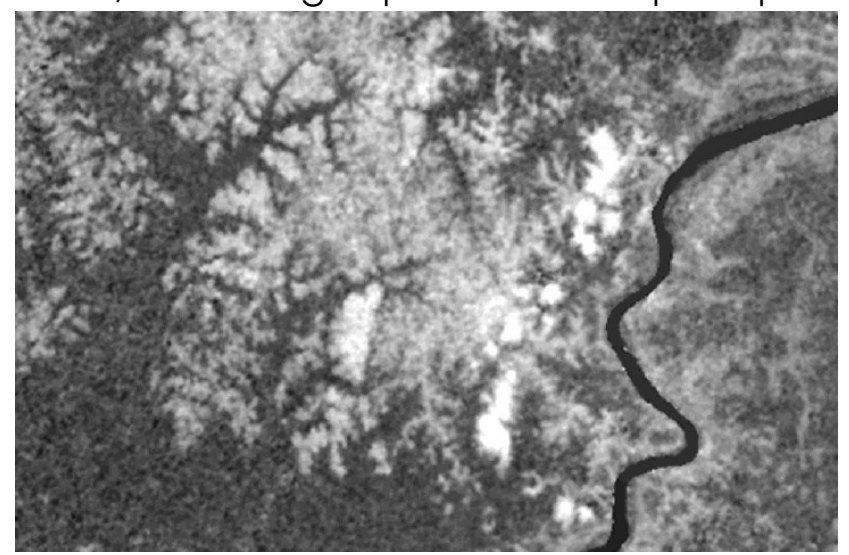

Figure 5.5: Natural topography and current masterplan comparison

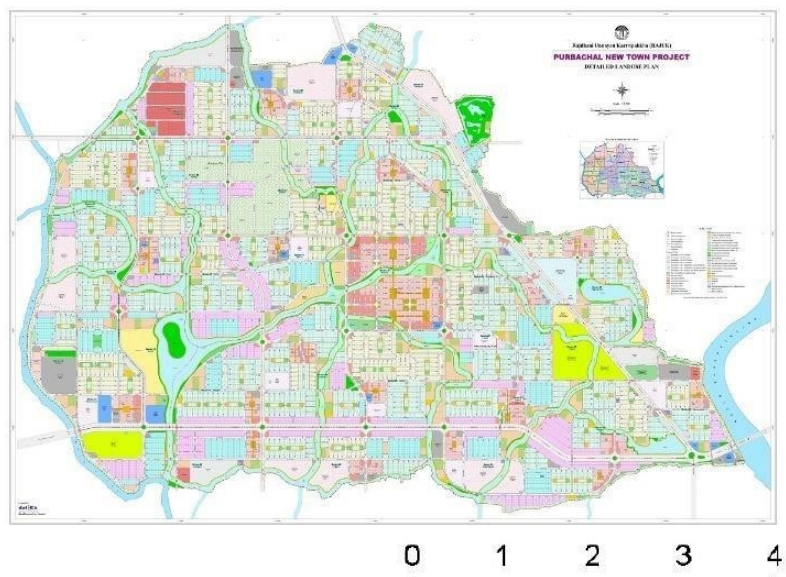

0 


\subsection{Analyzing the Flood Risk}

Historically, the eastern part of Dhaka is susceptible to recurrent flooding and waterlogging during monsoon season almost every year. By acting as a water retention area for the greater Dhaka metropolitan area, the eastern floodplains played a crucial role to mitigate the impact of flooding and reduce losses in the other parts of the city.
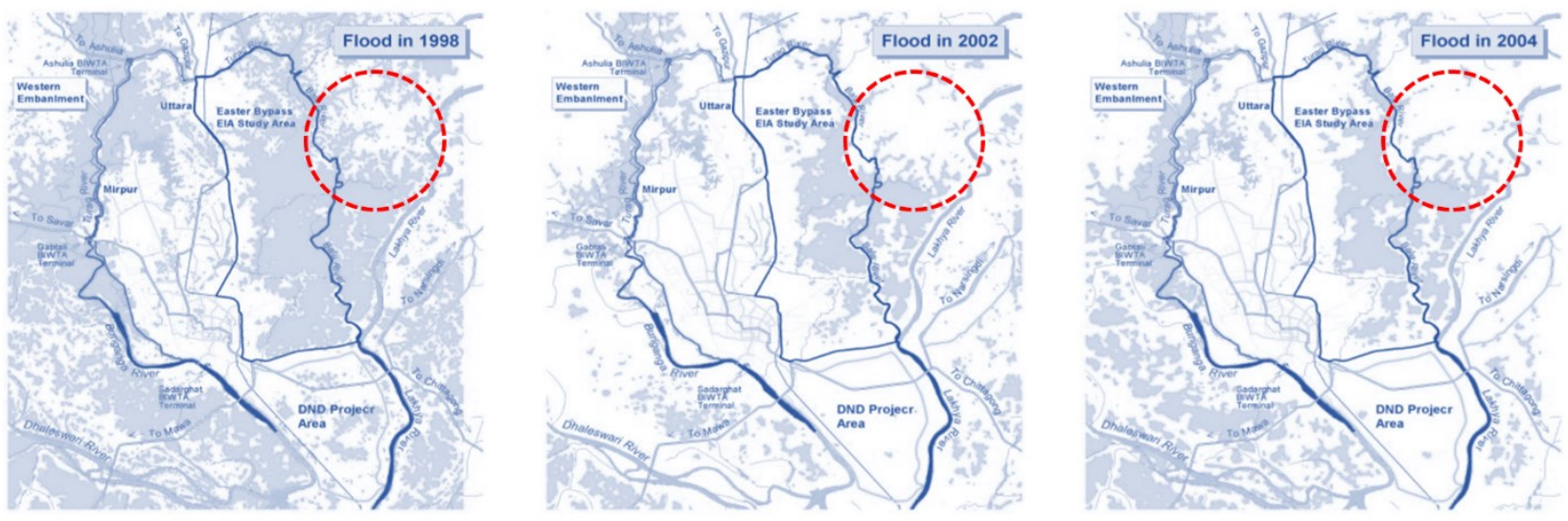

Figure 5.6: Inundated Areas in 1998, 2002 and 2004 Floods, Source: (Deveroy S B, 2008.)

A major part of the Purbachal area falls under the eastern floodplain. The adjacent rivers take the water to the south to the south-east direction (Rahman, 2008). As Purbachal is in the upstream of Dhaka, any change in the hydrological context of Purbachal will have a profound influence on the Dhaka city downstream. From previous studies it was evident that many of the eastern and southern parts of the Purbachal fell under the high to very high-risk flood zones (Dewan, 2007).

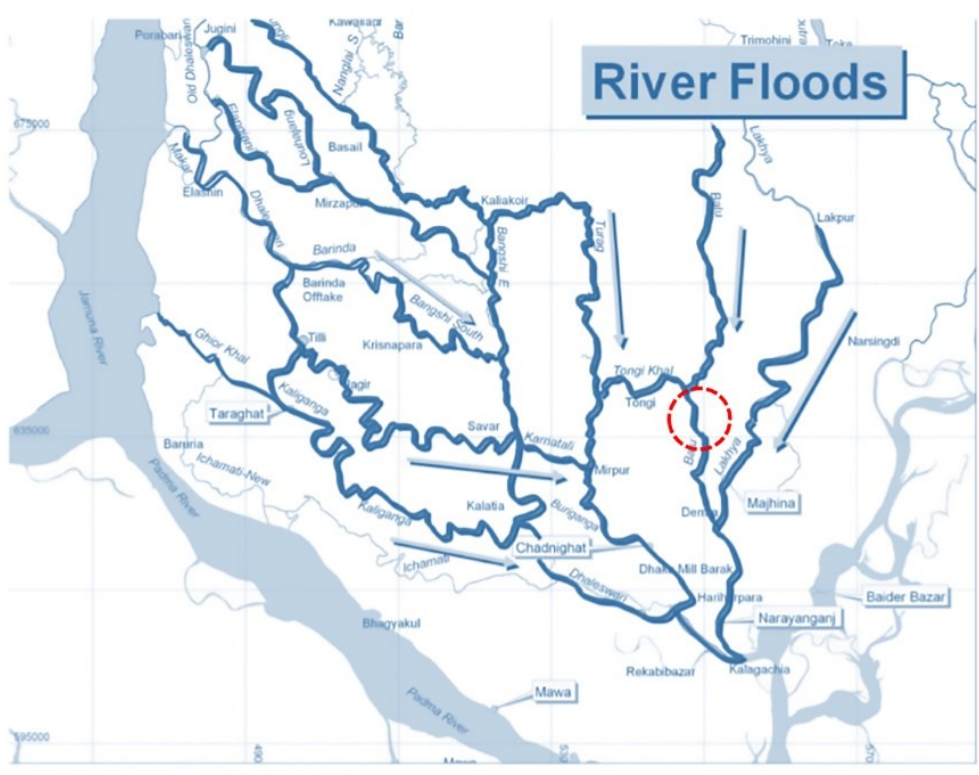

Source: Rahman SMR, 2008

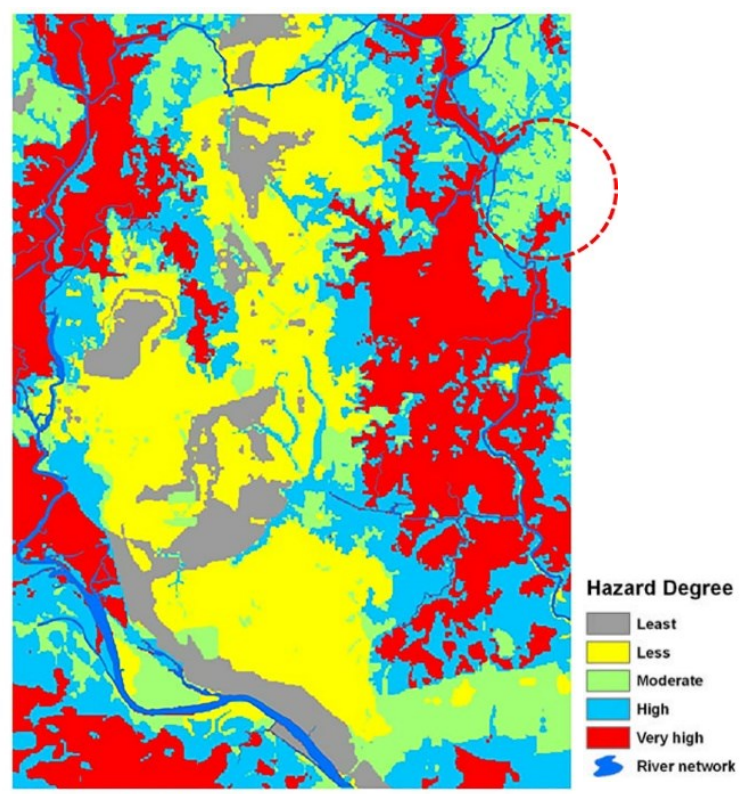

Source: Dewan, 2007

Figure 5.7: River flow direction and flood hazard map of greater Dhaka 


\subsection{Analyzing Risk from Earthquake}

The Greater Dhaka is exposed to high seismic activity. The city is located within 60 kilometers of the Madhupur fault line. In the past 200 years, Dhaka was hit by over fifteen earthquakes with the highest recorded magnitude of 8.1 during the Great Indian Earthquake, 1897. The nature of the soil determines which area is more vulnerable during a major earthquake. Soft soil amplifies the strength of the ground shaking and as the softness of the soil increases, the likelihood of the earthquake strength increases accordingly. In areas that are filled up with sand, the vibration from an earthquake can convert soils with sand grains from the solid to a liquid state, which is known as the soil liquefaction process.

\section{Soil liquefaction}

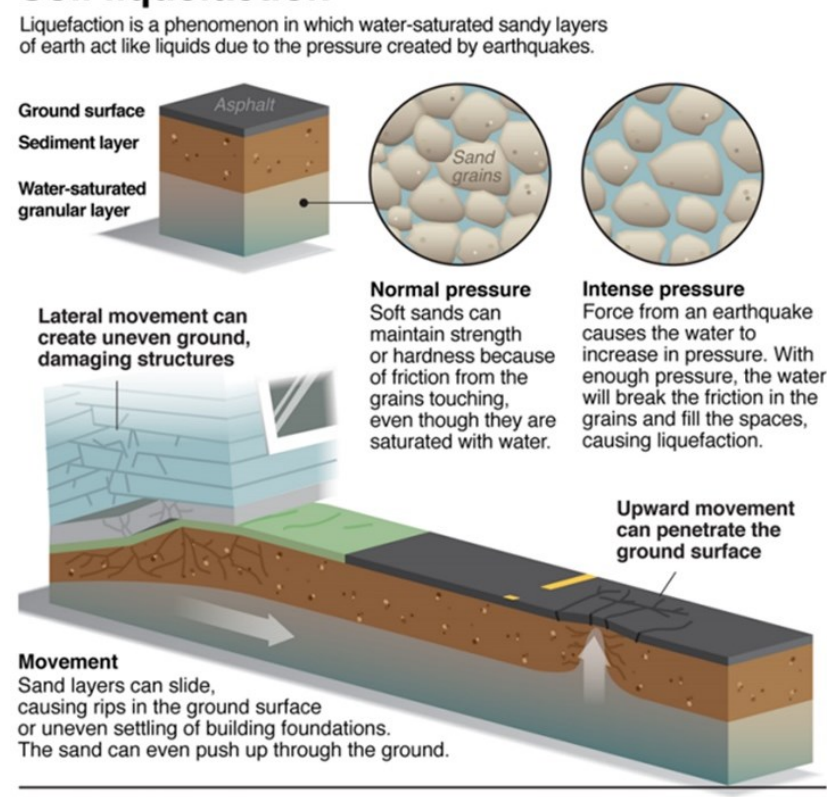

Source: California Watch research

BRIAN CRAGIN / CALIFORNIA WATCH

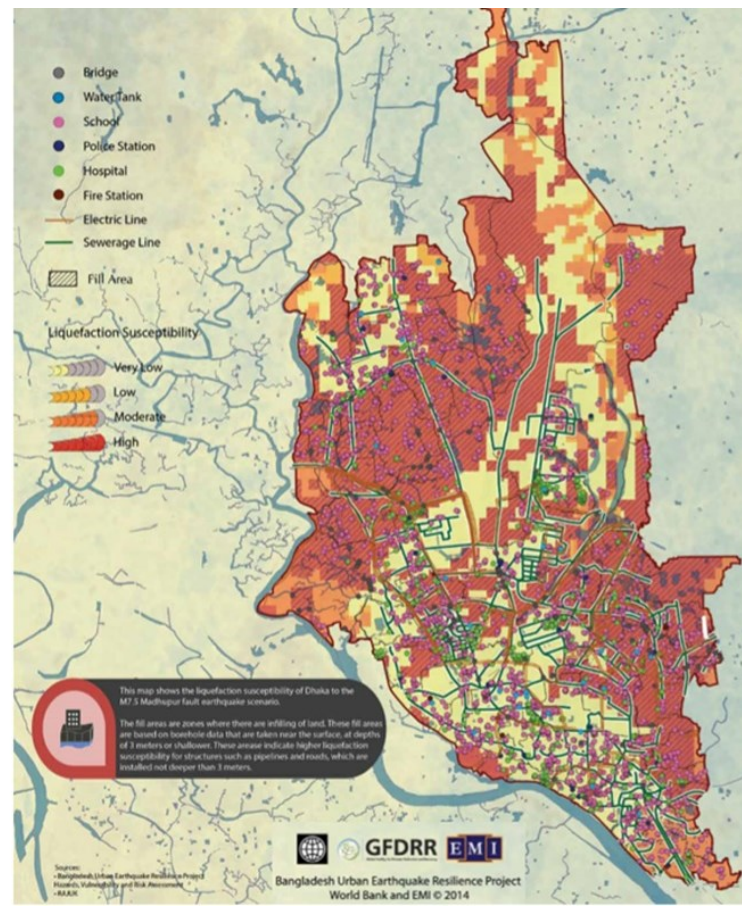

Figure 5.8: Soil liquefaction susceptibility map of Dhaka (Source: Bangladesh Urban Earthquake Resilience Project)

According to the liquefaction susceptibility map developed by the Bangladesh Urban Earthquake Resilience Project (2014), most of the filled-up areas of Dhaka city fall into the high-risk category of soil liquefaction. About 40 percent of Eastern Dhaka lie outside the Madhupur Tract, which makes the area susceptible during a major earthquake event (Bird et al., 2018).

Instead of addressing this risk, the Purbachal masterplan proposed new development areas by sand filling low-lying areas rapidly. The low floodplains and the marshy lands have soft soil which can amplify ground shaking in the event of an earthquake (Bird et al., 2018). Sand filling these areas will further increase the risk of soil liquefaction. This may lead to a catastrophic event where many buildings and major infrastructures can sink as the soil may no longer be able to support loads during a major earthquake. 


\subsection{Analysis of Previous Masterplan}

'Dhaka Improvement Trust' (DIT) established in 1956 was the first authority for planning and controlling development within its jurisdiction. After disbandment of DIT, The Rajdhani Unnayan Kartripakkha (RAJUK) was established in 1987 to develop, improve, extend and manage the city. The planning authorities oversees developing masterplans for the greater Dhaka Metropolitan area. The most significant planning approaches (DIT-RAJUK) are as below:

- The Master Plan for Dhaka, 1959.

- Dhaka Metropolitan Area Integrated Urban Development Project (DMAIUDP), 1981.

- Dhaka Metropolitan Development Planning (DMDP), 1995-2015 - Structure Plan (1995-20015) - Urban Area Plan (1995-2007) - Detailed Area Plan (DAP) (2010-2015

- DHAKA STRUCTURE PLAN 2016-2035

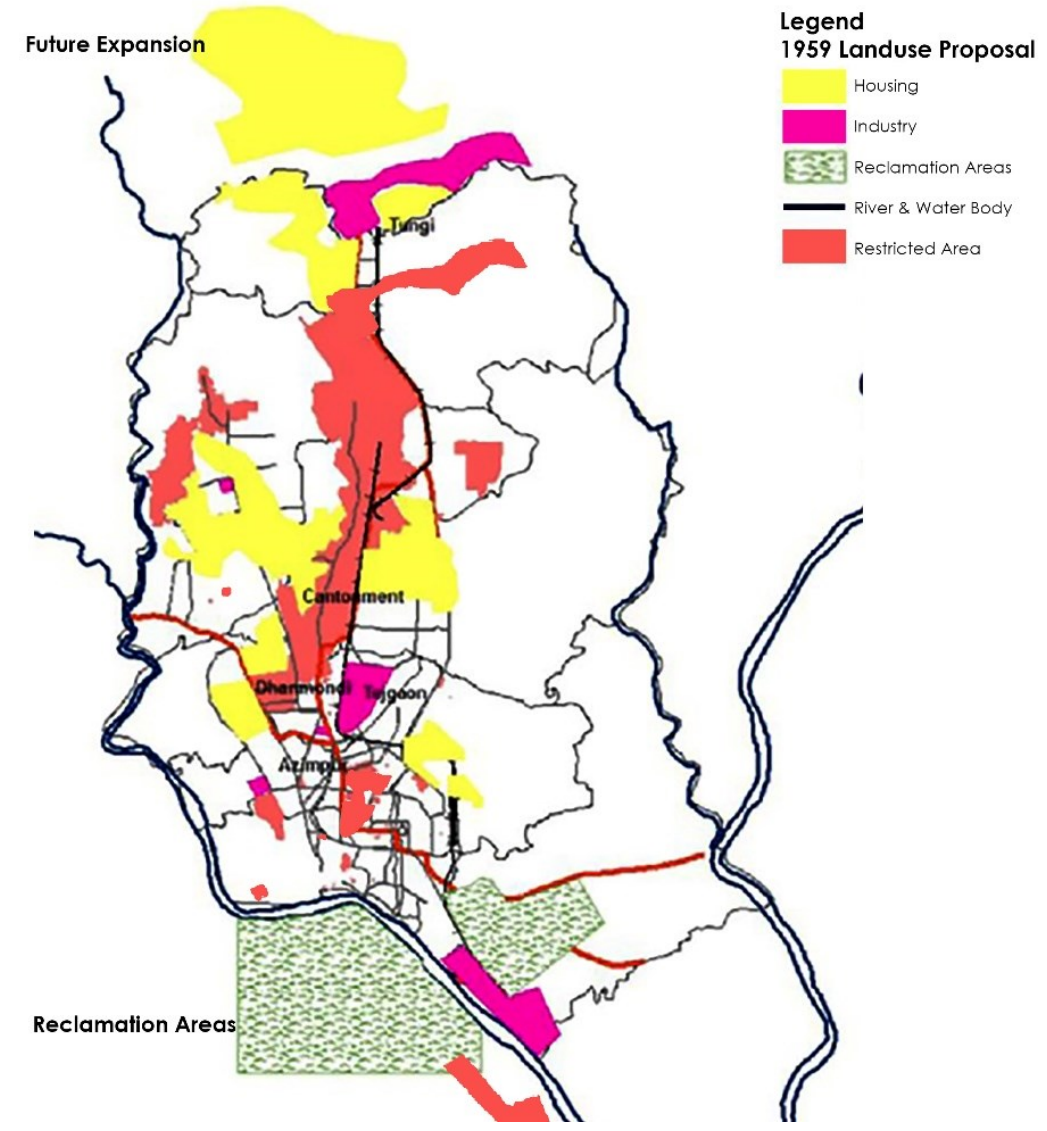

Figure 5.9: The Master Plan for Dhaka, 1959 (Source: Adapted from Kabir et al. 2012)

The first Dhaka Master Plan was prepared in 1959 under supervision of the Dhaka Improvement Trust (DIT) for a target period of twenty-years from 1959 to 1979. The Master Plan proposed major expansion of the city was largely toward the north and a largescale of reclamation area was proposed at Keraniganj, Postogola and part of DND triangle. Due to availability of funds and weak institutional capacity, the Master Plan could not be implemented which eventually lead to uncontrolled development in the Dhaka city. 
Dhaka Metropolitan Area Integrated Urban Development Plan (DMAIUDP) was the second Master Plan for Dhaka in 1981. The plan recommended expanding urban development towards north to accommodate a population of 9 million by 2000 . The masterplan proposed three alternative strategies for the long-term growth of Dhaka.

(1) Comprehensive Flood Protection,

(2) Peripheral Growth, and

(3) Northern Expansion (Figure 5.10).

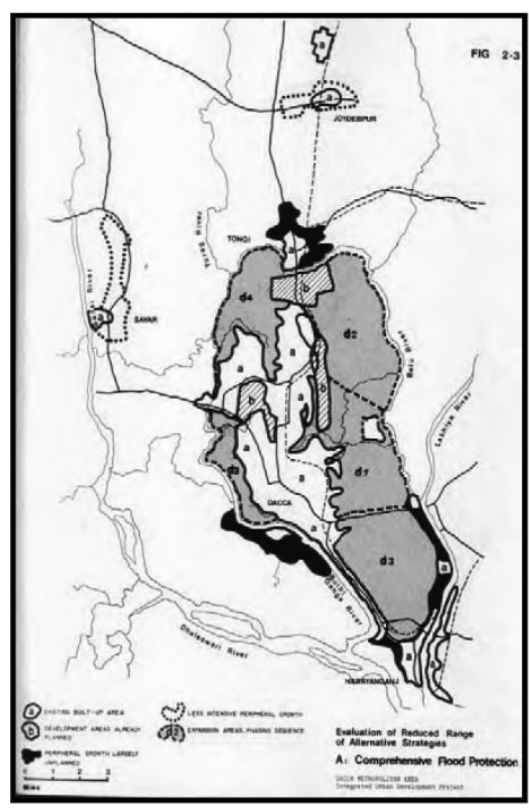

Comprehensive Flood Protection strategy

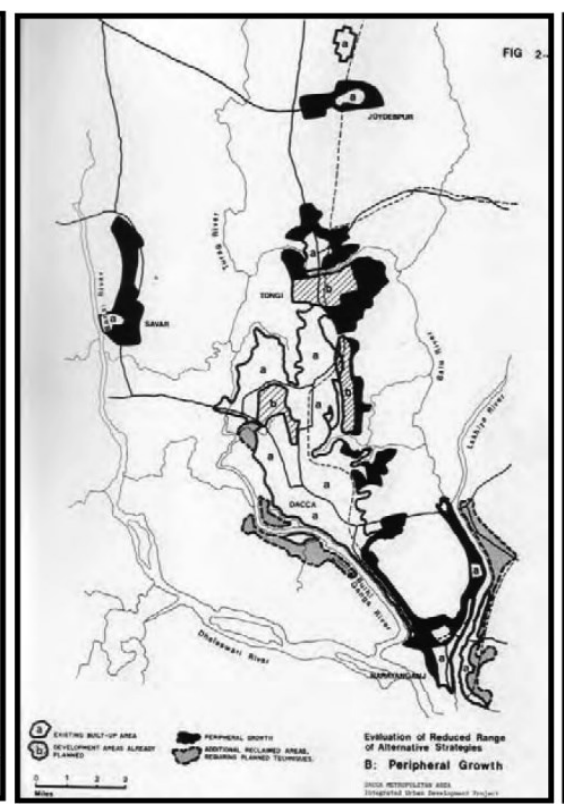

Peripheral Growth Strategy

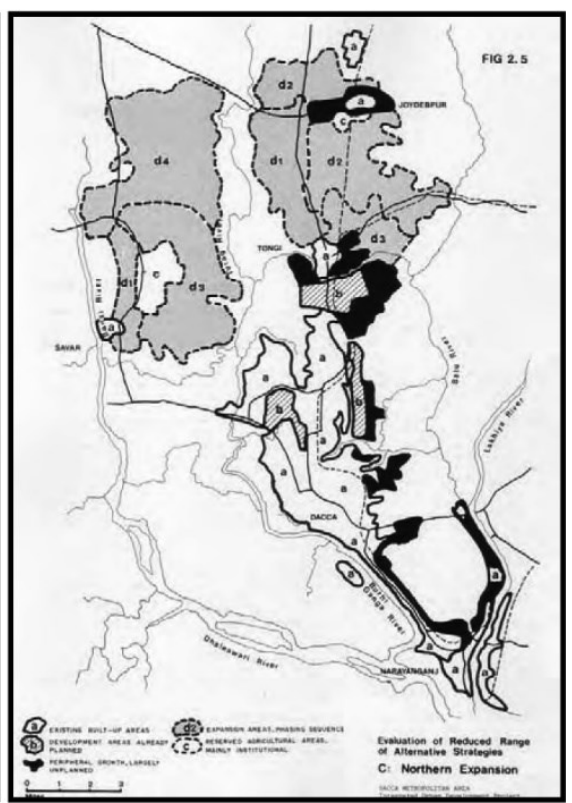

Northern Expansion Strategy

Figure 5.10: Alternatives of Growth Strategy for Urban Expansion in DMAIUDP (Source: Dacca Metropolitan Area Integrated Urban Development Project, 1981)

The masterplans of 1959 and 1981 strategically focused on urban expansion proposals towards the northern parts of Dhaka. The higher elevated flood-free area in north Dhaka had the potential to minimize development pressure on the urban core (Ahmed et al. 2014). Unfortunately, the 1981 masterplan did not account for the population increase due to local migration while proposing the expansion strategies. As a result, the plan failed to control the growth of the city, and the need for new developable land increased.

In the Dhaka Metropolitan Development Plan 1995-2015, proposed new strategies to develop satellite town around Dhaka metropolitan area. A feasibility study was carried out for the priority areas of the eastern part of Dhaka. In this plan, Purbachal was proposed as one of the planned projects for the future. Though the general location for the project was included in the masterplan, no project boundary was designated. Also, the surrounding area on the east, west, and south was designated as the main flood flow area. 


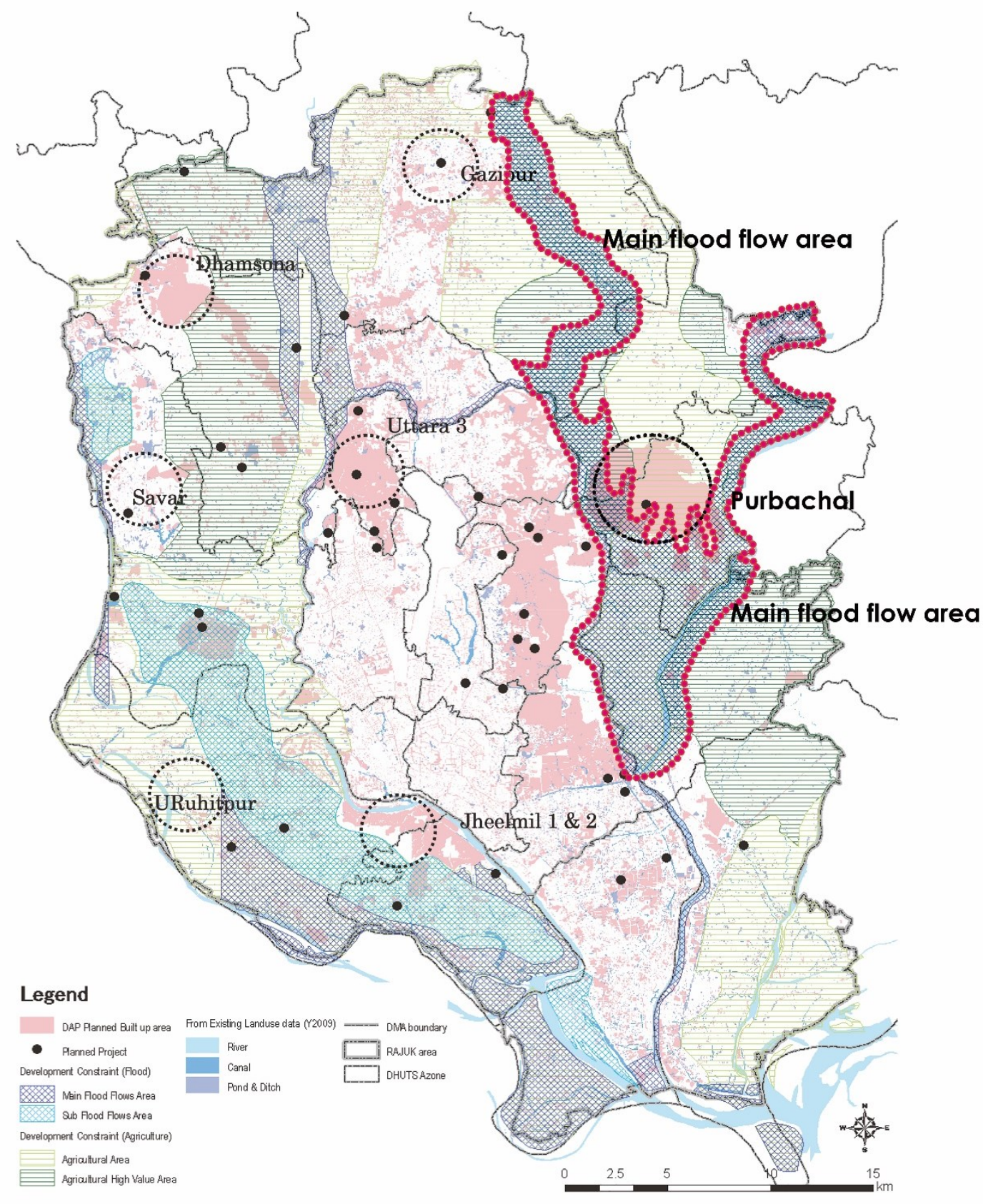

Figure 5.1 1: Dhaka Metropolitan Development Plan 1995-2015 (Source: Prepared by the DHUTS, based on Structure Plan of DMDP, 1995)

As the surrounding areas of Purbachal fall in the flood flow zone, it was important to design the new town according to the topographical context. But the Purbachal masterplan developed by Rajuk completely ignored the site context and followed a rigid grid layout. The natural topography was modified to create a flat terrine by cutting and filling. Areas designated as the main flood flow area was sand filled. This violated the Dhaka Metropolitan Development Plan 1995-2015. 
To accommodate the violations of the Landuse plan of Purbachal, 2012, in the new Dhaka Structure Plan 2016-2035, Purbachal was marked as an Outer Urban Area and the Hierarchy Type was a Regional Centre. The northern areas of Purbachal marked as main flood flow areas in the previous masterplan was marked as a conservation area in the new structure plan. But if we compare both plans, it can be seen how the main flood flow area was interrupted by the masterplan of Purbachal.

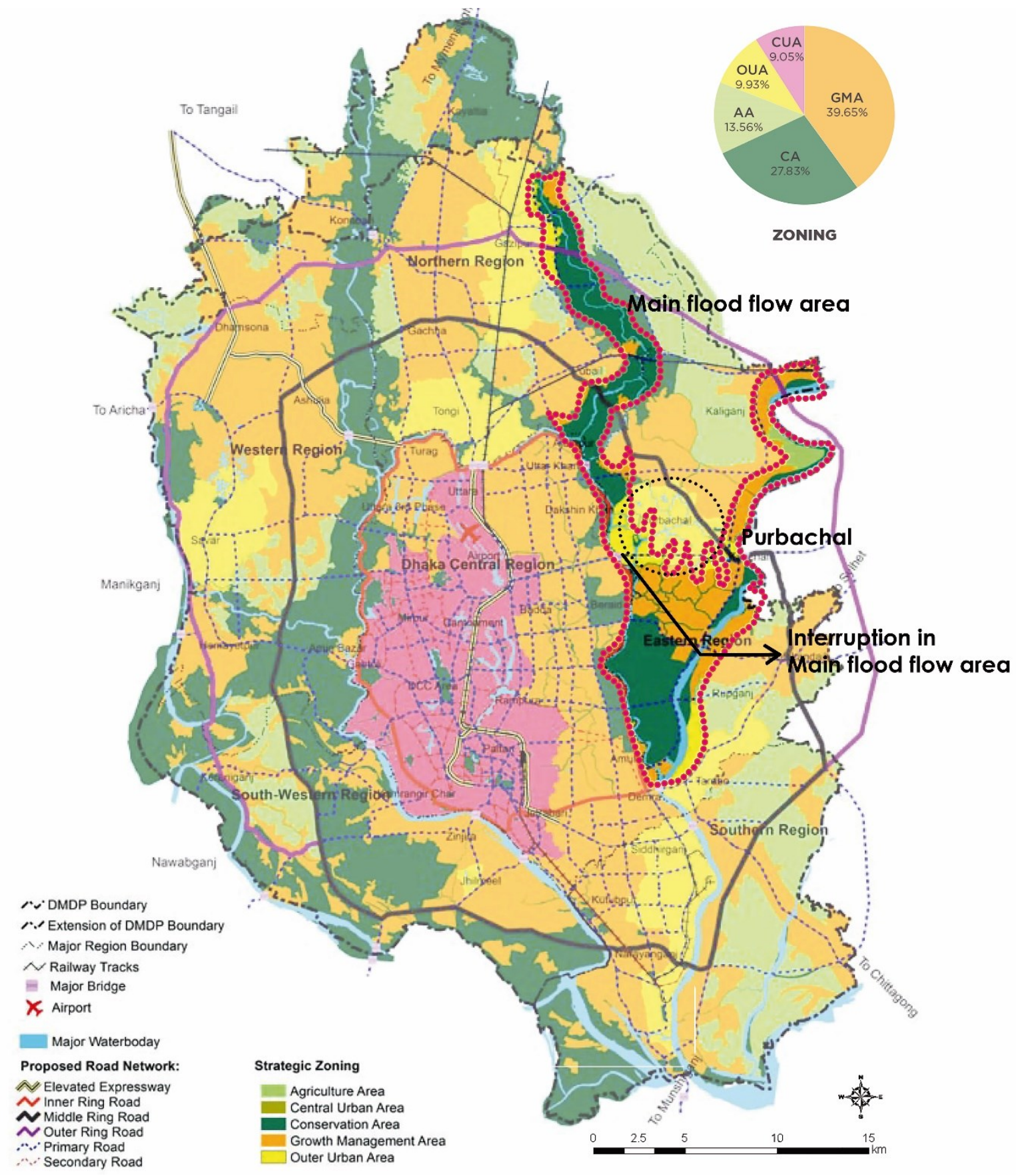

Figure 5.12: Dhaka Structure Plan 2016-2035 (Source: Dhaka structure plan 2016-2035) 


\subsection{Questions for the current development plan}

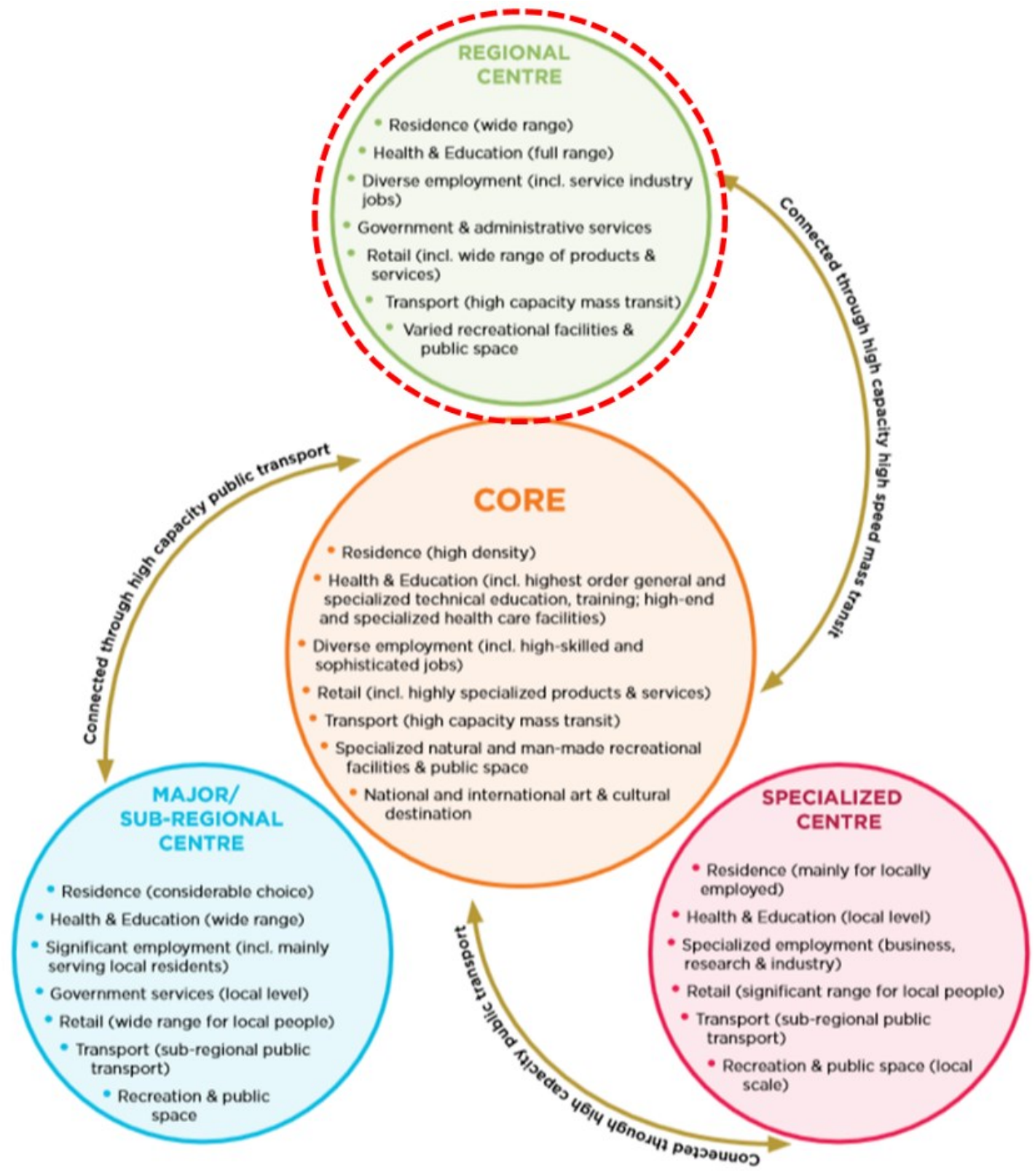

Figure 5.13: Range of services and connectivity for strategic centers, (Source: Dhaka structure plan 2016-2035 | Page 52)

In the Dhaka structure plan, Purbachal has been proposed as a Regional center. To serve this role, the new town masterplan must have certain amenities that ensure a selfsufficient city that can provide both housing and work opportunities for the residents along with other basic civic services. 
Therefore, this study needs to analyze whether the Purbachal New Town masterplan has the following features:

- Public transportation, cycling and walking, and dissuaded the use of cars.

- Accessibility for everyone, including people with disabilities.

- Efficient use of energy and a reduction in greenhouse gas emissions.

- Adequate and quality public open space.

- Green infrastructures and environmental sustainability.

- Safety and minimized crime in the neighborhoods.

- Attractive and well-maintained appearance.

- Social integration and a diverse range of household types that fulfill the needs of different age groups, family structures, and socioeconomic situations.

- Protected, and where possible enhanced, the built and natural, and cultural heritage

\subsection{Major drawbacks with the current masterplan}

By analyzing the previous masterplans and assessing the risks related to urban flooding and earthquake, the following drawbacks of the current Purbachal New Town masterplan can be found:

- Failures of the past development plans were never evaluated

- Lessons learned from the failures of the past developments were not included in the new masterplan

- The plan is mainly focused on creating developable land and maximizing residential plots without considering the natural hydrology and environmental impact

- Not a continuation of immediate past plan

- Natural systems and responsive human needs were sidelined

- Do not meet the national physical policies and planning standards

- Current issues due to the past blunders, such as water logging and traffic congestions, were not addressed at all

- Do not provide alternative plans on public transportation to reduce vehicular transportation

- Do not address environmental hazards such as flooding issues and earthquakes

- Lack visions and strategies for implementation

To develop with a master plan that meets the requirements of a regional center and addresses the drawbacks of the current masterplan, it is necessary to properly analyze the pre and post-development scenario of Purbachal and develop a plan that follows the topographical context. 


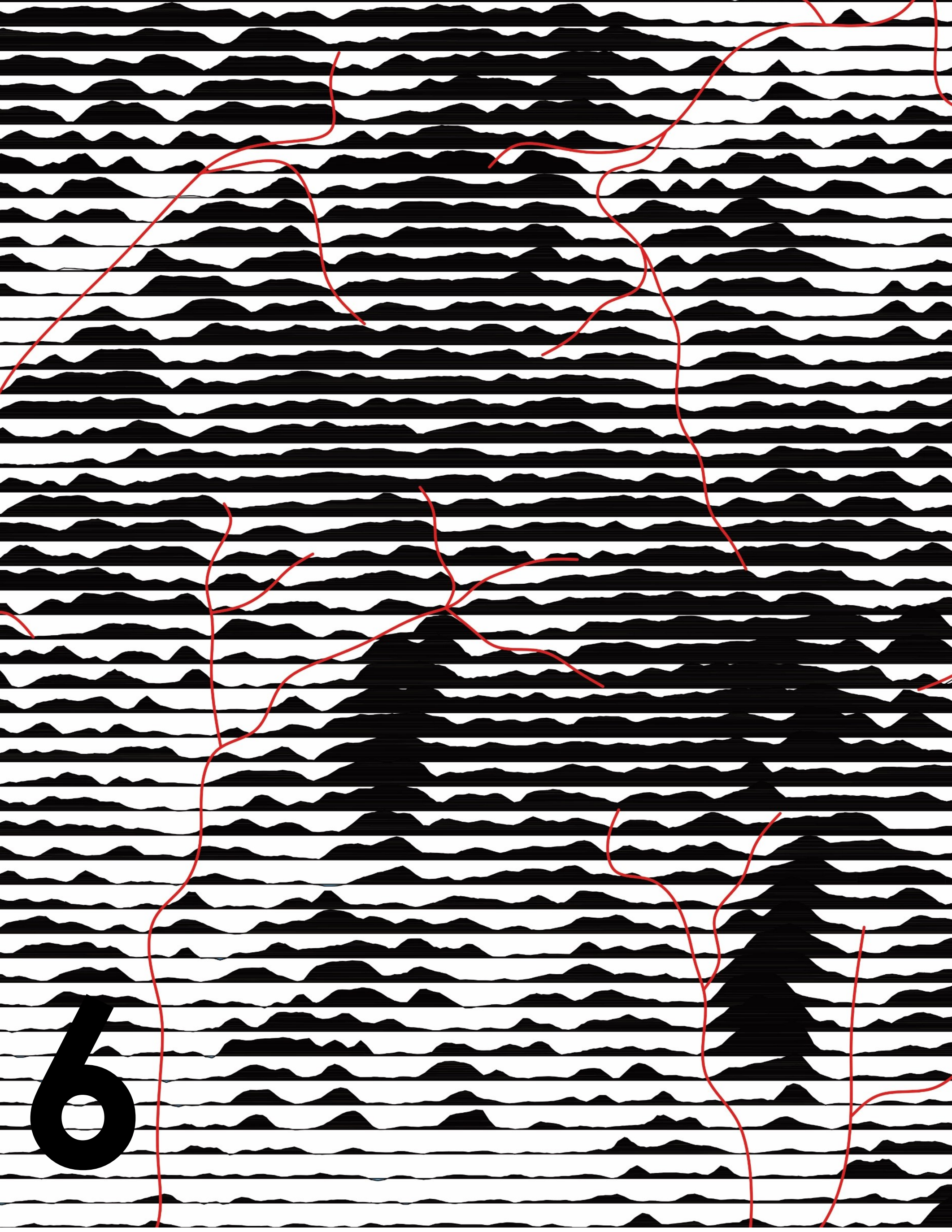




\section{Chapter 6 New Masterplan and Design Guideline}

\subsection{Program requirements}

\begin{tabular}{lcc}
\multicolumn{1}{c}{ LandUse } & Acre & $\begin{array}{c}\text { Percentage } \\
(\%)\end{array}$ \\
Administrative & & 2.51 \\
Commercial & 151.472 & 3.49 \\
Community Organization & 210.766 & 0.47 \\
Education & 28.441 & 4.03 \\
Forest and Eco-Park & 243.648 & 2.76 \\
Heath & 166.481 & 0.47 \\
Industrial Park & 28.123 & 1.56 \\
Pedestrian & 93.978 & \\
& & 2.18 \\
Physical Infrastructure & 131.666 & 2.36 \\
Play-Ground/Play-Lot & 142.527 & 0.59 \\
Plaza & 35.657 & 0.40 \\
Research and Institutional & 23.874 & 1.63 \\
Residential Block & 98.455 & 5.61 \\
Residential Plot & 338.796 & 33.13 \\
Road & 2001.680 & 23.63 \\
Social Infrastructue(SIS) & 1430.484 & 1.50 \\
Sports Facilities & 90.892 & 1.88 \\
Urban Green & 113.281 & 3.85 \\
Urban Utility Facilities & 232.709 & 0.75 \\
Water-Body & 45.353 & 7.16 \\
Wakf Land & 432.475 & 0.00 \\
GRAND ToTAL & 0.298 & 100.00 \\
& 6040.756 & \\
\hline
\end{tabular}

Table 4: Land use distribution in Purbachal master plan. (Source: www.rajuk.gov.bd)

The existing program for the Purbachal master plan was taken as the base for the design program formulation. The existing program heavily periodized the residential development. The proposed masterplan has created a balance among various land uses by creating connections among different elements of physical infrastructures with natural entities to create a climate resilient city.

The development plan incorporates dense urban development strategies while promoting connections with natural elements to create a climate resilient biophilic city. The guidelines for Biophilic city design were also studied and incorporated with the program requirements. 
1. Visual

Connection with Nature

View to elements of nature, living systems and natural processes

\section{Non-Visual \\ Connection \\ with Nature \\ Sounds, touch, \\ smells, or tastes that \\ engender a positive reference to nature}

\section{Non-Rhythmic}

Sensory Stimuli

Objects or materials

in consistent yet

unpredictable motion as found in nature (e.g: grass swaying/ripples on water/leaves in a breeze)

\section{Thermal \&} Airflow Variability

Changes in air temperature, humidity airflow across the skin and surface temperatures that mimic natural environments

\begin{tabular}{|c|c|}
\hline Biophilic Design Pattern & Biophilic Design Pattern \\
\hline $\begin{array}{l}\text { 5. Presence } \\
\text { of Water } \\
\text { Seeing, hearing or } \\
\text { touching of water }\end{array}$ & $\begin{array}{l}\text { 8. Biomorphic } \\
\text { Forms \& Patterns } \\
\text { Contoured, patterned, } \\
\text { textured or numerical } \\
\text { arrangements that } \\
\text { mimic nature }\end{array}$ \\
\hline $\begin{array}{l}\text { 6. Dynamic and } \\
\text { Diffuse Light } \\
\text { Varying intensities of } \\
\text { light and shadow that } \\
\text { change over time to } \\
\text { mimic natural patterns } \\
\text { and cycles }\end{array}$ & $\begin{array}{l}\text { 9. Material } \\
\text { Connection } \\
\text { with Nature } \\
\text { Materials and elements } \\
\text { from nature that reflect } \\
\text { local ecology/ geology } \\
\text { to create sense of } \\
\text { place }\end{array}$ \\
\hline $\begin{array}{l}\text { 7. Connection with } \\
\text { Natural Systems } \\
\text { Awareness of natural } \\
\text { processes such as } \\
\text { seasons and temporal } \\
\text { changes }\end{array}$ & $\begin{array}{l}\text { 10. Complexity } \\
\text { and Order } \\
\text { Rich sensory } \\
\text { information that } \\
\text { adheres to a spatial } \\
\text { hierarchy similar to } \\
\text { nature }\end{array}$ \\
\hline
\end{tabular}

\section{Risk/Peril}

Identifiable threat to create tension paired with reliable safeguard

Figure 6.1: Elements of Biophilic design 


\begin{tabular}{|c|c|c|c|c|}
\hline Population Calculations & & Open Space Calculations & & \\
\hline & & & Existing & Proposed \\
\hline Average unit size & $1000 \mathrm{sft}$ & Urban Green & 232.7 & 1695.5 \\
\hline Average person in a household & 4 & & & \\
\hline Average plot size & 5 katha $=3600 \mathrm{sft}$ & Waterbody & 437.5 & 1612.2 \\
\hline \multirow[t]{2}{*}{ Maximum ground coverage } & $50-60 \%$ & & & \\
\hline & & Forest and Eco-park & 166.5 & 617.9 \\
\hline Number of 5 katha plot in per acre & 12 & & & \\
\hline ( 1 acre $=43560 \mathrm{sft})$ & & Total & 836.7 & 3925.6 \\
\hline Residential Plot & 2279.1 & Estimated total population & & \\
\hline Mixuse Residential & 759.5 & Estimated population in previous design & 1500000 & \\
\hline Mixuse Commercial & 806.3 & If only walkup is considered ( 5 storied) & 1652033.079 & \\
\hline (If $50 \%$ is residential) & 403.15 & If only high-rise is considered ( 10 storied) & 3304066.158 & \\
\hline \multirow[t]{10}{*}{ Total residential area (in Acre) } & 3441.7 & & & \\
\hline & & Open space per person (in $\mathrm{m} 2$ ) & & \\
\hline & & Previous design & 2.3 & \\
\hline & & If only walkup is considered ( 5 storied) & 9.6 & \\
\hline & & If only high-rise is considered (10 storied) & 4.8 & \\
\hline & & & & \\
\hline & & ( 1 acre $=4046.86 \mathrm{sqm})$ & & \\
\hline & & & & \\
\hline & & & & \\
\hline & & & & \\
\hline If only walkup is considered ( 5 storied) & & If only high-rise is considered ( 10 storied) & & \\
\hline Built area in a typical plot $(3600 \times 60 \%)$ & $2160 \mathrm{sft}$ & Built area in a typical plot $(3600 \times 60 \%)$ & $2160 \mathrm{sft}$ & \\
\hline Number of unit in a plot in each floor & 2 & Number of unit in a plot in each floor & 2 & \\
\hline Population in each floor & 8 & Population in each floor & 8 & \\
\hline Total population in a building & 40 & Total population in a building & 80 & \\
\hline Total population per acre & 480 & Total population per acre & 960 & \\
\hline Estimated total population & 1652033 & Estimated total population & 3304066 & \\
\hline Population density (per acere) & 151 & Population density (per acere) & 303 & \\
\hline
\end{tabular}

Table 5: Population and open space standards

The proposed design prioritizes mixed use developments in residential areas. The people of Bangladesh have a strong connection to street and street activities. Streets act not only as the connection between spaces, but also as a meeting point for the community. By providing designated space for street vendors and introducing commercial activities within the residential zones, the design aims to strengthen the community.

The design promotes connections with natural elements to create a biophilic city. Water has been an intricate part of the life of the people of Bangladesh. The plan proposes to incorporate greenery intertwined with the vast networks of the waterway and make them accessible for recreational purposes. The wetland will support an incredible range of flora and fauna and create a natural habitat for local species. 


\subsection{Detail Land use plan}

Existing Masterplan

Land use

1 Administrative

Rajuk Office

Central Police Line

Thana

Police Line

2 Commercial

Market

Wet Market

3 Health

Hospital

Clinic

Health Center

4 Industrial Park

IT hub

Renewable energy sector

5 Physical Infrastructure

Sewerage Treatment Plant

Solid Waste Dumping Station

Composting Plant

Slaughter House

Graveyard

Drinking Water Treatment Plant

Central Bus Terminal

Powerplant

Urban Facilities

6 Research and Institution

University 1

Medical College

Tourism Institute and Five-Star Hotel

University 2

School and College

7 Residential Plot

3 katha

5 katha

7.5 katha

10 katha

Highrise Apartment

Low Income Housing

Government Officer Housing

Residential Block

8 Social Infrastructure

Fire Station

Bangladesh China Friendship Exhibition Cente

Central Mosque

Central Eidgah

Cultural Hub

Community Center

Mosque

ThurchChurch

Pagoda

Play Groun

Plaza

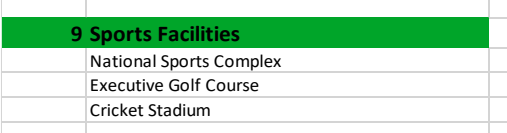

Cricket Stafium

10 Forest and Eco-park

11 Roads

Pedestrian

13 Waterbody
Area (AC) Percentage

151.5

.

28.1

28.1

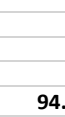

94.0

187.9

\begin{aligned} 78 \\ \hline \\ \hline\end{aligned}

45.4

342.1

\begin{tabular}{|c|}
$\mid+2$ \\
$\mid$ \\
\hline
\end{tabular}

\begin{tabular}{|r|}
\hline 243.6 \\
\hline 2340.5
\end{tabular}

\begin{tabular}{|c|}
\hline \\
\hline \\
\hline
\end{tabular}

.

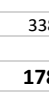

178.9

$+2$

28.

35.7
23.9

113.3

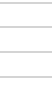

166.5

1562.2

131.7

232.7

437.5
2.5

3.0

\begin{tabular}{|c|}
\hline 2.5 \\
\hline \\
\hline 3.5 \\
\hline
\end{tabular}

0.5

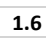

3.1

5.7

38.7

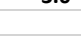

1.9

2.8

25.8

3.8

7.2

Proposed Masterplan

Area (AC) Percentage

$168.0 \quad 1.5$

Land use

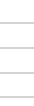

806

81.9

0.7

Health

98.7

0.9

Industrial Park

4.2

Physical Infrastructure

56.5

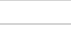

66.1

39.7

56.6

118.8

0.0

476.6

63.3
57.1

\begin{tabular}{l}
57.1 \\
68.8 \\
\hline 34.2
\end{tabular}

68.8
34.2
253.2

253.2

2279.1
759.5

20.9
7.0

Residential Plot

Multimodal Terminal

4.4

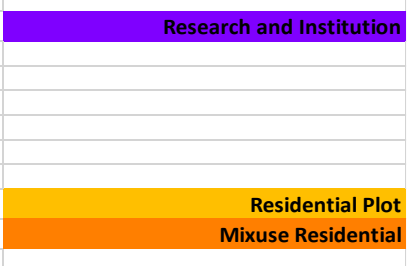

423.5

3.9

Social Infrastructure

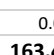

0.0
163.4
73.7
89.7

1.5

Sports Facilities

617.9

5.7

Forest and Eco-park

1276.9

11.7

$\begin{array}{ll}1695.5 & 15.5\end{array}$

$1612.2 \quad 14.8$

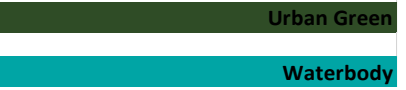

Table 6: Comparison of Existing and Proposed Masterplan Program 

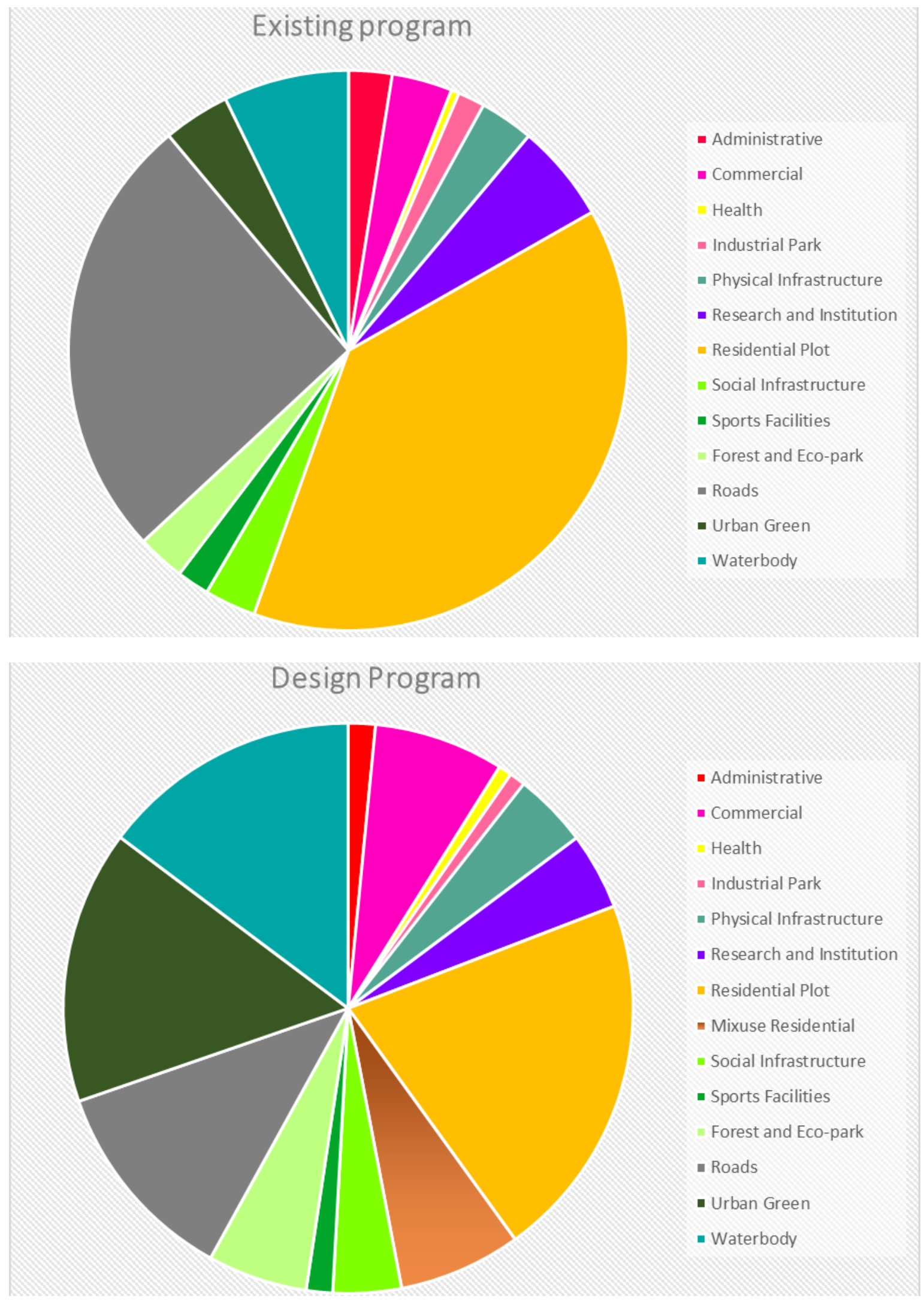

Figure 6.2: Comparison of Existing and Proposed Masterplan Land Use 


\subsection{Land use Plan Comparison}

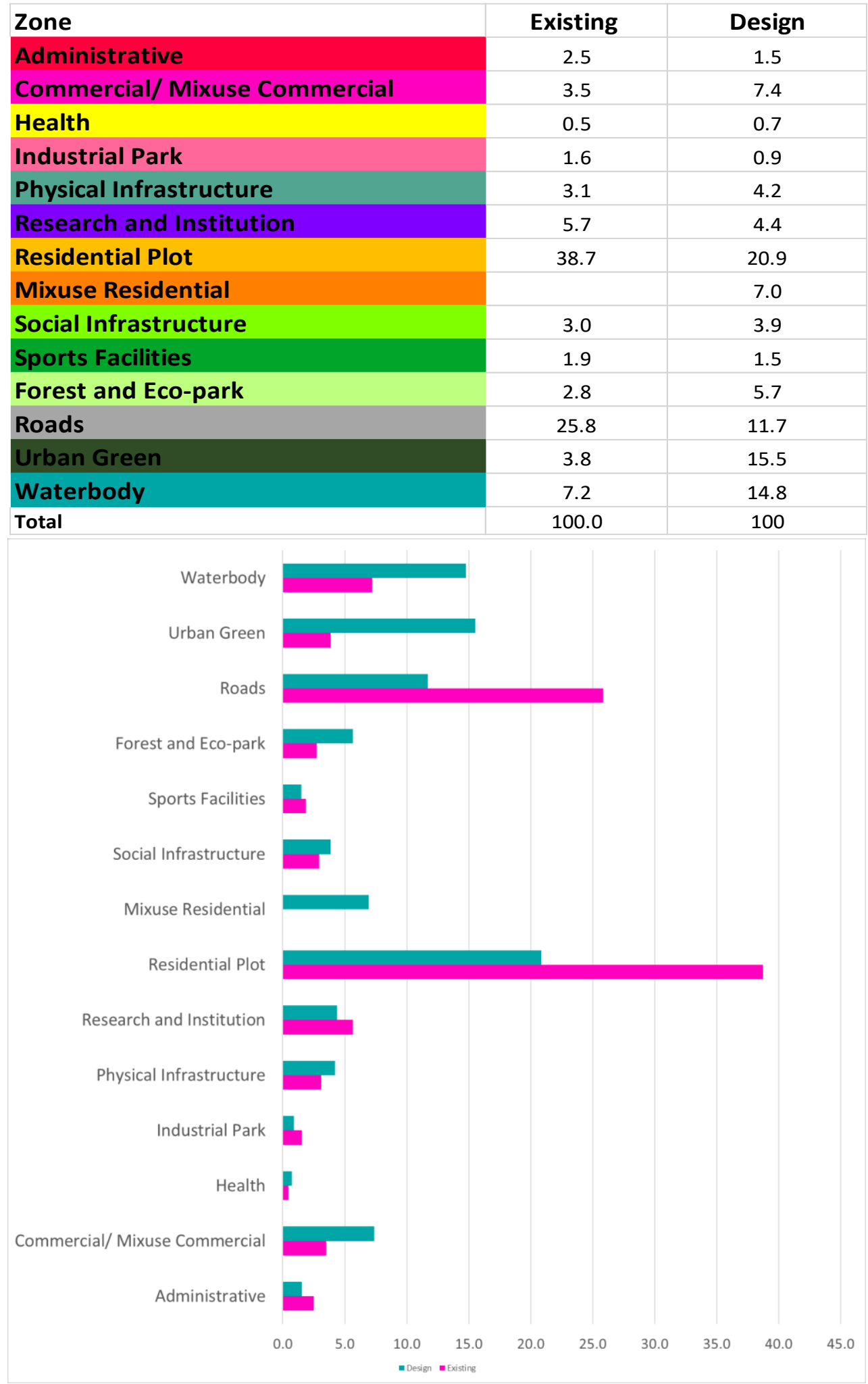

Figure 6.3: Land use Plan Comparison 


\subsection{Design Process}

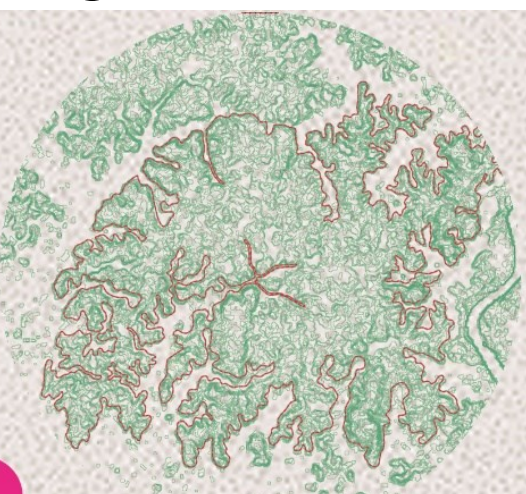

1

Flood-free zone suitable for development

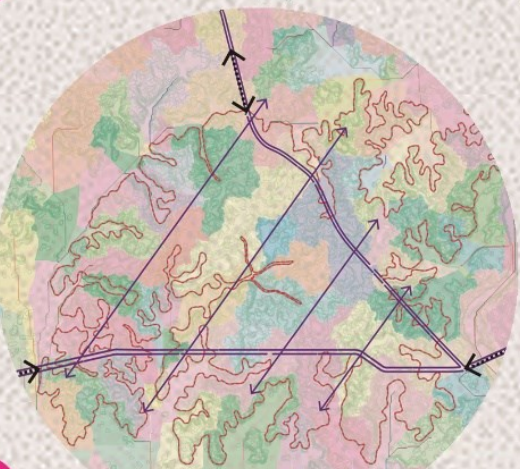

3

Analyzing watershed boundary

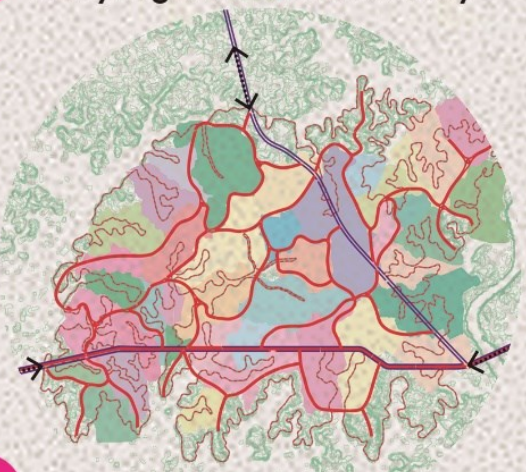

5

Primary road following watershed boundaries

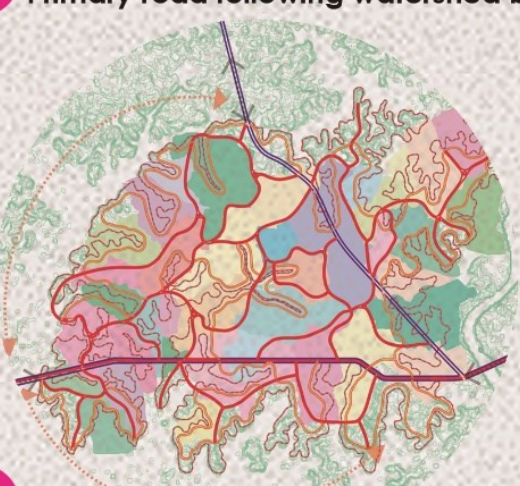

7

Secondary roads defining growth boundary
2

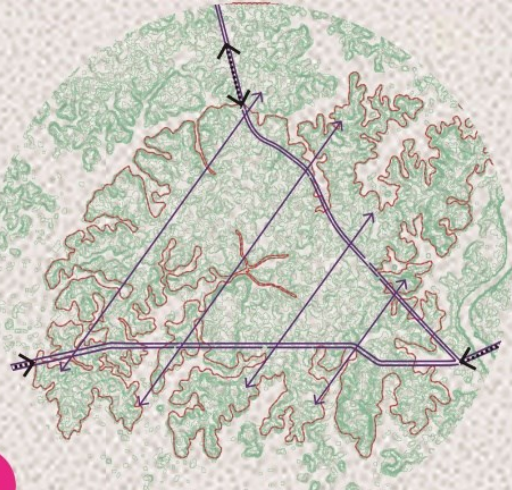

Need new connection with existing road

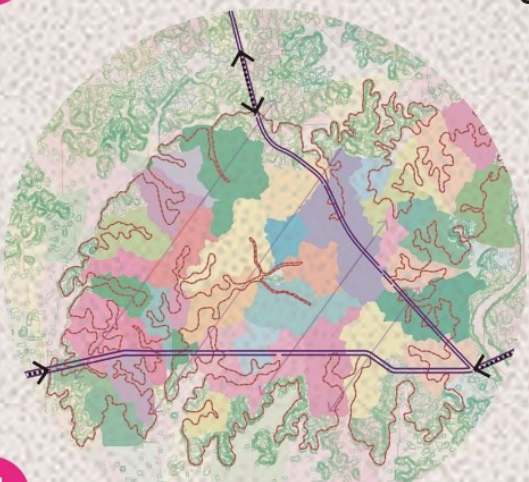

Divide into development zones

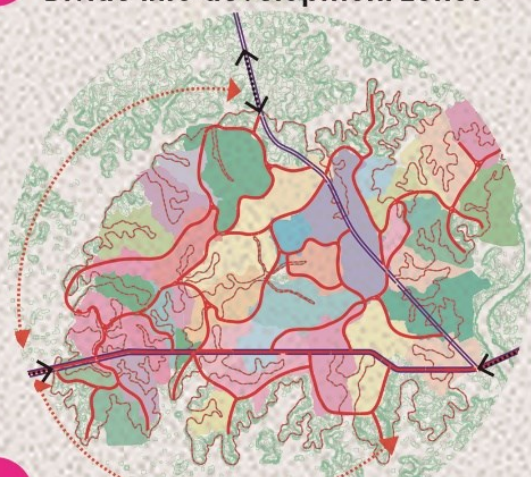

6 Limiting spontaneous growth

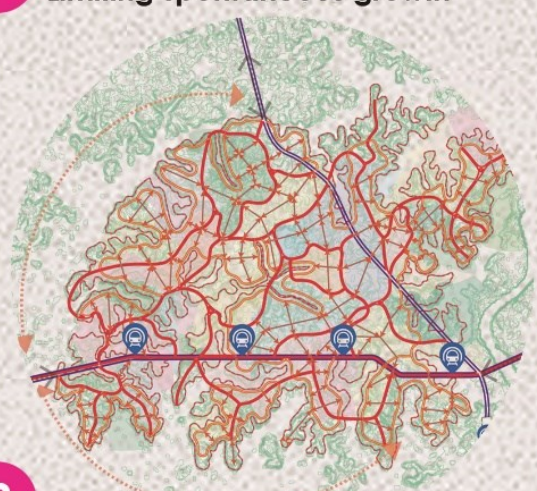

8

Connecting MRT with internal road

Figure 6.4: Design development process 


\section{DESIGN PROCESS}

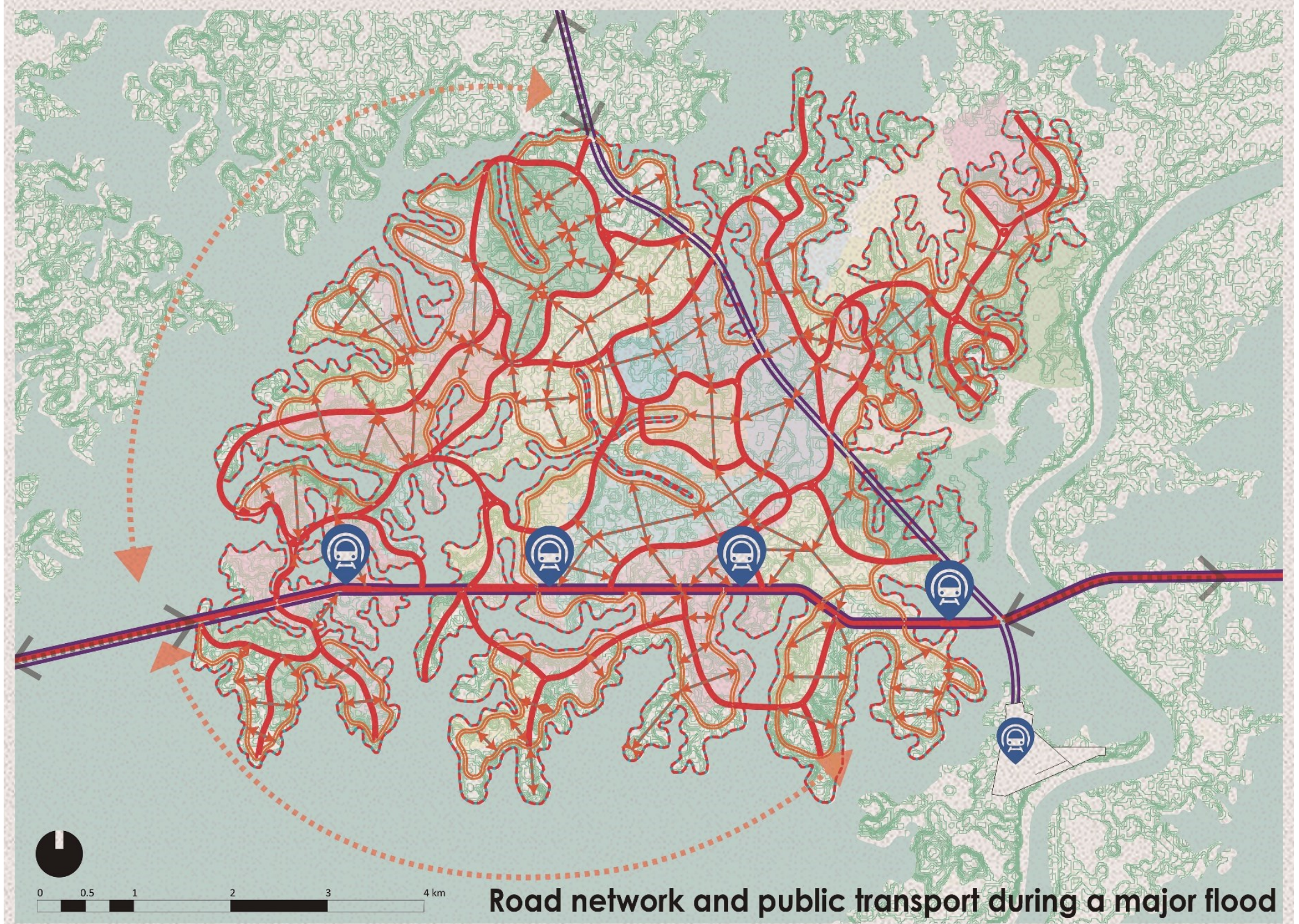

Figure 6.5: Road network and public transportation

By analyzing the results of LULC and Watershed analysis to identify a suitable flood-free area where new development will be possible without drastically modifying the natural systems. The selected area divided into development zones that followed the Watershed boundaries. Main arterial roads are designed to connect these boundaries to create the transportation network. This will ensure that all major roads are at the highest point in a Watershed and will have a higher chance of remaining flood free during a major flood. 


\subsection{Masterplan Zoning}

Administrative

Mix Use Commercial

Mix Residential

F. Community Park

(C) Mosque

(30. Temple

(t) Church

(42) Pagoda

School and College

(4) Health

Industrial Park

Physical Infrastructure

Research Institution

Residential Plot

Social Infrastructure

\section{Sports Facilities}

Urban Forest

(1)

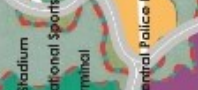

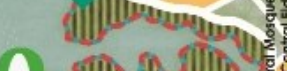

(III) (1) (1)
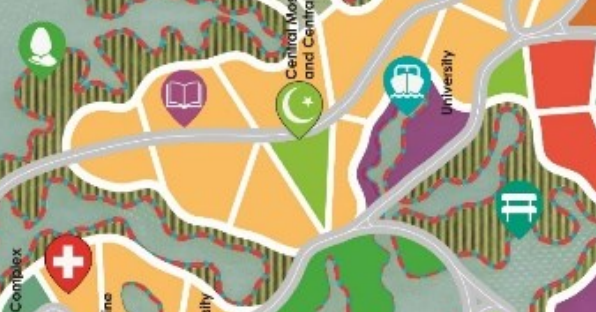

Pedestrian

(2) MRT Station

Ghat

Q Eco-park

Roads

IIIIIII Urban Green

$\square$ Waterbody

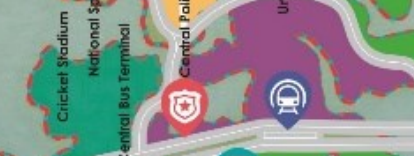

i)
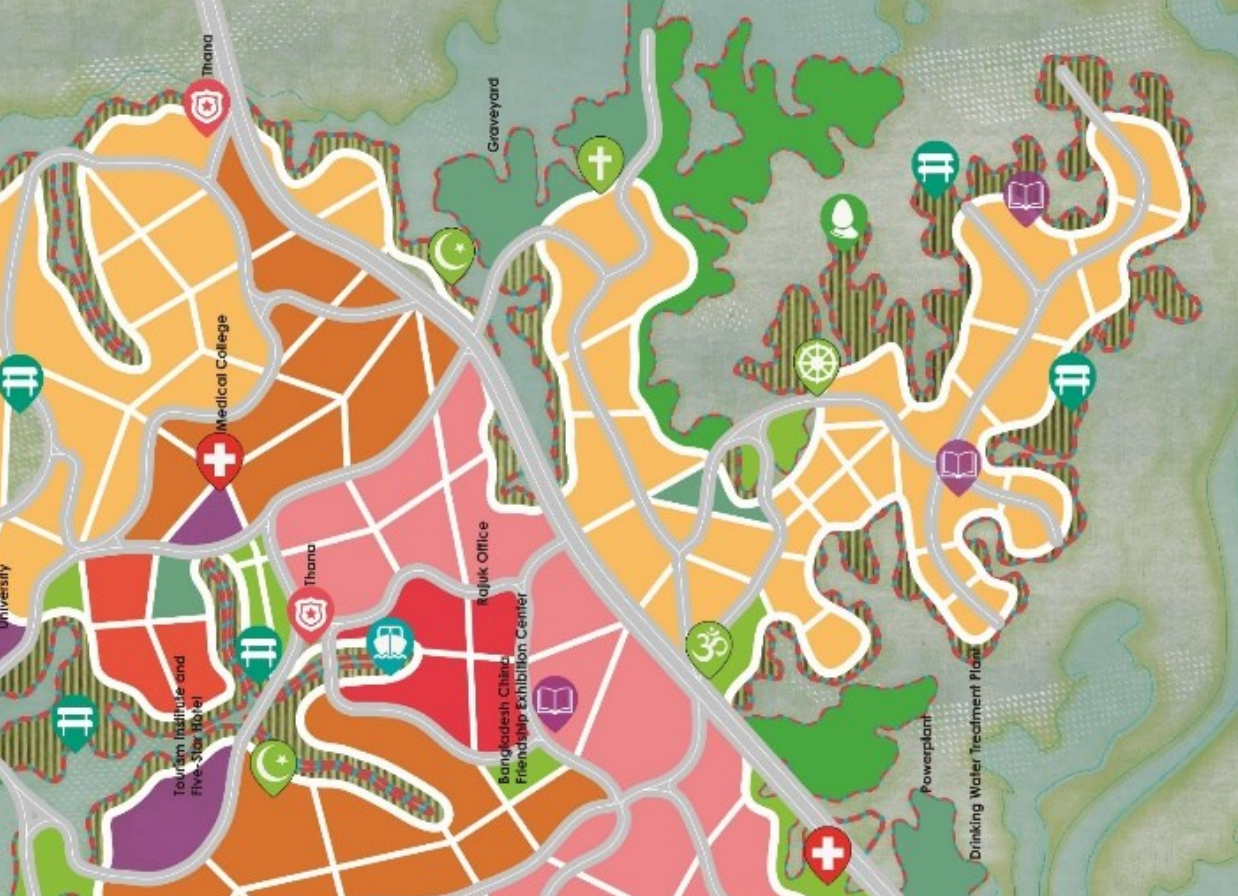

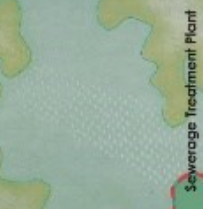
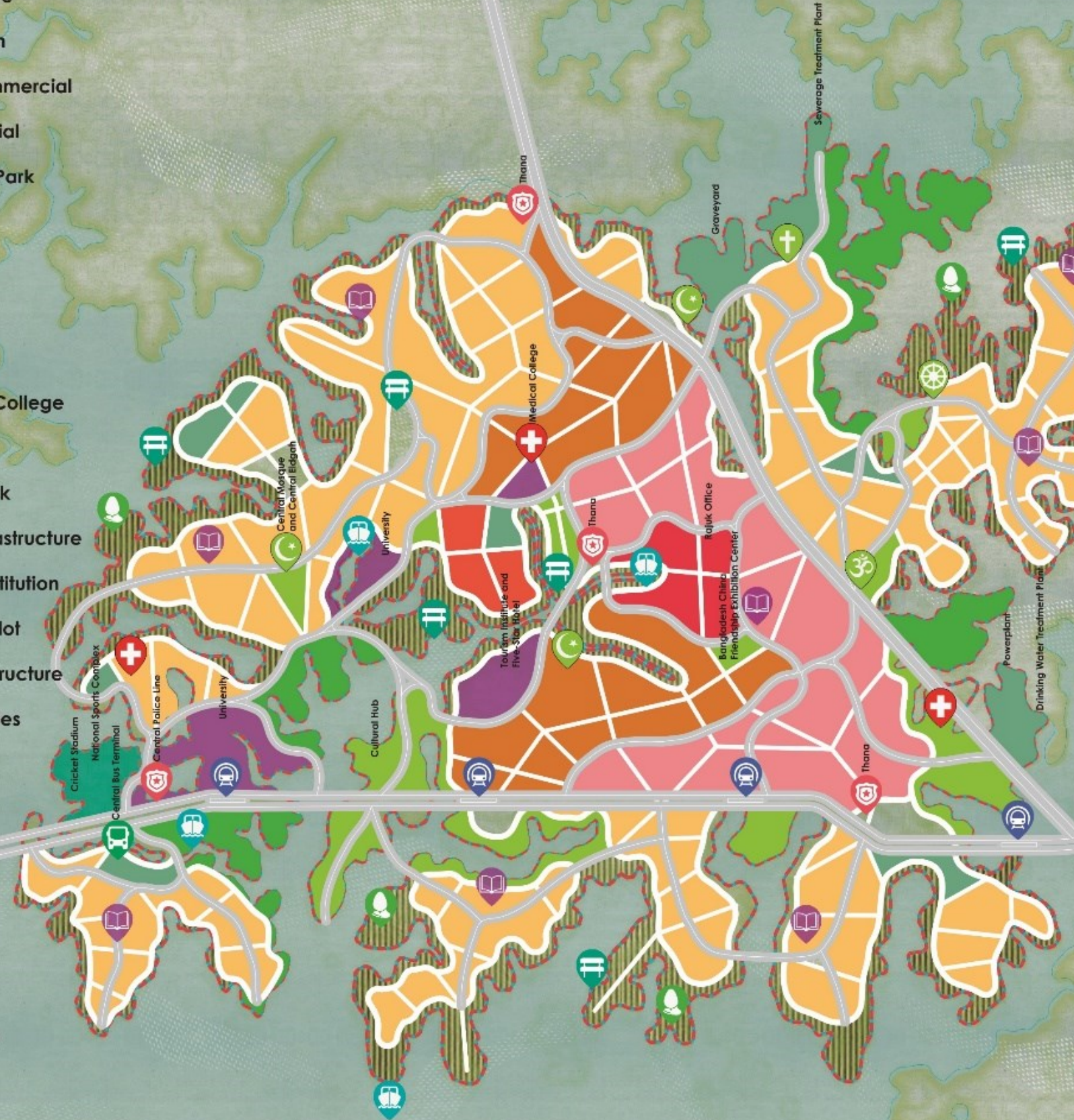

(2)

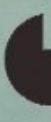

$0,5 \quad 1$

2

3

$4 \mathrm{~km}$

Figure 6.6: Proposed Masterplan 


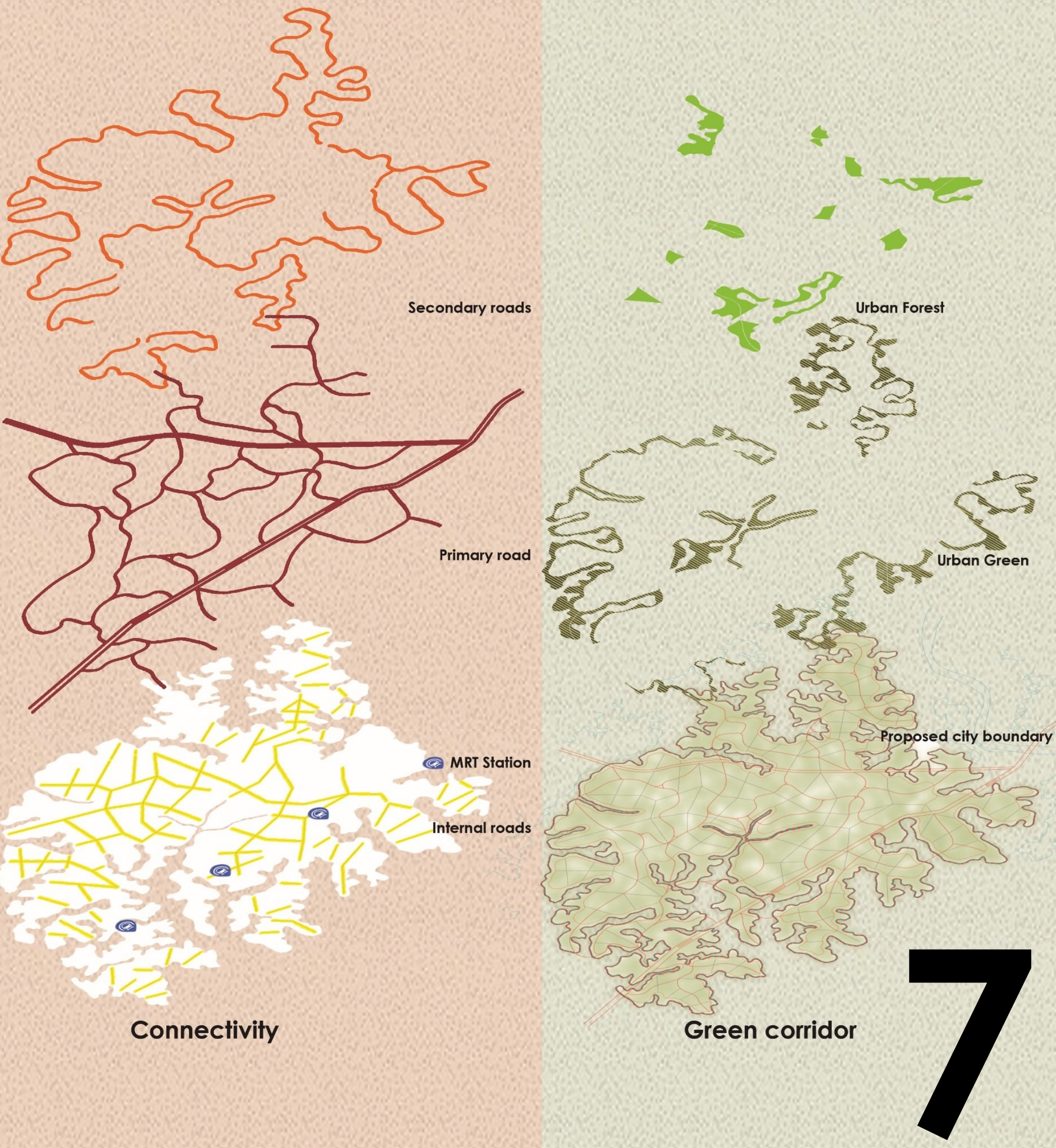




\title{
Chapter 7 Site Design and Details
}

\subsection{Detailed Site Plan}

\author{
Administrative \\ (0) Police Station \\ Mix Use Commercial \\ Mix Residential \\ F Community Park \\ (*) Mosque \\ (3) Temple \\ (t) Church \\ (4) Pagoda \\ (D) School and College \\ (3) Health \\ Industrial Park
}

$\square$ Physical Infrastructure

Research Institution

\section{$\square$ Residential Plot}

$\square$ Social Infrastructure

Sports Facilities

$\square$ Urban Forest

Pedestrian

@ MRT Station

(B) Ghat

8 Eco-park

$\square$ Roads

ㅍiIIII Urban Green

Waterbody
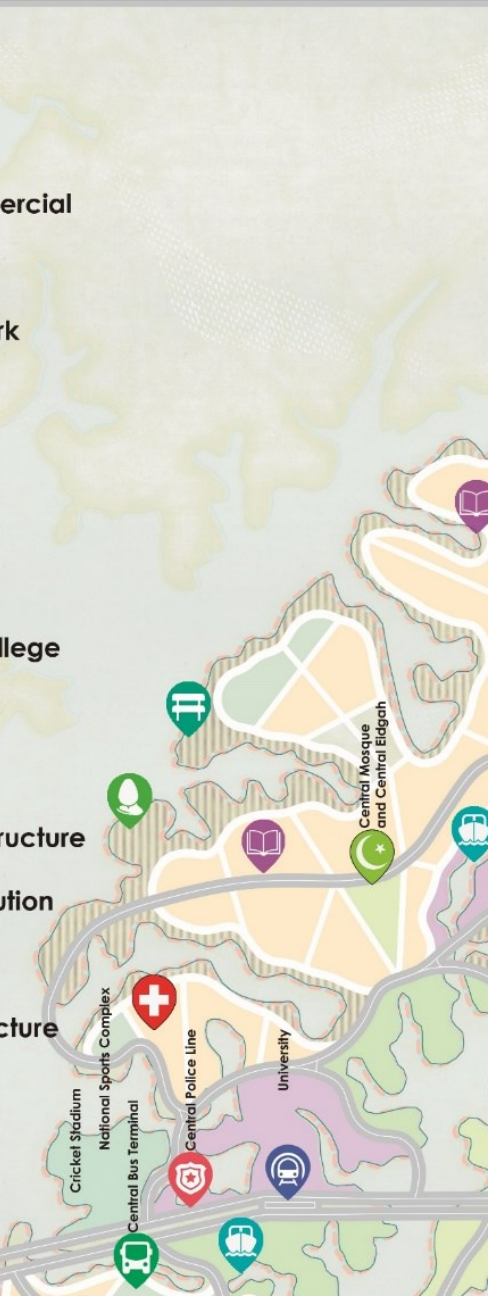


\subsection{Site 01: Commercial Zone}

The central part of Purbachal will be administrative, commercial and a hub for information technology sectors. The area will be the prototype for an efficient, modern, sustainable city hub for Bangladesh.

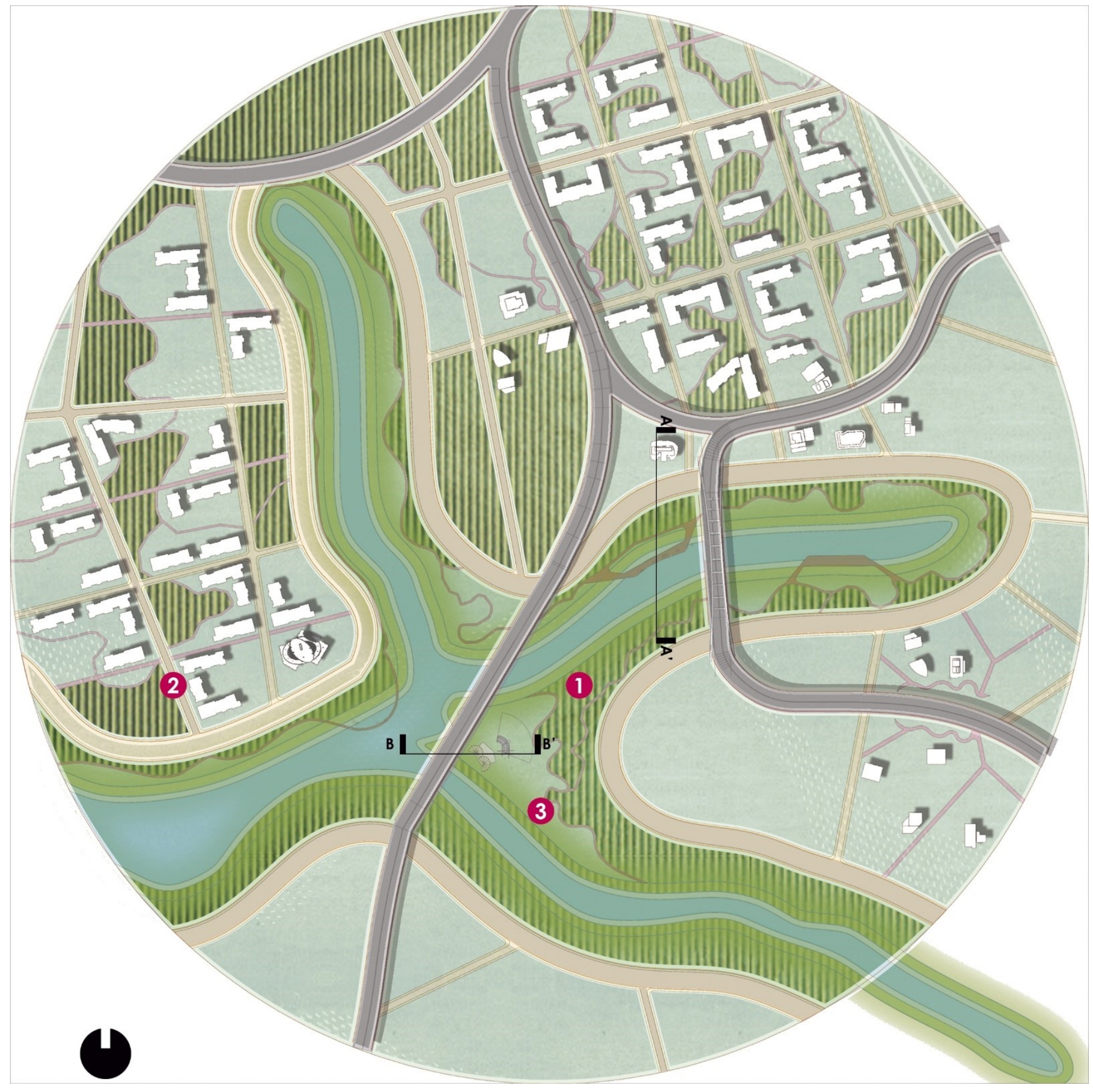

Figure 7.2: Site 01: Commercial Zone Plan 


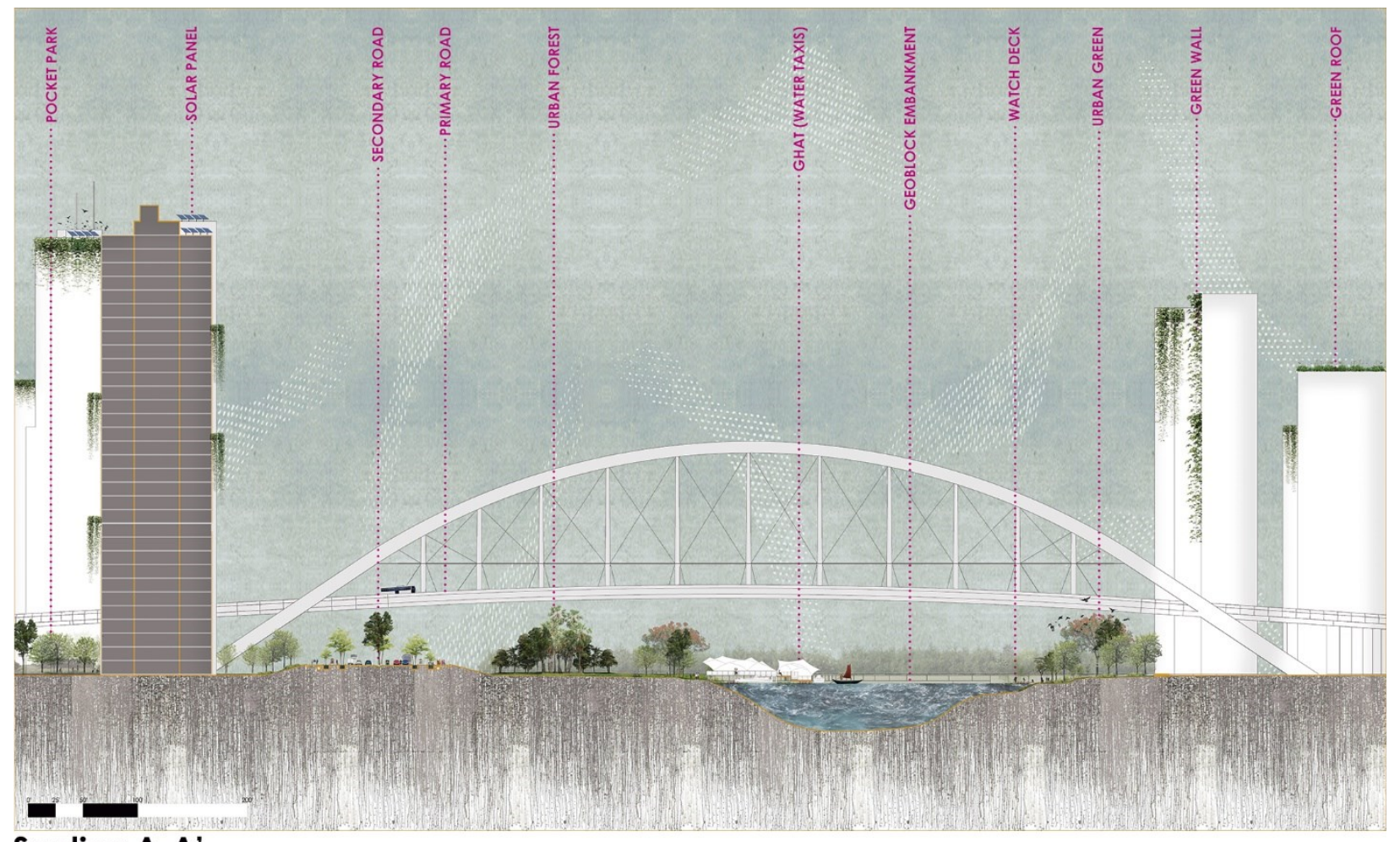

Section A-A'

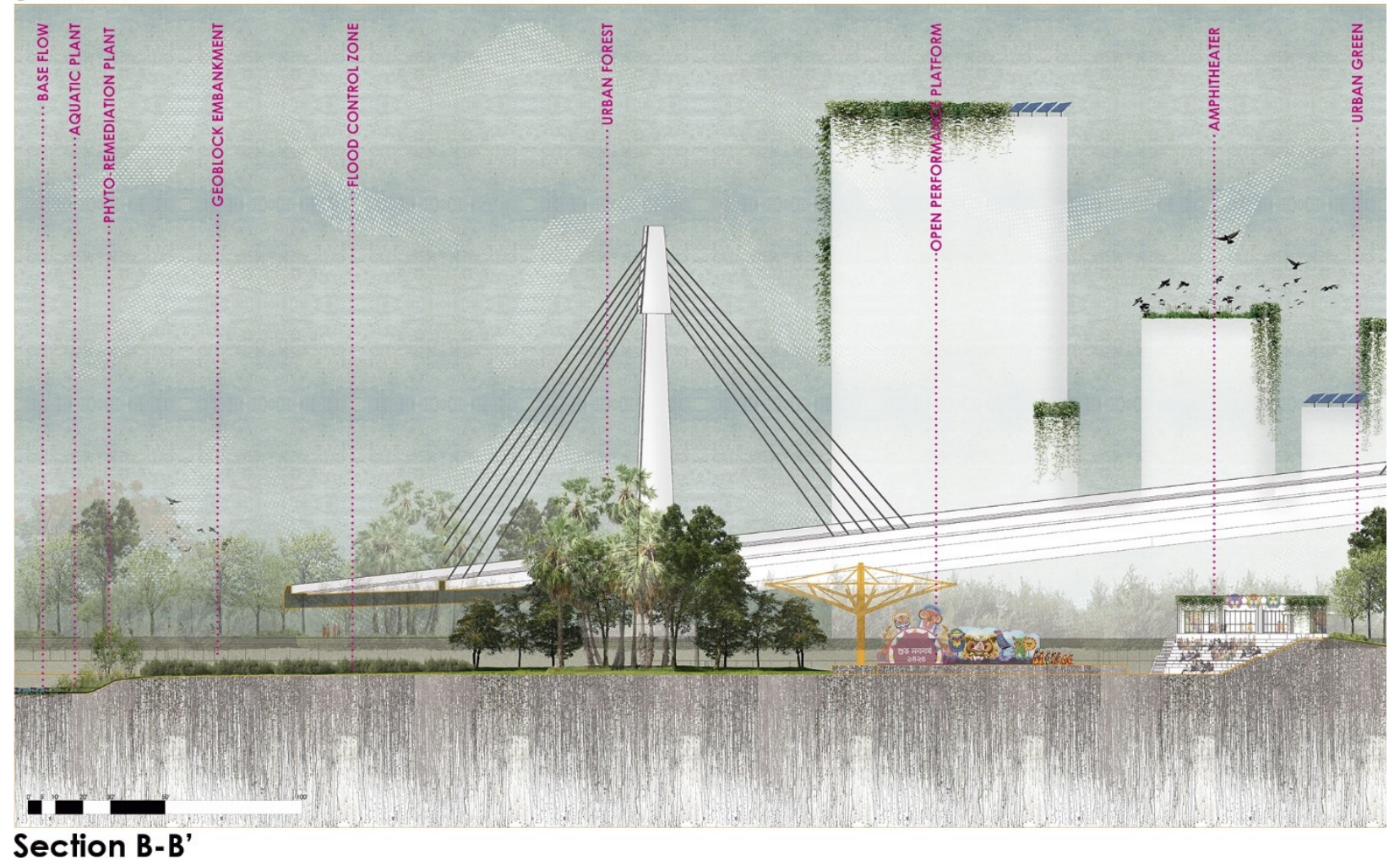

Figure 7.3: Site 01: Sections 
Instead of creating an automobile-oriented commercial district, the design proposes a walkable mixed-use zone. Vibrant street activities are one of the main characteristics of a Bangladeshi cities. To accommodate a wide range of outdoor activities, pocket parks are proposed within the buildings. The green spaces can act as an extension of the commercial activities like restaurants and offices to create a vibrant, connected urban places to work, live, play, and enjoy life.

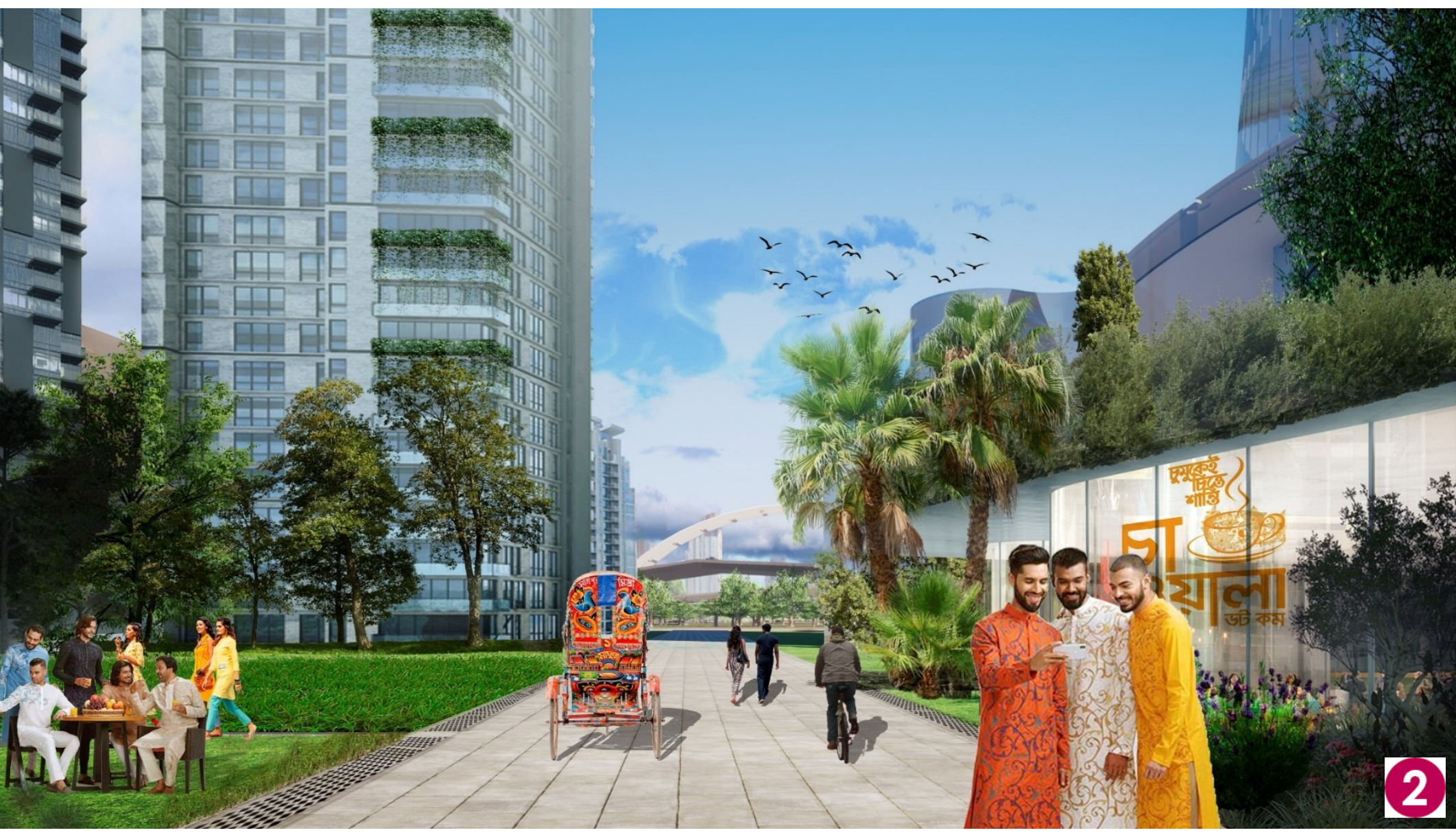

Figure 7.5: Characteristics of internal road layout

Bangladesh is a land of festivals. There is a popular saying in Bangla 'Baro Mashe Tero Paban' meaning 13 festivals in 12 months. The festivals observed by the people of Bangladesh are linked to religion, culture, seasons and specials occasions where people gather in large number to celebrate the event. The masterplan provides open performance platforms to create cultural hubs where people will be able to make processions and arrange cultural programs. The cultural hubs will act as a common ground for citizens with diverse religious and ethnic background to celebrate these festivals. 


\subsection{Site 02: MRT Station}

The design prioritized the use of public transportation by developing a transit-oriented system. People can access public bus service within 500 meters from any location.

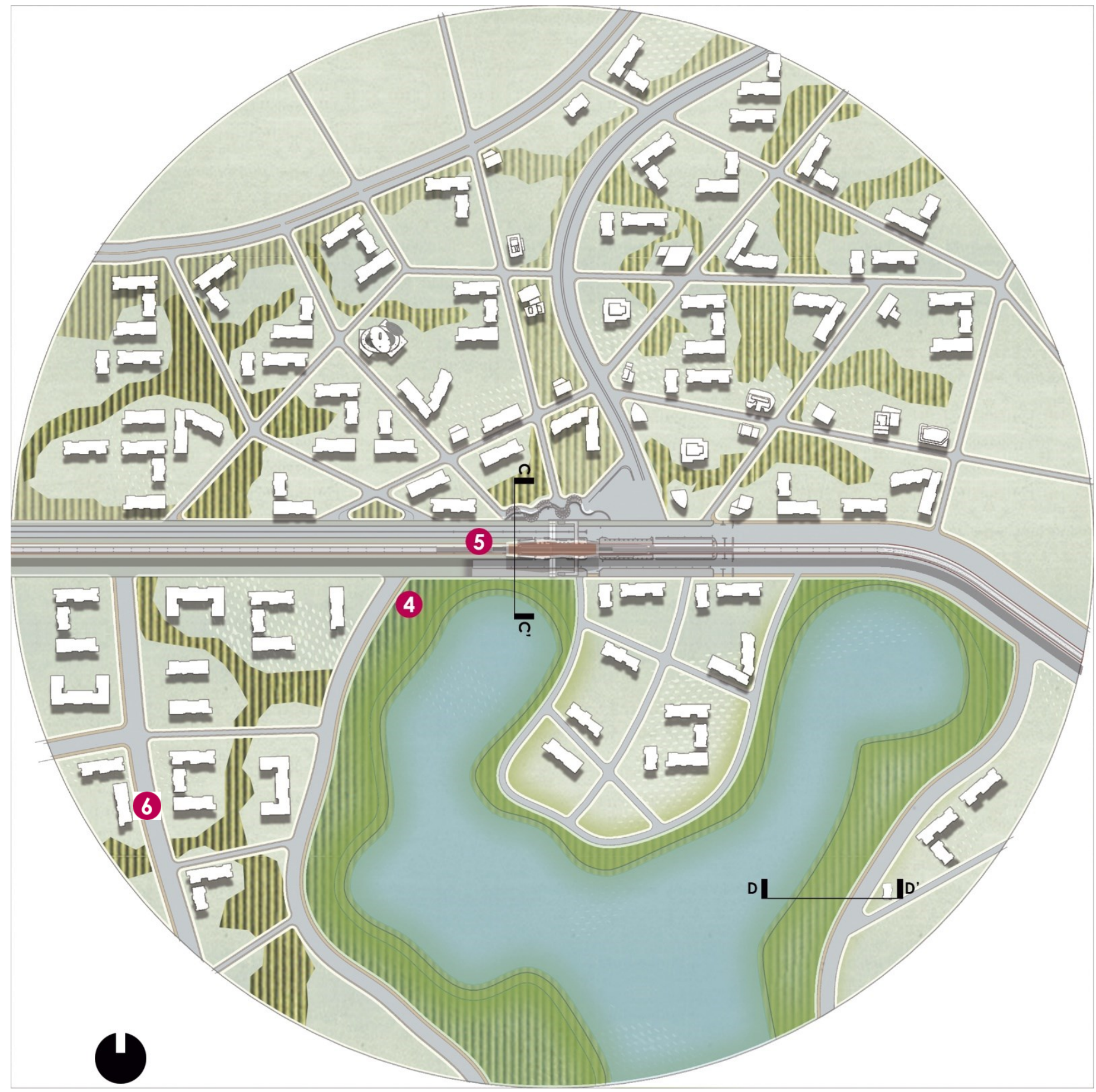

Figure 7 .7: Site 02: MRT Station Area Plan 


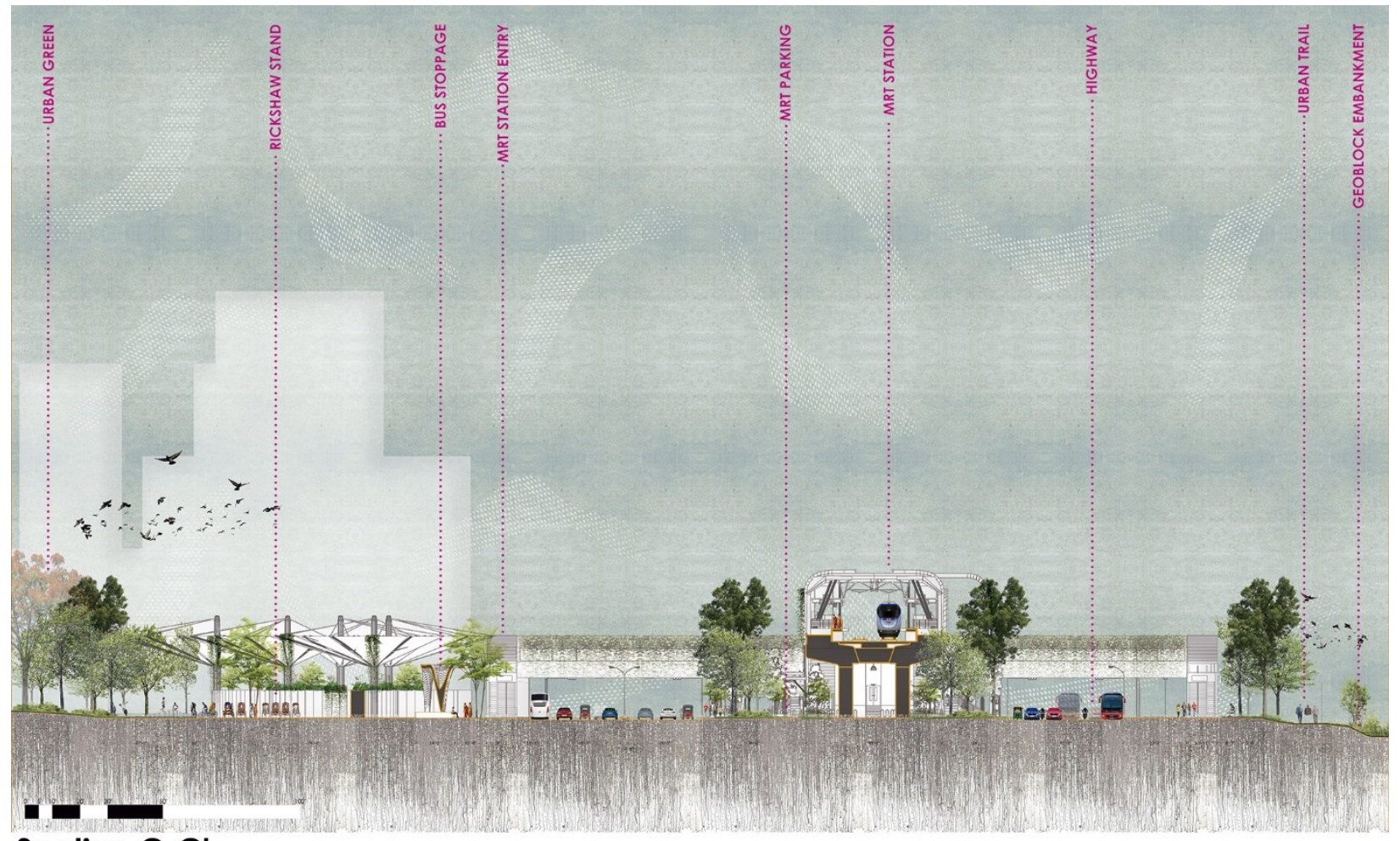

\section{Section C-C'}

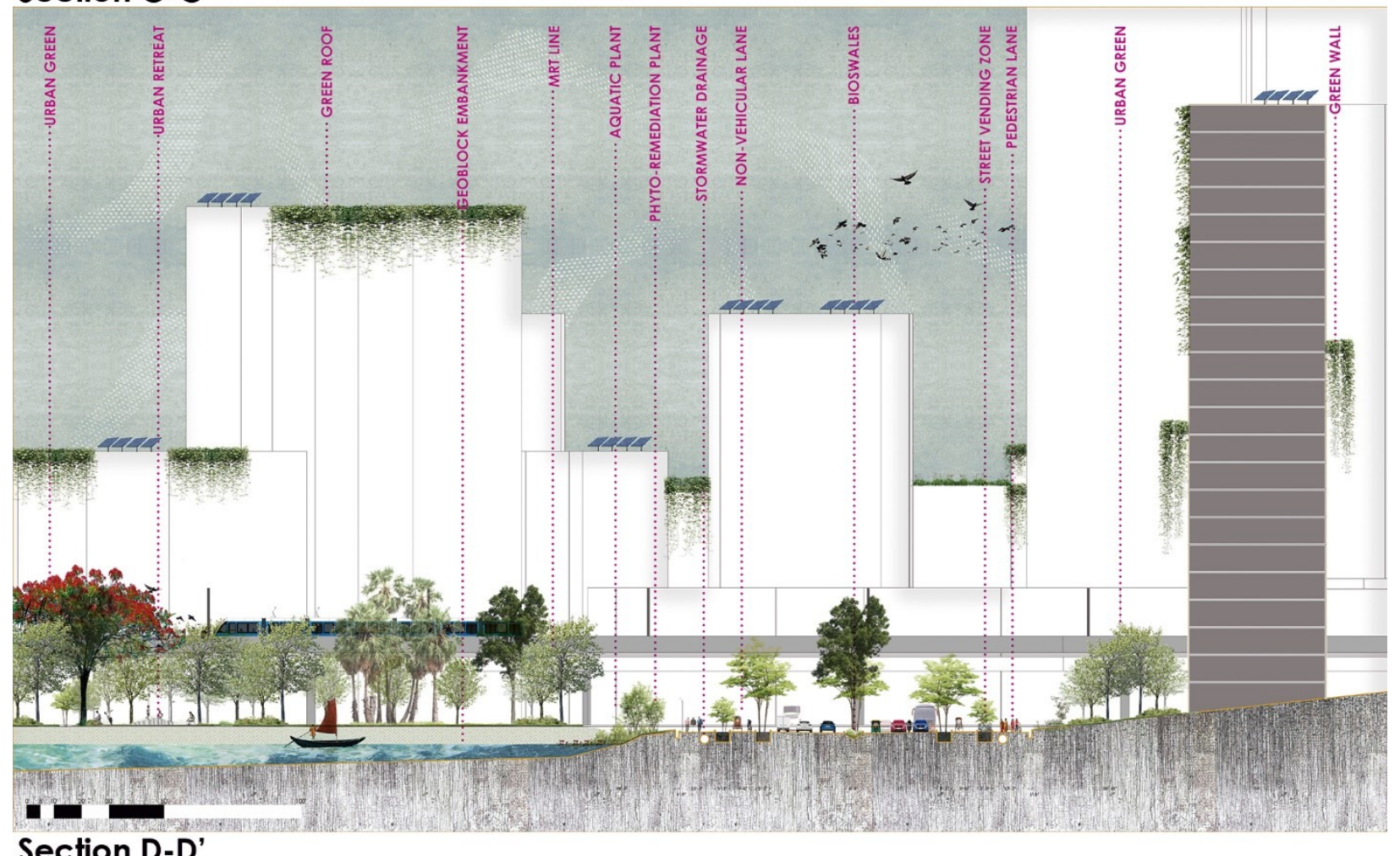

Figure 7.8: Site 02: Sections 
Mass Rapid Transit (MRT), with a combination of Bus Rapid Transit (BRT) is suggested to prioritize public transport. This will help to create a hierarchical framework for creating urban centers at different scales providing corresponding levels of services and employment opportunities to meet the local demand. The transit-oriented development approach will reduce the need for long-distance trips and help to tackle problems related to traffic congestion.

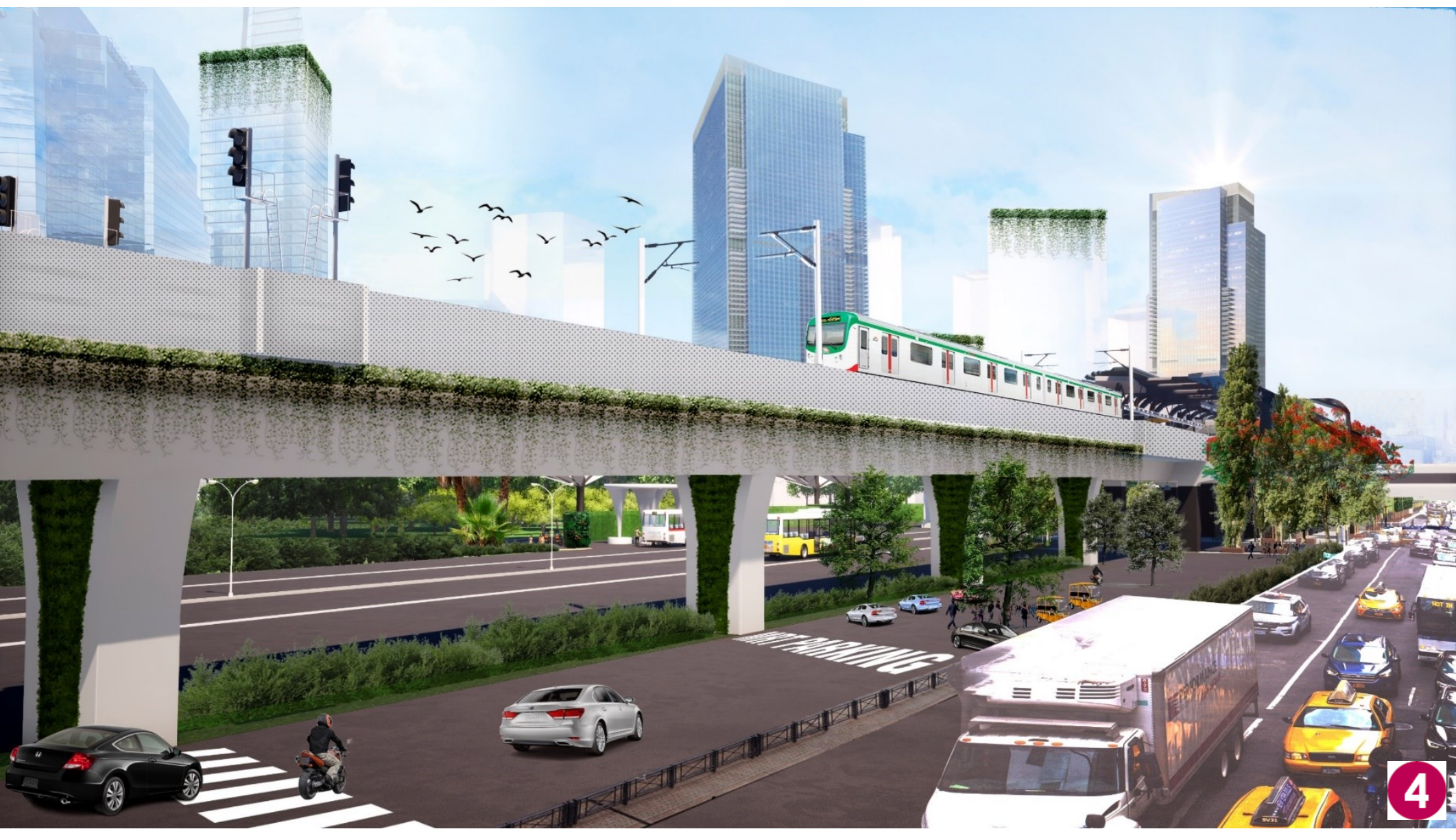

Figure 7.9: Different modes of transportation

The design has put emphasis on accessibility to public, commercial, and business facilities; and proposed high-quality pedestrian network around MRT stations. The MRT line 1 will develop an efficient, integrated, and modern transit system connecting the Purbachal new town with capital city Dhaka. The MRT stations therefore is treated as one of the most important areas for the urban fabric of the city. The design proposes an integrated system with the adjacent land use, landscaping and with other public transportation infrastructures to create a well-connected mass transportation network. The design provided designated parking areas for each station and located BRT stations adjacent to each MRT station. 
As many people in Bangladesh rely on non-motorized transportation like a rickshaw, each bus stop has a rickshaw stand and bicycle-sharing facility to make the city more environmentally friendly. By making the internal roads narrow with multiple angular intersections, high-speed vehicular transportation is discouraged in internal roads.

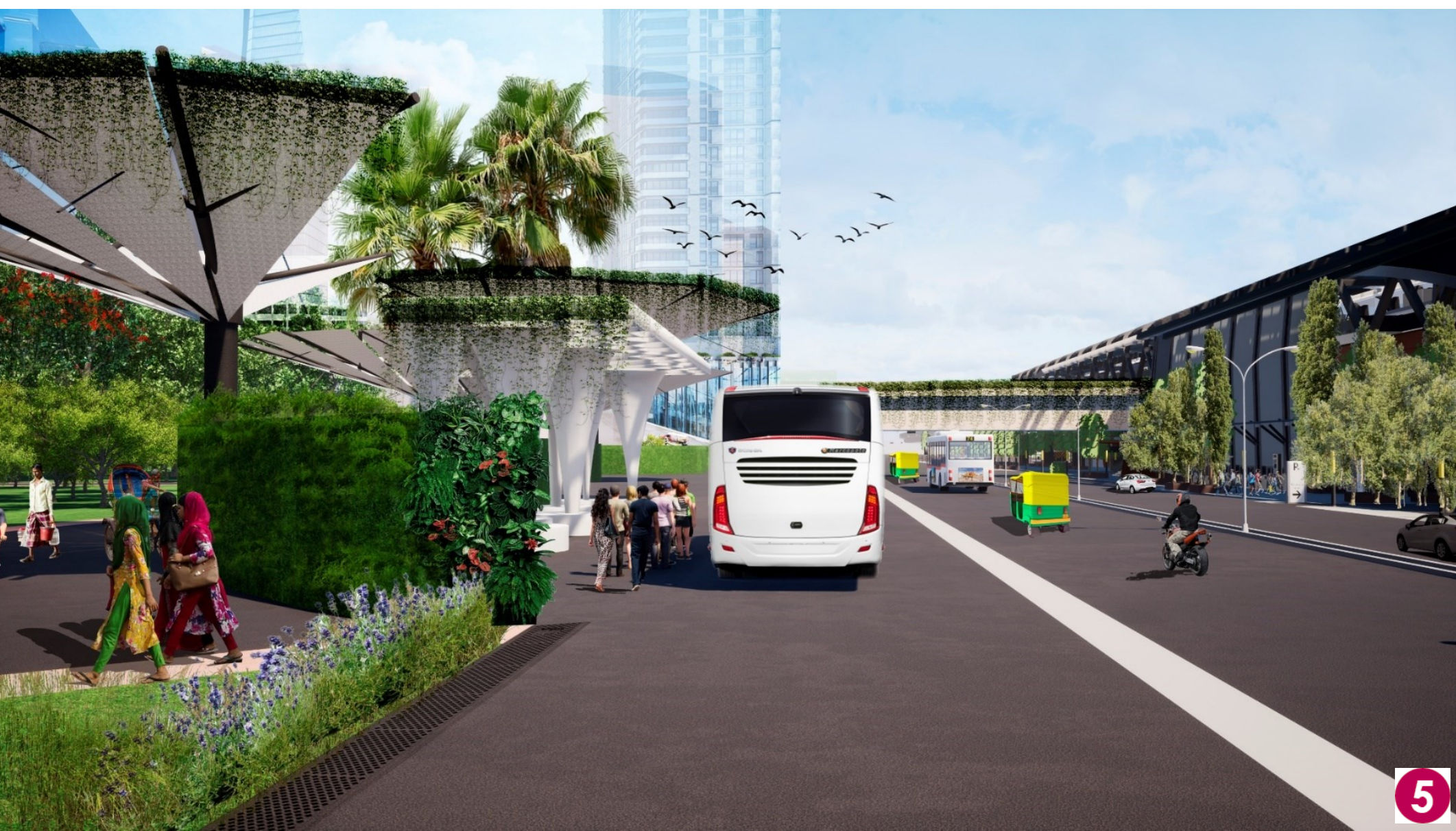

Figure 7.10: Different modes of transportation

By expanding public transit networks, people are encouraged to use public transportation rather than driving. The design also proposes small-scale urban farming to reduce the dependency on large-scale food production. The urban farming will create new activities within the community and generate working spaces in the green strip. 
The primary roads will have 3 major sections. There are non-vehicular lanes on both sides with provisions for street vendors. Adjacent to this This non-vehicular lane, there is nonmotorized lane used by rickshaw and bicycles. For motorized vehicles, there is 3 vehicular lanes on both sides. To reduce auto-traffic congestion and maintain frequent, on-time service, Bus Rapid Transit lane (BRT) is proposed.

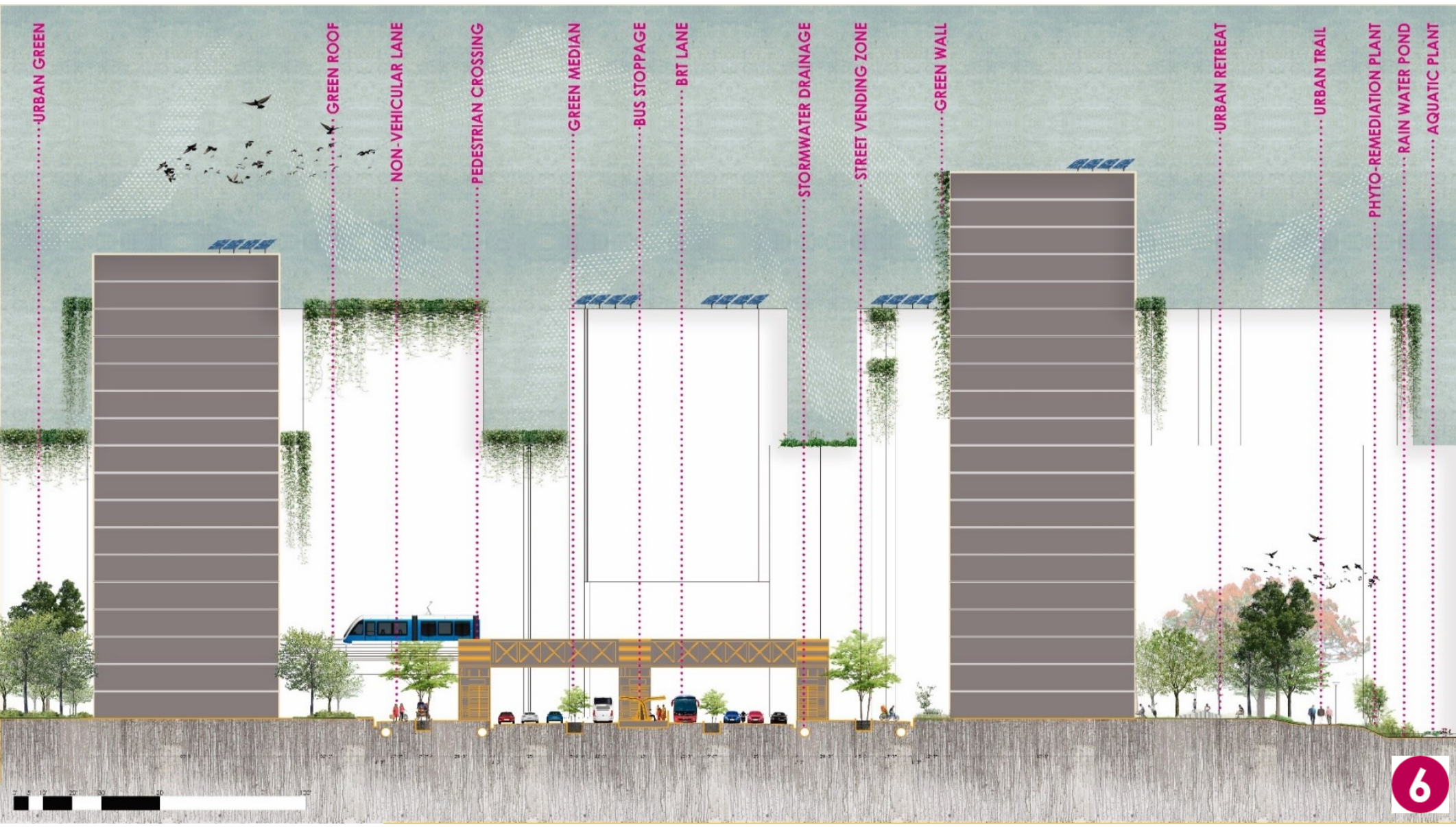

Figure 7.1 1: Primary Road detail

The dedicated travel lane at center is only accessible to BRT vehicles to ensures buses can move quickly without being impacted by other traffic incidents. A pedestrian crossing will connect the BRT bus stoppage with non-vehicular lanes on both sides of the road.

The wind speed on the ground level gets increased due to the wind turbulence created by the adjacent Highrise building (Datta 2017). The urban green elements will help to reduce the wind speed at the base of Highrise buildings to create a comfortable walking condition. 


\subsection{Site 03: Residential Zone}

The residential areas are designed to be pedestrian friendly. Non-motorized vehicles are prioritized. Green buffers separate the pedestrian walkways from vehicular traffic while maximizing urban green space.

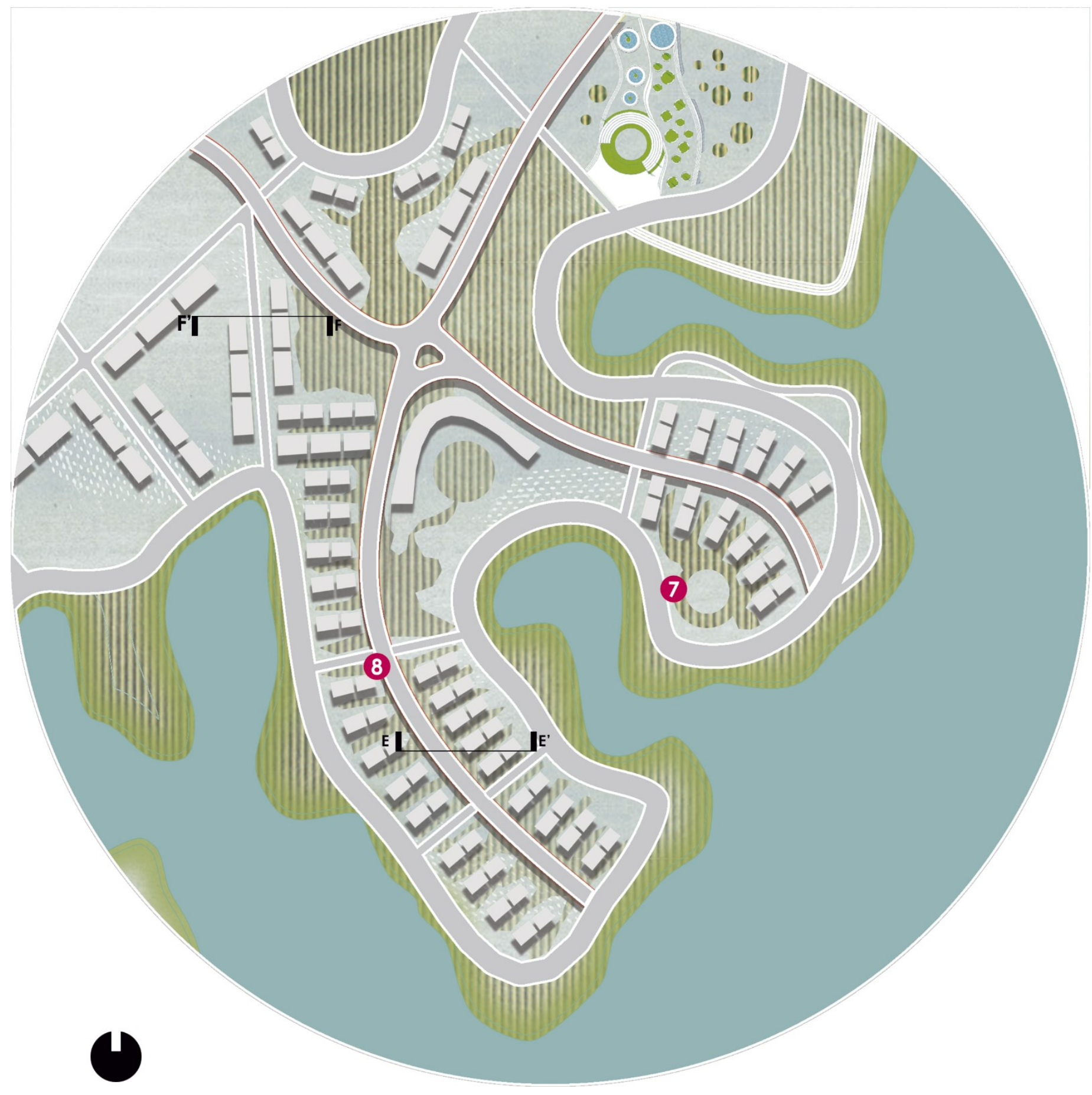

Figure 7 .12: Site 03: Residential Zone Plan 


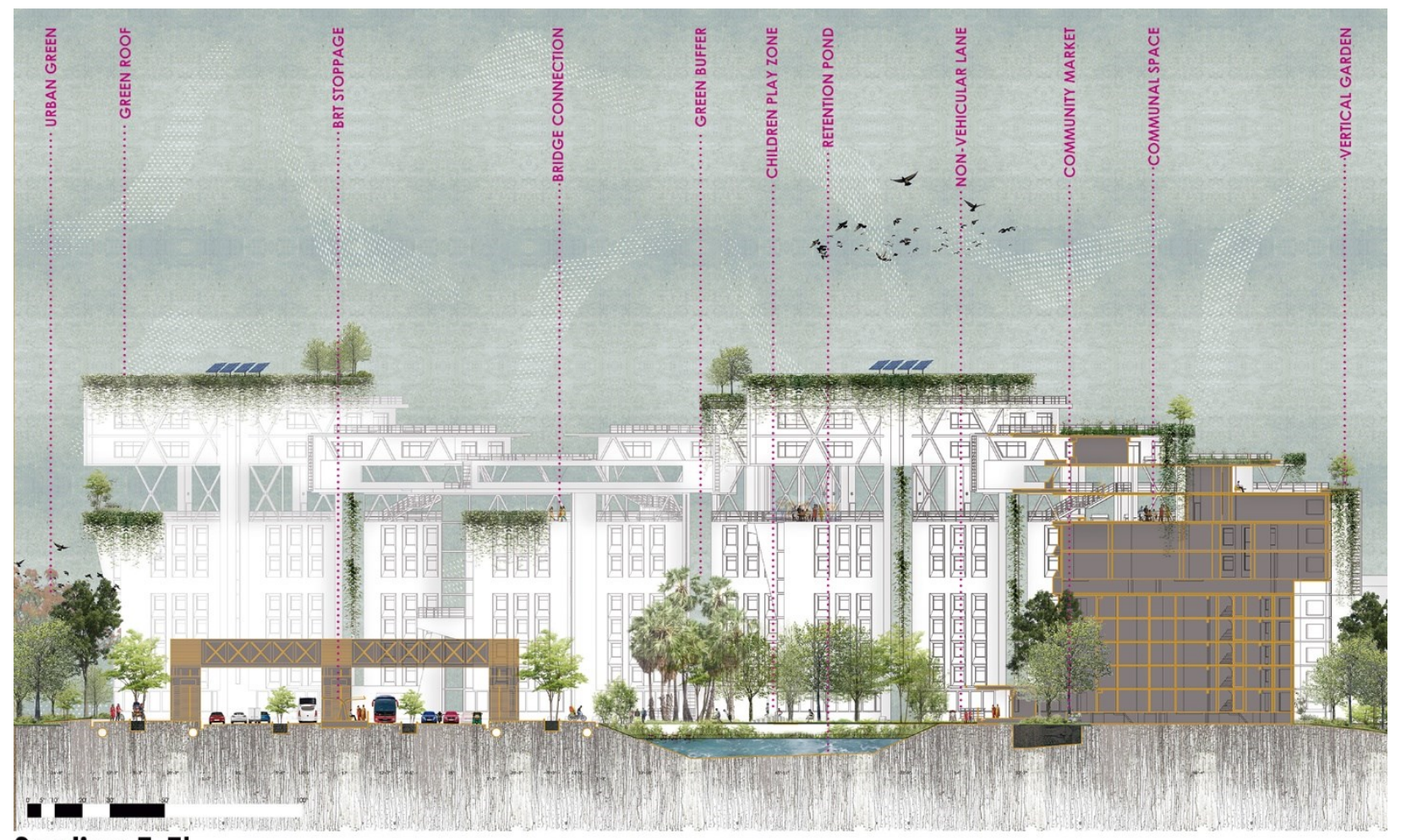

\section{Section E-E'}

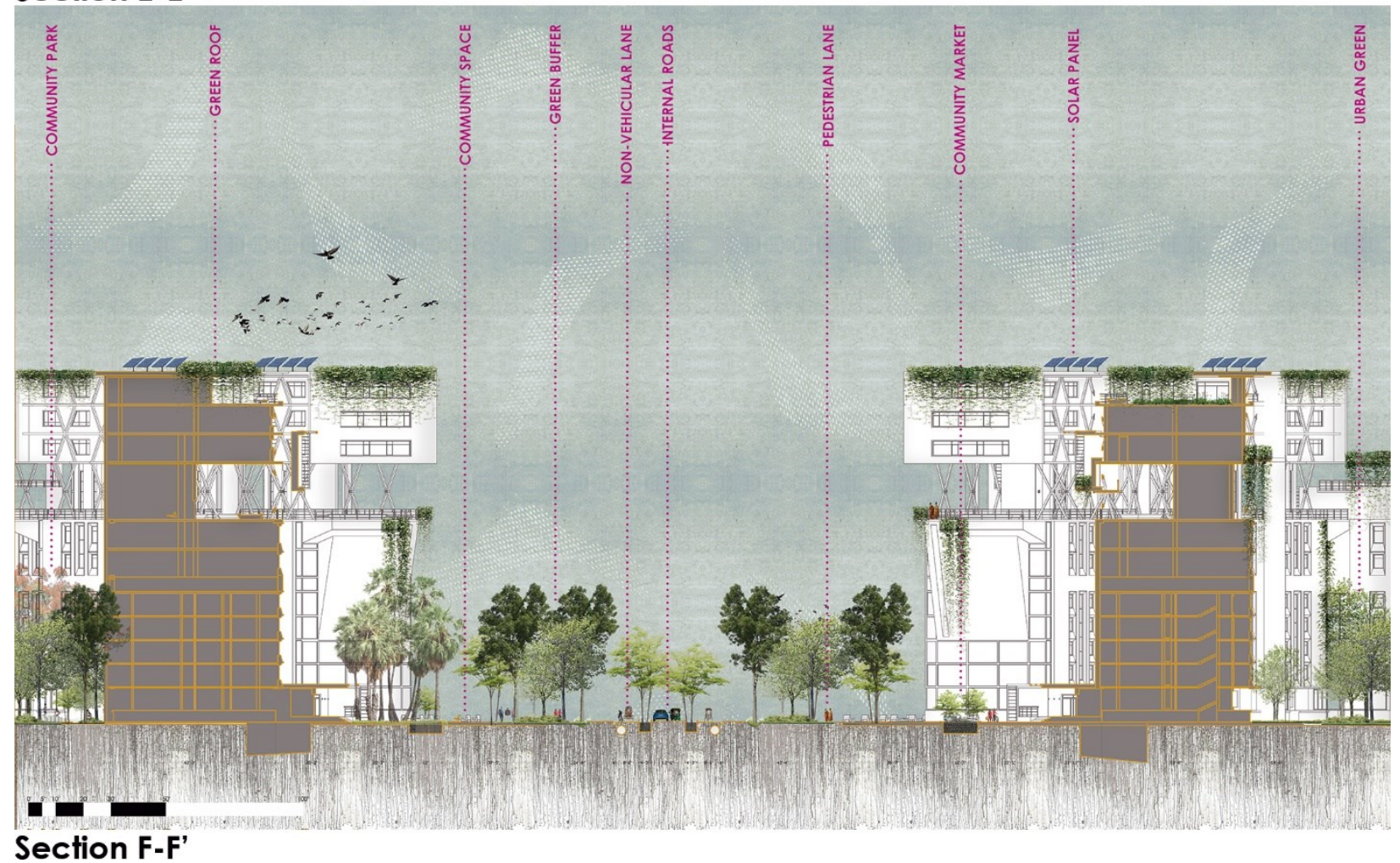

Figure 7.13: Site 03: Sections 
Two layers of natural buffers act as a barrier to reduce noise pollution from the arterial roads. Green buffers with urban greenery will help to reduce noise level and absorb air pollution. These green buffers will include children play zones that will provide a natural pay environment for the community. Each neighborhood complex will include water retention ponds to store rain water which will reduce the amount of water runoffs during heavy rains. Reducing runoff will help to prevent water pollution, reduce urban flooding, and protect the natural ecosystem by preserving alluvial top soil. The retention ponds will also play vital role to maintain water table by replenishing the underground water.

Street activities play an important role in everyday life of a city dweller in Bangladesh. Streets often act as a space for social interaction, leisure events and commercial activities. To accommodate these events, the internal roads within the residential areas will have multiple layers of non-vehicular and pedestrian lane. The narrow vehicular lane will be minimizing motorized traffic. Community space with provisions for group sitting, board games and shaded areas are provided to enhance interactions between community members. Each neighborhood complex will have a designated community market to server the neighborhood.

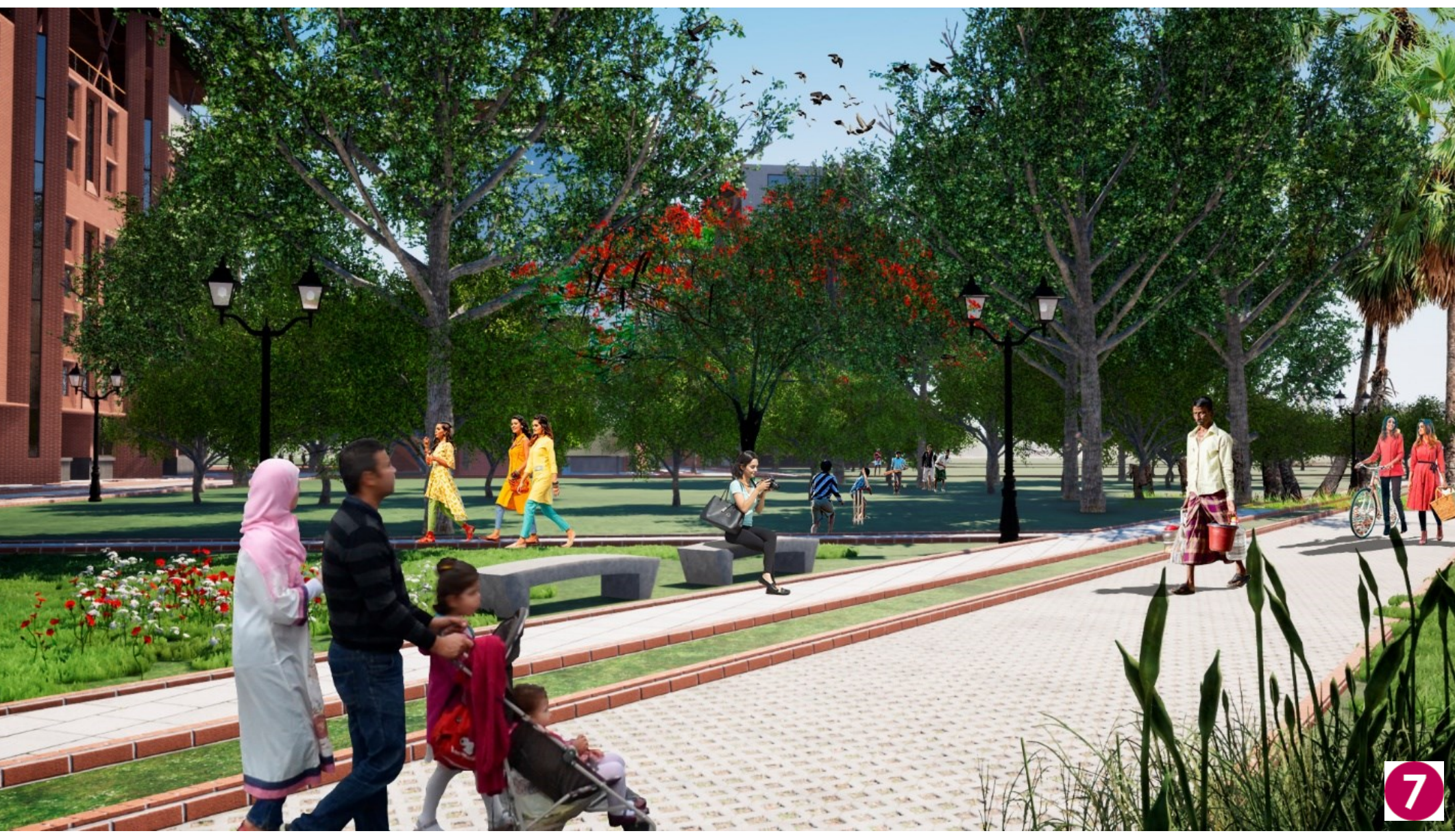

Figure 7.14: Greenery intertwined with the residential zone 
The cities now a days face rapidly evolving challenges that put immense pressures on the urban dwellers. By creating a living condition connected to natural elements can reduce the mental and stress and enhance a sense of well-being. The design promotes Biophilic urbanism concepts by integrating natural elements and processes into the built environment to meet people's inherent need for contact with nature.

The design proposes neighborhood parks located within 200 meters of every residential apartment blocks. Each park will have bicycle path, urban trails and open space for children to play. A wide range of indigenous plants at different level will create an ecologically balanced environment fostering a wide variety of habitats. These urban parks will act as a natural sanctuary for indigenous birds and animals. The ever-changing colors from the plants, fragrant of flowers and chippering of birds will create a soothing, calm and harmonious living environment.

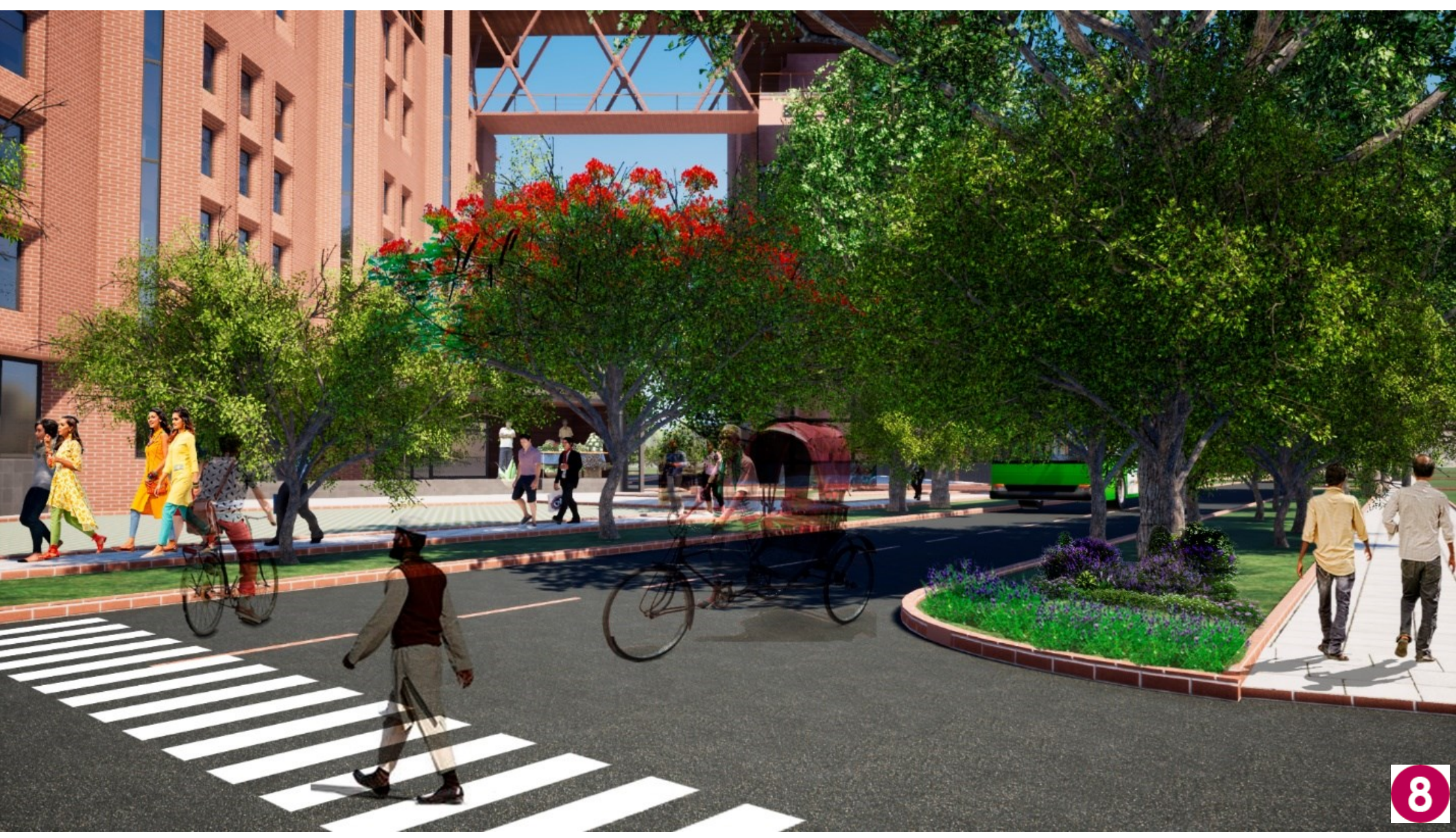

Figure 7.15: High-speed vehicular transportation is discouraged in internal roads 


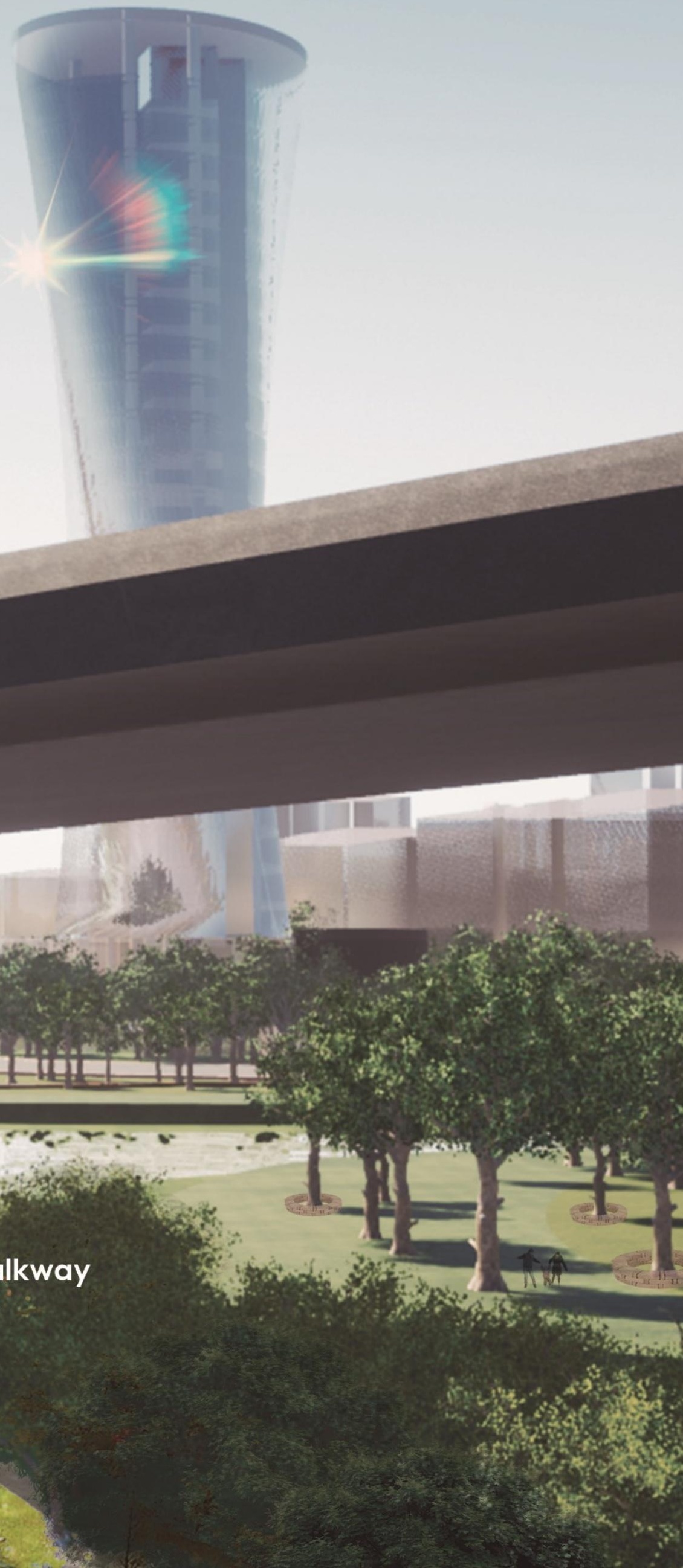




\section{Chapter 8 Conclusion}

The design promotes connections with natural elements to create a biophilic city. Water has been an intricate part of the life of the people of Bangladesh. The plan proposes to incorporate greenery intertwined with the vast networks of the waterway and make them accessible for recreational purposes. The wetland will support an incredible range of flora and fauna and create a natural habitat for local species.

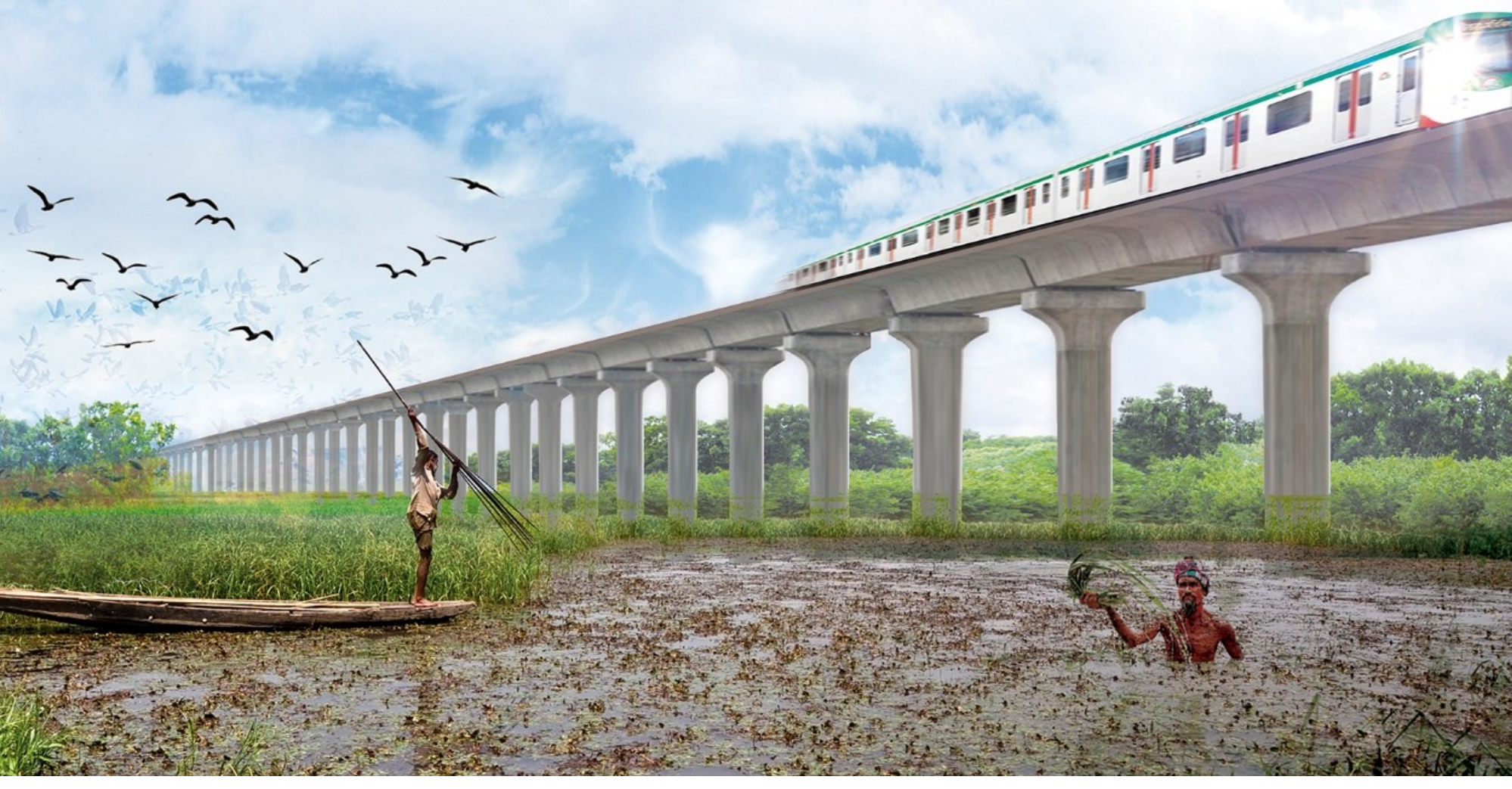

Figure: 8.1: Development with natural harmony

The low-lying areas around the city plays a crucial role to protect Dhaka from major flooding. The surrounding wetlands of Purbachal support a wide range of agricultural activities, fish cultivation. A variety of natural vegetation in this area has created a unique ecosystem. The wetlands have a soil structure that is distinctive from that of surrounding uplands. The design protects these wetlands and enhances the natural ecosystem by promoting plantation of indigenous plants. The vast stretch of wetland will be seen while entering the city from the surrounding areas, giving the city a unique identity. 
The design prioritized the use of public transportation by developing a transit-oriented system. People can access public bus service within 500 meters from any location. As many people in Bangladesh rely on non-motorized transportation like a rickshaw, each bus stop has a rickshaw stand and bicycle-sharing facility to make the city more environmentally friendly. By making the internal roads narrow with multiple angular intersections, high-speed vehicular transportation is discouraged in internal roads. By expanding public transit networks, people are encouraged to use public transportation rather than driving. The design also proposes small-scale urban farming to reduce the dependency on large-scale food production. The urban farming will create new activities within the community and generate working spaces in the green strip.

To summarize, the project explores the complex interrelation of different natural factors responsible for protecting the city from adverse natural calamities. By analyzing the geohydrological aspects, a realistic city planning process suited for the context of Bangladesh is formulated. The resilient new plan of Purbachal synthesizes Geodesign with the concept of Biophilia to create a city where people will live in harmony with nature and provide a framework for the future resilient cities in the region.
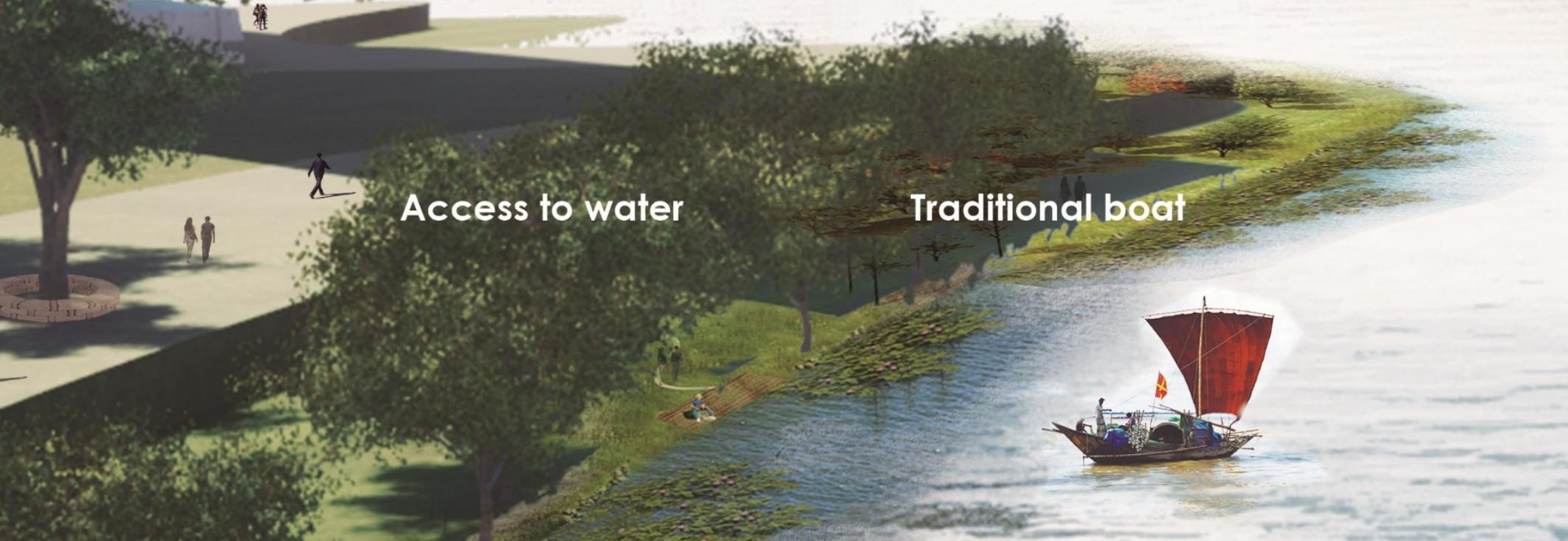


\section{References}

Ahmed, B., \& Ahmed, R. (2012). Modeling urban land cover growth dynamics using multi temporal satellite images: a case study of Dhaka, Bangladesh. ISPRS International Journal of Geo-Information, 1 (1), 3-31.

Ahmed, B., Kamruzzaman, M., Zhu, X., Rahman, M., \& Choi, K. (2013). Simulating land cover changes and their impacts on land surface temperature in Dhaka, Bangladesh. Remote Sensing, 5(1 1), 5969-5998.

Ahmed, B., Hasan, R., \& Maniruzzaman, K. M. (2014). Urban morphological change analysis of Dhaka city, Bangladesh, using space syntax. ISPRS International Journal of Geo-Information, 3(4), 1412-1444.

Ahammed, F., Hewa, G. A., \& Argue, J. R. (2014). Variability of annual daily maximum rainfall of Dhaka, Bangladesh. Atmospheric research, 137, 176-182.

Ahsan, R. M. (1991). Changing pattern of the commercial area of Dhaka city. Dhaka Past Present and Future. Dhaka: The Asiatic Society of Bangladesh, 396-414.

Al-Hagla, K. (2008). Towards a sustainable neighborhood: The role of open spaces. Architectural Research, 2, 162-177.

Ali, A. M., Solomatine, D. P., \& Di Baldassarre, G. (2015). Assessing the impact of different sources of topographic data on 1-D hydraulic modelling of floods. Hydrology and Earth System Sciences, 19(1), 631-643.

Ali, A. (1996). Vulnerability of Bangladesh to climate change and sea level rise through tropical cyclones and storm surges. In Climate change vulnerability and adaptation in Asia and the Pacific (pp. 171-179). Springer, Dordrecht.

Bangladesh Bureau of Statistics (BBS) (2019) Statistical yearbook of Bangladesh. Ministry of Planning, Dhaka.

Batty, M. (2007). Cities and complexity: understanding cities with cellular automata, agent-based models, and fractals. The MIT press.

Barnett, J. (2016). City design: Modernist, traditional, green and systems perspectives. Routledge.

Baran, P. (1964). On distributed communications networks. IEEE transactions on Communications Systems, 12(1), 1-9.

Berke, P. R., MacDonald, J., White, N., Holmes, M., Line, D., Oury, K., \& Ryznar, R. (2003). Greening development to protect watersheds: does new urbanism make a difference? Journal of the American Planning Association, 69(4), 397-413.

Bird, J., Li, Y., Rahman, H. Z., Rama, M., \& Venables, A. J. (2018). Toward great Dhaka: A new urban development paradigm eastward. Chapter-3: East and West. The World Bank. 
Calthorpe, P. (2010). Urbanism in the age of climate change. Island Press.

Cervero, R. (1998). The transit metropolis: a global inquiry. Island press.

Churchman, A. (1999). Disentangling the concept of density. Journal of planning literature, 13(4), 389-411.

Cohen, J. E. (2003). Human population: the next half century. science, 302(5648), $1172-$ 1175.

Datta, U., \& Mandal, D. (2017). Creating blue network: A solution of present water logging and transportation problem for the Dhaka metropolitan area. Design that cares-inter disciplinary approach to making built environments efficient and meaningful.

Datta, U. (2017). Evaluating the impact of Highrise buildings on adjacent urban wind environment: a case study on Gulshan area.

Dewan, A. M., \& Yamaguchi, Y. (2009). Using remote sensing and GIS to detect and monitor land use and land cover change in Dhaka Metropolitan of Bangladesh during 1960-2005. Environmental monitoring and assessment, 150(1-4), 237.

Dewan, A. M., \& Yamaguchi, Y. (2009). Land use and land cover change in Greater Dhaka, Bangladesh: Using remote sensing to promote sustainable urbanization. Applied geography, 29(3), 390-401.

Dewan, A. M., Islam, M. M., Kumamoto, T., \& Nishigaki, M. (2007). Evaluating flood hazard for land-use planning in Greater Dhaka of Bangladesh using remote sensing and GIS techniques. Water resources management, 21(9), 1601-1612.

Douglas, F. (2008). Sustainable urbanism: urban design with nature. Hoboken, NJ Wiley.

Duvigneaud, Paul, and Simone Denaeyer-De Smet. L'ecosystème urbain bruxellois. 1977.

Economically strong and sustainable Structural Vision: Amsterdam 2040, published by the Department of Physical Planning (Dienst Ruimtelijke Ordening, or DRO), March 2011

Félix, G., Ian, P., \& Paul, S. (2000). The three ecologies. London: Athlone.

Hess, D., \& Tasa, D. (2011). McKnight's physical geography: a landscape appreciation. Upper Saddle River, NJ: Prentice Hall.

IBI Group 1990. The Implications of Long-term Climatic Changes on Transportation in Canada, Climate Change Digest, CCD90-02. Environment Canada, Downsview.

Isunju, J. B., \& Kemp, J. (2016). Spatiotemporal analysis of encroachment on wetlands: a case of Nakivubo wetland in Kampala, Uganda. Environmental monitoring and assessment, 188(4), 203.

Jacobs, J. (1961). The death and life of great American cities. Vintage.

Jensen, J. R. (2016). Introductory digital image processing: a remote sensing perspective (No. Ed. 4). 
Kasprisin, R. (2019). Urban design: the composition of complexity. Routledge.

Kadhim, N., Mourshed, M., \& Bray, M. (2016). Advances in remote sensing applications for urban sustainability. Euro-Mediterranean Journal for Environmental Integration, 1 (1), 7.

Kellert, S. R. (2008). Dimensions, elements, and attributes of biophilic design. Biophilic design: the theory, science, and practice of bringing buildings to life, 3-19.

Knowles, R. D. (2012). Transit oriented development in Copenhagen, Denmark: from the finger plan to Ørestad. Journal of transport geography, 22, 251-261.

Khan, N. I. (2000). Temporal mapping and spatial analysis of land transformation due to urbanization and its impact on surface water system: A case from Dhaka metropolitan area, Bangladesh. International Archives of Photogrammetry and Remote Sensing, XXXIII, Part $B, 7,598-605$.

Maternoski, J. M. (2013). Urban Growth in Copenhagen: Addressing Challenges Through Regional Urban Design.

Miller, E. J., \& Shalaby, A. S. (2000). Travel in the Greater Toronto Area: Past and Current Behaviour and Relation to Urban Form. Joint Program in Transportation, University of Toronto.

Mostafavi, M., \& Doherty, G. (Eds.). (2016). Ecological urbanism. Lars Müller Publishers.

Mowla, Q. A. (2008). Eco-Sustainability of Urban Environment-the Case of

Dhaka. International Continuing Education Meet on Sustainable Communities-Bridging the Gap between Research and Action, jointly organized by TKK-Finland, AlT-Thailand, UN-HABITAT and UNEP, 11-22.

Mowla, Q. A. (2012). Dhaka: a mega city of persistence and change. Urbanization in South Asia-focus on mega cities. Cambridge University Press, New Delhi.

Newman, P., \& Kenworthy, J. (1999). Sustainability and cities: overcoming automobile dependence. Island press.

Peter King (2014), Sustainable City Singapore. Retrieved from https://www.greengrowthknowledge.org/case-studies/sustainable-city-singapore

Qin, C., Zhu, A. X., Pei, T., Li, B., Zhou, C., \& Yang, L. 2007. "An adaptive approach to selecting a flow partition exponent for a multiple flow direction algorithm." International Journal of Geographical Information Science 21 (4): 443-458.

Sayuti, N. A. A., Hoyos, C. M., \& Bonollo, E. (2015). A study of furniture design incorporating living organisms with particular reference to biophilic and emotional design criteria. Academic Journal of Science, 4(1), 75-106.

Sørensen, E., \& Torfing, J. (2019). The Copenhagen metropolitan'fingerplan': A robust urban planning success based on collaborative governance. In Great Policy Successes (pp. 218-243). Oxford University Press. 
Shao, Z., Fu, H., Li, D., Altan, O., \& Cheng, T. (2019). Remote sensing monitoring of multiscale watersheds impermeability for urban hydrological evaluation. Remote Sensing of Environment, 232, 111338.

Sultana, M. S., Islam, G. T., \& Islam, Z. (2009). Pre-and post-urban wetland area in Dhaka City, Bangladesh: a remote sensing and GIS analysis. Journal of Water Resource and Protection, 1 (06), 414.

Tan, K. W. (2006). A greenway network for Singapore. Landscape and urban planning, 76(1-4), 45-66.

The Finger Plan, Ministry of the Environment, Denmark, 2015

Tng, S., \& Tan, S. (Eds.). (2012). Designing Our City: Planning for a Sustainable Singapore. Urban Development Authority.

Tran, T. D. B., Puissant, A., Badariotti, D., \& Weber, C. (2011). Optimizing spatial resolution of imagery for urban form detection-The cases of France and Vietnam. Remote Sensing, $3(10), 2128-2147$.

URA (Urban Redevelopment Authority) Singapore master plan 2008

Van den Dobbelsteen, A. N. D. Y., Tillie, N. I. C. O., Kürschner, J. U. L. I. A. N. E., Mantel, B., \& Hakvoort, L. A. U. R. A. (2011). The Amsterdam guide to energetic urban planning. In Management and Innovation for a Sustainable Built Environment; MISBE 201 1, (June 2023) CIB International Conference, Amsterdam. Delft University of Technology.

Weng, Q. (2012). Remote sensing of impervious surfaces in the urban areas:

Requirements, methods, and trends. Remote Sensing of Environment, 117, 34-49.

Wilson, J. S., Clay, M., Martin, E., Stuckey, D., \& Vedder-Risch, K. (2003). Evaluating environmental influences of zoning in urban ecosystems with remote sensing. Remote sensing of environment, 86(3), 303-321.

Wolfram, S. (2002). A new kind of science (Vol. 5, p. 130). Champaign, IL: Wolfram media.

Zhu, Z., Woodcock, C. E., Rogan, J., \& Kellndorfer, J. (2012). Assessment of spectral, polarimetric, temporal, and spatial dimensions for urban and peri-urban land cover classification using Landsat and SAR data. Remote Sensing of Environment, 117, 72-82. 